\title{
A INFLUÊNCIA DO REALISMO JURÍDICO NORTE-AMERICANO NO DIREITO CONSTITUCIONAL BRASILEIRO
}

\author{
Dissertação de Mestrado \\ Orientador - Professor Associado José Reinaldo de Lima Lopes \\ Candidato - Paulo Macedo Garcia Neto
}

Faculdade de Direito da Universidade de São Paulo

São Paulo - 2008 
"It is difficult to get a man to understand something when his salary depends on his not understanding it"

Upton Sinclair, The Jungle 
AGRADECIMENTOS 5

INTRODUÇÃO

CAPÍTULO I - ESTADO DA ARTE 17

MAPA BIBLIOGRÁFICO SOBRE O TEMA 17

CAPÍTULO II - A QUESTÃo SOCIAL NOS CONTEXTOS HISTÓRICOS NORTEAMERICANO E BRASILEIRO 27

CONTEXTO HISTÓRICO NORTE-AMERICANO 29

De Lochner V. NeW York a WeSt COAST Hotel Co. V. PARRISH 29

A COMPARAÇÃO ENTRE DIFERENTES LOCUS DE PODER 42

O Supremo Tribunal Federal e a Suprema Corte norte-americana ou o debate legislativo e doutrinário e a Suprema Corte norte-americana_ 42

Um Supremo Tribunal Federal (ou Corte Suprema) neutralizado 45

CONTEXTO HISTÓRICO BRASILEIRO 50

A questão social - O desenvolvimento industrial periférico brasileiro e a efervescência social - A regulação dos contratos de trabalho 52

Os "fins sociais" da Lei de Introdução ao Código Civil de 1942 - uma pequena resposta à ortodoxia-liberal do Código Civil de 1916 63

CAPÍTULO III - PROGRESSIVE LEGAL THOUGHT 67

A CRÍTICA AO CONCEITUALISMO JÚRIDICO NORTE-AMERICANO (CLASSICAL LEGAL THOUGHT OU MECHANICAL SCHOOL) - O PAPEL DE OLIVER WENDELl HOLMES JR. 75

A SOCIOLOGICAL JURISPRUDENCE E O REALISMO JURÍDICO NORTE-AMERICANO 79

CAPÍTULO IV - O REALISMO JURÍDICO BRASILEIRO 84

CRÍTICA ÀS IDÉIAS FORA DO LUGAR - O PAPEL DA INTERDISCIPLINARIEDADE 88

A crítica ao conceitualismo jurídico brasileiro de Rui Barbosa - O papel de Alberto Torres como precursor de um pensamento 90

O papel de Oliveira Vianna como crítico dos clãs sociais e da ausência de opinião pública 93 A CULTURA JURÍDICA E A QUESTÃo SOCIAL 98

Corporativismo e institucionalismo 100

O corporativismo, a questão social e os debates entre Oliveira Vianna e Waldemar Ferreira

O individualismo grupalista - L. Brandeis, O. Vianna e J. Mangabeira_ 106

NOVOS MÉTODOS DE DIREITO PÚBLICO (ANTICONCEITUALISMO) - A QUESTÃO SOCIAL E A INTERPRETAÇÃO JURÍDICA - CONTEÚDO E ESTRUTURA 116

A questão social e o "método jurídico" : direito público ou direito privado? 117

A hermenêutica jurídica de Oliveira Vianna e a crítica ao marginalismo político 120 
A síntese do debate sobre hermenêutica jurídica em torno da estrutura da questão social e “reprivatização” do debate sobre interpretação judicial ___ 121

Os novos modelos de interpretação judicial e os "fins sociais" da lei _ 124

O debate em torno da Lei de Introdução ao Código Civil e os "fins sociais” da lei__ 128

A BUROCRACIA ESTATAL E O ESTADO DE DIREITO (RULE OF LAW) __ 134

Novas expertises para a burocracia estatal___ 134

A reafirmação do Estado de Direito - a soberania do contencioso judicial__ 136

Contexto norte-americano ___ 137

Contexto brasileiro — 140

Roscoe Pound e Alípio Silveira - a condensação do diálogo entre Brasil e Estados Unidos sobre interpretação e desenho institucional___ 145

A QUEDA DO ESTAdo Novo E A ANTROPOFAGIA REALISTA __ 151

CONCLUSÃO — 153

BIBLIOGRAFIA___ 157

FONTES DE ÉPOCA____ 183

RESUMO _ 184

ABSTRACT — 186 


\section{AGRADECIMENTOS}

A dissertação de mestrado é o primeiro dentre muitos longos passos para o ingresso na vida acadêmica. Desse modo, aproveito esse momento para agradecer a todas as pessoas que fizeram parte desse importante e difícil passo inicial. Foram muitas as pessoas que me ajudaram. A todas elas agradeço sinceramente. Lembrarei aqui de alguns nomes, certo que esquecerei de muitos outros.

Ao meu orientador e amigo José Reinaldo de Lima Lopes, a quem devo agradecer pelo cultivo do que era apenas um olhar curioso sobre o direito e a história. A admiração e gratidão que tenho por José Reinaldo ultrapassa os limites de quaisquer linhas escritas. Após mais de cinco anos de convivência e aprendizado constante, posso dizer que fiz duas graduações distintas, uma na Faculdade de Direito da USP, outra com o Professor José Reinaldo de Lima Lopes.

Outros professores marcaram minha formação intelectual, dentre os quais faço um agradecimento especial a Virgílio Afonso da Silva, quem me faz acreditar ainda ser possível o ensino jurídico no Brasil e a Carlos Alberto de Salles, quem me apresentou a uma nova forma de olhar para as instituições do direito e para o processo civil. Agradeço também a Ronaldo Porto Macedo Jr. e a Maria Theresa Rocha de Assis Moura pelo modo gentil com que sempre me receberam e me aconselharam. A Virgílio Afonso da Silva e a Oscar Vilhena Vieira agradeço pelos significativos comentários, críticas e sugestões que fizeram no exame de qualificação deste trabalho.

Agradeço ao Desembargador Luiz Antonio de Godoy, ao Ministro Massami Uyeda e ao Ministro Ricardo Lewandowski. Nos gabinetes desses três Juízes aprendi o direito para além dos livros e das salas de aula.

Aos meus queridos amigos que me acompanham desde uma longa jornada, compartilhando os mesmos sonhos e desafios, com sempre sinceros incentivos e sempre sinceras críticas. Agradeço especialmente pelas últimas.

Inicio esse rol por Thomaz Pereira, Rafael Alves, Felipe de Paula e Régis Dudena, pessoas queridas que têm acompanhado, ainda que à distância, momentos cruciais de minha vida. Lista na qual incluo André Abbud, Pedro Abramovay, Gustavo Bambini, 
Roberta Alves Pachota, Igor Volpato Bedone, Daniel Carvalho, Guilherme Paiva, Ivo Corrêa, Leandro Galluzi, Marina Godoy, Catarina Barbieri, Daniela Gabbay, Joana Zylberstein, Davi Tangerino, Carlos Alberto Leitão, Octávio Orzari, Thiago Lobo, Rafael Queiroz, Thiago Acca, Estela Guerrine, Leandro Waldvogel, Michelle Machado, Viviane Sakata, Daniel Arbix, César Pizani, Melissa Mestriner, Kleber Tomas de Resende, Débora Kalman, Renato Floh, Maure Pessanha, Ticiane Nogueira, Paulo Gomes, Patrícia e Regina Kobayashi e Rui Sérgio Murrieta. Agradeço também a Maria Virgínia Mesquita, Andréa Slemian, Otávio Valério, Priscilla Privatto, Marcelo Behar, Artur Badin, Otávio Luiz Rodrigues, Fábio Galleza, L. Gustavo Nogueira e Patrícia Landis.

A André Abbud, Pedro Abramovay e Gustavo Bambini, além da sincera amizade, agradeço pela confiança que tiveram em meu trabalho, quando apenas o que tinha era o brilho nos olhos.

Sou muito grato aos meus conterrâneos, de São José do Rio Preto, a quem aproveito para me desculpar por minha longa ausência.

Agradeço à Susana Henriques da Costa, por sua compreensão, carinho e paciência em momentos em que poucos conseguiriam me suportar. Além disso, agradeço por sua preciosa ajuda na revisão deste trabalho.

Agradeço à Escola de Direito da Fundação Getúlio Vargas, de cujo projeto inicial tenho orgulho de ter participado, ainda como pesquisador júnior. Naquela Escola tive a oportunidade de conviver com pesquisadores e professores que me instigaram o gosto pela pesquisa acadêmica, dentre os quais destaco Jean Paul da Veiga Rocha, Conrado Hübner Mendes, Emerson Fabiane Ribeiro, Gabriela Nunes Ferreira, Diogo Coutinho, Airton Seelaender, Marcelo Neves, Flávia Scabin, Camila Duran, Mariana Macário, Mauricio Sakata, Priscila Speccie e Natasha Caccia.

Agradeço à Fundação de Amparo à Pesquisa do Estado de São Paulo que financiou, em passado recente, minha pesquisa de iniciação científica. Também agradeço à Faculdade de Direito da Universidade de São Paulo, pela qual, apesar de minhas permanentes críticas, tenho muito carinho e gratidão. 
Agradeço aos meus alunos da Unimonte/ Santos e da Processus/ Brasília, nas pessoas dos coordenadores desses cursos, Felipe Chiarello e Professor Jaci.

Agradeço ainda aos queridos Manoel Pereira Calças, Maria Amélia, Ruth e Matheus, sempre tão generosos comigo e com minha família.

Por fim, agradeço a minha família, tantas vezes trocada pelo trabalho, mas sempre presente nos momentos mais difíceis. A minha irmã, Marília, e aos meus pais, Paulo e Emília, agradeço por ter tanto a agredecer. 


\section{Ao meu avô, Paulo Macedo Garcia}




\section{INTRODUÇÃO}

O objetivo desta dissertação de mestrado é analisar a assimilação "antropofágica" 1 do debate jurídico norte-americano produzido em torno da questão social ${ }^{2}$ durante a Era Roosevelt (1933-1945) por parte do pensamento jurídico brasileiro produzido durante a Era Vargas (1930-1945).

Desse modo, embora o título deste trabalho seja A influência do realismo jurídico norte-americano no direito constitucional brasileiro, ao longo das pesquisas ficou evidente que não se tratou exatamente de uma recepção ${ }^{3}$ ou de um processo de influência e colonização intelectual de uma escola de pensamento do capitalismo desenvolvido sobre o

\footnotetext{
${ }^{1}$ A expressão "assimilação antropofágica" será utilizada em vários momentos do texto para explicar a forma como os juristas absorvem as teorias jurídicas de diferentes nacionalidades e vertentes para, então, produzir uma solução eclética para seus problemas. Trata-se de uma associação da expressão "antropofagia" utilizada pelo Movimento Modernista para explicar o seu projeto para a arte brasileira com o projeto dos juristas dos anos 1930. Essa associação foi feita pela primeira vez por José Reinaldo de Lima Lopes quando conversávamos sobre a elaboração de texto escrito em co-autoria Critical legal thought in the first half of the XX Century (the case of Brazil), ainda em fase de conclusão.
}

${ }^{2}$ A expressão "questão social" apareceu na terceira década do século XIX (CASTEL, 1998, p.30), tendo sido utilizada inicialmente para descrever a miséria/pauperismo da classe operária. No entanto, após a Primavera dos Povos, em 1948, passou a ter uma conotação neutra, sendo identificada com a forma como o pensamento conservador tratava os problemas envolvendo a classe operária. Autores revolucionários, como Karl Marx e Friederich Engels, que até então utilizavam a expressão, passaram a se referir aos problemas vividos pelos trabalhadores sob a ótica da "luta de classes" (BRANCO, 2006, p. 18). Há um debate contemporâneo entre alguns pensadores, dentre os quais se destacam Robert Castel e Pierre Rosanvallon, sobre a existência de uma nova questão social, mais identifcada com uma suposta sociedade pós-moderna. Esta dissertação não pretende adentrar esse debate, já bastante aprofundado pelos pensadores das diversas áreas das ciências humanas. Para que não reste dúvida ao leitor, utilizar-se-á, neste trabalho, a expressão no sentido empregado pelos juristas dos anos 1930, mais próximo ao sentido original do termo, ou seja, a designação do pauperismo das classes operárias frente à apropriação de sua força de trabalho pelo Capital ou como diria Viveiros de Castro, um jurista do período: "Questão Social, segundo o meu conceito, é a que estuda todos os problemas que interessam ao emprego da força-trabalho; e se propõe a estabelecer sobre bases justas e eqüitativas as relações entre o capital e o trabalho" (CASTRO, 1920, p. 49).

3 “Algumas conseqüências da adoção de uma perspectiva global e um conceito ampliado de lei são ilustradas pelo tópico de difusão de lei - algumas vezes referido como recepção, transplantes ou transposição. A difusão (sob rótulos diferentes) tem recebido muita atenção, principalmente nos longos debates entre Alan Watson e diversos dos principais pensadores, incluindo Otto Kahn-Freund, Lawerence Friedman, Pierre Legrand e Esin Orücü" (TWINING, 2007, p. 83 - tradução livre). "Some implications of adopting a global perspective and a broadned conception of law are illustrated by the topic of diffusion of law - sometimes referred to as reception, transplants, or transposition. Diffusion (under different labels) has been subject of much attention, notably in long-running debates between Alan Watson and a number of leading scholars, including Otto Kahn-Freund, Lawerence Friedman, Pierre Legrand, and Esin Orücü” (TWINING, 2007, p. 83 - original). 
capitalismo periférico. O que ocorreu, na verdade, foi uma espécie de "deglutição" das idéias que se formaram em um debate transnacional constituído no contexto de crise do capitalismo industrial do final da década de 1920 e que tinha como núcleo de pauta a questão social ${ }^{4}$.

Nesse período, a ortodoxia liberal apresentava sinais evidentes de que havia fracassado enquanto política de Estado. O capitalismo industrial e o modelo taylorista/fordista haviam acelerado o processo de ampliação da complexidade social. Ao lado da modernização estavam as externalidades negativas do crescimento econômico, em especial, os resultados perversos da exploração da mão-de-obra pelo capital.

No centro da crise do capitalismo mundial, o realismo jurídico ${ }^{5}$ norte-americano ${ }^{6}$ apresentava-se como uma resposta a um modelo jurídico formalista e legitimador do

4 Para uma visão geral desse fenômeno, conferir Paolo Grossi (2000), António Manuel Hespanha e, recentemente, Duncan Kennedy (KENNEDY, 2006, p. 37), que analisou o caráter global da questão social e sua integração com as críticas contra as medidas dedutivistas e individualistas do final do século XIX: "A segunda globalização teve início aproximadamente em 1900 e perdeu a sua força ao final da Segunda Guerra Mundial, mas influenciou fortemente o pensamento sobre as estratégias de desenvolvimento econômico tanto internacionais quanto do terceiro mundo até a década de 1960. O que estava globalizado naquela época era uma crítica da primeira globalização e um projeto de reconstrução. A crítica era a de que a corrente de pensamento européia do final do século XIX abusou da dedução no método jurídico e era 'individualista' no conteúdo jurídico. O slogan da segunda globalização foi 'o social', uma abstração que desempenhou o mesmo papel durante este período que será, diretamente e com falhas, ser elaborado pelo Classical Legal Thought" (KENNEDY, 2006, p. 37 - tradução livre)". "The second globalization began around 1900 and had spent its force by the end of WWII, but strongly influenced thinking both about the international and about third worl economic development strategies through the 1960s. What was globalized this time was a critique of the first globalization and a reconstruction project. The critique was that the late nineteenth-century European mainstream abused deduction in legal method and was 'individualist' in legal substance. The slogan of the second globalization was 'the social', an abstraction that played much the same role during this period that will, right, and fault played in CLT” (KENNEDY, 2006, p. 37 - original).

${ }^{5}$ Um limite que precisa ser apresentado refere-se a qual movimento do realismo jurídico pretende-se investigar. Esta dissertação concentrou-se no estudo do realismo jurídico norte-americano que se desenvolveu entre 1905 (Lochner decision) e o final da Segunda Grande Guerra (1945). Desse modo, não foi objeto dessa pesquisa o estudo sobre o realismo jurídico escandinavo de nomes como o do dinamarquês Alf Ross (1899-1979), que teve, a partir dos anos 70, especialmente em função de seu diálogo com a obra de Hans Kelsen (1881-1973), um relativo interesse por parte dos teóricos do direito brasileiro e de outros menos lidos no Brasil, como Axel Hägerström (1868-1939), Karl Olivercrona (1897-1980, Escola de Uppsala) e Alfred Naess (1877-1955).

6 Apesar da grande diversidade existente entre os realistas norte-americanos, é possível explicar esse movimento a partir de quatro fases: (i) a concepção instrumentalista ou funcionalista do direito, (ii) o caráter indeterminado das regras jurídicas, (iii) o behaviorismo ou comportamentalismo e (iv) o anticonceitualismo (BILLIER, 2005, p. 251/262). 
laissez-faire ${ }^{7}$ ou ortodoxia liberal. Com a crise de 1929 (crash da bolsa de New York) e a falência do liberalismo econômico, os juristas norte-americanos não só buscavam explicar a nova realidade, como também tentavam apresentar um projeto jurídico condizente com o novo contexto. Nas universidades (Roscoe Pound, 1870-1964, e Karl Nickerson Llewellyn, 1893-1962), na Suprema Corte (Benjamin Nathan Cardozo, 1870-1938, e Louis Dembitz Brandeis, 1856-1941) e no corpo burocrático do governo (1933-1945) Franklin Delano Roosevelt (1882-1945) (James MacCauley Landis, 1899-1964) eram produzidas, a partir de diálogos com a filosofia pragmatista e com os juristas de todas as partes do mundo, alternativas ao mecanicismo judicial e ao modelo liberal.

Na periferia do capitalismo mundial, os juristas brasileiros contestavam o modelo ortodoxo-liberal e buscavam desenvolver um projeto de modernização do país, ao mesmo tempo em que tentavam legitimar novos mecanismos de regulação da economia e das relações entre trabalhadores e empregadores. No corpo burocrático de Vargas (Oliveira Vianna, Francisco Campos e Francisco Sá Filho) e nas revistas e debates jurídicos (João Mangabeira e Alípio Silveira) questionava-se o liberalismo da República Velha (18891930) e se buscava, no mercado global de idéias, modelos institucionais que pudessem ser "antropofagizados", substituindo as "idéias fora do lugar" implantadas pelo bacharelismo utópico da República Velha. Era o momento de explicar o Brasil, encontrar o desenho institucional mais adequado à realidade nacional, construir uma opinião pública e descobrir as soluções para converter o "atraso" em modernização.

Mais do que um tema comum do debate transnacional, a questão social fez com que, nos principais palcos do debate jurídico dos dois países e, em especial, na Suprema Corte norte-americana e na doutrina jurídica brasileira, houvesse uma tentativa de revisão do próprio método jurídico, como uma forma de se adequar o direito a um novo quadro de relações do capitalismo industrial. Desse modo, não só se via a necessidade de implantação de um aparato jurídico apto a tratar a questão social (como a regulação das relações do trabalho), como também se observava a necessidade de se reconstruir a forma como se

\footnotetext{
${ }^{7}$ A definição de laissez-faire é particularmente difícil. Wanderley Guilherme dos Santos cita A.J.Taylor para indicar os limites do laissez-faire ou da ortodoxia liberal: "A.J.Taylor já havia apontado para a dificuldade de uma definição incontroversa da expressão ao mostrar como o que aparece para alguns como pratica laissezfairiana aparecerá para outros, precisamente, como ilegítima intervenção do Estado no ordenamento social" (SANTOS, 1999, p. 68).
} 
aplicava o direito. O modelo formalista e conceitualista que havia se consolidado sob uma perspectiva privatista e liberal (econômico, no sentido laissez-faire) durante o século XIX, mostrava-se ineficiente para atender as novas demandas da sociedade. Esse aspecto de integração entre a questão social e o antiformalismo é essencial para compreender o paralelo entre o pensamento jurídico norte-americano e brasileiro no período entre guerras, uma vez que é por meio desse eixo comum que se estabeleceram o principal canal de leitura antropofágica do pensamento jurídico norte-americano pelo brasileiro.

Durante esse período, o pensamento jurídico crítico norte-americano (Progressive Legal Thought) combatia tanto o mecanicismo judicial, como o laissez-faire da Suprema Corte do caso Lochner (1905). De modo semelhante, os juristas brasileiros criticavam tanto o formalismo, como o liberalismo econômico, que haviam sido dominantes na doutrina jurídica brasileira durante a República Velha. Assim, em ambos os casos, os juristas concluíram que, para reformular o conteúdo do direito, substituindo a ordem liberal por uma ordem social e promovendo garantias e direitos para os trabalhadores, teriam também que alterar a própria forma como o direito era pensado, interpretado e aplicado.

Nos Estados Unidos, essa reformulação esteve sempre em torno da Suprema Corte. Os mais de 30 anos que separaram o caso Lochner (1905) do caso Parrish (1937) foram marcados por um intenso debate sobre o modo como a interpretação judicial deveria ser feita, mas que tinha como pano de fundo a crise do liberalismo econômico e a necessidade de se redefinir as relações entre capital e trabalho. As críticas que tiveram como precursor Oliver Wendell Holmes (1841-1935), ministro da Suprema Corte durante o julgamento do caso Lochner, continuaram nos debates acadêmicos traçados entre Karl Llewellyn e Roscoe Pound, bem como nos votos de Benjamin Cardozo e Louis Brandeis na Suprema Corte.

No Brasil, o Supremo Tribunal Federal (ou Corte Suprema entre 1934 e 1937) não foi o centro dos debates sobre a reformulação jurídica. A instituição que havia surgido em 1890, pouco após a proclamação da República, ainda não havia se consolidado como uma instituição sólida, quando houve a Revolução (ou golpe) de 1930 e o pouco poder que havia acumulado foi neutralizado pelos decretos de Vargas em 1931. Desse modo, os debates jurídicos deram-se especialmente na doutrina jurídica, nas comissões nomeadas 
para formular projetos legislativos e nos órgãos administrativos vinculados ao Executivo, como o Ministério do Trabalho.

Além das diversas mudanças legislativas em torno da questão social, como a criação de leis de proteção ao trabalhador e assistência previdenciária, questionava-se o formalismo jurídico como uma forma de se legitimar o Estado Liberal. Assim como não se admitia mais que as relações de trabalho fossem reguladas por contratos de locação de serviço, também se questionava a compatibilidade dos "métodos de direito privado" de interpretação júridica até então existentes com a nova realidade. Portanto, da mesma forma que seria necessário preencher as lacunas de um Código Civil de 1916 que havia marginalizado a questão social, seria preciso conceber uma nova lei de interpretação ao Código Civil que fornecesse aos juízes um modelo de interpretação judicial compatível com os "novos tempos". O artigo 5. ' da Lei de Introdução ao Código Civil (LICC) de 1942 teria esse papel, determinando que a finalidade da adjudicação judicial fosse atender aos "fins sociais" da lei.

Nesse cenário, a construção de uma cultura jurídica ${ }^{8}$ crítica às premissas liberais, individualistas e formalistas da República Velha iniciou-se antes mesmo do fim da segunda década do século XX. O precursor de uma dessas linhas de pensamento, que fícou conhecida por autoritarismo instrumental ${ }^{9}$ e se situava à direita no pensamento político, foi

${ }^{8}$ Embora esta dissertação tenha como objetivo rever um debate de teoria do direito desenvolvido no Brasil até a primeira metade do século $\mathrm{XX}$, não se tem a pretensão de produzir, propriamente, um estudo de filosofia do direito, ou de direito constitucional ou de direito do trabalho. Desse modo, a interdisciplinaridade deste trabalho possui como marco delimitador a utilização de uma metodologia própria ao estudo da história do direito. Utilizar-se-á, assim, muito mais dos instrumentos de análise da historiografia jurídica do que da filosofia do direito. Dessa forma, pauta-se por uma abordagem da história do pensamento jurídico que leva em consideração o fato de que as transformações (análise das rupturas e continuidades presentes nesse processo) na cultura jurídica não ocorrem simplesmente com a mudança do texto da lei, mas se definem a partir da relação que se estabeleceu na prática judicial entre textos legais, categorias do pensamento jurídico e as condições sociais, políticas e institucionais. António Manuel Hespanha desenvolve quatro linhas de força que definem a história do direito: (i) ser mais que a história das leis; (ii) buscar o impacto de uma determinada produção doutrinal na vida jurídica de seu tempo, mais do que seu brilho ou originalidade; (iii) combate ao jurisdicismo, entendendo o direito como algo condicionado aos fatos sociais; e (iv) garantir a autonomia (embora relativa) da história das instituições jurídicas em relação à história social geral (HESPANHA, 1982, pp. 17-28).

${ }^{9}$ A expressão autoritarismo instrumental foi criada por Wanderley Guilherme dos Santos para denominar o grupo de autores brasileiros que acreditavam no papel do Estado como orientador do desenvolvimento da sociedade e viam no autoritarismo uma passagem transitória necessária para alcançar esse desenvolvimento. De acordo com esse cientista: "Dois aspectos distinguem o autoritarismo instrumental tanto dos liberais doutrinários quanto dos outros autoritários. Em primeiro lugar, os autoritários instrumentais (...) crêem que as sociedades não apresentam uma forma natural de desenvolvimento, seguindo antes os caminhos definidos e orientados pelos tomadores de decisão. E desta presunção deriva-se facilmente a inevitável intromissão do 


\begin{abstract}
Alberto Torres ${ }^{10}$ (1865-1917), cujas idéias foram retomadas por Francisco José de Oliveira Vianna $^{11}$ (1883-1951) e Francisco Campos ${ }^{12}$ (1891-1968), ambos membros da burocracia estatal e do núcleo formulador do estado autoritário do governo Vargas. No entanto, a crítica às premissas liberais, individualistas e formalistas da República Oligárquica não foram produzidas apenas por essa vertente do pensamento brasileiro. Juristas de oposição
\end{abstract}

Estado nos assuntos da sociedade, a fim de assegurar que as metas decididas pelos representantes desta sociedade sejam alcançadas. Nesta medida, é legítimo e adequado que o Estado regule e administre amplamente a vida social - ponto que, desde logo, os distingue dos liberais. Em segundo lugar, afirmam que o exercício autoritário do poder é a maneira mais rápida de se conseguir edificar uma sociedade liberal, após o que o caráter autoritário do Estado pode ser questionado e abolido. A percepção do autoritarismo, como um formato político transitório, estabelece a linha divisória entre o autoritarismo instrumental e as outras propostas políticas não democráticas” (SANTOS, 1978, pp. 102-103)

${ }^{10}$ Alberto Torres, que sucedeu a Antônio Gonçalves de Carvalho, chegou ao Supremo Tribunal com apenas 35 anos, o mínimo exigido pela Constituição, tomando posse em 18 de maio de 1901. O nascimento - filho de um magistrado e futuro senador da República - e o talento propiciaram-lhe uma rapidíssima carreira de deputado estadual a deputado federal, ministro da Justiça (aos 29 anos) e presidente do Estado do Rio de Janeiro (de 1897 a 1900)" (RODRIGUES, 1991, p. 38). "Um ex-deputado, ex-governador, ex-ministro da Justiça e ex-ministro do Supremo Tribunal Federal, Alberto Torres, comanda a corrente dos homens que perderam a fé na Carta de 1891. Quer, não reformá-la, mas transformá-la, seduzido por problemas novos, de ordem social e econômica" (FAORO, 2001, p. 750).

${ }^{11}$ Oliveira Vianna (1883-1951) nasceu no Estado do Rio de Janeiro, formou-se pela Faculdade de Direito do Rio de Janeiro, na qual foi professor. Não teve participação política ostensiva, mas formulou, após 1930, programas de revisão constitucional e o arcabouço da legislação trabalhista e sindical, na condição de consultor jurídico do Ministério do Trabalho.

12 Francisco Luís da Silva Campos nasceu em Dores do Indaiá (MG), em 1891. Bacharelou-se pela Faculdade Livre de Direito de Belo Horizonte, em 1914. "Em 1919, iniciou sua carreira política elegendo-se deputado estadual em Minas Gerais pela legenda do Partido Republicano Mineiro (PRM). Dois anos depois, chegou à Câmara Federal, reelegendo-se em 1924 (...). Em 1926, com a posse de Antônio Carlos no governo de Minas Gerais, assumiu a secretaria do Interior daquele estado (...). Em 1929, ao ficar clara a preferência do presidente da República Washington Luís pelo nome de um paulista para sucedê-lo no cargo, em detrimento da candidatura de Antônio Carlos, Campos foi encarregado por este último de negociar a articulação de uma candidatura oposicionista junto às forças políticas gaúchas. Nesse sentido, foi o representante mineiro na reunião realizada no Rio de Janeiro, em junho de 1929, que acertou o apoio de Minas a uma candidatura gaúcha à presidência da República, primeiro passo para o lançamento, tempos depois, do nome de Getúlio Vargas pela Aliança Liberal (...). Com a posse do novo regime, assumiu a direção do recém-criado Ministério da Educação e Saúde, credenciado por sua atuação à frente dos assuntos educacionais de Minas. Promoveu, então, a reforma do ensino secundário e universitário no país (...) Francisco Campos deixou o ministério em setembro de 1932 (...). Transferiu-se em seguida para o Rio de Janeiro, sendo nomeado consultor-geral da República, em novembro de 1933 (...). Nomeado ministro da Justiça dias antes do golpe, foi, então, encarregado por Vargas de elaborar a nova Constituição do país, marcada por características corporativistas e pela proeminência do poder central sobre os estados e do Poder Executivo sobre o Legislativo e o Judiciário. O período do Estado Novo foi marcado ainda pelo forte clima repressivo e pelas frequentes violações aos direitos individuais (...). Em 1964, participou das conspirações contra o governo do presidente João Goulart. Após a implantação do regime militar, voltou a colaborar na montagem de um arcabouço institucional autoritário para o país, participando da elaboração dos dois primeiros atos institucionais baixados pelo novo regime (AI-1 e AI-2) e enviando sugestões para a elaboração da Constituição de 1967”. Faleceu em Belo Horizonte, em 1968 (www.cpdoc.fgv.br). 
ao autoritarismo de Vargas, como João Mangabeira ${ }^{13}$ (1880-1964), e outros não relacionados ao governo, como Orlando Gomes (1909-1988), também se posicionaram contra o modelo privatista, liberal e individualista da República Velha.

Da mesma forma que a crítica ao individualismo e à ortodoxia liberal da República Velha provinha de pólos políticos diversos, a leitura dos realistas norte-americanos pode ser observada tanto (i) em juristas que apoiavam o governo ou faziam parte da burocracia estatal, como Francisco Campos e Oliveira Vianna, como também (ii) em agentes de oposição ao governo (1930-1945) Getúlio Dornelles Vargas (1882-1954), como João Mangabeira e (iii) em outros pensadores que, apesar de fazerem parte da burocracia estatal, não eram intransigentes apoiadores de Vargas, como Francisco Sá Filho ${ }^{14}$, bem como (iv) em autores dedicados ao estudo de hermenêutica/interpretação jurídica, como Eduardo

13 João Mangabeira formou-se em 1897, aos 17 anos de idade, pela Faculdade de Direito da Bahia. No mesmo ano, redigiu com Bernardino Madureira de Pinho um manifesto contra os degolamentos de Canudos. Em 1902, ingressou para o partido de oposição local de Ilhéus, fundando o jornal A Luta. Em 1906, foi eleito deputado estadual. De 1908 a 1911, exerceu a função de intendente (prefeito) de Ilhéus. Em 1908, foi eleito deputado federal. Em 1909, participou com Rui Barbosa da campanha civilista. Por indicação de Rui Barbosa, Mangabeira assumiu, em 1911, o posto de redator-chefe do Diário de Notícias. Na Câmara, pertencia à Comissão de Justiça e à Comissão Especial, relatando projetos como Banco Hipotecário e o Código Penal Militar. No Governo Arthur Bernardes, substituiu Herculano de Freitas, quando este foi nomeado ministro do Supremo Tribunal Federal. Em 1930, João Mangabeira foi nomeado pelo Governo provisório para compor a Comissão de Juristas do Itamaraty que redigiria o projeto de Constituição. Suas posições nessa comissão foram defendidas em uma série de artigos publicados no jornal Diário Carioca e, mais tarde, reunidos em seu livro Em torno da Constituição (LIMA, 1987, pp. 15-31). O fillho de João Mangabeira, Francisco Mangabeira foi um dos fundadores da Aliança Nacional Libertadora (ANL) e aos 25 anos de idade, durante a "Intentona Comunista", foi preso e exonerado do cargo de advogado da Caixa Econômica Federal. Em resposta, Mangabeira impetrou uma série de habeas-corpus em nome dos 92 presos políticos civis, dentre os quais estava seu filho (DULLES, 1985, p. 16). Todos foram denegados. Mais tarde, também preso pela declaração do estado de guerra em novembro de 1936, João Mangabeira impetrou habeas-corpus em seu favor e em favor do senador Abel Chermon e no dos deputados federais Abguar Bastos, Domingos Velasco e Otávio Silveira. O pedido de $n^{\circ} 26.178$ teve como relator o ministro Carvalho Mourão, julgado na sessão de 20 de julho de 1936. A ordem foi negada. (COSTA, 1964, p. 68-90). Em 1937, João Mangabeira foi condenado pelo Tribunal de Segurança Nacional. Impetrou habeas-corpus perante o Supremo Tribunal Militar, que foi concedido por unanimidade. Mangabeira ficara preso por 15 meses e dois dias. Em 1946, fundou a Esquerda Democrática, depois transformada em Partido Socialista Brasileiro. Foi relator da lei sindical em 1947 (LIMA, 1987, pp. 28-29).

${ }^{14}$ Francisco Sá Filho foi deputado e professor de Ciência das Finanças da Pontifícia Universidade Católica do Rio de Janeiro. Exerceu funções de oficial de gabinete do ministro da Agricultura, em 1914; do ministro da Fazenda, em 1915 e do ministro da Viação, em 1922. Em 1917, foi nomeado oficial e depois adjunto da Procuradoria-geral da Fazenda Pública. De 1939 a 1945, exerceu as funções de Procurador-geral da Fazenda Pública. Foi nomeado juiz do TSE em 1945. Dentre as suas principais obras estão $O$ Estado de Sitio e sua Regulamentação, Rio de Janeiro, Imprensa Oficial, 1928 e Pareceres da Procuradoria da Fazenda (dados coletados na página oficial do Ministério da Fazenda). 
Espínola (1875-1967) e Alípio Silveira ${ }^{15}$. No entanto, não há dúvida de que o autor brasileiro que mais se utilizou do realismo jurídico norte-americano foi Oliveira Vianna ${ }^{16}$. Por essa razão, embora Oliveira Vianna seja o principal autor dessa relação com o realismo jurídico norte-americano, ocupando, portanto, o papel de "autor-protagonista" nesta dissertação, analisarei as demais relações do pensamento jurídico brasileiro com o Progessive Legal Thought norte-americano (Sociological Jurisprudence e realismo jurídico).

Busco, assim, reconstruir parte do debate jurídico brasileiro da Era Vargas em torno da questão social, o que inclui tanto as propostas de reformulação do conteúdo do direito, como os projetos de transformação dos métodos de interpretação desse direito. Na constituição desse novo direito, parte da cultura jurídica brasileira utilizou-se do pensamento jurídico norte-americano (Progressive Legal Thought) que se formava em torno das mesmas questões nos Estados Unidos da Era FDR. Portanto, é o resultado dessa deglutição intelectual que será estudado e confrontado com o próprio pensamento jurídico norte-americano produzido durante o período entre guerras.

Para alcançar esse objetivo, iniciarei com (i) um mapeamento da literatura produzida sobre os juristas brasileiros da Era Vargas. Em seguida, (ii) descreverei os contextos históricos norte-americano e brasileiro, explorando os cenários políticos, econômicos e sociais dos dois países, com destaque para os eventos, manifestações políticas, transformações legislativas e jurisprudenciais que se produziram em torno da questão social. O próximo e último passo será (iii) analisar a cultura jurídica norteamericana e brasileira do período, definindo os termos da assimilação antropofágica brasileira.

\footnotetext{
15 Alípio Silveira, por exemplo, tem sua obra O Fator Político-Social na Interpretação das Leis (1946), prefaciada por ninguém mais, ninguém menos, que Roscoe Pound, o principal artífice da Sociological Jurisprudence.

${ }^{16}$ Em função de suas preocupações com a questão social e com a reformulação do pensamento júridico, a obra de Oliveira Vianna terá especial importância neste trabalho, sem que isso signifique deixar-se capturar pelas pautas do autor, que será apenas um dos autores estudados. Entendo que este foi um dos equívocos de Maria Lúcia de Paula Oliveira (OLIVEIRA 1995), que expôs o debate sobre a interpretação constitucional apenas pela ótica de Oliveira Vianna, não a confrontando nem com seus opositores nem com os autores norte-americanos que o influenciaram.
} 


\title{
CAPÍTULO I - ESTADO DA ARTE
}

\author{
“Imaginemos que as ciências naturais viessem a sofrer as conseqüências de \\ uma catástrofe. A opinião pública culpa os cientistas por uma série de \\ calamidades ambientais. Há revoltas por toda parte, laboratórios são \\ incendiados, cientistas são linchados, livros e instrumentos são destruídos. \\ Por fim, um movimento político chamado 'Nenhum Saber' assume o poder e, \\ sucessivamente, elimina o ensino de ciências nas escolas e nas universidades, \\ aprisionando e executando os cientistas restantes. Mais tarde há uma reação \\ contra esse movimento destrutivo e pessoas esclarecidas tentam ressuscitar a \\ ciência, embora tenham esquecido em grande parte o que ela tenha sido. Só \\ possuem, porém, fragmentos” (MACINTYRE, 2001, p. 13).
}

\section{MAPA BIBLIOGRÁFICO SOBRE O TEMA}

O debate jurídico é normalmente regido por “ondas” temáticas que se disseminam pela cultura jurídica de todo mundo. Interligados por uma série de redes econômicas, sociais, culturais e políticas que superam as fronteiras nacionais, os juristas são bombardeados por leituras de diferentes países e de diferentes vertentes. Muitas idéias de diferentes tendências são absorvidas e ecleticamente utilizadas na produção de um discurso jurídico, que, apesar de estar em sintonia com a "onda" temática global, possui suas características próprias e, muitas vezes, é elaborado com o objetivo de solucionar problemas locais/ nacionais. Com o passar do tempo, essas "ondas" temáticas são superadas e novos diálogos surgem. No entanto, as construções anteriores não se tornaram, por isso, inúteis. Estruturadas a partir da deglutição intelectual, são únicas e não se resumem às idéias dos autores e escolas que foram digeridos pela cultura jurídica local. $\mathrm{O}$ papel da história do direito é preservar essa produção, de tal modo que os novos diálogos globais sejam feitos a partir daquele ponto de partida. Nos países em que isso é levado a sério, é possível reconstruir os debates jurídicos nacionais, identificando-se tanto as escolas jurídicas como as possíveis soluções (ou mesmo fundamentos de legitimação do status quo) já pensadas para os problemas locais. Sem isso, os juristas inseridos nas novas “ondas" globais tornam-se apenas coadjuvantes no debate global, uma vez que nem foram 
capazes de construir escolas de pensamento, nem arquitetaram um discurso jurídico autêntico.

Uma demonstração disso é que o pensamento jurídico produzido durante a Era Roosevelt (FDR), nos Estados Unidos - o realismo jurídico - foi estudado sob os mais diferentes enfoques e visões. Isso permitiu que, no decorrer da história do pensamento jurídico norte-americano, tenha sido possível estabelecer linhas de seguidores (com continuidades e rupturas) e de opositores à herança realista. Por outro lado, pouco se sabe sobre o pensamento jurídico produzido durante a Era Vargas, no Brasil. Muitos desses autores foram demonizados pelos juristas, como é o caso de Alberto Torres, Oliveira Vianna $^{17}$ e Francisco Campos, outros foram esquecidos pela maior parte da doutrina jurídica contemporânea, como o congressista de oposição à Era Vargas, João Mangabeira; e outros são completamente desconhecidos por quase toda a atual geração de juristas vivos, como Alípio Silveira e Francisco Sá Filho.

${ }^{17}$ Embora eu pretenda estudar a obra desses autores demonizados pelas gerações que os sucederam, ressalto que este trabalho não busca, de modo algum reviver suas teorias. Ademais, em nenhum momento, desconsidera-se o conservadorismo e o autoritarismo defendidos por esses autores. No entanto, anoto que esse conservadorismo e, especialmente, as teorias racistas defendidas por Oliveira Vianna em Populações Meridionais do Brasil (1920), em Evolução do Povo Brasileiro (1923) e em Raça e Assimilação (1932), não serão profundamente analisadas nesta dissertação, uma vez que extrapolam o seu objeto. De todo o modo, faço uma pequena digressão quanto a esse tema para questionar o quanto esses aspectos da obra de Vianna foram sobrevalorizados, marginalizando e obscurecendo elementos importantes da obra desse autor, como a sua preocupação com os problemas de organização do Estado e da sociedade brasileira. Nesse sentido, acompanho Gildo Marçal Brandão: "O seu pé-de-chumbo seria, como se sabe, o extenso uso que fazia de teorias e argumentos racistas para avaliar o papel da mestiçagem e explicar a desigualdade social e política brasileira. Aspecto que lhe atraiu a artilharia de Sérgio Buarque de Holanda, Nélson Werneck Sodré, Dante Moreira Leite, José Honório Rodrigues, Vanilda Paiva e muitos outros, cada um ao seu modo batendo forte na concepção 'arianizante' e psicologizante da cultura brasileira esposada pelo autor, desqualificando os conhecimentos geográficos e históricos sobre os quais se assentava seu edifício teórico, horrorizando-se com sua 'apologia' do que então se chamava de 'latifúndio feudal' e protestando contra a crítica da democracia política que precedia sua defesa de um estado forte e autoritário. Independentemente do valor dessa linhagem, hoje francamente minoritária, pode-se dizer que ela concedeu mais atenção à sociologia do que a ciência política de Oliveira Vianna e apenas precariamente enfrentou os problemas de organização e direção da sociedade e do Estado que sua reflexão pretendia resolver. Ora, são estes que, jogadas no lixo as velharias racistas, preservam o interesse pelo texto; fazem que, com o distanciamento que o tempo permite, Populações Meridionais do Brasil possa figurar em uma estante selecionada ao lado de Casa-Grande $e$ Senzala, de Gilberto Freyre, Raízes do Brasil, de Sérgio Buarque de Holanda, e Formação do Brasil Contemporâneo, de Caio Prado Júnior, como um dos textos fundadores do que se convencionou chamar de 'pensamento político' ou 'pensamento social' brasileiro. E se chega a ser ridículo o esforço acadêmico recente para tapar o sol com a peneira e minimizar o fato de que a obra é 'cheia de preconceitos ideológicos' e de 'uma vontade excessiva de adaptar o real a desígnios convencionais', para usar os termos de Antônio Cândido, cabe reconhecer que tanto o retrato do Brasil como as teses políticas que emergem de suas páginas, põem o dedo em algumas feridas e constituem um desafio à teoria e à prática da contrução da democracia no país" (BRANDÃO, 2007, pp. 69-71). 
Assim, ao contrário de países como os Estados Unidos, que preservaram a história de seus debates jurídicos, tem sido difícil pensar o direito brasileiro a partir do discurso teórico dos juristas, uma vez que, "esquecidos" pelas gerações seguintes, perderam-se diante das "últimas novidades" trazidas pelos novos diálogos globais. Repleta de vícios como o "manualismo", o "referencialismo" (OLIVEIRA, 2004, p.6) e o "sincretismo metodológico" (SILVA, 2005, p. 133), a produção jurídica brasileira torna-se ainda mais desarticulada na medida em que se fragmenta historicamente sem criar traços de identidade ou ruptura com seu passado.

Portanto, elaborar um mapa da literatura que analisou o tema desta dissertação não é das tarefas mais fáceis, pois se trata de um debate "perdido" na tradição jurídica brasileira. Caberia a mim, então, primeiramente mostrar o que foi escrito sobre o pensamento jurídico brasileiro que se formou em torno da questão social durante a Era Vargas. Posteriormente, deveria encontrar autores que buscaram estabelecer relações entre o pensamento jurídico brasileiro que se formou durante a Era Vargas e o pensamento jurídico norte-americano produzido durante o governo Franklin Delano Roosevelt. Diante disso, recorri, em um primeiro momento, aos historiadores, sociólogos e cientistas políticos que analisaram a Era Vargas e, em um segundo momento, aos juristas que estudaram o período.

De um modo geral, pode-se dizer que a Era Vargas já foi bastante estudada pela historiografia e pela ciência política. No entanto, muitas questões ainda não foram solucionadas pelos pesquisadores. Em especial, os estudos que perpassam pelos temas do corporativismo de Estado e das suas intervenções nas relações industriais brasileiras são ainda bastante discutidos ${ }^{18}$. Muitos autores, dentre os quais Ângela Castro Gomes, Maria Helena Moreira Alves, Kenneth Mericle, Emília Viotti da Costa e, mais recentemente, John French, escreveram sobre essa temática.

18 O principal tema talvez seja a identificação de quais foram os verdadeiros agentes das mudanças legislativas em torno da questão social. Enquanto alguns defendem que o papel dos trabalhadores mobilizados teria sido essencial para as transformações do período, a maioria defende que as mudanças sociais teriam sido fruto de uma ação unilateral do Estado. Nesse sentido, French afirmou que: "Os problemas de categorização inadequada, conceitualização com falhas e imprecisão, que afetaram o crescente campo da história trabalhista da América Latina estão mais claramente ilustrados no debate sobre o significado da intervenção estatal nas relações industriais" (FRENCH, 1991, p. 1 - tradução livre). "The problems of miscategorization, faulty conceptualization, and imprecision, that plague the groing field of Latin America labor history are most clearly illustrated in the debate about the meaning of state intervention in industrial relations" (FRENCH, 1991, p. 1 - original). 
Poucos, no entanto, foram os autores da história e ciência política que estudaram a produção jurídica brasileira durante esse período. Em número ainda menor estão os pesquisadores que se dedicaram ao exame da relação da doutrina brasileira com o que se produzia no direito mundial. Mesmo assim, os poucos autores da história e da ciência política que estudaram esse tema o fizeram de modo bem mais profundo que os próprios juristas. O papel dos filósofos pragmatistas e do Progressive Movement norte-americano sobre a formação do pensamento de juristas brasileiros foi realizada, por exemplo, por Bolívar Lamonier, que discutiu essa relação na obra de Alberto Torres:

"Se fôssemos procurar uma inspiração gêmea à desse apóstolo do nacionalismo brasileiro, ela seria certamente o Progressive Movement do meio-oeste norte-americano no início deste século. O progressivismo, como Alberto Torres, almejava o fortalecimento do Estado, mas de um Estado neutro, administrativo, capaz de assegurar a competição entre produtores, se necessário através de uma estrita regulamentação da atividade das grandes empresas" (LAMONIER, 2006, p. 388).

Além de Bolívar Lamonier, Evaldo Vieira analisou o papel do realismo jurídico norte-americano na obra de juristas brasileiros. Em seu livro Autoritarismo $e$ Corporativismo no Brasil, cuja primeira edição foi publicada em 1976, Vieira dedicou um capítulo, "A concepção realista de mundo", para explicar a influência de autores como Louis Brandeis nos textos de Oliveira Vianna (VIEIRA, 1981, pp. 61-70).

Um autor que transita entre a ciência política e a história, José Murilo de Carvalho, analisou o papel que o realismo jurídico norte-americano exerceu de fato sobre alguns autores brasileiros. No caso de Oliveira Vianna, foram feitas algumas ponderações. José Murilo de Carvalho entende que as citações de outros autores por Vianna são apenas instrumentais e legitimadoras de suas idéias: 


\begin{abstract}
"Vários analistas salientaram a abundância de referências a autores estrangeiros na obra de Oliveira Vianna (...). Mas, aqui, novamente é preciso ter cautela quando se trata de interpretar o sentido dessas citações, de avaliar até que ponto elas representam influência real sobre seu pensamento. Os mesmos analistas já referidos chamaram a atenção para a maneira peculiar que Oliveira Vianna tinha de citar autores. Freqüentemente, pinçava pedaços da obra e desprezava outros, distorcendo o pensamento do autor, numa indicação clara do caráter instrumental ou mesmo ritual da citação. A citação de estrangeiros como ritual de legitimação era, aliás, uma prática generalizada no Brasil. O próprio Oliveira Vianna mencionou-a para explicar o êxito de Rui Barbosa e o fracasso de Alberto Torres. O primeiro citava torrencialmente, o segundo recusava-se a usar 'o bordão do autor estrangeiro'. Ninguém no Brasil dava crédito ao pensador nacional, por mais original que fosse. Tudo indica que não quis ter o destino de Alberto Torres" (CARVALHO, 1993, pp. 17-18).
\end{abstract}

Maria Lúcia de Paula Oliveira discorda de José Murilo de Carvalho. Segundo a autora, "por trás da citação de tais autores há algo mais que mera legitimação das idéias defendidas por Oliveira Vianna" (OLIVEIRA, 1995, p. 81). Nesse sentido, concordo com a autora, uma vez que, como se verá na sequiência deste trabalho, Oliveira Vianna partiu da crítica anticonceitualista dos autores realistas para construir sua crítica aos autores do liberalismo brasileiro. O mesmo foi feito por João Mangabeira.

Feita essa análise da literatura historiográfica e política da Era Vargas, cabe, agora, um exame do que foi dito pelos juristas sobre o tema. Enquanto na história e na ciência política é possível encontrar algumas análises mais profundas sobre o pensamento políticojurídico brasileiro que se formou durante a Era Vargas, no universo jurídico, esse exame foi quase sempre superficial, aproveitando-se de uma demonização fácil e simplificadora. Surge, então, um problema (digno de um modelo de ensino - e pesquisa - fragmentado em departamentos estanques e, por que não dizer, feudalizados): não houve um estudo no direito brasileiro que tratasse de modo integrado a questão social e o antiformalismo. Diante disso, a quais juristas eu deveria recorrer? De um lado, havia os especialistas em 
direito do trabalho. De outro lado, havia constitucionalistas. Por último, havia ainda os filósofos do direito. Diante desse quadro, organizei esses grupos de autores, na tentativa de mostrar quais são as peças que esta dissertação pretende preencher.

A história do direito do trabalho, disciplina que na Era Vargas era debatida por juristas das mais diversas áreas e hoje foi "departamentalizada", foi contada por Evaristo de Moraes Filho. Apesar de ter participado, como Secretário das Comissões Mistas de Conciliação, do Ministério do Trabalho, Indústria e Comércio, Rio de Janeiro (1934-1940), dos debates sobre a elaboração da legislação social e trabalhista, Evaristo de Moraes foi bastante crítico ao governo de Getúlio Vargas. De tendências socialistas, o autor considerava que a legislação social não foi simplesmente uma outorga do Estado, mas uma conquista dos trabalhadores. Em 1952, em seu livro Sindicato Único, Moraes Filho afirmaria que somente a partir das lutas e greves os trabalhadores teriam conquistado seus direitos. Desse modo, tais conquistas não teriam sido uma concessão unilateral do Estado (MORAES, 1952, p. 213). Em 1956, já professor livre-docente e catedrático interino de direito do trabalho da Faculdade Nacional de Direito da Universidade do Brasil, publicaria o seu livro mais famoso, Introdução ao Direito do Trabalho. Ainda na área de direito do trabalho, foi publicado, recentemente, um breve estudo sobre o papel da obra de Oliveira Vianna para a legislação trabalhista brasileira. O livro Oliveira Vianna e a Legislação do Trabalho no Brasil (2007), de autoria do juiz aposentado do Tribunal Regional do Trabalho do Espírito Santo, Hélio Mário de Arruda, reconstrói um pouco do mapa bibliográfico sobre a obra de Vianna.

Estudados os autores do direito do trabalho, passarei a rever o que foi produzido sobre o tema deste trabalho na área de direito constitucional. Os autores mais referenciados (clássicos) sobre a história/formação da Constituição Brasileira, como Waldemar Ferreira, José Afonso da Silva, Manoel Gonçalves Ferreira Filho, Paulo Bonavides e Afonso Arinos de Melo Franco, concentraram-se nos debates entre os paralamentares constituintes. E, ao analisar a história do pensamento jurídico constitucional brasileiro, a maior parte desses autores não examinaram o debate sobre o realismo jurídico no Brasil. Há, contudo, algumas referências às influências do realismo norte-americano sobre os autores do autoritarismo instrumental. Afonso Arinos, por exemplo, examinou a obra de Alberto Torres e criticou a forma como seu discípulo, Oliveira Vianna, conduziu suas análises: 
"Em certo sentido, Alberto Torres, apesar da indecisão e até da contradição sensível entre várias das suas teses e de um certo primarismo nas soluções, aventadas às vezes sem a técnica jurídica necessária, foi, sem dúvida, o primeiro pensador brasileiro republicano que, no campo político-social, colocou em foco certos problemas que o futuro próximo iria ser forçado a equacionar. $\mathrm{O}$ fato mesmo de ser um pensador até certo ponto isolado, sem antecessores nem sucessores que propiciassem uma sequiência sistemáticas de suas idéias (o seu discípulo mais autorizado, Oliveira Vianna, além de conduzir a obra em outros rumos, predominantemente históricos, obstinou-se na defesa de soluções jurídicas irrealistas, que contrariavam a evolução da nossa História), fez com que as teses fundamentais de Alberto Torres não pudessem ser mais bem desenvolvidas e transformadas em fórmulas capazes de servir de base à ação legislativa posterior" (FRANCO, 1960, p. 151).

Desse modo, a opinião de Afonso Arinos era a de que Alberto Torres não havia deixado um legado jurídico. Entendeu, assim, que as críticas de A. Torres à ortodoxia liberal da Primeira República não haviam tido qualquer reflexo sobre as gerações de juristas que o sucederam, estendendo essa avaliação a Oliveira Vianna, o que, no entanto, parece contraditório, na medida que identifica uma relação de continuidade entre esses dois autores.

Dentre os autores clássicos de direito constitucional brasileiro, o único que parece ter se dedicado a uma análise mais detida sobre a história do pensamento jurídico constitucional, traçando alguns fios condutores sobre as influências do realismo norteamericano e, ainda assim, sobre a obra de Oliveira Vianna foi Meirelles Teixeira, professor de direito constitucional da Faculdade de Direito da Pontifícia Universidade Católica de São Paulo (PUC/SP). Realço a cátedra à qual o professor Teixeira estava vinculado, porque ele não era professor da Faculdade de Direito da Universidade de São Paulo, escola de onde saíram os autores criticados por Oliveira Vianna e também seus maiores críticos, dentre os quais estão Pedro Lessa e Waldemar Ferreira. A relação conflitiva desses juristas 
identificados por Vianna como liberais e o autor fluminense parece ter sido determinante na produção científico-jurídica da Faculdade de Direito da Universidade de São Paulo. Praticamente não houve estudos sobre os juristas dos anos 1930 produzidos nessa escola. O mesmo já havia ocorrido com Alberto Torres, outro autor fluminense. Parece que o "Movimento Constitucionalista de 1932" deixou mais raízes na Faculdade de Direito do Largo de São Francisco que as placas ou o monumento em homenagem aos soldados constitucionalistas das Arcadas.

$\mathrm{Na}$ verdade, de um modo geral, os estudos desenvolvidos por juristas sobre os autores da Era Vargas são poucos e quase sempre realizados por professores e pesquisadores do Rio de Janeiro. Na Faculdade de Direito da Pontifícia Universidade Católica do Rio de Janeiro (PUC/RJ), Maria Lúcia de Paula Oliveira escreveu dissertação de mestrado sobre a invocação do Realismo Jurídico norte-americano e sua contribuição para a edificação do poder normativo da Justiça do Trabalho (OLIVEIRA, 1995). No entanto, Paula Oliveira parece ter se deixado capturar pelo olhar de Oliveira Vianna. Não há em sua dissertação nem um estudo sobre o realismo norte-americano, nem um diálogo com os interlocutores de Vianna.

Contudo, a escassez de estudos sobre os constitucionalistas brasileiros dos anos 1930 que participaram do debate sobre a questão social e utilizaram o realismo jurídico na construção de seu discurso não se restringe apenas àqueles que compuseram o corpo burocrático de Vargas, como Oliveira Vianna e Francisco Campos. Também há poucas análises sobre autores de oposição ao governo, como João Mangabeira. Os únicos que se dedicaram ao fundador do Partido Socialista Brasileiro foram Hermes Lima e Francisco Barbosa. Este último publicou, em 1987, o livro Idéias Políticas de João Mangabeira, texto que reunia artigos e discursos de João Mangabeira e que era apresentado ao leitor em introdução redigida por Hermes Lima (LIMA, 1987).

Há ainda os autores que analisaram o realismo jurídico norte-americano, dentre os quais se destaca Oscar Vilhena Vieira (A Moralidade da Constituição e os Limites da Empreitada Interpretativa, ou entre Beethoven e Bernstein). Além de Oscar Vilhena, Ana Lúcia Nina Bernardes Martins e José Ribas Vieira (Temas de Direito Constitucional Norte-americano) também estudaram o realismo norte-americano. No entanto, esses 
autores não examinaram as leituras que foram feitas do realismo jurídico norte-americano pelo pensamento jurídico brasileiro.

De outro lado, os autores da filosofia do direito dedicaram-se ao estudo das teorias filosóficas sobre os sentidos da interpretação e os métodos da hermenêutica jurídica. Os poucos autores que analisaram a história da interpretação jurídica no Brasil passaram ao largo do discurso realista no Brasil. No entanto, há freqüentes alusões à Escola de Direito Livre de François Gény que teria influenciado os realistas norte-americanos. Há também menções à obra de Alípio Silveira e o fator político-social na interpretação das leis, que teria sido influenciado tanto por Gény como pela sociological jurisprudence de Roscoe Pound. Dentre os autores que mencionam a obra de Alípio Silveira estão Christiano José de Andrade (Hermenêutica Jurídica no Brasil), Mário Franzen de Lima (Da Interpretação Jurídica) e Nelson Saldanha (Ordem Hermenêutica).

De um modo geral, portanto, os juristas ou ignoram os autores da Era Vargas ou tendem a associar esse pensamento jurídico com uma espécie de legitimação de uma transposição do modelo fascista de Estado para o lado de cá do oceano Atlântico. O corpo burocrático de Vargas, e, em especial, Oliveira Vianna e Francisco Campos, seriam os agentes intelectuais que teriam pensado o transplante do corporativismo de Mussolini. Nem mesmo o texto de Alfredo Bosi, A Arqueologia do Estado-Providência, em que o autor buscou demonstrar como o positivismo absorvido pelos políticos gaúchos e a própria Constituição do Estado do Rio Grande do Sul teriam exercido mais influência sobre o Estado corporativista de Vargas que o fascismo italiano, parece ter sido lido pela maioria dos juristas brasileiros.

É verdade que os doutrinadores brasileiros também liam os autores do corporativismo italiano, assim como muitas outras correntes que percorriam o mercado global de idéias. Os juristas liam-se e influenciavam-se. Os norte-americanos também não liam somente a si mesmos. Liam de François Gény aos italianos defensores de Benito Mussolini (1883-1945), passando pelos argentinos e muitos outros. O mesmo ocorria com os juristas brasileiros. Não havia a world wide web (Internet), mas as idéias jurídicas eram globalizadas e difundidas dentre as mais diferentes ideologias e regimes de governo. 
Desse modo, se a questão social era o grande tema dos anos 1930 em todo mundo ocidental industrializado ou em processo de industrialização, é no mínimo curioso que a questão social da década de 1930, no Brasil, teria sido quase sempre apenas relacionada ao fascismo italiano. Não que os italianos não tenham de algum modo influenciado o Brasil. O problema é que eles não foram os únicos. As externalidades negativas do capitalismo industrial (Taylorismo e Fordismo) afetavam quase todo o lado ocidental do globo e a regulação das relações entre empregadores e empregados também era uma pauta global. Assim, da mesma forma que não houve uma relação de causa e efeito entre os realistas norte-americanos e a legislação social brasileira, também não é adequado fazer uma simples identificação dessa legislação e da Era Vargas como um subproduto do nazifascismo, como tem sido feito pela doutrina jurídica brasileira.

A partir dessa releitura bibliográfica, conclui-se que não houve ainda um estudo das rupturas e continuidades presentes nas muitas mudanças ocorridas na teoria do direito brasileiro. Essas lacunas tornam-se ainda mais problemáticas em perídos da história marcados pela obscuridade do autoritarismo, como é o caso da Era Vargas, perdendo-se em meio ao imenso labirinto conceitual da doutrina jurídica brasileira, que tende a prestigiar o discurso "vencedor" e relegar ao "ostracismo intelectual" o discurso "vencido".

Busco, portanto, reconstruir alguns desses fragmentos perdidos da história do direito brasileiro, mesmo que muitos desses remendos permaneçam aparentes aos olhos do jurista de hoje, uma vez que fazem parte da colcha de retalhos de um ecletismo próprio da cultura jurídica. 


\section{CAPÍTULO II - A QUESTÃO SOCIAL NOS CONTEXTOS HISTÓRICOS NORTE-AMERICANO E BRASILEIRO}

A questão social era o problema que instigava a reflexão da burocracia estatal de todos os países que haviam iniciado o processo de industrialização. Esse fenômeno ampliava-se na medida em que era lançada a segunda revolução industrial com o modelo taylorista/fordista de produção e a questão social passava a ser percebida como uma externalidade negativa desse processo. Apesar de terem obtido resultados políticos bastante distintos do ponto de vista da preservação do Estado democrático de direito, tanto a Era $\operatorname{Vargas}^{19}$ quanto o New Deal, significaram o fortalecimento da proteção social e da regulação da economia e da relação entre indústria e trabalho.

Para compreender como Estados Unidos e Brasil trataram da questão social no cenário dos anos 1930, é preciso entender o contexto histórico vivido por esses países durante tal período. É este o próximo passo deste trabalho. Iniciarei pela contextualização histórica norte-americana sobre a questão social, passando em seguida ao estudo dos anos 1930 no Brasil e aos processos que conduziram ao fortalecimento da questão social no país.

Como explicarei ao longo desse capítulo, foi necessário fazer uma abordagem distinta sobre os dois países, uma vez que, não somente se referem à desenhos institucionais diversos, como também tiveram locus distintos de debate. Enquanto nos Estados Unidos a maior parte da produção jurídica formou-se (e continua se formando) em torno da Suprema Corte, no Brasil, a produção jurídica passou (e ainda passa) ao largo das decisões dos juízes e tribunais. Desse modo, na análise sobre o contexto histórico norte-

${ }^{19}$ A Era Vargas foi um período em que ocorreram transformações fundamentais no ordenamento jurídico brasileiro. A centralização da legislação processual (Código de Processo Civil de 1939 e Código de Processo Penal de 1941 - Decreto-lei $n^{\circ 0} 3.689$, de 3 de outubro de 1941), antes delegada aos Estados pela Constituição de 1891, a criação de uma legislação social, a instituição do voto feminino, a organização da burocracia governamental com a criação do Departamento de Administração do Serviço Público (DASP), a criação da Lei de Falências (Decreto-lei ${ }^{\circ}$ 7.661, de 21 de junho de 1945), mudanças da legislação penal (inserção das medidas de segurança do Código Penal de 1940), a regulação da Indústria e das relações entre empregadores e empregados (Decreto $n^{\circ} 5.452 / 1943$, a CLT), a edição da Lei de Interpretação ao Código Civil (LICC de 1942), base da interpretação de todo o ordenamento jurídico brasileiro até hoje, foram apenas algumas das reformas instituídas pelo governo e pela ditadura Vargas. 
americano, privilegiarei o estudo sobre como a Suprema Corte mudou sua forma de avaliar a questão social no decorrer das primeiras décadas do século XX. Já no estudo sobre o contexto histórico brasileiro, privilegiarei o processo legislativo em torno da questão social, o que inclui tanto as mudanças na legislação de proteção ao trabalhador, como as transformações que visavam combater o formalismo jurídico, visto pelos juristas da época como elemento da preservação do individualismo da República Velha. No entanto, nos dois casos, ao mesmo passo em que serão estudadas as mudanças operadas pelos "homens da lei" (juízes, agentes da burocracia estatal, representantes parlamentares, membros das comissões legislativas), também serão examinados os movimentos populares mobilizados em torno da questão social. 


\title{
CONTEXTO HISTÓRICO NORTE-AMERICANO
}

\author{
"What happens to a dream deferred? \\ Does it dry up \\ like a raisin in the sun? \\ Or faster like a score- \\ And them run? \\ Does it stink like rotten meat? \\ Or crust and sugar over- \\ like a syrupy sweet? \\ Maybe it just sags like a heavy load. \\ Or does it explode? \\ (Langston Hughes, “Lenox Avenue Mural, 1930)
}

\section{DE LOCHNER V. NEW YORK A WEST COAST HOTEL CO. V. PARRISH}

A história do debate jurídico norte-americano em torno da questão social pode ser dividida por algumas decisões da Suprema Corte. Dois precedentes, em especial, são importantes para explicá-la. Um deles é Lochner decision (Lochner v. New York), de 1905, cuja reação gerou o que Roscoe Pound (Liberty of contract - 1909) chamaria de sociological jurisprudence. Outro é o West Coast Hotel Co. v. Parrish, que definiu a constitucionalidade do segundo New Deal (1937) e a legislação emergencial com programas ampliados de assistência social, reforma sindical e previdenciária aplicada no governo de Franklin Delano Roosevelt (FDR) em resposta à crise econômica de $1929^{20}$.

${ }^{20}$ Quando John Maynard Keynes publicou The General Theory of Employment, Interest and Money (KEYNES, 1936) durante a Grande Depressão, e mesmo duas décadas após a Segunda Guerra Mundial, o problema econômico fundamental era compensar as poupanças e, desse modo, manter o nível de produção e renda. "A poupança das empresas caiu de 11,2 bilhões de dólares em 1929 para 3,2 bilhões de dólares em 1933, o pior ano da Grande Depressão, e só em 1941 é que reconquistou seu nível de antes da depressão. Em 1932 e 1933, as poupanças das pessoas físicas foram negativas, o que significa que estas, no todo, aumentaram sua dívida" (GALBRAITH, 1982, p. 45). 
Entre 1895 e 1937, a Suprema Corte norte-americana exerceu um papel que ficou conhecido por "doutrina da supremacia judiciária" ${ }^{21}$ (SCHWARTZ, 1966, p. 257). Tratava-se de um período de defesa da ortodoxia-liberal como política de Estado. A partir de 1937, entretanto, a Suprema Corte norte-americana passou a exercer um papel de autorestrição, sendo deferente na execução de políticas reguladoras.

Não se pode dizer, contudo, que durante todos esses anos (1895 a 1937) a Suprema Corte teria sido absolutamente contrária às legislações intervencionistas. Nesse longo período, medidas que tiveram reflexos na intervenção do Estado sobre o domínio econômico, como o Sherman Anti-trust Act (1890) e o Bankrupt Act (1934), foram declaradas constitucionais pela Suprema Corte. De qualquer modo, é a partir de 1937 que um "Estado ativista e regulador é definitivamente aceito como realidade constitucional indiscutível" 22 (ACKERMAN, 2006, p. 54).

No entanto, o que se pode dizer de modo absoluto é que, nesse período que antecedeu o segundo New Deal, a Suprema Corte adotou uma postura claramente antisocial. O caso mais representativo dessa postura da Suprema Corte foi o de Lochner $v$. New York. Nesse caso, estava em debate a constitucionalidade de um estatuto de New York que fixava um limite de horas de trabalho para os padeiros (jornada de trabalho de dez horas).

A desigualdade e a miséria intensificadas pelos processos de crescimento econômico e de urbanização no período 1900-1920 provocaram um acirramento dos conflitos sociais. Além disso, impulsionaram o surgimento de uma série de movimentos críticos na sociedade norte-americana que se manifestaram por meio de associações

\footnotetext{
${ }^{21}$ Em 13 de fevereiro de 1925, quando era Chief-Justice William Howard Taft, foi aprovada a Lei Judiciária, que restringiu a jurisdição obrigatória da Suprema Corte e criou a certiorari, ampliando sua jurisdição discricionária (RODRIGUES, 1992, p. 99).

${ }^{22}$ De acordo com Bruce Ackerman: "todos nós vivemos na era moderna que se inicia com o momento de transformação da Suprema Corte, em 1937, na qual um Estado Ativista e regulador é finalmente aceito como realidade constitucional indiscutível. Seria um dos maiores insultos, para um juiz moderno, acusá-lo de cometer o pecado original cometido pela Corte da era anterior ao New Deal, em casos, como, por exemplo, o de Lockner v. New York (...). O que importa, na verdade, não é o diagnóstico competitivo, mas o reconhecimento universal de que o universo constitucional antes da era Roosvelt era extremamente diferente do atual" (ACKERMAN, 2006, p. 54).
} 
sindicais (ex. Industrial Workers of the $W_{\text {orld }}^{23}$ ), correntes intelectuais, movimentos políticos (ex. o Partido Socialista da América - PSA, o jornalista John Reed - cronista da Revolução Russa -, a comunidade gay e os movimentos feministas ${ }^{24}$ de Greenwich Village, em New York) e novas tendências culturais (ex. na música, jazz e blues; na literatura, Upton Sinclair, que publicou, em 1906, The Jungle ${ }^{25}$; na dança, Isadora Duncan; e, na dramaturgia, Eugene O’Neal) (PURDY, 2007, pp. 185-192). Em New York, os novos imigrantes foram trabalhar em docerias ${ }^{26}$ e padarias. Em agosto de 1905, o New York Tribune relatou que uma greve na padaria Federman, no baixo East Side, transformou-se em um conflito violento quando os trabalhadores grevistas foram substituídos por outros $(\text { scabs })^{27}$ (ZINN, 2005, p. 324). ${ }^{23}$ Em 1905, 200 operários, de diferentes vertentes (socialistas, anarquistas e sindicalistas radicais), reuniram-
se em Chicago para fundar a Industrial Workers of the World (IWW), uma alternativa ao sindicalismo
conservador da AFL (American Federation of Labor), criado em 1886, como um conjunto de sindicatos
independentes. Os wobbies, como eram chamados os membros da IWW, negavam os instrumentos negociais
das relações de trabalho institucionalizadas, defendendo que as greves, manifestações, mobilizações e
ocupações eram mecanismos mais eficientes de luta por direitos do que as negociações contratuais. Os
wobbies organizaram estivadores, mineiros e operários, criando uma cultura de movimento com formas
originais de manifestação (literatura, teatro, slogans e canções como o hino "Solidariedade para Sempre").
Foram responsáveis por algumas das mais importantes greves da história norte-americana, como a de 1912,
em Lawrence, Massachusetts, realizada em fábricas têxteis controladas pelo banqueiro J. P. Morgan,
mobilizando 50 mil pessoas com o slogan "Nós queremos pão e rosas" (PURDY, 2007, p. 185: ZINN, 2005,
pp. 328-357; MAUK, 2005, p. 225).

${ }^{24}$ Sob a liderança de Anna Howard Shaw e Carrie Chipman Catt, a Associação Nacional de Sufrágio para as mulheres (NAWSA) conseguiu reunir dois milhões de membros em 1917 (PURDY, 2007, p. 188).

${ }^{25} \mathrm{O}$ romance que criticava as indignas condições de trabalho nos matadouros de Chicago foi lançado originalmente em um jornal socialista, Appeal to Reason, e influenciou outros escritores como Jack London, autor de People of the Abyss (ZINN, 2005, p. 322 - tradução livre).

${ }^{26}$ O poeta Edwin Markham escreveu, em janeiro de 1907, na revista Cosmopolitan, sobre as condições de trabalho dessas docerias: 'Em salas abafadas, mães e pais costuram dia e noite. Os que estão nas 'sweatshop' (fábricas com condições de trabalho abusivas) domésticas devem trabalhar por um valor mais baixo do que os que estão na 'sweatshop' de fábrica... e as crianças são tiradas de suas brincadeiras para dirigir e trabalhar como escravas junto aos seus pais... todo ano em Nova York e em outras cidades você pode ver crianças saindo e entrando destas casas deploráveis... não é uma civilização cruel a que permite que pequenos corações e pequenos ombros fiquem extenuados sob estas responsabilidades de adulto, enquanto que na mesma cidade um cão vira-lata esteja coberto de jóias e seja mimado e levado para passear no colo de veludo de uma fina dama nos maravilhosos boulevards?" (ZINN, 2005, p. 324 - tradução livre). "In unaired rooms, mothers and fathers sew by day and by night. Those in the home sweatshop must work cheaper than those in the factory sweatshops (...) And the children are called in from play to drive and drudge beside their elders (...) All the year in New York and in other cities you may watch children radiating to and from such pitiful homes (...) Is it not a cruel civilization that allows little hearts and little shoulders to strain under these grown-up responsabilities, while in the same city, a pet cur is jeweled and pampered and aired on a fine lady's velvet lap on the beautiful boulevards?" (ZINN, 2005, p. 324 - original).

27 “Os grevistas ou seus simpatizantes destruíram a padaria de Philip Federman em $\mathrm{N}^{\circ} 183$ Orchard Street no início da noite passada ao meio de cenas de grande tumulto. Os policiais golpeavam cabeças a torto e a 
As mobilizações sociais, no entanto, não foram capazes de impor, naquele momento, um ritmo de transformações que sensibilizasse o órgão responsável por conservar os valores da Fundação norte-americana (como se pensava ser o laissez-faire): a Suprema Corte. A lei que regulamentava o limite de horas de trabalho foi considerada inconstitucional pela Suprema Corte, sob o fundamento de que violaria as disposições da Emenda $\mathrm{XIV}^{28}$, segundo a qual ninguém pode ser privado do direito à vida, à liberdade ou à propriedade sem um devido processo legal. De acordo com o acórdão do caso Lochner ${ }^{29}$ :

\begin{abstract}
"Esse estatuto interfere no direito de liberdade contratual entre o empregador e os empregado, no que concerne ao número de horas durante as quais estes devem trabalhar na padaria do empregador. $\mathrm{O}$ direito de contratar quanto às atividades profissionais é parte do direito à liberdade individual protegido pela Emenda XIV [...]. De acordo com essa emenda, o Estado não pode privar ninguém de seu direito à vida, à liberdade ou à propriedade sem um devido processo legal. $\mathrm{O}$ direito de comprar ou vender trabalho é parte da liberdade protegida por essa emenda" (198 U.S., p. 53).
\end{abstract}

O único voto dissonante havia sido o do ministro Oliver Wendell Holmes. De acordo com o ministro Holmes, "A finalidade da Constituição não é tratar de qualquer

direito com seus cassetetes após dois dentre eles terem sido atacados pela turba..." (ZINN, 2005, 325 tradução livre). "Strikers or their sympathizers wrecked the bake shop of Philip Federman at No. 183 Orchard Street early last night amid scenes of the most tulmutuous excitement. Policemen smashed heads right and left with their nightsticks after two of their number had been roughly dealt with by the mob (...)" (ZINN, 2005, 325).

${ }^{28}$ Emenda XIV. Seção I. "Todas as pessoas nascidas ou naturalizadas nos Estados Unidos e sujeitas à sua jurisdição são cidadãs dos Estados Unidos e dos Estados em que residem. Nenhum Estado fará ou executará qualquer lei restringindo os privilégios ou imunidades dos cidadãos dos Estados Unidos; nem privará qualquer pessoa da vida, liberdade ou propriedade sem processo legal regular (due process of law); nem negará a qualquer pessoa dentro de sua jurisdição a igual proteção das leis" (CORWIN, 1986, p. 381). Amendment XIV. Section I. "All persons born or naturalized in the United States and subject to the jurisdiction thereof, are citizens of the United States and of the State wherein they reside. No States hall make or enforce any law which shall abridge the privileges or immunities of citizens of the United States; nor shall any State deprive any person of life, liberty, or property, without due process of law; nor deny to any person within its justification the equal protection of the laws".

${ }^{29}$ Outro caso simbólico desse período foi Coppage v. Kansas (1915) 236 U.S. 45. 
teoria econômica em especial" ${ }^{30}$. A teoria do devido processo legal substantivo ${ }^{31}$ (VILHENA, 2006, p. 478), porém, havia prevalecido, bloqueando a legislação social e servindo como paradigma para os 30 anos que se seguiriam. O voto divergente de Holmes, no entanto, seria utilizado como uma espécie de bandeira para a crítica contra a ortodoxia liberal e contra o conceitualismo jurídico.

Essa crítica ao liberalismo econômico não se circunscrevia apenas às posições adotadas pela Suprema Corte ou aos Estados Unidos. Nesse período, em todo mundo, começavam a surgir reações à ortodoxia liberal, ao mesmo tempo em que crescia a preocupação dos governos em torno da questão social. As burocracias e os juristas de diversas nações começavam a pensar soluções para a questão social. Havia uma intensa correspondência internacional entre os ministérios do trabalho (labor and home ministries) de diferentes países, bem como entre pareceristas, professores (acadêmicos ${ }^{32}$ ) e advogados trabalhistas, estabelecendo-se um debate internacional, cuja pauta era a comparação entre as políticas de organização e reforma social e trabalhista.

Uma demonstração disso é que, em 1908, quando Louis D. Brandeis, futuro ministro da Suprema Corte, atuou como advogado no caso Muller v. Oregon (1908), defendendo a constitucionalidade da regulação das horas e condições de trabalho das mulheres, estabeleceu uma série de comparações entre diferentes modelos de regulação das relações de trabalho. Para a elaboração de seu parecer (que, de acordo com a característica de Brandeis, não só continha argumentos jurídicos, mas evidências históricas, sociológicas e econômicas), Brandeis contou com a ajuda de Josephine Goldmark e Florence Kelley,

${ }^{30}$ Lochner v. New York, 198 U.S. 45, 75 (1905) (voto divergente).

${ }^{31}$ De acordo com Oscar Vilhena Vieira, o caso Lochner teria fundado o conceito de "devido processo legal substantivo": "Percebe-se, aqui, que a cláusula do devido processo legal não está sendo empregada apenas para assegurar à parte em processo judicial o direito de ser julgada de forma imparcial. A Suprema Corte também não está apenas policiando os demais Poderes para que não ultrapassem as competências que lhes foram conferidas pela Constituição, como no caso Madison vs. Marbury. O que temos em Lochner é o Tribunal verificando se a substância de uma lei, devidamente processada pelo Parlamento, ofende, ou não, valores substantivos protegidos pela Constituição. Ao se lançar nesta nova empreitada, a Corte funda o conceito de devido processo legal substantivo. A utilização de critérios substantivos por parte do Judiciário para bloquear decisões legislativas, por ofensa à propriedade ou à liberdade, gerou uma forte reação" (VILHENA, 2006, p. 478).

${ }^{32}$ Em Buenos Aires, entre 1925 e 1928, Alejandro Unsay publicava os três volumes de seu Legislación del Trabajo, um estudo comparado de lei e políticas públicas de regulação social (intervenção do Estado no domínio econômico, organização administrativa e constitucional, assistência médica e previdenciária) (BENDER, 2006, p. 254 - tradução livre). 
que pesquisaram fontes legislativas e doutrinárias sobre a regulação do trabalho feminino de diversos países, dentre os quais, Reino Unido, Alemanha, França, Suíça, Áustria, Holanda e Itália ${ }^{33}$.

No entanto, de 1919 em diante, houve um grande arrefecimento dos movimentos sindicais, garantido pelos governos Warren Harding (1920-1924), Calvin Coolidge (19241928) e Herbert Hoover (1928-1932). Após os primeiros anos da década de 1920, o suporte à legislação anti labor injunction começou a crescer. A ameaça vermelha (Red Scare) havia sido dissipada e o número de greves havia sido reduzido, o que contribuiu para a diminuição da preocupação da opinião pública com uma possível "revolução comunista”. Em 1924, a AFL endossou a campanha do progressista La Follette que tinha como plataforma política a defesa dos sindicatos e o ataque aos Tribunais e Cortes federais por seu comportamento antitrabalhista (PURCELL, 2000, p. 85).

Em 24 de outubro de 1929, ocorreu a "Quinta-feira negra". A Bolsa de Valores norte-americana caiu em um terço e iniciava-se a pior crise econômica na história do capitalismo mundial. Até 1932, 5 mil bancos norte-americanos haviam falido, a produção industrial caíra 46\%, o PIB (Produto Interno Bruto) diminuíra um terço e os preços, a metade. Em consequiência disso, mais de 15 milhões de norte-americanos (25\% do total da população economicamente ativa) ficaram desempregados (PURDY, 2007, p. 205).

Alan Brinkley, atualmente dean da Faculdade de História da Columbia University $^{34}$, defende que as principais causas para a Grande Depressão foram (i) a homogeneidade da economia (dependente de poucas matrizes industriais, tais como a automobilística e a construção civil) norte-americana durante os anos 1920; (ii) a desigualdade de distribuição de renda e seus efeitos sobre o mercado consumidor; e (iii) a

\footnotetext{
33 Outro exemplo dessa internacionalização da questão social, agora na esfera acadêmica norte-americana, ocorreu em 1910, quando John R. Commons iniciou o projeto da Industrial Commission Law para Wisconsin. Para tanto, Commons, na época professor da Wisconsin University, contratou 50 estudantes de pósgraduação com domínio dos mais diversos idiomas do mundo, com o objetivo de estudar toda legislação trabalhista do globo (BENDER, 2006, p. 254 e p. 281 - tradução livre).

${ }^{34}$ Os nomes das univerisdades norte-americanas não foram traduzidos para a língua portuguesa pois são nomes próprios. Nesse sentido, sigo Umberto Eco: “ouvimos falar o tempo todo de Universidade 'de Harvard' e Universidade 'de Yale' como se Harvard e Yale fossem duas localidades ao passo que são dois nomes próprios, nem nos passa pela cabeça que a Università Cattolica possa estar instalada na cidadezinha praiana de Cattolica. Portanto, é por correção e não por mania de anglicismos que devemos dizer George Bush e não Giorgio Bush (...)” (ECO, 2007, p. 82).
} 
fragilidade do sistema financeiro (BRINKLEY, 2004). O presidente Hoover e o Congresso, controlado pelos republicanos, não foram capazes de reverter a crise. Diante disso, o candidato do Partido Democrata à presidência, Franklin Delano Roosevelt, ganhou as eleições de 1932 com a promessa de que restauraria a confiança na economia e na sociedade.

Entre o início da crise em 1929 e 1933, os movimentos organizados de trabalhadores tinham perdido muito sua força (apenas cerca de 5\% da força de trabalho norte-americana). No entanto, com a edição da 7. ${ }^{a}$ Seção do National Industrial Recovery Act (NIRA), os trabalhadores voltaram a se organizar. Entre 1933 e 1934, o número de greves aumentou drasticamente ${ }^{35}$ ("from grocery clercks to lumberjacks, from East to West”). Além disso, também mudaram as pautas de reivindicações. Se antes de 1934 concentravam-se nas questões envolvendo salário e redução de horas de trabalho, após esse ano os trabalhadores passaram a pleitear o reconhecimento do direito à organização sindical (SCHLESINGER, 2003, p. 386).

Entre 1933 e 1934, Roosevelt lançou o primeiro New Deal, com o Blue Eagle Program e as Triple A Laws. Tratava-se de um pacote de reformas para promover a recuperação industrial e agrícola, regular o sistema financeiro e providenciar mais assistência social e obras públicas. Em 1933, foi criada a National Recovery Administration (NRA). No mesmo ano, foi editado o National Industrial Recovery Act (NIRA), legislação que definiu uma série de acordos entre empresários, governo e trabalhadores, estabelecendo limites para os preços, salários e competição. Os programas de planejamento regional, as obras públicas e os subsídios à construção civil buscavam recuperar a economia, enquanto os empregos públicos e o sistema previdenciário buscavam minimizar os efeitos do desemprego (PURDY, 2007, pp. 209-210). De acordo com alguns historiadores norte-americanos como Howard Zinn, o NRA foi controlado pelas grandes empresas e, desde o início, teria servido aos seus interesses (ZINN, 2005, p. 392). Outros historiadores, como Peter Irons, acreditam que o NIRA era extremamente semelhante ao Estado Corporativo fascista de Benito Mussolini. O autor utiliza como um

\footnotetext{
${ }^{35}$ Em 1934, houve 700 greves e lockouts nos Estados Unidos (Estatísticas do Ministério do Trabalho norteamericano, 1935, 40 Monthly Labor Review 1266).
} 
indicativo disso a admiração que o General Hugh Johnson, responsável pela NRA, tinha pelo Duce italiano (IRONS, 1999, p. 300).

Por outro lado, muitos pensadores/filósofos significativos para o pensamento norteamericano, como o pragmatista John Dewey, defendiam o controle social e a tomada de medidas de emergência como garantia da democracia americana. Em 1939, no texto Freedom and Culture, ao analisar o liberalismo no interior da cultura norte-americana, Dewey entendia que:

\footnotetext{
"Quando as condições que concorrem para o desemprego são tão extensamente ramificadas como o são presentemente, a ação política assume uma importância para os trabalhadores, empregados e desempregados, que ela não tem quando as condições são estáveis e a oportunidade para emprego é satisfatória e geral. Em todas as nações industrializadas há movimentos para dar trabalho por meio de projetos do governo: há planos para compensar, por meio de assistência financeira, os males resultantes de falharem os industriais e os capitães de finanças em prever os meios de ganhar a vida (...) as condições econômicas estão de tal modo fora de controle e de governo, que se tem de recorrer às medidas de emergência" (DEWEY, 1970, p.152).
}

Dewey identificava que a democracia norte-americana via-se ameaçada tanto pela esquerda, como pela direita. Percebia que movimentos (por ele qualificados de populistas) como os square deals e new deals acompanhavam a depressão econômica e, em especial, a parcela da população mais afetada, como agricultores e trabalhadores das fábricas (operários) (DEWEY, 1970, pp. 149-152).

Em 1934, a Suprema Corte tomou uma decisão diferente de sua postura tradicional em relação à regulação do Estado sobre os negócios entre os particulares. Tratava-se do caso Home Building \& Loan Association v. Blaisdell. O caso levava à Suprema Corte a decisão sobre a constitucionalidade de uma lei estadual de Minnesota que permitia a declaração de moratória pelos devedores hipotecários de financiamentos de casa própria. A 
Suprema Corte decidiu-se pela constitucionalidade da lei, entendendo que era dever do Estado garantir as condições de existência de uma comunidade em situações de emergência, tais como a situação social dos devedores hipotecários de Minnesota (LOPES, 2002a, p. 371).

No entanto, na primavera de 1935, a Suprema Corte considerou uma série de medidas do segundo New Deal inconstitucionais, tais como a Lei de Recuperação da Indústria Nacional (National Industrial Recovery Act - NRA), aprovada pelo Congresso em junho de 1933 e que, dentre outras matérias, regulamentava as horas de trabalho e os salários nas indústrias (SCHWARTZ, 1966, p. 208). O parágrafo inicial da lei descrevia "uma emergência nacional geradora de desemprego e desorganização gerais da indústria que sobrecarregava o comércio interestadual e exterior, afetava o bem-estar público e enfraquecia gradualmente os padrões de vida do povo americano” (NRA, 1933).

Essa legislação de emergência foi levada à Suprema Corte a partir do caso Schechter Poulttry Corp. v. United States ${ }^{36}$. A decisão da Corte sobre o caso Schechter foi acompanhada com grande apreensão pela sociedade norte-americana. Estava em jogo a constitucionalidade da legislação de emergência do New Deal. Sabia-se que a Corte estava realmente dividida entre progressistas (pró-New Deal) e conservadores (anti-New Deal). Três ministros eram declaradamente progressistas: Louis Brandeis, Benjamin Nathan Cardozo e Harlan Fiske Stone (conhecidos como os três mosqueteiros). Quatro ministros tinham tendência a adotar posições conservadoras: James McReynolds, George Sutherland, Willis Van Devanter e Pierce Butler (conhecidos como os quatro Horseman). O Chief Justice (Ministro Presidente) Charles Evans Hughes e o Justice (Ministro) Owen Roberts, o mais jovem ministro, seriam o "fiel da balança". Se o Tribunal seguisse a mesma orientação que havia sido predominante na década anterior, a seção 7 do NIRA seria declarada inconstitucional (LEUCHTENBURG, 1963, p. 143). Foi exatamente isso o que ocorreu.

\footnotetext{
36 No caso Schechter Poulttry Corp. v. United States, a companhia Schechter Poulttry, empresa que comercializava aves no atacado em New York, foi acusada de violar o Código de Aves Domésticas Vivas por (i) desrespeitar os limites de horas de trabalho, (ii) não pagar o salário mínimo e (iii) dispensar tratamento preferencial a clientes diferenciados, 295 U.S. 495 (1935).
} 
O argumento utilizado pela Suprema Corte para declarar a seção 7 do NIRA inconstitucional era o de que atribuía muitos poderes ao presidente dos Estados Unidos. No entanto, para alguns historiadores, dentre os quais Howard Zinn e Bernard Bellush, o NIRA havia estabelecido uma divisão desordenada de poderes entre o Governo e os grandes líderes industriais (ZINN, 2005, p. 393). A posição da Suprema Corte, porém, não foi suficiente para impedir que o Governo continuasse a estabelecer formas de regulação da economia e das relações de trabalho. Em substituição ao National Industrial Recovery Act, seria criado o National Industrial Relations Act, conhecido como Wagner Act, uma versão expandida da seção 7 do NIRA.

O ano de 1937 marcou uma importante virada na relação entre Roosevelt e a Suprema Corte. No início de 1937, logo após sua reeleição, Franklin Roosevelt ameaçou apresentar ao Congresso um projeto que ficou conhecido como Court-packing plan ${ }^{37}$. A proposta era permitir que o presidente nomeasse um novo ministro para cada ministro com mais de 70 anos da Suprema Corte. Como a Corte, em 1937, era formada predominantemente por ministros com mais de 70 anos, o projeto teria permitido a Roosevelt indicar seis novos membros imediatamente e, assim, transformar completamente sua equação ideológica ${ }^{38}$.

Após a ameaça de aumento do número de ministros da Suprema Corte com o objetivo de esvaziar o poder dos ministros “conservadores" (Court-packing plan), ocorreu

\footnotetext{
${ }^{37}$ Mesmo antes de sua reeleição, mais especificamente após a derrota no caso Schechter, em maio de 1935, Roosevelt teria ordenado ao Ministro da Justiça (Attorney General) Homer Cummings que preparasse, junto a uma equipe de jovens advogados, uma pesquisa com argumentos e dados que pudessem minar o poder da Suprema Corte.

38 "Durante o final das décadas de 1930 e 1940, uma nova "Corte de Roosevelt" tomou forma. Além de Hugo Black e Stanley Reed, o presidente nomeou Felix Frankfurt e William O. Douglas em 1939 e Frank Murphy em 1940. No ano seguinte, ele colocou Robert H. Jackson e James F. Byrnes no Tribunal. Em 1943, Wiley B. Rutledge sucedeu Byrnes, que renunciou para atuar como diretor do Gabinete de Estabilização Econômica. Portanto, quatro anos após a batalha do tribunal, apenas Stone e Roberts continuaram. Levou quase uma década, mas Roosevelt finalmente refez o Tribunal" (PURCELL, 2000, p. 201 - tradução livre). "During the late 1930s and 1940s a new "Roosevelt Court" took shape. In addition to Hugo Black and Stanley Reed, the presidente appointed Felix Frankfurte and William O. Douglas in 1939 and Frank Murphy in 1940. The following year he placed Robert H. Jackson and James F. Byrnes on the Court. In 1943, Wiley B. Rutledge succeeded Byrnes, who had resigned to serve as director of the Office of Economic Stabilization. Thus, four years after the Court fight, only Stone and Roberts remained. It had taken almost a decade, but Roosevelt had finally remade the Court" (PURCELL, 2000, p. 201 - original).
} 
uma significativa transformação na formação de posições do Tribunal ${ }^{39}$. Em 29 de março de 1937, a Suprema Corte julgou o caso West Coast Hotel v. Parrish, por cinco votos contra quatro, formando na nova maioria o juiz Owen J. Roberts, que até então pertencera ao grupo conservador, - constituído dos juízes van Devanter, Sutherland, MacReynolds e Butler - contrariou os precedentes Adkins v. Children's Hospital (1923) e Morehead v. New York ex rel. Tipaldo (decidido apenas seis meses antes - 1936) e declarou a constitucionalidade da lei do salário mínimo (Wage Act) do Distrito de Colúmbia (Washington) (RODRIGUES, 1992, p. 121). Em acórdão redigido por Charles Evans Hughes, a Corte considerava constitucional a existência de leis estaduais que definissem um salário mínimo. $\mathrm{O}$ voto de Hughes rompeu, inclusive, com o conceito de constitucionalidade da liberdade de contratar. Para o Chief Justice, a Constituição nada falava sobre "liberdade de contratar" ${ }^{40}$, mas de liberdade e proibição de restrição de liberdade sem um devido processo legal (IRONS, 1999, p. 316).

${ }^{39}$ Por que a Suprema Corte mudou em West Coast Hotel v. Parrish? Há um importante debate, ainda em curso, entre os historiadores e juristas norte-americanos sobre as causas para essa drástica mudança de posição da Suprema Corte, que ficou conhecida mesmo como o conflito entre a Velha Corte e o New Deal (BRINKLEY, 2005, p. 2). O debate divide-se entre internalistas, defensores da tese de que as causas para essa mudança na interpretação constitucional durante o período do New Deal estão relacionadas a transformações doutrinárias/intelectuais, e externalistas, que defendem que as razões para essa mudança foram políticas. Dentre os internalistas estão os professores de direito Barry Cushman, Richard Friedman e Bruce Ackerman. Já dentre os externalistas estão os historiadores William E. Leuchtenburg e Laura Kalman (KALMAN, 1998-1999, p. 2167; ACKERMAN, 1998, p. 343). Bruce Ackerman critica a forma como os juristas analisam o papel da Suprema Corte durante o New Deal: "na medida em que a narrativa profissional insiste na afirmação de que a Reconstrução foi um processo substancialmente criativo, ela supõe, ao mesmo tempo, que a Reconstrução não tenha sido nada original quanto ao procedimento (...) em contraste com as duas primeiras fases de transformação, os juristas atuais não descrevem nem os aspectos substantivos e nem procedimentais do New Deal, propagando uma tese de criação constitucional. O triunfo do governo nacional ativista é mediado pelo mito da redescoberta - como se os Federalistas Fundadores tivessem previsto o trabalho de Franklin Delano Roosevelt e se surpreendido ao saber que as grandes batalhas da década de 1930 eram necessárias para conquistar a legitimação constitucional do estado do bem-estar-social" (ACKERMAN, 2006, pp. 59-60). No entanto, de acordo com as interpretações mais recentes de pesquisadores do período, a ameaça aos ministros da Suprema Corte foi fundamental para sua tranasformação. Ao menos, o mais novo ministro da Corte, Owen Roberts, pareceu, na visão desses historiadores do direito, mudar de posição em resposta ao crescimento da pressão política para começar a apoiar a legislação do New Deal. A maioria das decisões da Suprema Corte anti-New Deal antes de 1937 haviam tido o resultado de cinco ministros contrários e quatro favoráveis à legislação social. Desse modo, a mudança de Owen Roberts foi decisiva para a redefinição de forças da Corte. Assim, para se entender as mudanças da Corte, é essencial compreender as razões que levaram Owen Roberts a mudar de posição (BRINKLEY, 2005, p. 1).

${ }^{40}$ Em um dos trechos de seu voto, Hughes disse que: "A liberdade, em cada uma de suas fases, tem sua história e conotação. Mas a liberdade protegida é liberdade em uma organização social que exija proteção da lei contra os males que ameaçam a saúde, segurança, moral e bem estar das pessoas. A liberdade sob a Constituição está portanto necessariamente sujeita às restrições do devido processo e a uma regulamentação que seja razoável em relação ao seu indivíduo e é adotada nos interesses da comunidade no devido processo (...) o caso de Adkins x Children's Hospital deve ser e é rejeitado" [300 U.S. 379, 386-400 (1937) - tradução livre]. "Liberty in each of its phases has its history and connotation. But the liberty safeguarded is liberty in a 
No caso West Coast Hotel v. Parrish, de 1937, o que estava em jogo era o salário mínimo para as mulheres, concretizado no processo de Elsie Parrish contra a West Coast Hotel Company por salários atrasados ${ }^{41}$. Elsie Parrish havia trabalhado no hotel Cascadian, de propriedade da West Coast Hotel Company, recebendo 22 cents por hora de trabalho de limpeza de banheiros e arrumação de camas, o que significava menos do que o salário mínimo semanal de USUS\$14,30 determinado pela lei estadual do Distrito de Columbia. Depois de o tribunal estadual de Washington ter negado o direito de Elsie Parrish com base na decisão da Suprema Corte no caso Adkins, de 1923, o caso foi aceito pela Suprema Corte (IRONS, 1999, p. 316).

Tratava-se, na verdade, da vitória do argumento do voto divergente de Oliver Holmes no caso Lochner (1905), mais de 20 anos após seu julgamento. A partir do caso West Coast Hotel (1937), a Suprema Corte adotou a posição de que as leis podem regular matéria econômica, "se for entendido que o corpo representativo que promulgou tais leis tenha agido de acordo com bases racionais. Esse modelo de 'base racional' é altamente deferente às ações legislativas" (TRIBE, 2007, pp. 83-84). Finalmente, a questão social tornar-se-ia a nova tendência e em 1938, no caso United States v. Darby ${ }^{42}$, a Suprema Corte considerou constitucional a Lei dos Padrões Justos de Trabalho (Fair Labor Standards Act), que não apenas proibiu o transporte interestadual de mercadorias produzidas em condições de trabalho irregulares, como interditou a produção daqueles bens para o comércio (CORWIN, 1986, p. 59).

Assim, consolidava-se uma mudança na forma como a Suprema Corte, a base do pensamento jurídico norte-americano, compreendia a questão social. Entre Lochner (1905) e Parrish (1937) operava-se uma transformação completa em uma instituição que era a

social organization which requires the protection of law against the evils wich menace the health, safety, morals and welfare of the people. Liberty under the Constitution is thus necessarily subject to the restraints of due process, and regulation wich is reasonable in relation to its subject and is adopted in the interests of the community is due process (...) the case of Adkins v. Children's Hospital should be, and it is, overruled" [300 U.S. 379, 386-400 (1937) - original].

41 Tratava-se das lutas de muitos trabalhadores para "manter seus corpos e almas unidos" durante a Depressão, como escrevera o Justice Stone em seu voto dissidente no caso Morehead (IRONS, 1999, pp. 316-317).

42312 U.S. 100 (1941). 
própria Constituição norte-americana ${ }^{43}$. No centro do capitalismo mundial, institucionalizavam-se novos termos para as relações entre capital e trabalho. O próximo passo será analisar como esse processo desenrolou-se na periferia do capitalismo mundial. Antes disso, no entanto, há um passo intermediário: o exame das diferenças existentes entre Estados Unidos e Brasil quanto aos espaços irradiadores do discurso jurídico.

43 “O que nos impede de reconhecer que os juristas da República intermediária poderiam ter mudado suas diretrizes a partir da síntese específica para a síntese compreensiva, reunindo os elementos díspares da Fundação e da Reconstrução em um padrão doutrinário que corresponda ao contexto de sua época? Por um lado, o governo nacional emergiu como o fiador do direito de todos os cidadãos sobre a posse de seu próprio trabalho e de sua propriedade, da liberdade de negociar livremente para o seu próprio benefício, sendo protegidos contra a escravização da política dos Estados. Por outro, o governo nacional se caracterizou como instância política com poderes limitados, sem autoridade plenária para impedir que os Estados-membros fossem os legisladores primários da vida econômica. Embora nossas respostas sejam diferentes, por que negar que elas já tenham sido interpretações da Constituição? Há uma maneira melhor de entender o New Deal, uma maneira que desvende um significado mais profundo na luta entre a presidência de Roosevelt e a Suprema Corte durante a Grande Repressão. Dentro do retrato mítico da redescoberta, o desafio da Velha Corte com relação ao New Deal, no período entre 1932 e 1937, simplesmente revelou o caráter arbitrário da prática interpretativa que os juristas experimentaram nos sessenta anos antecedentes. Aparentemente, teria sido melhor para a Constituição e para o país se a Corte tivesse deixado claro que a partir de 1933 (...), Franklin Roosevelt e o Congresso democrático não se engajariam em uma política usual, exigindo a nova sistemática do New Deal para os norte-americanos, mas estariam, em vez disso, falando em nome de articulações do povo estadunidense para a criação de uma norma constitucional autêntica. Minha (re)interpretação do direito da República intermediária desafia essa visão. A defesa da Velha Corte da sua síntese compreensiva veio a contribuir e não feriu o processo democrático pelo qual o povo determinou novos ordenamentos ao governo nos anos 30. Na dramatização dos princípios constitucionais fundamentais erguidos pelo New Deal, a velha Corte contribuiu para uma transformação mais democrática e centralizada da identidade constitucional. Como se mostrasse um espelho ao povo estadunidense que representava os princípios fundamentais da República intermediária, a velha Corte facilitou para os cidadãos norteamericanos dos anos 30 o esclarecimento do que eles consideravam inadequado na estrutura tradicional - e, finalmente, legitimaram constitucionalmente a nova visão do governo ativista nacional que não possuía raízes populares profundas na nossa experiência constitucional anterior" (ACKERMAN, 2006, pp. 143-144). 


\section{A COMPARAÇÃO ENTRE DIFERENTES LOCUS DE PODER}

O Supremo Tribunal Federal e a Suprema Corte norte-americana ou o debate legislativo e doutrinário e a Suprema Corte norte-americana

Antes de iniciar a contextualização histórica do debate brasileiro sobre legislação social, entendi ser necessário explicar como esse processo ocorreu em um locus bastante distinto daquele em que se deu o debate norte-americano. Enquanto o debate norteamericano foi travado essencialmente em torno da Suprema Corte, o debate brasileiro ocorreu na doutrina jurídica, nos órgãos da burocracia estatal e nas comissões que elaboraram os projetos legislativos.

Embora o modelo constitucional brasileiro e, particularmente, o sistema de controle judicial das leis adotado com a Constituição de 1891, tenha sido declaradamente pensado a partir do modelo norte-americano ${ }^{44}$, essa importação foi incompleta, uma vez que não houve o transplante da regra do precedente, nem do writ of certiorari (avocatória) (LOPES, 2006, p. 23). Em função desse transplante incompleto e da inexistência de soluções próprias para as lacunas deixadas por essa importação inacabada, realçam-se, ainda hoje, diferenças fundamentais entre o papel institucional desempenhado pela Suprema Corte norte-americana e aquele exercido pelo Supremo Tribunal brasileiro. Enquanto a Suprema Corte norte-americana é a própria Constituição norte-americana, o Supremo Tribunal brasileiro acaba exercendo mais o papel de corte recursal do que de corte constitucional.

Não obstante essa disfunção da organização judiciária brasileira, há uma diferença fundamental entre a forma como a Suprema Corte e o Supremo Tribunal relacionam-se com a doutrina e como a doutrina relaciona-se com esses tribunais. Enquanto a doutrina norte-americana é produzida basicamente em torno das questões discutidas pela Suprema Corte $^{45}$, o Supremo Tribunal é que define suas teses a partir da doutrina brasileira. Essa

\footnotetext{
44 "Embora as Constituições sejam diferentes, os sistemas de governo são impressionantemente similares: esses são os dois países mais populosos do hemisfério ocidental, ambos são Repúblicas Federativas com duas Casas Legislativas, ambos possuem um Poder Executivo nacional separado e eleito, e ainda, ambos possuem um Poder Judiciário com poder para invalidar leis que conflitem com a Constituição. Portanto, é de se supor que freqüentemente apareçam problemas semelhantes nos dois países” (TRIBE, 2007, p. x1i).

45 "Um livro de direito constitucional estadunidense é uma coletânea de decisões da Suprema Corte em torno dos grandes temas: Estado federal, sistemas eleitorais, direitos individuais e assim por diante. Não se estuda direito constitucional fazendo-se exegese do texto legal (constitucional), mas discutindo-se como aquele
} 
dependência do Supremo Tribunal brasileiro em relação à doutrina jurídica ${ }^{46}$ é demonstrada a partir do imenso número de citações doutrinárias que, historicamente, têm sido feitas nos votos proferidos pelos ministros daquele tribunal. Ao contrário dos ministros da Suprema Corte norte-americana que fundamentam seus votos a partir dos próprios precedentes da Corte, a maioria dos ministros da história do Supremo brasileiro tem condicionado suas decisões aos conceitos e argumentos produzidos pela doutrina.

Além dessa drástica diferença de papéis institucionais e culturais existente ainda hoje entre o Supremo brasileiro e a Suprema Corte norte-americana, havia ainda as dificuldades proporcionadas pela forma distinta como os governos desses dois países dialogaram com seus principais tribunais. Enquanto o Governo Vargas foi um período de Estado de exceção, o Governo Roosevelt, por mais que se tenha dito o contrário na historiografia norte-americana, ainda manteve as bases de um Estado Democrático de Direito.

O desenho institucional norte-americano havia alcançado uma solidez tal que Franklin Delano Roosevelt foi obrigado a dialogar com a Suprema Corte. A Suprema Corte norte-americana, com exceção do período da Guerra Civil (Guerra de Secessão), atuava ininterruptamente desde a Revolução Americana (Independência). Desse modo, mesmo que tenha chegado ao ponto de ameaçá-la de neutralização com o aumento do número de ministros (packing the court), FDR foi submetido aos ditames de uma Corte legitimada historicamente como a própria Constituição norte-americana ${ }^{47}$.

Por outro lado, o Supremo Tribunal Federal brasileiro, criado no meio da Proclamação da República, ainda não tinha conquistado um papel na cultura jurídica

texto foi aplicado ao longo do tempo. Naturalmente, a idéia vale para todos os ramos do direito e não são poucos os ramos legislados, mesmo no direito privado" (LOPES, 2006, pp. 23’24).

${ }^{46}$ Uma demonstração da medida da dependência do Supremo brasileiro em relação à doutrina jurídica está no fato de que, vários juristas brasileiros, como Oliveira Vianna e Francisco Campos, pelo governo, e João Mangabeira, pela oposição, citaram e debateram sobre uma série de decisões da Suprema Corte norteamericana, muitas vezes comparando-as entre si e dominando as variações da jurisprudência, mas quase não se referiram às decisões do Supremo Tribunal Federal. As próprias decisões do Supremo Tribunal Federal eram muito mais repletas de referências às decisões norte-americanas do que às decisões brasileiras.

${ }^{47}$ Nesse sentido, Edward Samuel Corwin afirmou que: "pelas suas decisões interpretativas da Constituição altera a Corte Suprema, constantemente, o efeito prático e a aplicação desta. Como disse acertadamente Woodrow Wilson, a Corte Suprema é "uma espécie de Convenção Constitucional em sessão contínua"” (CORWIN, 1986, p. 14). 
brasileira e muito menos na sociedade brasileira que o permitisse fazer frente a qualquer ação de governo. No Brasil, a interpretação constitucional somente foi atribuída ao judiciário com a República ${ }^{48}$. Não havia, ainda, uma tradição de controle de constitucionalidade das leis pelo Judiciário.

Além disso, durante a Era Vargas, o desenho institucional brasileiro do controle de constitucionalidade exercia-se somente a partir do controle difuso sem precedente judicial. Foi apenas em 1965, durante a ditadura militar, que se instituiu o controle concentrado de constitucionalidade das leis (Emenda Constitucional n. 16) (LOPES, 2006, p. 25).

Outro problema era a breviedade do tempo de vigência de diferentes modelos constitucionais, o que trazia a pergunta sobre quais seriam os valores constitucionais a serem resguardados se, entre 1891 e 1945, o país teve três constituições distintas ${ }^{49}$ (1891, 1934 e 1937) e vivenciou uma série de regimes de exceção ${ }^{50}$ com declarações de estado de sítio, estado de guerra e processos revolucionários.

\footnotetext{
${ }^{48}$ A supressão de um órgão contencioso administrativo com as dimensões do Conselho de Estado imperial e a absorção de suas funções pelo Poder Judiciário republicano geraram um significativo déficit operacional quanto à resolução de conflitos pelo Estado. $\mathrm{O}$ aparato institucional do judiciário do Império estava preparado para adjudicar conflitos entre interesses individuais e não para lidar com problemas de ordem pública ou coletiva. Esses problemas eram encaminhados ao contencioso administrativo, que tinha como órgão de cúpula o Conselho de Estado. Embora as transformações no desenho institucional e funcional do Poder Judiciário, promovidas pela Constituinte republicana, tenham transferido as funções do contencioso administrativo imperial para o Poder Judiciário, a cultura jurídica ainda guardou resquícios de um modo de pensar a adjudicação como resposta a conflitos entre indivíduos, mesmo quando se tratavam de questões envolvendo o Estado.
}

${ }^{49}$ A análise da jurisprudência constitucional no Brasil enfrenta problemas como: (i) a grande quantidade de ações já julgadas e pendentes de julgamento pelo STF; (ii) a inexistência no sistema brasileiro de controle de constitucionalidade do mecanismo do stare decisis; (iii) a não sedimentação jurisprudencial relativa à separação dos poderes e ao controle do poder normativo da burocracia gerada pela alternância entre regimes democráticos e autoritários e as sete constituições republicanas; (iv) as estratégias informais de decisão do Supremo Tribunal Federal nos casos em que uma decisão final de mérito poderia provocar amplas conseqüências políticas ou econômicas negativas (ROCHA, 2004, pp. 116-124).

${ }^{50}$ Com a frase, "Soberano é quem decide sobre o estado de exceção" (SCHMITT, 1988, p.13), que inicia seu livro Teologia Política (1922), Carl Schmitt (1888-1985) definiu soberania como decisão sobre o estado de exceção, o que significa dizer que o ordenamento está à disposição de quem decide. O soberano, assim, está, ao mesmo tempo, dentro e fora do ordenamento jurídico, pois ao utilizar o seu poder de suspender a validade do direito, coloca-se legalmente fora da lei. Traduz-se, desse modo, o que para Agamben será a estrutura topológica do estado de exceção, qual seja, estar-fora e, ao mesmo tempo, pertencer. Em síntese, é a exceção que revela o fundamento da ordem jurídica, que, por sua vez, está subordinada às condições efetivas de sua instauração (AGAMBEN, 1998, pp. 19-21 e 31-34; BERCOVICI, 2004, pp. 65-66). 
Não havia, assim, nem maturidade institucional nem estabilidade constitucional para que o exercício do controle de constitucionalidade das leis fizesse do Supremo brasileiro o principal locus do debate jurídico brasileiro. Compreender como Vargas garantiu essa neutralização do Supremo Tribunal será, portanto, o próximo passo desta dissertação.

\section{Um Supremo Tribunal Federal ${ }^{51}$ (ou Corte Suprema) neutralizado}

Durante o governo Vargas, adotou-se uma série de medidas que enfraqueceram o papel institucional do Supremo Tribunal Federal ${ }^{52}$. No Governo Provisório, foi criado o Tribunal Especial para processar e julgar crimes políticos e o número de ministros do Supremo Tribunal Federal foi diminuído pelo Decreto n. $19.711^{53}$, de fevereiro de 1931, de 15 para 11. Quando houve a Revolução (ou golpe) de 1930, os ministros que compunham o Supremo eram: (i) Rodrigo Octávio Landgaard de Menezes (1929), (ii) Firmino Antonio da Silva Whitaker Filho (1927), (iii) Francisco Cardoso Ribeiro (1927), (iv) José Soriano de Souza Filho (1927), (v) Antonio Bento de Faria ${ }^{54}$ (1925-1945), (vi) Arthur Ribeiro de

51 Entre 1934 e 1937, período de vigência da Constituição de 1934, o Supremo Tribunal Federal era denominado Corte Suprema.

52 A fragilidade do Supremo Tribunal ficava evidente diante das anulações de suas decisões pelo governo. Um caso bastante conhecido foi o que envolveu a cláusula-ouro dos contratos e a Conferência de Bretton Woods. Sob pressão da embaixada norte-americana, Vargas anulou por decreto um acórdão do Supremo que mantinha a abolição da cláusula-ouro dos contratos, de acordo com a Lei Aranha de 1931, no julgamento do recurso interposto pela Companhia de Tecidos América Fabril (COSTA, 2006, p. 99).

53 Além de reduzir o número de ministros, o Decreto ${ }^{\circ} 19.711$ dividiu o Supremo em duas turmas de cinco ministros, proibiu aos magistrados o exercício de qualquer cargo por eleição, nomeação ou comissão, mesmo que gratuito, ou qualquer outra função pública, com exceção para o magistério.

${ }^{54}$ Antônio Bento de Faria, nomeado ministro do Supremo pelo presidente Arthur Bernardes em 1925, foi um dos poucos ministros da República Velha que permaneceram no Supremo Tribunal Federal até o final do Estado Novo (1937-1945), tendo sido seu presidente entre os anos de 1937 e 1940 (COSTA, 2006, p. 74). "Filho de José Bento de Faria e Francisca Leite de Faria, nasceu aos 4 de fevereiro de 1876 na cidade do Rio de Janeiro. Fez o curso ginasial no Colégio D. Pedro II e formou-se em 1895 pel Faculdade de Direito do Rio de Janeiro. Durante a revolta de 1893, ainda estudante, lutou ao lado do Marechal Floriano Peixoto recebendo, em dezembro de 1894, as honras do posto de alferes do Exército. Foi funcionário dos Correios e promotor em Barra do Piraí" (RODRIGUES, 2002, p. 275). Foi advogado em Bom Jardim, escreveu durante alguns anos para o jornal O País e, já como ministro do Supremo, foi diretor da Revista de Direito Civil, Comercial e Criminal. Publicou Código Comercial Brasileiro (1903, 4ª . Ed. 1929), Anotações teóricopráticas ao Código Penal do Brasil (1904, 4a. Ed. 1929), Das marcas de fábrica (1906), Das falências (1908), Sobre o direito de expulsão (1929), Sobre o direito de extradição (1930), Pareceres (1933-1934), Decisões da Corte Suprema (1935-1936). 
Oliveira (1923), (vii) Geminiano da Franca (1922), (viii) Pedro Joaquim dos Santos (1919), (ix) Hermenegildo Rodrigues de Barros (1919), (x) Edmundo Pereira Lins (1917), (xi) Antonio Joaquim Pires de Carvalho e Albuquerque (1917), (xii) Pedro Affonso Mibieli (1912), (xiii) Eduardo Muniz Barreto (1910), (xiv) Carolino de Leoni Ramos (1910) e (xv) Godofredo Xavier da Cunha (1909). Com o Decreto n. 19.711/1931, Geminiano da Franca, Pedro Joaquim dos Santos, Antonio Joaquim Pires de Carvalho e Albuquerque ${ }^{55}$, Pedro Affonso Mibieli, Eduardo Muniz Barreto e Godofredo Xavier da Cunha foram aposentados. Carolino de Leoni Ramos faleceu. Para as três vagas remanescentes foram indicados Eduardo Espínola ${ }^{56}$ (1931-1945), Plínio de Castro Casado (1931-1938) e João Martins de Carvalho Mourão. Francisco Cardoso Ribeiro faleceu em 1932. Para sua vaga foi nomeado Laudo Ferreira de Camargo (1932-1951).

Desse modo, entre 1930 e 1945, o Supremo Tribunal Federal teve sua composição totalmente renovada. Os ministros nomeados durante a República Velha ou (i) foram removidos pelo Decreto de 1931, ou (ii) se aposentaram, ou (iii) faleceram antes do Estado Novo. O ministro Edmundo Pereira Lins, empossado em 1917, aposentou-se em 1937.

55 San Tiago Dantas escreveu sobre a biografia de Pires e Albuquerque, membro do Ministério Público bahiano desde 1886, procurador-geral entre 1919 e 1930 e ministro do STF até 1931, e a expulsão dos seis ministros em 1931: "Toda a sua carreira de magistrado, desde o ingresso no ministério público baiano em 1886, até o dia em que Venceslau Brás lhe deu o posto devido ao seu alto merecimento no Supremo Tribunal, e mesmo os seus 11 anos incansáveis de procurador-geral, defendendo, com a energia às vezes leonina da sua palavra, os interesses superiores da lei e do Estado, não lhe teriam valido senão o aplauso e a consideração que devemos a tantos outros, se sobre a sua carreira, nimbada de êxitos sucessivos, não se tivesse abatido, em 1931, o golpe da expulsão do Supremo Tribunal. Embora esses fatos sejam de ontem, poucos aqui se lembrarão perfeitamente do que foi o ato do Governo Provisório expulsando do Supremo seis ministros, entre eles Pires e Albuquerque, que exercia desde 1919 as funções de procurador-geral (...). Sua demissão do Supremo, pelo crime de ter sido um procurador-geral sem reservas, sem reticências, sem habilidade, que crepitou dia e noite na chama de sua própria cólera cívica (...). Não faltaram vozes, em 1931, que justificassem o governo revolucionário pela depuração do Supremo, especialmente em relação a Pires e Albuquerque, a quem se acusava de haver exercido com paixão, sem serenidade, sem imparcialidade, as funções de procurador-geral. Não se compreendia que o juiz, sentado na cúria da procuradoria pública, devia converter-se, e de fato se convertera, em advogado" (DANTAS, 1962, pp. 133-135).

56 "Filho de Antônio José Espínola e Francisca C. Godinho Espínola, nasceu em 6 de novembro de 1875, em Salvador, Bahia. Bacharelou-se em ciências sociais na Faculdade de Direito de Recife em março de 1895 e em ciências jurídicas em 5 de dezembro do mesmo ano pela Faculdade de Direito da Bahia. Promotor público (1896-1903). Aprovado em concurso para a Faculdade de Direito da Bahia, foi nomeado lente desta faculdade em outubro de 1902. Em 1928, compareceu como delegado do Brasil à $6^{a}$ Conferência Panamericana, reunida em Havana. Em 1929, foi nomeado agente do Brasil junto à Corte Permanente de Justiça Internacional de Haia. Em 1919, passou a advogar no Rio de Janeiro. Em 6 de maio de 1931, foi nomeado ministro do STF. Em 19 de novembro de 1937, foi eleito vice-presidente do Tribunal. Em virtude do Decreto-lei no. 2.770, de 11 de novembro de 1940, que transferiu para o presidente da República a nomeação do presidente do STF - até então eleito pelos seus pares -, Eduardo Espínola foi nomeado pelo Presidente Getúlio Vargas, em 19 de novembro de 1940, presidente do STF, cargo que exerceu até aposentar-se em 26 de maio de 1945" (RODRIGUES, 2002, p. 280). 
Hermenegildo de Barros, empossado em 1919, também se aposentou em 1937. Artur Ribeiro de Oliveira, empossado em 1923, faleceu em 1936. José Soriano de Sousa Filho, empossado em 1927, aposentou-se em 1932. Francisco Cardoso Ribeiro, empossado em 1927, faleceu em 1932. Firmino da Silva Whitaker, empossado em 1927, aposentou-se em 1934. Rodrigo Octávio Landgaard de Menezes, empossado em 1929, aposentou-se em 1934. Antes da promulgação da Constituição de 1934, ainda ingressariam no Supremo Manoel da Costa Manso (1933 a 1939), Octávio Kelly (1934 a 1942), Athaulpho Napoles de Paiva ${ }^{57}$ (1934 a1937), que substituíam Soriano de Souza, Rodrigo Octávio e Firmino Whitaker. No período, ainda tomariam posse como ministros do Supremo Tribunal Federal Armando de Alencar (1937 a 1941), Francisco Tavares da Cunha Melo (1937 a 1942), Carlos Maximilano Pereira dos Santos (1936 a 1941), Washington Osório de Oliveira (1938 a 1940), José Linhares (1937 a 1956), Frederico de Barros Barreto (1939 a 1963), Aníbal Freire da Fonseca (1940 a 1951), José de Castro Nunes (1940 a 1949), Orosimbo Nonato da Silva (1941 a 1960), Álvaro Goulart de Oliveira (1942 a 1950) e José Philadelpho de Barros e Azevedo (1942 a 1946).

A Carta de $1937^{58}$ estabelecia que os ministros do Supremo Tribunal Federal fossem nomeados pelo presidente da república com a aprovação do Conselho Federal, órgão que substituía o Senado Federal. Os ministros deveriam ser escolhidos entre os brasileiros natos, de notável saber jurídico e reputação ilibada, com mais de 35 anos e menos de 58 anos. Era competência do Supremo, processar e julgar originalmente: os ministros, o procurador-geral da República e os juízes das instâncias superiores; as causas e os conflitos entre a União e os Estados ou entre os Estados ${ }^{59}$; os litígios entre nações

\footnotetext{
57 Athaulpho de Paiva foi nomeado contrariamente à regra da idade mínima, uma vez que já tinha 69 anos, quando foi nomeado (COSTA, 2006, p. 74).

${ }^{58}$ O artigo 39 da Carta Constitucional de 1937 instituiu o Parlamento Nacional, que seria o órgão principal do Legislativo e se reuniria durante quatro meses por ano. No entanto, o artigo 180 definiu que o Presidente da República poderia legislar por Decretos-leis enquanto o Legislativo não se reunisse. Essa prática permeou todo o Estado Novo, uma vez que o Parlamento não foi de fato instituído.
}

${ }^{59} \mathrm{O}$ artigo 184 da Carta de 1937 determinou que os Estados deveriam permanecer na posse dos territórios onde exercessem jurisdição, de tal modo que seriam vedadas quaisquer reivindicações territoriais entre eles. No $\S 1^{\circ}$. do artigo 184 , ficava estabelecido que seriam extintos os litígios sobre limites entre os Estados, ainda que em andamento ou pendentes de sentença no Supremo Tribunal ou em juízo arbitral. Com isso, era eliminada do Supremo a competência de decidir sobre os limites entre os Estados, tão importante durante a República Velha (COSTA, 2006, p. 77). Um caso bastante discutido durante a Primeira República foi o dos limites interestaduais de Santa Catarina e Paraná. O Estado de Santa Catarina propôs, em 1900, uma ação ordinária pedindo que o Estado do Paraná fosse compelido a reconhecer e respeitar os limites entre esse 
estrangeiras e a União ou os Estados; os conflitos de jurisidição entre juízes de diferentes tribunais; o habeas corpus, em certas circunstâncias; a execução de sentenças nas causas de competência originária. Além disso, era competência do Supremo julgar ações rescisórias e, em recurso ordinário, as causas em que a União fosse parte, bem como as decisões de última instância denegatórias de habeas-corpus. Também era competência do Supremo julgar, em recurso extraordinário, as causas decididas pelas justiças locais em única ou última instância, (i) quando a decisão fosse contra tratado ou lei federal sobre cuja aplicação existisse dúvida, (ii) quando houvesse questionamento sobre a vigência ou a validade de lei federal, (iii) quando houvesse questionamento sobre a validade de lei ou o ato dos governos locais em face da Constituição, ou da lei federal e o tribunal local julgasse válida a lei ou o ato impugnado, (iv) quando os Tribunais de Apelação dessem interpretações diferentes da lei federal.

O Supremo manteria o papel de intérprete da Constituição, mas com as limitações impostas pelo regime do Estado Novo. De acordo com o art. 96 da Carta de 1937: "Só por maioria absoluta de votos da totalidade dos seus juízes poderão declarar a inconstitucionalidade de lei ou de ato do Presidente". Tal dispositivo reproduzia o art. 170 da Constituição de 1934, com a diferença de que em vez de "ato do Poder Público" como a constituição anterior, a Carta de 1937 falava em "ato do Presidente da República" (BATALHA, 1957, p. 90).

De um modo geral, durante o regime do Estado Novo, o Supremo Tribunal Federal ficava bastante esvaziado de suas mais importantes funções. No artigo 170 da Carta Constitucional de 1937, determinava-se que, durante o estado de emergência:

\footnotetext{
"não podiam os juízes e tribunais conhecer dos atos praticados em virtude dele, isto é, detenções, desterros para outros pontos do território nacional,
}

estado e o autor, definidos pelos rios Saí, Negro e Iguaçu, bem como a restituição de quaisquer territórios que, além desses marcos, estivessem sob a posse do Estado do Paraná. A demanda transitou durante 18 anos no Supremo Tribunal Federal. O caso foi resolvido, entretanto, por acordo firmado pelos dois estados em 20 de outubro de 1916, quando foram estabelecidos os limites da região contestada. O acordo foi aprovado pelo Congresso Nacional e publicado pelo decreto legislativo nº. 3304, de 3 de agosto de 1917 (BARBOSA 1961, pp. 145-147). Após o Acordo entre Paraná e Santa Catarina, o Supremo Tribunal passou a "cozinhar em água fria" as causas de limites entre os estados, ou destes com a União, até que a matéria foi retirada de sua competência pela Constituição de 1934 (RODRIGUES 1991a, p. 4). 
residência forçada em determinadas localidades do mesmo território, com privação da liberdade de ir e vir, e outros atos expressamente autorizados pela mesma Constituição como convenientes à manutenção da ordem pública, do princípio de autoridade de qualquer ponto do território nacional".

Esses são apenas alguns dos elementos que ajudam a entender como o Governo Vargas conseguiu neutralizar o Supremo Tribunal Federal, transformando-o em uma instituição frágil e com quase nenhum poder. Assim, ao contrário de Roosevelt com a Suprema Corte, Getúlio Vargas não teria que se preocupar com essa instituição no desenho de seu jogo político. Esse traço é extremamente importante para a compreensão de como os cenários em que se desenvolveram a sociological jurisprudence e o realismo jurídico norte-americanos eram completamente distintos daquele em que foi produzido o "realismo jurídico brasileiro".

Descritas as particularidades distintas dos cenários jurídicos dos dois países, passo, então, a apresentar o contexto histórico em que se desenvolvolveu a inserção da questão social no ordenamento jurídico brasileiro. 


\section{CONTEXTO HISTÓRICO BRASILEIRO}

No Brasil, já existiam grupos operários desde o final do século XIX, mas diante da questão servil $^{60}$ que preocupava a burocracia estatal do Império, a questão social não foi alçada ao centro do debate ${ }^{61}$. O Brasil, como último país do mundo a abolir a escravidão, também atrasaria a inserção da questão social como pauta do debate político nacional. Durante a República Velha ou Primeira República, havia se consolidado o projeto liberal e o laissez-faire econômico havia se materializado juridicamente com o Código Civil de 1916. A propriedade privada, a liberdade individual (frente ao poder do Estado) e a autonomia dos Estados eram garantias primordiais para boa parte dos tribunais brasileiros. Se durante o Império, os escravos eram tratados como propriedade, durante a Primeira República, a relação de trabalho ou era inserida na linguagem jurídica como relação contratual de locação de serviços ${ }^{62}$ ou sequer era considerada uma relação jurídica, mas uma simples continuação do regime servil, como muitas vezes eram qualificadas as relações de trabalho dos empregados domésticos.

\footnotetext{
60 “O Brasil havia praticamente acabado de deixar o regime escravocrata e ainda não disciplinara o novo sistema de trabalho livre. Era ainda uma sociedade rural, com a grande maioria da população vivendo nos campos ou em cidades pequenas. Achava-se em vigor ainda o Livro IV das Ordenações, Títulos 28 a 35 , a respeito de criados de servir, estabelecendo soldadas mínimas (por ano de serviço), mas voltados a uma espécie de relação de trabalho familiar, dos achegados aos senhores ou amos. Nada da relação de trabalho industrial e capitalista. Assim é que esses novos trabalhadores, que não são nem os criados (tutelados dentro de um sistema senhorial amo-criado), nem escravos nem trabalhadores livres de ofício regulamentado, encontram-se num limbo em que vigoram as liberdades do mercado e do contrato. No final do século XIX, embora já fossem uma força viva nas cidades grandes, o Brasil não dera atenção ao tema, pois estava ainda resolvendo a "questão servil'” (LOPES, 2002a, pp. 375-376).
}

61 Francisco Calheiros Ferreira afirmou que, embora as reformas institucionais brasileiras em torno da questão social tenham sido tardias, isso não significa que o país não tenha vivenciado esse problema desde o século XIX. De acordo com o autor: "O fato de o Estado brasileiro ter (...) tardiamente criado órgãos destinados a dirimir conflitos trabalhistas coletivos ou individuais, não significa que o país os tenha conhecido também mais tarde. Não. Ao contrário, o Brasil, desde o início da expansão européia, sentiu na pele o quão intensos eram os embates do mundo do trabalho. Em primeiro lugar devido à própria escravidão, que vigorou desde a chegada dos europeus até 13 de maio de 1888, fenômeno histórico estudado à saciedade, fruto permanente de violentos conflitos, impossíveis de conciliar a não ser por força das armas (...). Mas, em segundo lugar, muito antes da industrialização urbana que daria início ao moderno direito laboral, não nos podemos olvidar do ocorrido durante todo o século passado no que tange à imigração européia destinada à agricultura, sobretudo à lavoura do café” (FERREIRA, 1993, p. 142).

62 “O Tribunal de Justiça de São Paulo, em decição de 13 de agosto de 1915, exigia para a prova de serviços domésticos um contrato formal: 'Não se fez prova alguma de contrato de locação de serviços e se trabalho a autora teve em casa do réu, o réu, por seu turno, deu-lhe moradia, alimentou-a, assistiu-a em moléstias, etc.' (Revista dos Tribunais, apelação n 7.283)" (LOPES, 2002, p. 375). 
Durante a Primeira República, os poucos debates em torno da inserção da questão social no ordenamento jurídico passavam pelo Código Civil de 1916. Desse modo, as primeiras tentativas de inserir a questão social no debate jurídico brasileiro estavam relacionadas a esse código. A questão social, entretanto, viria a ser inserida no ordenamento jurídico, durante a Era Vargas, em um processo que teve que passar à margem desse código ${ }^{63}$. Os diferentes matizes ideológicos que dominaram os dois períodos ficariam registrados no modo como esse debate foi conduzido. Entre 1889 e 1930, dominou o pensamento "fiel ao individualismo jurídico" (GOMES, 2006, p. 33), enquanto, entre 1930 e 1945, apresentava-se, ao menos no discurso, a questão social como pauta central do pensamento jurídico. Nesse embate entre estado liberal e estado de bem-estar social, duas questões foram preponderantes: (i) a regulação dos contratos de trabalho (ou contratos de locação de serviços ${ }^{64}$ ) e (ii) a regulação da interpretação jurídica. Para analisar como se deu esse processo, examinarei, inicialmente, as mudanças que se deram em torno da regulação dos contratos de trabalho e, posteriormente, as transformações em torno da interpretação jurídica reguladas pela legislação.

${ }^{63}$ Esse debate já havia se iniciado nos projetos legislativos que antecederam a elaboração do Código Civil e que adentraria a Era Vargas. Orlando Gomes publicou, em 1958, o livro Raízes Históricas do Código Civil, tratando das tentativas de inserção da questão social nos projetos que geraram o código de 1916 e da forma como tais propostas foram rechaçadas pelos juristas brasileiros: "foram apresentados vários projetos de lei, que visavam à proteção do trabalhador, notadamente quando vítima de acidente de trabalho. $\mathrm{O}$ primeiro, de autoria do deputado Medeiros e Albuquerque, foi justificado em sessão de 3 de setembro de 1904 (...). Quatro anos depois, o deputado Gracho Cardoso, na sessão de 22 de agosto de 1908, enviou à Mesa da Câmara um projeto de lei em que renovava a iniciativa de Medeiros e Albuquerque (...). Outro projeto de lei, de autoria do deputado Wenceslau Escobar, é apresentado, no mesmo ano (...). Nenhum, porém, tem andamento. Outra tentativa se faz em 1915. É o senador Adolfo Gordo quem apresenta novo projeto de lei sobre acidentes do trabalho, insistindo na adoção de medidas inspiradas na doutrina do risco profissional. Esse projeto continuava em discussão quando foi promulgado o Código Civil. Verifica-se, pois, que, no período de elaboração do Código Civil, algumas tentativas para introduzir a legislação social foram feitas através de projetos legislativos sobre a matéria de acidentes de trabalho, nos quais perpassa o sopro das novas idéias que conquistavam terreno nos países mais adiantados da Europa. Mas esse movimento não exerceu qualquer influência no Código Civil que se elaborava simultâneamente. A mentalidade dominante conservase fiel ao individualismo jurídico, mais consentâneo, então, com o grau de desenvolvimento das forças produtivas do país" (GOMES, 2006, pp. 32-33).

${ }^{64}$ Orlando Gomes tratou também da 36. ${ }^{a}$ Reunião da Comissão Especial, realizada em 11 de dezembro de 1901, que discutiu o capítulo sobre a locação de serviços: “A mentalidade dominate na época transfundia-se com tanta objetividade na regras codificadas no capítulo da locação de serviços, que nenhum a traduz com nitidez maior. Não só na ausência de qualquer medida de proteção aos trabalhadores, mas no tratamento desigual que dispensa ao locatário e ao locador, beneficiando sempre ao primeiro, o Código Civil consagrou interesses de classe, que o marcaram daquele 'burguesismo' a que se referia Bevilácqua” (GOMES, 2007, pp. 43-44). 
A questão social - O desenvolvimento industrial periférico brasileiro e a efervescência social - A regulação dos contratos de trabalho

Nas primeiras décadas do século XX, a questão social havia sido tratada como um "fenômeno exepcional e episódico" (COHN, 2000, p. 387) e, embora na República Velha já houvesse leis esparsas que garantiam alguma proteção ao trabalhador ${ }^{65}$, foi somente na Era Vargas que ocorreu a legitimação da questão social via regulamentação das relações de trabalho. Com isso, formalizava-se o "estatuto da cidadania para determinados segmentos sociais, enquadrando-o juridicamente num aparato que reunia e articulava legislação trabalhista, legislação sindical e legislação previdenciária" (COHN, 2000, p. 392).

Desse modo, a revolução ou o golpe de 1930 significou uma importante mudança em relação ao modo como a "questão social" seria tratada no Brasil ${ }^{66}$. A partir de então, ao menos enquanto projeto de Estado, a "questão social" não deveria mais ser tratada como "caso de polícia" ${ }^{67}$, como havia sido considerada durante a República Velha, mas "deveria agora ser 'resolvida' mediante concessões de parte da nova elite política, antes que as pressões de baixo pudessem forçar mudanças mais básicas” (SKIDMORE, 1975, p. 33).

${ }^{65}$ Durante o Império, exitiram as associações privadas de proteção social, como a Sociedade Musical de Benemerência (1834) e a Sociedade de Animação da Corporação dos Artífices (1838), e alguns programas públicos, como o Montepio do Exército (1827) e o Montepio Geral da Economia (1835). A Lei $\mathrm{n}^{\circ}$ 3.397/1888 criou caixas de socorro garantindo pequenas assistências em casos de doenças e morte dos empregados das estradas de ferro. A tendência positivista que dominava a República levou à elaboração de alguns projetos de lei sobre o trabalho urbano. Em 25 de dezembro de 1889, Teixeira Mendes enviou ao Marechal Deodoro da Fonseca um projeto resultante da consulta feita a 400 operários. O programa abordava o "fim do serviço de empreitada, 7 horas efetivas de trabalho, descanso aos domingos e feriados, 15 dias de férias, recebimento de salários em caso de moléstia; depois de 7 anos, o operário não poderia ser demitido; o inválido receberia ordenado" (CARONE, 1975, p. 242). O projeto, no entanto, não se tornou lei. O Decreto $\mathrm{n}^{\circ} 10.269$ de 20 de julho de 1889 estabeleceu fundos de pensões pagos aos funcionários da Imprensa Nacional (BOSCHETTI, 2006, p. 11). Na República Velha, houve transformações importantes, como a lei de amparo às vítimas de acidente de trabalho (Lei Adolfo Gordo, apresentada em 1915, mas editada em 1919), a lei que instituía as caixas de aposentadorias e pensões para os ferroviários (Lei Elói Chaves, de 1923) e a lei que disciplinava o trabalho do menor (hoje, criança e adolescente). O Decreto $n^{\circ}$ 5.128/1926 autorizava a criação do Instituto de Previdência a Assistência Social dos Funcionários Públicos (IPASE).

66 "Se o avanço dos direitos políticos após o movimento de 1930 foi limitado e sujeito a sérios recuos, o mesmo não se deu com os direitos sociais. Desde o primeiro momento, a liderança que chegou ao poder em 1930 dedicou grande atenção ao problema trabalhista e social. Vasta legislação foi promulgada, culminando na Consolidação das Leis do Trabalho (CLT), de 1943” (CARVALHO, 2007, p. 110).

${ }^{67}$ O governo de Arthur Bernardes foi o período em que essa forma de tratar a questão social foi mais evidente. $\mathrm{O}$ estado de sítio que vigorou durante a maior parte de seu mandato era justificado pela necessidade de controlar as agitações do movimento tenentista e do movimento operário. Foi em seu governo que o dia $1^{\circ}$ de maio, data símbolo dos movimentos operários de todo mundo, foi declarado feriado nacional. Tratava-se de uma tentativa de esvaziar o caráter revolucionário da data. 
Por meio do "populismo", ocorreria a "ativação política" de setores populares anteriormente marginalizados, invocados "muito mais como um povo portador de exigências de justiça individual do que como cidadãos" (O’DONNELL, 1986, p. 20).

Para compreender esse processo é necessário entender a relação entre o tardio crescimento industrial brasileiro e as fórmulas encontradas pelo Estado nacional para controlar o proporcional aumento das pressões por reformas que definissem regras para as relações de trabalho, seja do ponto de vista da intitucionalização das associações e sindicatos, seja do ponto de vista do estabelecimento de garantias aos trabalhadores.

O crescimento da indústria e do operariado, entre 1870 e 1940, pode ser dividido em grandes fases: (i) a primeira, iniciada em 1870, foi freada pela crise financeira de 1897, quando muitas fábricas fecharam e outras reduziram sua produção; (ii) a segunda, com a retomada de seu impulso em 1900, novamente diminuindo a produtividade e a ocupação de mão-de-obra com a crise de 1913 (com dispensa de 50\% dos operários); (iii), a terceira iniciou-se com a Primeira Guerra Mundial, que, apesar de ter criado dificuldades a setores dependentes da importação, reduziu drasticamente a concorrência com os produtos industrializados estrangeiros (entre 1915 e 1917, foram criadas em São Paulo 323 indústrias), e encerrou-se em $1923^{68}$, quando a indústria européia recuperou-se da guerra; (iv) a quarta fase de crescimento industrial iniciou-se em 1931, no auge da depressão econômica internacional (iniciada com a crise norte-americana de 1929), e durou até o final da Segunda Guerra Mundial (SIMÃO, 1981, pp. 16-17).

Desse modo, percebe-se que, após 1930, ocorreu um processo de intensa transformação no cenário econômico, desencadeado pela crise de 1929. Os produtos que sustentavam a vida econômica brasileira, em particular o café ${ }^{69}$, perderam significativo valor econômico, o que impôs uma drástica redução nas exportações. O desequilíbrio nas contas externas levou a um rígido controle cambial, o que causou um forte declínio das

68 "O período imediatamente posterior à Primeira Guerra Mundial caracterizou-se por uma grande ofensiva de investimentos norte-americanos em nosso país. Esse acontecimento assinala não somente um novo aspecto de nossas relações internacionais, como também marca outra fase no processo de industrialização" (LIMA, 1976, p. 340).

69 "A cotação da libra-pêso de café tipo Santos-4, que se mantivera desde 1924 acima de 20 centavos de dólar norte-americano, oscilará depois da crise em torno de 10, baixando mesmo para menos de 8 depois de 1938 . O preço do café somente se recuperará no correr e sobretudo depois da II Guerra Mundial” (PRADO, 1970, p. 291). 
importações. Com isso, houve um significativo crescimento da produção de consumo interno, tanto agrícola quanto industrial ${ }^{70}$.

Simultaneamente às fases de crescimento industrial estavam as mobilizações operárias. As primeiras greves operárias ${ }^{71}$ no Brasil ocorreram na década de $1880^{72}$, em especial, a partir de 1888, durante a primeira fase de crescimento industrial. Entre $1901 \mathrm{e}$ 1914, houve 81 registros de greves na Capital e 38 em cidades menores, a maioria delas concentradas em apenas um estabelecimento ${ }^{73}$. Entre 1915 e 1929, durante a terceira fase de crescimento industrial, ocorreram 46 greves em São Paulo, 42 em estabelecimentos isolados, 20 em setores econômicos, uma generalizada e uma geral ${ }^{74}$ (SIMÃO, 1981, p. 101). Nessa segunda metade da República Velha, destacou-se a Greve Geral (de junho a julho) de $1917^{75}$, que, sob influência anarquista e anarco-sindicalista, ocorreu em São Paulo e foi uma das mais importantes manifestações do operariado urbano.

\footnotetext{
70 "A grave crise que sofria seu sistema tradicional de fornecedor de matérias-primas e gêneros tropicais resultava no progresso de sua nova economia voltada para necessidades próprias" (PRADO, 1970, p. 292)

${ }^{71}$ A formação do proletariado brasileiro deu-se, em um primeiro momento, a partir do recrutamento de mãode-obra estrangeira: imigrantes europeus que, apesar de majoritariamente provindos de regiões menos desenvolvidas, como o sul italiano, detinham certa experiência industrial. Inicialmente, essa imigração européia dirigiu-se ao campo, em especial ao cultivo do café. Com o processo de urbanização e industrialização, passaram progressivamente para as cidades (PINHEIRO, 1975, p. 86). "O governo mudara a sua posição em relação ao imigrante estrangeiro. Durante o século XIX e até a Primeira Guerra Mundial, o imigrante era bem-vindo e subsidiado. Havia necessidade de substituir os escravos e abastecer de mão-deobra as lavouras de café". Depois da guerra, o estrangeiro passou a ser visto como agitador e corruptor do operariado nacional. "O governo tentou criar animosidade entre o operariado nacional e o de origem estrangeira, acusando o último de privar o primeiro de seus empregos. A lei de sindicalização de 1931 continha um dispositivo que obrigava as empresas a contratar um mínimo de dois terços de operários nacionais" (CARVALHO, 2007, pp. 119-120).
}

${ }^{72}$ Em 1880, oito engenheiros de uma ferrovia suspenderam seus trabalhos como protesto à instauração de um processo administrativo (SIMÃO, 1981, p. 96).

${ }^{73}$ Em São Paulo, a primeira greve aconteceria em 1890, declarada por funcionários da seção de remessa de um jornal em função de uma redução de salários. Em 1906, uma greve de ferroviários transformou-se em um ensaio de greve geral. Nesse período, havia a Federação Operária, que tentava mobilizar os trabalhadores em greves generalizadas, tendo obtido sucesso em 1907 e 1912 (SIMÃO, 1981, pp. 96-98).

${ }^{74}$ De acordo com Boris Fausto, teriam ocorrido três greves gerais no país durante esse período: "Dentre as três greves gerais do período, a de junho/julho de 1917 em São Paulo permaneceu mais forte na memória histórica" (FAUSTO, 2003, p. 300)

75 Boris Fausto descreve o alcance da Greve Geral de 1917: "Começando por duas fábricas têxteis, ela abrangeu praticamente toda a classe trabalhadora da cidade, em um total de 50 mil pessoas. Durante alguns dias, os bairros operários do Brás, da Mooca e do Ipiranga estiveram em mãos dos grevistas. O governo mobilizou tropas, e a Marinha mandou dois navios de guerra para Santos". O Comitê de Defesa Proletária tinha como principais pautas de reivindicações: (i) o aumento de salário, (ii) a proibição do trabalho de 
No entanto, após 1920 houve uma grande repressão aos movimentos grevistas, como a prévia expulsão de estrangeiros cuja conduta fosse qualificada como nociva à segurança nacional ou à ordem pública. Tais medidas de polícia e repressão, associadas às dificuldades de organização, diminuíram significativamente o número e a intensidade dos movimentos operários e as mobilizações grevistas (FAUSTO, 2003, pp. 300-302). Além dos movimentos anarquistas, também existia o chamado "sindicalismo amarelo" 76, que servia aos propósitos do governo de buscar formas de neutralização do movimento operário e de controle sobre a mão-de-obra (KAREPOVS, 2006, p. 24). Não parece coincidência que, entre 1930 e 1937, um período de intenso crescimento industrial, mas permeado pela decretação do estado de sítio em 1935 (de novembro de 1935 até março de 1936) e do Estado Novo em 1937, tenham ocorrido apenas 59 greves em São Paulo e 31 no interior (SIMÃO, 1981, pp. 101-102), ou seja, um número proporcionalmente inferior aos períodos anteriores, marcados por um baixo crescimento industrial.

O concerto político promovido por Vargas foi capaz de conjugar a promoção de uma "cidadania regulada" 77 (SANTOS, 1978, p. 38) com um forte crescimento industrial. Aliado a isso, estavam os mecanismos de um Estado autoritário, como o controle dos meios de comunicação de massa ${ }^{78}$ e a repressão violenta aos “inimigos do Estado”. Desse

crianças com menos de 14 anos, (iii) a abolição do trabalho noturno de mulheres e adolescentes com menos de 18 anos, (iv) jornada de oito horas, com acréscimo de 50\% nas horas extras, (v) fim do trabalho aos sábados à tarde, (vi) garantia de emprego e (vii) respeito ao direito de associação. "Afinal chegou-se a um acordo com os industriais e o governo pela mediação de um Comitê de Jornalistas. Houve um aumento de salários, aliás, logo corroído pela inflação, e vagas promessas de se atender às demais reivindicações" (FAUSTO, 2003, pp. 300-302).

76 "Exemplo extremamente característico de tal tipo de sindicalismo era a Confederação SindicalistaCooperativista Brasileira (CSCB). Fundada em 1921, a CSCB teve como seu presidente e principal ideólogo Custódio Alfredo Sarandy Raposo, assumido discípulo do economista francês Charles Gide e do socialista Charles Fourrier" (KAREPOVS, 2006, p. 23).

${ }^{77}$ Conforme analisa Wanderley Guilherme dos Santos, ao descrever as políticas sociais após a Revolução de 1930 como uma "cidadania regulada": "Reconhece-se a existência civil do proletariado urbano, com direitos e interesses diferenciados legítimos, ao custo, todavia, de expulsar da participação no processo político, com o golpe de 1937, pela via eleitoral ao menos, a classe média - que pretendia ser a principal beneficiária de um sistema eleitoral limpo -, e de colocar sob controle político o movimento operário pela organização estatal de uma estrutura sindical centralizada e sob vigilância do governo" (SANTOS, 1978, p. 38).

${ }^{78}$ O artigo 122, § XV, da Carta de 1937, limitava a liberdade de imprensa: “com o fim de garantir a paz, a ordem e a segurança pública, a censura prévia da imprensa, do teatro, do cinematógrafo, da rádio-difusão, facultando a autoridade competente proibir a circulação, a difusão ou a representação. Autoriza, ainda, medidas repressivas para impedir manifestações contrárias à moralidade pública e aos bons costumes (...), do interesse público, bem-estar do povo e segurança do Estado". 
modo, diferentemente dos Estados Unidos, onde a legislação social apareceu como resultado da depressão econômica e da diminuição do número de ofertas de trabalho, no Brasil, essa legislação apareceu exatamente durante o período de maior crescimento industrial e de ofertas de trabalho de sua história até então. Isso é significativo à medida que explica os termos dessa regulação da relação entre capital e trabalho promovida pelo Estado brasileiro durante os anos 1930.

$\mathrm{Na}$ esfera do pensamento político, dominava o corporativismo, que fazia oposição tanto ao liberalismo, como ao socialismo. Abandonava-se a posição de ortodoxia liberal da Primeira República e adotava-se uma posição intervencionista declarada. Os poderes públicos deveriam atuar frente aos conflitos industriais e à questão social, regulamentando as relações entre os trabalhadores e os empresários, estabelecendo as modalidades associativas profissionais e definindo uma legislação de proteção ao trabalhador. Com o Decreto de 26 de novembro de 1930 foi criado, a partir de um desmembramento do Ministério da Agricultura (SKIDMORE, 1975, p. 33), o Ministério do Trabalho, Indústria e Comércio, que seria responsável pelo controle sobre as classes operárias e patronais (GOMES, 2007a, pp. 606-607).

Durante o Governo Provisório de Getúlio Vargas (1930-1934), especialmente sob a gestão de Joaquim Pedro Salgado Filho (1888-1950) no Ministério do Trabalho, Indústria e Comércio, editou-se uma seqüência de leis de regulamentação do trabalho e proteção ao operário urbano. Dentre essa legislação estavam os decretos que (i) estabeleciam a jornada de trabalho de oito horas, (ii) a organização do sistema de previdência social para estivadores, funcionários públicos e comerciários, (iii) proteção ao trabalho da mulher e do menor, (iv) regulamentação da jornada e das condições de trabalho para uma série de categorias, dentre as quais os bancários, empregados de farmácias, padarias e transportes terrestres (GOMES, 2007a, p. 607).

Apesar da existência de movimentos populares no país e da resistência dos empresários às transformações, a forma como o governo Vargas tratou a política trabalhista é uma significativa demonstração de uma ampla iniciativa que não derivou predominantemente das pressões de uma classe social, mas da ação do Estado. Os responsáveis pela nova legislação foram os ministros do Trabalho, como os gaúchos Lindolfo Collor (1890-1942) e Joaquim Pedro Salgado Filho (1888-1950), e técnicos 
ministeriais, como Oliveira Vianna e Waldir Niemeyer ${ }^{79}$, que não representavam os industriais ou os comerciantes; bem como participantes dos movimentos populares na Primeira República, como os advogados Evaristo de Morais Filho ${ }^{80}$ e Joaquim Pimenta (1886-1963) (FAUSTO, 2003, p. 336).

Em 1931, o Decreto n. 19.770 regulamentou a sindicalização dos empregados e empregadores $^{81}$, atribuindo às associações sindicais o direito de defender perante $o$ Governo e o Ministério do Trabalho os interesses econômicos, jurídicos, higiênicos e culturais de todos os trabalhadores que exercessem "profissões idênticas, similares ou conexas". Em seu art. 9. ${ }^{\circ}$, o Decreto 19.770 estabelecia a unicidade sindical determinando que "cindida uma classe e associada em dois ou mais sindicatos, será reconhecido o que reunir maior número de associados". Havia a possibilidade de constituição de sindicatos por empresa, por indústria e por profissão.

Os empresários, representados principalmente pelo Centro Industrial do Brasil (posteriormente, Federação Industrial do Rio de Janeiro) e pela Federação das Indústrias do Estado de São Paulo (FIESP), tentavam por meio do Ministro Lindolfo Boeckel Collor (1890-1942) influenciar nas decisões relativas às mudanças na legislação social. Muitas vezes essas influências não se refletiam em aprovação de seus projetos, mas em adiamento de regulamentação de cunho social (GOMES, 2007a, pp. 610-611).

Em 1932, por meio do Decreto n. 21.396, eram instituídas as Comissões Mistas de Conciliação $^{82}$. Esse decreto, que iniciava a organização de uma justiça do trabalho no

79 Assistente-técnico do Ministério do Trabalho, Indústria e Comercio - Diretor da Seção do Departamento Nacional do Trabalho.

${ }^{80}$ Evaristo de Moraes Filho nasceu em 1914 e continua vivo.

81 A Constituição de 1891 , em seu artigo $72, \S 8^{\circ}$, garantia o direito de associação e reunião, que seria regulamentado pelo decreto de setembro de 1893, permitindo a fundação de associações religiosas, morais, artísticas e políticas. Em 1904, a Corporação Operária Cristã de Pernambuco reuniu 6 mil assinaturas para pedir ao Congresso a criação de uma legislação profissional operária. O projeto foi apresentado pelo deputado Joaquim Inácio Tosta, que, seguindo o modelo de Pernambuco, submetia a direção da corporação ao empregador. Em 1907, ficava instituído o sindicato profissional (CARONE, 1975, p. 243). No entanto, até a década de 1930, os acordos entre empregados grevistas e empregadores não tinham garantia legal, podendo ser rescindidos a qualquer momento (SIMÃO, 1981, p. 103). Tratava-se de um período em que as relações privadas entre empregadores e empregados não tinham a proteção do Estado.

${ }^{82} \mathrm{Na}$ exposição de motivos do projeto que se instituiria por meio do Decreto $\mathrm{n}^{\circ} 21.396$, Lindolfo Collor apresenta o objetivo do governo de constituir uma Justiça do Trabalho no Brasil: "Inspira-se o novo projeto nas tradições liberais do país e representa uma contribuição louvável para a solução conciliatória dos 
Brasil, enfrentou muitas críticas dos empresários, representados pela FIESP ${ }^{83}$, e de alguns juristas liberais, como Waldemar Ferreira ${ }^{84}$. No entanto, apesar das críticas, a criação das Comissões Mistas de Conciliação e Julgamento teve um significativo sucesso, embasando um projeto corporativista de Estado (FERREIRA, 1993, p. 189).

A partir de $1933^{85}$, uma espécie de sindicalismo independente passava a concorrer com o Ministério do Trabalho na organização das associações operárias. Para conter essa tendência, foi criado, em julho de 1934, pelo procurador do Ministério do Trabalho Oscar Saraiva (1903-1969), o Decreto $\mathrm{n}^{\circ}$ 24.694. Uma das principais mudanças trazidas pelo Decreto de 1934 foi o retorno à pluralidade sindical, reconhecendo-se os sindicatos que agrupassem um terço ou mais dos trabalhadores que exercessem atividades idênticas, semelhantes ou conexas.

conflitos do trabalho e para o seu julgamento arbitral, livremente aceito pelas partes. O julgamento conciliatório dos conflitos não entra nos âmbitos do projeto, porque ele deverá, logicamente, ser atribuído aos juizados de trabalho, a serem criados oportunamente. Por enquanto, ficamos apenas na conciliação dos conflitos e na instituição legal dos arbitramentos" (COLLOR, 1991, p. 150).

${ }^{83}$ O presidente e primeiro-secretário da FIESP, Luiz Tavares Alves Pereira e Horácio Lafer, escreveram um telegrama ao Minitério do Trabalho Indústria e Comércio, demonstrando a preocupação do empresariado paulista com o Decreto de 1932: "Tendo em apreço as graves agitações ocorridas no meio operário paulista e considerando que a serenidade ainda não voltou aos espíritos, e considerando ainda que o empenho de todos neste Estado, quer dos poderes públicos, quer da coletividade, é conjugar esforços no sentido da normalização de nossa vida política, social e econômica, fazendo um apelo ao patriotismo de Vossa Excelência no sentido de ser sustada provisoriamente em São Paulo a execução das leis sociais desse Ministério. O decreto criando as comissões mistas de conciliação, o que fixa as horas de trabalho e aquele que delimita a atividade da mulher, conquanto de alta finalidade humanitária e patriótica, exigirão modificações essenciais na entrosagem do trabalho fabril (...)" (CARONE, 1978, p. 230-231).

84 "Instituindo as Comissões Mistas de Conciliação o governo ditatorial legislou no vácuo. Criou um órgão
destinado a permanecer no acervo da sua elaboração legislativa, mais do que a prestar os serviços
relevantíssimos, que dele seriam de esperar (...). Se, realmente, nenhuma convenção coletiva de trabalho até a
data do Decreto n ${ }^{\circ} 21.761$, de 23 de agosto de 1932, se celebrara, o que não era proibido, antes permitido
pelo direito vigente, por se não ter feito sentir a sua necessidade, nenhuma depois dele, naquele ano, se
registrou no Ministério do Trabalho, Indústria e Comércio. Informações oficiais asseguram não ter tido o
instituto maior incremento nos anos posteriores. Apenas cinco se registraram em 1934: uma em Pernambuco,
uma no Espírito Santo, uma no Distrito Federal e duas no Rio Grande do Sul. Não passaram de meia dúzia as
registradas em 1935: uma do Maranhão, três de Pernambuco, uma da Bahia e uma de Mato Grosso"
(FERREIRA, 1983, pp. 97-98).

${ }^{85}$ Em 1933, era criada a Delegacia Especial de Segurança Pública e Social. 
A Constituição de $1934^{86}$ estabeleceu um novo marco constitucional sobre a questão social. No capítulo Da Ordem Econômica e Social, presente pela primeira vez em um texto constitucional brasileiro (elaborado no projeto substitutivo da "Comissão dos 26 " e mantido na Constituição promulgada), define-se a regulamentação do mercado de trabalho, estabelecendo-se um conjunto de direitos concernentes às condições de trabalho nas empresas e a benefícios de natureza previdenciária, bem como da autorização constitucional para se legislar sobre o salário mínimo (Anais da Assembléia Nacional Constituinte, vol. 10, p. 554) (GOMES, 2007a, p. 84).

Considerada por muitos como uma constituição de compromisso $^{87}$ e, por isso, bastante comparada à Constituição da República de Weimar, a Constituição de 1934 legitimava a questão social como prioridade do Estado e da sociedade. Um exemplo disso é que passava a ser dever do Estado garantir o amparo à infância, à maternidade, à saúde e à educação. Também se tornava dever das empresas contratar determinado número de funcionários analfabetos, fornecendo-lhes ensino primário.

Em poucos anos havia sido produzida uma imensa quantidade de diferentes legislações trabalhistas. Ao mesmo tempo, a repressão do Estado em torno das mobilizações sociais também aumentava. Em 1935, realizou-se, com o apoio da Aliança

\footnotetext{
${ }^{86}$ Muitas dessas reformas sociais da Constituição de 1934 eram reivindicações do movimento tenentista: "No capítulo sobre a ordem econômica e social, reconheceu os sindicatos e assegurou a pluralidade e 'a completa autonomia' dos mesmos. Salário mínimo, expediente de oito horas, salário igual para trabalho igual, repouso hebdomadário (aos domingos) remunerado, férias anuais, indenização ao trabalhador dispensado sem causa justa, reconhecimento das convenções coletivas de trabalho, assistência médica e sanitária, previdência social, amparo à maternidade e à infância, proibição de trabalho a menores de 14 anos, estas e outras reivindicações tenentistas foram instituídas na Constituição de 16 de julho de 1934. Quanto aos trabalhadores do campo, estabeleceu: 'o trabalho agrícola será objeto de regulamentação especial, em que se atenderá, quanto possível, ao disposto deste artigo: procurar-se-á fixar o homem no campo, cuidar da sua educação rural, e assegurar ao trabalhador nacional a preferência na colonização e aproveitamento das terras públicas'. E mandava que a União, com a colaboração dos Estados, promovesse 'a organização de colônias agrícolas, para onde serão encaminhados os habitantes de zonas empobrecidas que o desejarem, e os sem-trabalho" (MALTA, 1969, p. 73).

${ }^{87}$ A instabilidade constitucional do período estudado é atribuída, muitas vezes, à própria estrutura das Constituições brasileira de 1934 e de Weimar de 1919, denominadas, com frequiência, de "constituições de compromisso". Foram as considerações de Carl Schmitt, caracterizando a Constituição alemã de Weimar como uma constituição de compromisso, que influenciaram a posição da maioria dos juristas brasileiros na análise da Constituição de 1934 (e, posteriormente, a Constituição de 1946). Gilberto Bercovici ressalta que essa posição de Schimitt, embora influente, não era a única, muito menos consensual (BERCOVICI, 2003b, pp. 243-246). No entanto, foi essa idéia de constituição de compromisso, presente na obra de Carl Schmitt, autor interessado em combater a República de Weimar, que chegou aos juristas brasileiros, constituindo-se, em muitos casos, como um artifício importante na deslegitimação da Constituição de 1934. Parece ter sido esse o caso de Oliveira Vianna.
} 
Nacional Libertadora ${ }^{88}$ (ANL), a Convenção Nacional de Unidade dos Trabalhadores, cujo objetivo era criar a Confederação Unitária do Brasil. Em 14 de abril de 1935, foi criada a Lei de Segurança Nacional, que criminalizava qualquer tentativa de disseminar divisões de classe (art. 14), incitação à luta entre classes sociais (art. 15), bem como proibia o direito de greve aos funcionários públicos e aos trabalhadores em serviço público, ainda que sob contrato individual (art. 18, parágrafo único) (WERNECK VIANNA, 1976, p. 199). Em novembro de 1935, no Rio de Janeiro e no Nordeste (iniciou-se no Rio Grande do Norte), ocorreram os levantes da "Intentona Comunista" ${ }^{89}$. Naquele momento, entretanto, a ANL já havia perdido a maior parte dos seus integrantes, quando, quatro meses antes, havia sido declarada ilegal. A rebelião foi esmagada em poucos dias pelo governo ${ }^{90}$.

No final de dezembro, antes de entrar em recesso, o Congresso autorizou a prorrogação por 90 dias da Lei de Segurança Nacional e aprovou emendas constitucionais que permitiam a Vargas declarar "estado de guerra" e exonerar servidores públicos civis e militares considerados subversivos. O ministro da Justiça era Vicente Rao (1892-1978). O Decreto $\mathrm{n}^{\circ} 229$, de 11 de julho de 1935, determinou o fechamento da Aliança Nacional Libertadora (ANL) pelo período de seis meses (art. 29 da Lei ${ }^{\circ} 38$, de 4 de abril de 1935 Lei de Segurança Nacional), bem como determinou o cancelamento de seu registro civil, por considerá-la subversiva da ordem política e social ${ }^{91}$.

${ }^{88}$ A Aliança Nacional Libertadora (ANL) era uma frente popular organizada e chefiada por Luís Carlos Prestes, reunindo comunistas, sindicalistas e antifascistas para combater o integralismo (LEVINE, 2002, p. 69).

89 “'Os planos para uma insurreição no Brasil foram traçados em Moscou, em 1934, no curso de reuniões a que estiveram presentes uns poucos comunistas brasileiros e membros da cúpula do Comitern (Terceira Internacional)" (DULLES, 1985, p. 13).

${ }^{90}$ A imprensa noticiava documentos tidos como extremistas que tinham sido encontrados pela polícia e "os jornais falavam em 'novos planos comunistas', tais como o que foi descoberto em dezembro de 1935 e que previa 'o massacre de autoridades e populares numa igreja em Curitiba"” (DULLES, 1985, p. 15)

91 O Decreto foi examinado pelo Supremo Tribunal Militar, em 21 de agosto de 1935, a partir de um mandado de segurança (pedido $\mathrm{n}^{\circ}$ 111) impetrado pelo presidente da ANL, o comandante Hercolino Cascardo. O relator do caso foi o Ministro Artur Ribeiro. O pedido foi indeferido por unanimidade (COSTA, 1964, pp. 48-67). Foi utilizado como prova da atividade subversiva o fato de Luís Carlos Prestes (1898-1990) ser o presidente de honra da ANL e a presença de seu retrato na parede da associação. Carlos Maximiliano (1873-1960), procurador-geral da República, proferiu o seguinte parecer: "O chefe geral, respeitável sob todos os aspectos porque tem coragem das próprias convicções, é o único a declarar-se francamente comunista, não tirou nenhum proveito pessoal do triunfo de 1930, não teve, como outros, lugares altamente remunerados, o prazer em toda a sua plenitude. A influência com os respectivos corolários: Luís Carlos Prestes, na fase combativa, assombrou o País pela sua tática perigosa e espírito de sacrifício e renúncia" (SILVA, 1969, p. 205). No mesmo período, foi impetrado um mandado de segurança pelo advogado Luís 
Em 1937, intensificou-se o controle das mobilizações populares. No ano anterior, em 1936, haviam sido criados a Comissão Nacional para Repressão ao Comunismo e o Tribunal de Segurança Nacional ${ }^{92}$. O regime Vargas assumia sua face mais repressiva com a decretação do Estado Novo e apresentava essa face como forma de solucionar a questão social $^{93}$ (ao ponto de a Carta Constitucional de 1937 ter proibido a greve ${ }^{94}$ ). O modelo exigia o sindicato único e subordinado ao controle estatal, já que reconhecido como o representante de uma categoria profissional inteira. A pluralidade e a liberdade sindicais eram percebidas como insustentáveis.

Em $1^{\circ}$. de maio de 1943, era promulgada, pelo Decreto $\mathrm{n}^{\circ} 5452 / 1943$, a Consolidação das Leis do Trabalho (CLT), que além de definir o direito material (direitos e obrigações) das relações entre empregados e empregadores, regulamentava a Justiça do Trabalho, constituída por um Tribunal Superior da Justiça do Trabalho, Tribunais Regionais e Juntas de Conciliação e Julgamento. O ministro do Trabalho à época era Marcondes Filho e a Comissão autora do projeto havia sido composta pelos procuradores

Werneck em prol da União Feminina Brasileira, fechada ao mesmo tempo em que a ANL. "Dias depois, na Câmara, discursando a propósito de uma atitude das feministas norte-americanas, a deputada paulista Carlota Pereira de Queiroz defendeu os direitos econômicos e políticos da mulher. Seu ponto de vista, praticamnte, coincidia com o programa da União Feminina Brasileira" (SILVA, 1969a, p. 203).

92 O Tribunal de Segurança Nacional foi criado com o intuito de processar e julgar os presos na Intentona Comunista, dentre os quais estavam Luís Carlos Prestes, Harry Berger, Alan Baron e Rodolfo Ghioldi. Como era proibido pela Constituição de 1934 a criação de tribunais de exceção, o Tribunal de Segurança Nacional foi instituído como um órgão da Justiça Militar (COSTA, 2006, p. 87).

93 A institucionalização desse regime pela Constituição de 1937 era legitimada por uma série de juristas tidos como independentes. Francisco Cavalcanti Pontes de Miranda (1892-1979), ao escrever um texto denominado Visão Sociológica da Constituição de 1937, defendia as mudanças da Carta em relação à Constituição de 1934: "Diante da questão social, que exigia solução, a Constituinte de 1933-1934 satisfez-se com vagos preceitos programáticos, abrindo as possibilidades da prevenção e da repressão pela força, mas dentro de redes de uma legislação antiquada e sem os meios, para o Poder Executivo e para o próprio Poder Legislativo, de atacar, nas causas, os movimentos de subversão (...). Era o momento propício para a descoberta de uma fórmula que significasse estabilidade, progresso, evolução prudente e sistemática, enriquecimento e fortalecimento da Nação, sem sacrifício do pluripartidarismo, do sistema de codecisão, que herdamos da Europa e dos Estados Unidos da América. Em vez de procurá-la, a Constituinte de 1933-1934 se não tornou, para o futuro, impossível, para o Brasil, o pluripartidarismo, que somente invenção técnica genial poderia salvar, profundamente o sacrificou (...). Qual a atitude que teve, diante de tais problemas de importância capital, o legislador constituinte de 1937? Sem destruir a autonomia político-administrativa dos Estados-membros, deu às políticas estaduais o papel que devem ter, com inteira possibilidade de preencher as funções que os serviços estaduais e de segurança social lhe exigem, dentro dos quadros de uma legislação inspirada no interesse nacional (...)" (MIRANDA, 1938, pp. 19-20).

94 O art. 139 da Carta de 1937 estabelecia que: "A greve e o lock out são declarados recursos anti-sociais nocivos ao trabalho e capital e incompatíveis com os supremos interesses da produção nacional”. 
da Justiça do Trabalho Arnaldo Süssekind, Dorval Lacerda e J. Segadas Vianna (BATALHA, 1994, p. 41).

A edição da CLT apenas em 1943 fez com que houvesse uma constante associação pela historiografia brasileira entre as reformas sociais promovidas pelo governo Vargas e o período ditatorial do Estado Novo (1937-1945) ${ }^{95}$. No entanto, a historiografia mais recente, formada inclusive por novos "brasilianistas" norte-americanos como John French, tem desenvolvido a tese de que a maior parte das reformas legislativas sociais e trabalhistas teria ocorrido antes do golpe de estado de 1937. Para essa nova historiografia, a centralização corporativista pós Estado Novo apenas sistematizou as mudanças introduzidas no período revolucionário (1930-1934) e no período constitucional (19341937) e criou formas de executar medidas que já estavam consolidadas na doutrina e na legislação (FRENCH, 1991, p. 14). Essa tese é fortalecida quando se analisa que, ainda no período democrático, os juristas já viam a necessidade se consolidar a vasta legislação social brasileira. Em 1936, ao prefaciar o livro Consolidação das Leis Trabalhistas de Luís Pereira dos Santos, Oliveira Vianna tratou dessa grande quantidade de legislação esparsa, comparando-a às políticas sociais do New Deal:

\begin{abstract}
"Nossa legislação social, que é uma das mais avançadas e completas dentre as legislações congêneres latino-americanas, foi elaborada quase de um ímpeto, como uma febre legiferante. Não é de modo algum obra de um só indivíduo, nem mesmo de alguns técnicos do Ministério. É obra de muitos, surgiu de uma colaboração quase anônima de todos os interessados, patrões e empregados, principalmente (...) de uma forma ou de outra, podemos realizar, em cerca de quatro anos, a elaboração de todo este vasto complexo jurídico, que forma a legislação social vigente. Este vasto labor legislativo, operado em tão curto espaço de tempo, não tem paridade em nenhuma legislação do mundo, a não ser na da N.R.A. americana. Como quer que seja, a legislação social brasileira aí está. É
\end{abstract}

\footnotetext{
${ }^{95}$ Um fator que dificulta os estudos sobre a legislação trabalhista do período anterior ao Estado Novo é o fato de que o Ministro do Trabalho, Waldemar Falcão, ao mudar a sede da pasta, em 1938, determinou a eliminação do arquivo morto, desaparecendo toda a documentação relativa ao período entre 1930 e 1938 (COLLOR, 1991, p. 17; ARAÚJO, 1981, p. 15).
} 
um edifício enorme e impotente, a que falta sem dúvida (...) acabamento. Da sua vastidão, da sua complexidade, do seu valor, o presente volume permitirá uma apreciação de conjunto, e por isso mesmo, mais justa e segura. Não se diga que é demasiadamente copiosa ou abundante; porque não o é menos a dos outros povos mais adiantados do que nós. Basta lembrar que a política do New Deal americano exigiu a elaboração de mais de 600 códigos" (VIANNA, 1936, pp. 3-4).

De qualquer modo, mesmo entendendo que a maior parte da legislação social brasileira foi produzida durante o período anterior à ditadura do Estado Novo, não é possível deixar de perceber que esse processo de fortalecimento dos direitos sociais seguiu a lógica brasileira da "cidadania regulada" (SANTOS, 1978, p. 38).

Assim, conforme disse anteriormente, enquanto nos Estados Unidos a implantação, o reconhecimento e a institucionalização dos movimentos operários foram resultado da ação dos próprios trabalhadores em luta contra os empresários e contra o Estado, no Brasil, a formação de um sindicalismo de massas teve como seu principal interlocutor o próprio Estado (GOMES, p. 2007, p. 664). Esses foram elementos que definiram o modelo paternalista e populista de inserção da questão social na agenda do Estado brasileiro.

Os "fins sociais" da Lei de Introdução ao Código Civil de 1942 - uma pequena resposta à ortodoxia-liberal do Código Civil de 1916

Como se percebe, apesar de a questão social ter dominado a pauta jurídica durante a Era Vargas, não foi forte o bastante para ser inserida no Código Civil, a legislação liberal por excelência. Em vez de se alterar os artigos que tratavam da locação de serviços, reformando o Código Civil de 1916, foi necessário criar-se uma legislação própria para tratar dos contratos de trabalho, que culminou com a Consolidação das Leis do Trabalho de 1943. Desse modo, mesmo em meio a um regime de exceção, não se conseguiu reformar o código de Clóvis Bevilácqua, embora isso tenha sido tentado pelo Governo. 
Logo após a outorga da Carta Constitucional de 1937, Francisco Campos, então Ministro da Justiça, nomeou uma comissão com o objetivo de elaborar um projeto de reforma de todo o Código Civil. No entanto, apenas o projeto de reforma da Lei de Introdução ao Código Civil foi transformado em lei (Exposição de Motivos à Lei de Introdução ao Código Civil, assinada pelo Ministro Alexandre Marcondes Filho). A comissão era composta pelos ministros do Supremo Tribunal Federal Orozimbo Nonato (1891-1974) e José Philadelpho de Barros e Azevedo (1894-1951), bem como pelo Consultor-Geral da República Hahnemann Guimarães (1901-1980).

Antes da Lei de Introdução ao Código Civil de 1942, vigorava a Introdução ao Código Civil ${ }^{96}$, reformada em 1919, com 21 artigos (ESPÍNOLA, 1943, p. 7). O Decreto n. 4.657, de 4 de setembro de 1942, instituiu a Lei de Introdução ao Código Civil, tendo sido assinado pelo ministro Alexandre Marcondes Filho (1892-1974) ${ }^{97}$, que acumulava as pastas da Justiça e do Trabalho, e Oswaldo Euclides de Sousa Aranha (1894-1960). Na Exposição de Motivos do Anteprojeto de Código das Obrigações (1941), endereçada pelos

96 “O projeto Beviláqua propusera que se adotasse para a introdução o título, que lhe deu o legislador alemão: lei de introdução. No projeto revisto, embora se mantivesse numeração à parte, houve o propósito de fazê-la entrar no corpo do código, como título preliminar. A comissão revisora preferira a orientação do esboço de Teixeira de Freitas e do projeto de Felício dos Santos, e que era a do Código Napoleão. A comissão dos 21 deputados adotou a designação lei preliminar, como se encontrava no projeto Coelho Rodrigues. Por emenda do Senado, foi acolhida a epígrafe definitiva, ficando a Introdução fora do corpo do código, com a numeração separada, como fez o legislador italiano, com as 'disposições sobre a aplicação das leis em geral', que precedem o respectivo código civil. As matérias, a que se aplicam as normas e princípios da nossa Introdução, são as mesmas que constituem objeto das disposições italianas” (ESPÍNOLA, 1943, p. 7).

${ }^{97}$ O advogado formou-se em 1914 pela Faculdade de Direito de São Paulo. Após formar-se, exerceu o cargo de promotor público na capital paulista e tomou parte na fundação do Instituto dos Advogados de São Paulo. Em 1926, elegeu-se vereador em São Paulo pelo Partido Republicano Paulista (PRP). No ano seguinte, obteve uma vaga de deputado por seu estado no Congresso Nacional. Como membro da bancada do PRP, foi partidário da candidatura presidencial de Júlio Prestes nas eleições de março de 1930. Apesar de vitorioso no pleito, Júlio Prestes foi impedido de assumir a presidência em função do movimento armado deflagrado em outubro daquele ano, que levou Getúlio Vargas ao poder. Em 1932, deu apoio ao Movimento Constitucionalista, deflagrado em São Paulo contra o governo de Vargas. Com a derrota do movimento, afastou-se por alguns anos das atividades políticas. Após a instalação da ditadura do Estado Novo em novembro de 1937, foi nomeado vice-presidente do Departamento Administrativo do Estado de São Paulo (DAESP), órgão cuja finalidade era garantir o controle do governo federal sobre o estado de São Paulo, da mesma forma que se dava nos demais estados. Em dezembro de 1941, foi nomeado ministro do Trabalho por Vargas (...). Em julho de 1942, assumiu também a pasta da Justiça, passando a acumulá-la com a do Trabalho. Em maio de 1943, foi decretada pelo governo a Consolidação das Leis do Trabalho (CLT), que efetivava e, em alguns casos ampliava, a legislação social e trabalhista executada desde a subida de Vargas ao governo, em 1930. Em 1945, com a crescente pressão social pela democratização do país, foi encarregado por Vargas de elaborar um projeto que garantisse ao próprio regime a condução do processo de abertura política (...). Deixou o Ministério da Justiça em março de 1945, permanecendo na pasta do Trabalho até a deposição de Vargas" (www.cpdoc.fgv.br/nav_historia/htm/biografias/ev_bio_marcondesfilho.htm). 
membros da comissão ao Ministro da Justiça, Francisco Campos, em 24 de janeiro de 1941, deixou-se claro o seu papel de "mitigar os excessos do individualismo":

\begin{abstract}
"Recebendo a incumbência de proceder à revisão do Código Civil e tendo em mira a conveniência de atender às modificações operadas por leis posteriores, seguir as modernas tendências do direito, mitigar os excessos do individualismo, incompatíveis com a ordem jurídica dos tempos que correm, e reduzir a dualidade de princípios aplicáveis aos negócios civis e mercantis em prol da unificação de preceitos, que devam reger todas as relações de ordem privada" (NONATO, 1941, p. 51).
\end{abstract}

Em seu art. $5^{\circ}$., a LICC apresentava como elementos da aplicação da lei pelo juiz, os "fins sociais" da lei e o "bem comum": "Na aplicação da lei, o juiz atenderá aos fins sociais a que ela se dirige e às exigências do bem comum". O único artigo da LICC editada em 1916 e reformada em 1919 que tratava sobre o tema da interpretação era o art. $6^{\circ}$.: "A lei que abre exceção a regras gerais, ou restringe direitos, só abrange os casos que especifica". Asssim, não havia, antes da LICC de 1942, qualquer tentativa de se instruir os juízes sobre como deveriam interpretar a lei. Com a LICC de 1942 e, especialmente, com o artigo $5^{\circ}$., houve uma tentativa de se modificar, a partir da lei, a forma liberal de se aplicar o direito.

Os efeitos sobre a cultura jurídica dessa tentativa de transformar a estrutura do direito a partir da LICC de 1942 serão estudados no último capítulo desse trabalho, dedicado ao exame da cultura jurídica brasileira do período entre guerras. Assim, o que fiz, até aqui, foi apenas introduzir os elementos que compuseram o cenário jurídico daquele período, com destaque para o conteúdo "questão social" e para a estrutura "aplicação do direito". Esses, por sua vez, simétricos ao conteúdo crítico à ortodoxia liberal e à estrutura combativa ao formalismo jurídico.

Montado o cenário, posso iniciar a próxima fase deste trabalho, apresentando a cultura jurídica norte-americana que se formou durante o período entre guerras e, posteriormente, a cultura jurídica brasileira que se formou, no mesmo período, a partir de 
um processo que envolveu, dentre outros fatores, a deglutição antropofágica do Progressive Legal Thought norte-americano. 


\section{CAPÍTULO III - PROGRESSIVE LEGAL THOUGHT}

Durante a primeira metade do século XX, em especial no período entre as duas grandes guerras, uma geração de juristas norte-americanos desenvolveu um modelo de pensamento jurídico crítico (progressivism) que ficou conhecido como realismo/funcionalismo jurídico. Seus principais representantes foram Roscoe Pound ${ }^{98}$ (1870-1964, Sociological Jurisprudence), Benjamin Nathan Cardozo ${ }^{99}$ (1870-1938, Suprema Corte), Jerome Frank (1889-1957), Karl Llewellyn (1893-1962), Robert Lee Hale $^{100}$ (1884-1969), Walter Wheeler Cook (1873-1943), Arthur Linton Corbin (18741967), Louis Dembitz Brandeis ${ }^{101}$ (1856-1941, Suprema Corte), Harlan Fiske Stone ${ }^{102}$

${ }^{98}$ Roscoe Pound nasceu em Lincoln, Nebraska. Bacharelou-se e obteve o grau de Ph.D em botânica pela Nebraska University. Foi durante 11 anos diretor do Nebraska Botanic Survey. Após longa experiência em botânica, Pound concluiu dois dos três anos do curso de direito da Harvard University, mas não se bacharelou. Retornou a Nebraska para exercer a profissão. Pouco tempo depois, começou a lecionar direito na Nebraska University. Após dois anos de ensino, foi nomeado reitor. Aos 37 anos de idade, deixou o cargo para lecionar em Chicago e em Northwestern, chegando a Harvard três anos mais tarde. Trabalhou na Harvard University durante 37 anos até se aposentar (MORRIS, 2002, p. 543).

${ }^{99}$ Benjamin Nathan Cardozo, de origem judaica, filho de um ministro da Suprema Corte do Estado de New York, Albert Cardozo, foi nomeado pelo Presidente Hoover ministro da Suprema Corte norte-americana em 1932, em vaga aberta com a aposentadoria de Holmes. Antes disso, havia sido advogado e juiz (desembargador) do Tribunal de Apelação do Estado de New York desde 1917 (POSNER, 1993, pp. 1-3; RODRIGUES, 1992, p. 108). Suas decisões (votos) mais significativas foram Wood v. Duff-Gordon, 222 N.Y. 88, 118 N.E. 214 (1917), Canadian Industrial Alcohol Co. V. Dunbar Molasses Co., 258 N.Y. 194,179 N.E. 383 (1932), College and De Circco v. Schweizer, 221 N.Y. 431, 117 N.E. 807 (1917), Glanzer v. Shepard, 233 N.Y. 236, 135 N.E. 275 (1922), Wagner v. International Ry, 232 N.Y. 176, 133 N.E. 437 (1921), Imperator Realty Co. V. Tull, 228 N.Y. 447, 127 N.E. 263 (1920), Meinhard v. Salmon, 249 N.Y. 458, 164 N.E. 545 (1928), Jacob \& Youngs, Inc. v. Kent, 230 N.Y. 239, 129 N.E. 889 (1921), MacPherson v. Buick Motor Co., 217 N.Y. 382, 111 N.E. 1050 (1916), Ultramares Corp. v. Touche, 255 N.Y. 170, 174 N.E. 441 (1931), H.R. Moch Co. v. Rensselaer Water Co., 247 N.Y. 160, 159 N.E. 896 (1928), Kerr S. S. Co. v. Radio Corp. of America, 245 N.Y. 284, 157 N.E. 140 (1927), Adams v. Bullock, 227 N.Y. 208, 125 N.E. 93 (1919), Ostrowe v. Lee, 256 N.Y. 36, 175 N.E. 505 (1931), Berkovitz v. Arbid \& Houlberg, Inc., 230 N.Y. 261, 130 N.E. 288 (1921), Shepard v. United States, 290 U.S. 96, 104 (1933), Reed v. Allen, 286 U.S. 191 , 209 (1932) (voto dissidente), Berkey v. Third Avenue Ry., 244 N.Y. 84, 155 N.E. 58 (1926), Cullings v. Goetz, 256 N.Y 287, 176 N.E. 397 (1931), Palko v. Connecticut, 302 U.S. 319 (1937), Schechter Poultry Corp. v. United States, 295 U.S. 495, 554 (1935), Carter v. Carter Co., 298 U.S. 238, 327-328 (1936) (voto dissidente), Gully v. First National Bank, 299, U.S. 109 (1936), United States v. Swift \& Co,, 286 U.S. 106 (1932) (POSNER, 1993, pp. 92-124).

${ }^{100}$ Robert Lee Hale (1884-1969) estudou economia e direito em Harvard (undergraduate) e, então, ingressou no doutorado em Columbia, disposto a unificar o direito e a economia. Após isso, tornou-se Professor de Columbia (KALMAN, 2005, p.19).

${ }^{101}$ Brandeis, de origem judaica, era um importante advogado trabalhista quando, em 1916, foi nomeado ministro da Suprema Corte norte-americana por Woodrow Wilson. Em sua atuação como ministro, Brandeis utilizou-se de sua experiência na advocacia, envolvendo a análise de dados estatísticos e empirismos, para 
(1872-1946, Suprema Corte), Felix Frankfurter (1882-1965, Suprema Corte), Felix Solomon Cohen ${ }^{103}$ (1907-1953) e Thurman Arnold (1891-1969). Buscaram romper com o modelo jurídico concebido pela geração anterior, conhecida por old school/mechanical jurisprudence $^{104}$ ou escola conceitualista (liderada por Christopher Columbus Langdell, 1826-1906, que enfrentava críticas de Oliver Wendell Holmes Jr., 1841-1935, e John Chipman Gray, 1839-1915). Esses autores buscaram, tanto no terreno universitário como no terreno da prática jurídica (advocacia e adjudicação), reformular o modo de se pensar e de se aplicar o direito.

A própria definição do que foi e quando começou o realismo jurídico norteamericano não é consensual entre os historiadores. Em geral, atribui-se esse movimento ao conjunto de pensamentos jurídicos produzidos por professores de Columbia e Yale entre 1920 e 1930 (Karl Llewellyn e Robert Lee Hale, 1884-1969, de Columbia e Walter Wheeler Cook, 1873-1943, e Arthur Linton Corbin, 1874-1967, de Yale). Entretanto, tal definição exclui do movimento as influências que antecederam a esses autores, dificultando ainda mais a elaboração de uma delimitação precisa do que foi o Realismo Jurídico nos Estados Unidos. O Realismo Jurídico norte-americano, em grande parte, continuou o projeto do Progressive Legal Thought de atacar as tentativas dos autores clássicos (Classical Legal Thought) do final do século XIX de criar um modelo que separasse rigorosamente o direito da política, representando esse direito como neutro e natural (HORWITZ, 1992, pp. 169-170).

O Progressive Legal Thought combatia a idéia de que um raciocínio desenvolvido silogisticamente, a partir de regras e precedentes obtidos com base em fatos de casos particulares, conduziriam a uma decisão correta. O primeiro a esboçar esse pensamento

mensurar a constitucionalidade das leis (CORWIN, 1932, p. 17). Foi considerado por Hall como um dos dez maiores ministros da Suprema Corte norte-americana.

${ }^{102}$ Stone, ex-reitor da Universidade de Columbia, foi nomeado ministro da Suprema Corte norte-americana em 1925.

${ }^{103}$ Felix Cohen era filho do filósofo do direito Morris R. Cohen, autor de Law and the Social Order. Essay in Legal Philosophy.

104 “A metáfora da Constituição 'machine', inspirada em uma visão mecanicista-newtoniana, substituiu-se a idéia de uma 'living Constitution', sustentada por uma abordagem historicista e evolutiva do direito" (CASALINI, 2006, p. 281). 
hostil à compreensão do direito como um problema abstrato de lógica foi Oliver Holmes, que, ainda jovem advogado em Boston, publicava The Common Law. Holmes dizia-se avesso a todos os grandes princípios morais, dentre os quais incluía o "direito natural". Para ele, somente existiria a incidência da força pública por meio da instrumentalidade dos tribunais. Alguns anos mais tarde, John Chipman Gray, um professor de direito da Harvard University, apontava o papel individual do juiz em oposição à idéia de uma lógica do direito auto-aplicável que decidisse casos particulares. Após Holmes e Gray, Louis D. Brandeis e, um pouco mais tarde, Felix Frankfurter, afirmariam que os juízes deveriam conscientemente considerar os prováveis resultados sociais de suas decisões (PURCELL, 1988, p. 360).

Dentre as características mais marcantes do realismo jurídico pode-se destacar: o forte ceticismo em relação (i) ao formalismo normativista, (ii) ao conceitualismo e (iii) à possibilidade mecanicista de determinação das decisões judiciais. O movimento acentuou, assim, a noção de indeterminação do direito em seu sentido e aplicação e apontou a necessidade de utilização de elementos externos ao direito para a explicação fática e teórica da prática jurídica.

As contribuições do realismo jurídico para o pensamento norte-americano ${ }^{105}$ podem ser observadas (i) no ensino jurídico, com a acentuação da interdisciplinaridade e da compreensão social, política e econômica dos problemas jurídicos; e (ii) na teoria do direito, tendo influenciado movimentos como o Law and Society Association (empirismo e ceticismo) (GARTH, 1998, pp. 409-472), o Law and Economics (judges' law-making power) e o Critical Legal Studies (apresentação dos conflitos e ambigüidades e a função

\footnotetext{
105 “A teoria jurídica americana contemporânea também tem sido poderosamente afetada pelo movimento realista. A orientação empírica e o ceticismo relativo ao domínio nas relações sociais de 'regras de papel' são características do movimento da Law and Society; a impaciência com o raciocínio doutrinário e a defesa do poder dos juízes de interpretar a lei são idéias predominantes dentre os autores da Law and Economics; a aspiração de expor 'lacunas, conflitos e habilidades' na ordem jurídica e a fascinação com as funções ideológicas da doutrina jurídica manifestada na maioria dos artigos dos Critical Legal Studies - todos são rastreáveis até as argumentações dos Realistas" (HORWITZ, 1993, p. xiv). "Contemporary American legal theory has also been powerfully afected by the Realist movement. The empirical orientation and the skepticism concerning the grip on social affairs of 'paper rules' characteristic of the Law and Society movement; the impatience with doctrinal reasoning and the insistence upon judges' law-making power that infuses most Law and Economics scholarship; the aspiration to expose 'gaps, conflicts, and ambiguities' in the legal order and the fascination with the ideological functions of legal doctrine manifested in most Critical Legal Studies writings - all are traceble to the contentions of the Realists" (HORWITZ, 1993, p. xiv original).
} 
ideológica da doutrina jurídica) (HORWITZ, 1993, p. xiv; BILLIER, 2005, p. 251; PAULA, 2006, p. 12).

Esse grande "movimento progressista" do direito norte-americano tinha como base a filosofia pragmatista ${ }^{106}$ de William James ${ }^{107}$ (1842-1910), Charles Sanders Peirce (18391914) e John Dewey (1859-1952). De acordo com o próprio James, o método da filosofia pragmatista era:

\footnotetext{
"a atitude de olhar além das primeiras coisas, dos princípios, das 'categorias', das supostas necessidades; e de procurar pelas últimas coisas, frutos, conseqüências, fatos (...). As teorias, assim, tornam-se instrumentos, e não respostas aos enigmas, sobre as quais podemos descansar" (JAMES, 1967, p. 48).
}

Essa influência dos pragmatistas fez com que um grande número de intelectuais norte-americanos, em diversas áreas de conhecimento, passasse a adotar o empirismo, o experimentalismo e o relativismo como técnicas para solucionar problemas e para direcionar a produção de conhecimento. Funcionalismo e behaviorismo tornaram-se palavras-chave de uma linha de pensamento que valorizava a psicologia experimental

\footnotetext{
106 O termo "pragmatismo" foi introduzido no discurso filosófico por Charles Peirce no artigo "Como tornar claro nossas idéias", publicado pela revista Popular Science Monthly (janeiro) (JAMES, 1967, p. 44). William James afirmava que, apesar de não gostar do nome "Movimento Pragmático" considerava-se um de seus integrantes e o considerava um conjunto de tendências que sempre teriam existido na filosofia, mas que teriam se conscientizado de sua missão coletiva, razão pela qual teria se mostrado repleto de contradições: "O movimento pragmático, chamado assim - não gosto do nome, mas, aparentemente, é tarde demais para mudá-lo - parece ter se precipitado algo subitamente das alturas. Certo número de tendências que sempre existiram na filosofia, tornaram-se todas de uma só vez cônscias de si mesmas coletivamente e de sua missão em conjunto; e isso ocorreu em tantos países e de tantos pontos de vista diferentes, que daí resultou muito pronunciamento desajustado" (JAMES, 1967, p. 23). Para James, o nome mais adequado para esse movimento seria "empirismo radical": "Digo 'empirismo' porque se contenta em considerar as suas mais seguras conclusões concernentes a realidades como hipóteses capazes de modificação no curso da experiência futura; e digo 'radical' porque trata a doutrina do monismo em si como uma hipótese, e, diferente em muito do empirismo pela metade, que é corrente sob o nome de positivismo ou agnoticismo ou naturalismo científico, não afirma dogmaticamente o monismo como alguma coisa com a qual toda experiência seja obrigada a enquadrar-se" (JAMES, 1967, pp. 225-226).

${ }^{107}$ William James, irmão do romancista Henry James e contemporâneo de Oliver Wendell Holmes Jr., nasceu em New York. Após concluir o curso da Escola de Medicina de Harvard, tornou-se professor de filosofia.
} 
como base para diversas outras ciências. A partir disso, somente o conhecimento produzido sobre bases experimentais seria válido. A priori, tudo seria desprovido de provas e improvável. Como conseqüência disso, ampliava-se o relativismo ético e uma certa abitrariedade, uma vez que se abriam os limites da fundamentação jurídica. No início dos anos 1930, influentes antropólogos, como Ruth Benedict, Carl Becker e Charles Beard ${ }^{108}$ contribuíam para a confirmação dessa tendência relativista. Segundo esses autores, os julgamentos históricos não poderiam ser verdadeiramente objetivos, pois tinham como base apenas evidências parciais, desprovidas de uma avaliação experimental (PURCELL, 1988, p. 359).

Essa importância do estudo sobre o comportamento humano e o comportamento dos juízes (behaviorismo) na obra dos realistas foi destacada pelos próprios juristas, como no texto de Karl Llewellyn, A Realistic Jurisprudence - The Next Step (1930):

\footnotetext{
"Os aspectos mais significativos (eu não digo que são os únicos significativos) das relações entre a lei e a sociedade encontram-se no campo do comportamento e essas palavras assumem importância seja por causa e na medida em que são comportamentos ou por causa e na medida em que refletem ou' influenciam de modo evidente outro comportamento. Tal afirmação parece repetir o óbvio, pois sua verdade é evidente. Por tudo isso, ela reverte e desarranja toda a abordagem tradicional do direito, tornando-se a teoria dominante em seu topo. A abordagem tradicional ocorre em termos de palavras; é centralizada em palavras; apresenta a maior dificuldade em ir além das palavras. Se nada for dito sobre comportamento, a assunção tácita é que as palavras refletem comportamento e, se forem palavras do Estado de direito, influenciam o comportamento de modo tão efetivo e preciso que se adequam perfeitamente àquelas palavras" (LLEWELLYN, 1930, pp. 442-443 tradução livre $)^{109}$.
}

\footnotetext{
${ }^{108}$ Em 1927, Charles e Mary Beard lançaram The Rise of American Civilization.

109 "The most significant (I do not say the only significant) aspects of the relations of law and society lie in the field of behavior, and that words take on importance either because and insofar as they are behavior, or because and insofar as they demonstrably reflect or influence other behavior. This statement seems not worth
} 
O diálogo dos filósofos pragmáticos com os juristas era intenso. Por exemplo, John Dewey, em 1935, com o texto Liberalism and Social Action, utilizou uma decisão de Brandeis na Suprema Corte para reforçar sua idéia de que o liberalismo precisa "assumir a responsabilidade de tornar claro que a inteligência é um bem, um ativo social, que se reveste de função tão pública quanto é, concretamente, sua origem na cooperação social" (DEWEY, 1970, p. 69). Além disso, Dewey aproveitou para criticar a maioria conservadora da Suprema Corte, combatida internamente por uma minoria da qual Brandeis fazia parte ${ }^{110}$.

No entanto, uma diferença importante entre os filósofos pragmatistas, como James e Dewey, e o realismo jurídico, é quanto ao modelo de ceticismo adotado. Enquanto os filósofos desenvolveram um ceticismo metodológico, os juristas parecem ter transportado esse ceticismo para o próprio conteúdo decisório. Isso pode ser percebido especialmente na obra de Karl Llewellyn e, talvez, ajude a explicar muitas das críticas ${ }^{111}$ sofridas pelo realismo jurídico norte-americano e, em especial, pelo realismo pós-Llewellyn ${ }^{112}$.

making, its truth is absurdly apparent. For all that, it reverses, it upsets, the whole traditional approach to law. It turns accepted theory on its head. The traditional approach is in terms of words; it centers on words; it hás the utmost difficulty in getting beyond words. If nothing be said about behavior, the tacit assumption is that the words do reflects behavior, and if they be the words of rules of law, do influence behavior, even influence behavior effectively and precisely to conform completely to those words" (LLEWELLYN, 1930, pp. 442443 - original).

${ }^{110}$ De acordo com Dewey: "Brandeis, juiz da Suprema Corte Americana, julgando um caso de lei que restringia realmente a liberdade de expressão, pode defendê-la com palavras mais eloqüentes que quaisquer outras jamais pronunciadas. Disse ele: 'Aqueles que conquistaram a nossa independência acreditaram que o fim do Estado era fazer os homens livres para desenvolver as suas faculdades e que em seu governo as faculdades deliberativas deviam prevalecer sobre o arbítrio. Queriam a liberdade como um fim e como um meio (...) que graças a elas, a discussão daria, normalmente, proteção adequada à contradisseminação de doutrinas prejudiciais; que a maior ameaça à liberdade é um povo inerte; que a discussão pública é um dever político; e que este devia ser o princípio fundamental do governo americano'. Este é o credo do liberalismo combatente. Mas a questão que desejo levantar liga-se ao fato de que essas palavras partiram de uma opinião divergente da minoria da Suprema Corte dos Estados Unidos. A função pública do pensamento e das palavras livres do indivíduo aí estão claramente reconhecidas nas palavras citadas. Mas a verdade contida nessas palavras esbarra num obstáculo: o velho hábito de defender a liberdade de pensamento e de expressão como algo inerente aos indivíduos, à parte e mesmo em oposição aos reclamos sociais" (DEWEY, 1970, pp. 6869).

111 Willian Twining questionou a forma como essas críticas foram feitas. O principal pesquisador sobre a obra de Karl Llewellyn escreveu que: "deve-se fazer distinção entre o que um jurista disse e como o que foi dito foi interpretado e usado. Por exemplo, a tese recente de Bruce Ackerman de que o Realismo proporcionou aos advogados um meio de lidar com a legislação New Deal ao dar a eles licença para intuir o seu caminho para a justiça é uma hipótese mais histórica sobre a recepção do realismo pelos advogados 
No campo jurídico ${ }^{113}$, os realistas dialogaram com juristas/teóricos do direito europeu, em especial com a Escola de Direito Livre de François Gény ${ }^{114}$ (1861-1938), Méthode d'Interpretation et Sources en Droit Privé Positif (1899), bem como com a sociologia do direito de Eugène Ehrlich, Grundlegung der Soziologie des Rechts (1913) e Die Juristische Logik. Essa influência pode ser percebida especialmente na obra de Benjamin Cardozo ${ }^{115}$ e Roscoe Pound, que elaboraram uma versão norte-americana da tese

praticantes do que sobre o que qualquer Realista em particular realmente declarou. De maneira semelhante, as críticas de H.L.A. Hart's em relação ao ceticismo jurídico e à suposta teoria da previsibilidade do direito, bem como a defesa do Estado de Direito por John Dickson e a tomada de decisão à partir de princípios pode ter envolvido interpretações historica e textualmente dúbias dos originais; apesar de suas críticas poderem, por si próprias, ser argumentos válidos e esclarecedores. Mostrar porque alguma crença, proposição ou teoria é errada no nível da análise, não implica necessariamente o compromisso com uma alegação que qualquer pessoa já tiver feito de tal crença como uma questão de fato histórico. Poucos homens têm um papel a desempenhar na teoria jurídica. O que é lamentável é a tendência de tratá-los como personagens históricos, atribuindo-lhes os papéis de vilões e não os de parceiros" (TWINING, 1985b, pp. 340-341 - tradução livre). Versão original: "one must distinguish between what a jurist said and how what was said was interpreted and used. For example, Bruce Ackerman`s recent thesis that Realism provided legal practioners with a means of coping with New Deal legislation by giving them license to intuit their way to justice is more a historical hypothesis about the reception of Realism by practicing lawyers than about what any particular Realist actully said. Similarly, H.L.A. Hart's criticisms of rule-skepticism and the alleged prediction theory of law or John Dickson's defense of the Rule of Law and principled decisionmaking may have involved historically or textually dubious interpretations of the originals; yet their criticisms may in themselves be both valid and illuminating as arguments. Showing why some belief, proposition, or theory is wrong at the level of analysis does not necessarily imply commitment to a claim that anyone ever subscribed to such a belief as a matter of historical fact. Straw men have a role to play in legal theory. What is regrettable is the tendency to treat them as if they were historical characters and to give them leading roles as vilains rather than walk-on parts" (TWINING, 1985b, pp. 340-341 - original).

${ }^{112}$ Em The Concept of Law, Herbert L. A. Hart examinou o realismo jurídico como ceticismo em relação às regras. De acordo com o professor inglês, o "cético acerca das regras é por vezes um absolutista desapontado" (HART, 1994, p. 152). Para demonstrar a falha da teoria jurídica dos céticos, no caso, os realistas norte-americanos, Hart cita um trecho de um famoso texto de Llewellyn, The Bramble Bush - on our Law and its Study: "as regras são importantes na medida em que nos ajudam a predizer o que os juízes farão. Tal é a única importância, à parte do fato de que constituem lindos brinquedos" (HART, 1994, p. 152). No entanto, essa crítica de Hart já podia ser percebida em alguns discursos contemporâneos aos realistas e mesmo um pouco antes do debate entre Llewellyn (KLRM) e Pound. Para muitos, o discurso decisionista não era mais do que mero absolutismo jurídico.

${ }^{113}$ Parte-se, aqui, da definição de campo jurídico de David Trubeck que se utilizou do conceito de campo social de Pierre Bordieu para definir campo jurídico como uma ampla articulação de instituições e práticas por meio das quais a lei é produzida, interpretada e incorporada às tomadas de decisões na sociedade (TRUBECK, 1993, p. 31).

${ }^{114}$ Gény, com suas críticas à Escola da Exegese e ao monopólio da lei, antecipou o que mais tarde viria a se tornar a nova tendência alemã de oposição ao legalismo e à jurisprudência dos conceitos.

115 Apenas como ilustração do papel que François Gény e Eugène Ehrlich exerceram sobre alguns autores realistas, contei quantas vezes os textos dos dois autores foram citados na principal obra de Benjamin Cardozo, The Nature of the Judicial Process: Gény foi citado 16 vezes e Ehrlich foi citado sete vezes. Ao analisar o juiz como legislador, Benjamin Cardozo faz uma comparação entre as mudanças provocadas por Holmes na forma de se conceber o papel do juiz no common law e as mudanças pregadas pela teoria de Gény na forma de se compreender o papel do juiz no sistema do civil law: "Não foi só em nosso sistema de 
da interpretação subjetiva ${ }^{116}$ de Gény. Na verdade, pode-se dizer que Roscoe Pound foi para a sociologia do direito norte-americano o que Ehrlich foi para a sociologia do direito europeu $^{117}$.

Essa relação entre o progressive legal thought norte-americano e as obras de Gény e Ehrlich explicam-se tanto pela (i) inserção da sociologia como elemento essencial para a análise do direito, como também pela (ii) simpatia com que esses autores e, em especial, Ehrlich, vêem o papel dos juízes e tribunais para a modernização e adaptação do direito (LOPES, 1997, p. 162). No caso de Benjamin Cardozo, essa valorização do papel do julgador para transformar o direito encaixava-se perfeitamente tanto ao seu modelo teórico de juiz, descrito em The Nature of the Judicial Process (1921), como a sua atuação como ministro da Suprema Corte norte-americana que buscava rever os entendimentos já cristalizados por esse tribunal em relação a temas como a questão social.

common law que essa concepção abriu caminho. Mesmo em outros sistemas nos quais a lei escrita limita com mais rigor o poder da iniciativa judicial, percebe-se no ar um desenvolvimento semelhante. Em toda parte vêse uma ênfase crescente na analogia entre a função do juiz e a função do legislador. Posso citar como exemplo François Gény, que desenvolveu essa analogia com ousadia e poder sugestivo" (CARDOZO, 2004, p. 87). "Not only in our common law system hás this conception made its way. Even in other systems where the power of judicial initiative is more closely limited by stature, a like development is in the air. Everywhere there is growing emphasis on the analogy between the function of the legislator. I may instance François Gény who has developed the analogy with boldness and suggestive power" (CARDOZO, 1991, p. 119).

${ }^{116}$ A tese da interpretação subjetiva pode ser compreendida como uma tentativa de recuperação da intenção do legislador, ou seja, a vontade do autor do texto. Os meios para se compreender essa "intenção autêntica do legislador" englobam desde a análise da própria letra da lei ou de seus anteprojetos ao contexto histórico da edição da norma em seus aspectos econômicos, sociais e morais (BILLIER, 2005, p. 274).

117 "Dean Roscoe Pound nos Estados Unidos e Eugène Ehrlich na Europa são as duas grandes personalidades fundadoras da sociologia jurídica” (BILLIER, 2006, p. 280). 


\section{A CRÍTICA AO CONCEITUALISMO JÚRIDICO NORTE-AMERICANO (CLASSICAL LEGAL THOUGHT OU MECHANICAL SCHOOL) - O PAPEL DE OLIVER WENDELL HOLMES JR.}

Entre 1870 e 1905, predominou no pensamento jurídico norte-americano o que ficou conhecido como pensamento jurídico clássico. O pensamento econômico dominante era o laissez-faire. Assim como na maior parte do Ocidente, a seleção natural (evolução natural) de Charles Darwin e, especialmente, o determinismo social de Herbert Spencer tiveram grande influência no pensamento político e jurídico a partir da segunda metade do século XIX. A obra Social Statics, de Spencer, publicada na Inglaterra em 1851, teve sua primeira edição norte-americana em 1865 e teve como um de seus maiores divulgadores Edward Youmans, fundador da Popular Science Monthly (IRONS, 1999, p. 236).

Buscava-se garantir um pensamento jurídico neutro, diferenciando-se o raciocínio jurídico do raciocínio político (HORWITZ, 1992, p. 27). A cultura jurídica norteamericana da segunda metade do século XIX moldava-se a partir de grandes dicotomias, tais como meios e fins; procedimento e substância; público e privado (HORWITZ, 1992, p. 16). Essa estrutura permitiu ao pensamento clássico explicar o conteúdo jurídico a partir de duas esferas: "uma pública, coercitiva, representada pelo direito tributário, constitucional, e, principalmente, pelo direito penal e pelo direito regulatório; e uma privada, nãocoercitiva, que abarcava a responsabilidade civil, o direito dos contratos, o direito de propriedade e o direito comercial, pensada como uma expressão jurídica que deveria estar livre das interferências políticas" "118 (HORWITZ, 1992, p. 11 - tradução livre). O que estava em questão nessa separação radical entre direito público e direito privado era a elaboração de um pensamento jurídico preponderantemente abstrato e essencialmente neutro, reforçando-se a explicação do direito a partir de conceitos pretensamente despolitizados, mas que traziam consigo a defesa da ortodoxia liberal.

Defendia-se, desse modo, a transformação do estudo do direito em algo mais científico e menos político. No entanto, essa tentativa de neutralização do direito, a partir

\footnotetext{
118 "One of the most powerful tendencies in late-nineteenth-century law was the move to create a sharp distinction between what was thought to be a coercive public law - mainly criminal and regulatory law - and a non-coercive private law of tort, contract, property, and commercial law, designed to be resistant to the dangers of political interference" (HORWITZ, 1992, p. 11 - original).
} 
de sua formalização, passava necessariamente pela preservação das teses do liberalismo econômico no interior do conteúdo jurídico. A mais influente personalidade do universo do direito nesse momento era provavelmente Christopher Columbus Langdell (1826-1906) e a voz dissonante era a de Oliver Wendell Holmes Jr. (1841-1935).

Christopher Columbus Langdell (1826-1906), o principal autor do movimento conceitualista $^{119}$ e idealizador do ensino jurídico a partir do case method ${ }^{120}$ (Harvard University), escreveu em 1871, em sua obra Law of Contracts, que "o direito, considerado como uma ciência define-se a partir de princípios doutrinários determinados" (LANGDELL, 1871). No período em que foi dean da Harvard Law School (HLS), entre 1870 e 1895, Langdell foi responsável por estabelecer um novo modelo de ensino jurídico, de tal modo que seu trabalho é tido como o marco inicial do ensino jurídico moderno norte-americano. No entanto, embora seu método de ensino jurídico tenham sido fundamental para o que se tornou a cultura jurídica norte-americana, sua defesa do formalismo e do conceitualismo jurídico tinham como premissa a defesa de um direito despolitizado, que, sob essa roupagem acabava por reforçar a defesa da ortodoxia liberal.

Em oposição ao liberalismo econômico e ao formalismo jurídico, representados por Langdell, estava o pensamento social norte-americano (Progressivel Legal Thought). Seus principais interlocutores nas mais diferentes áreas seriam John Dewey, Thorstein Veblen, Oliver Wendell Holmes, Charles A. Beard e James Harvey Hobson (WHITE, 1961, pp. 7$8)^{121}$.

119 Além de Langdell, outro autor bastante influente nesse período teria sido o juiz Thomas Cooley. Além de suas decisões na Corte de Michigan, sua obra mais conhecida, Constitutional Limitations (1868), foi determinante para consolidar no período uma cultura jurídica refratária a um modelo de Estado Regulador. Outro jurista significativo para a estabilidade do modelo laissez-faire norte-americano, teria sido o Justice da Suprema Corte Samuel F. Miller. Uma ilustração da postura adotada pela Suprema Corte em relação ao tema pode ser verificada no caso Pollock v. Farmer's Loan and Trust CO. (1895). Nesse caso, a Suprema Corte decidiu que ao Estado seria vedada a redistribuição da riqueza por meio do regime de tributação (HORWITZ, 1992, p. 19).

${ }^{120}$ Uma análise crítica (ou mesmo satírica) do case method pode ser vista em KALMAN, 1995, pp. 771-773.

121 "O instrumentalismo é a doutrina de Dewey que defende que idéias são planos de ação e não espelhos da realidade; que dualismos de todos os tipos são fatais; que o método da inteligência é a melhor maneira de resolver problemas; e que a filosofia deve se liberar para a engenharia social. 2 - $\mathrm{O}$ institucionalismo de Veblen é uma doutrina que insiste na importância de estudar empiricamente as conexões entre instituições econômicas e outros aspectos de cultura. Ele rejeita a economia política clássica como abstrata de uma maneira que supostamente a condene, e oferece em seu lugar uma teoria programática de desenvolvimento econômico em termos de duas instituições fundamentais: os engenheiros e o sistema de preços. 3 - O 
Oliver Wendell Holmes Jr. ${ }^{122}$ (1841-1935) era professor da Harvard University quando foi nomeado juiz (desembargador) da Suprema Corte do Estado de Massachusetts, onde permaneceu por 20 anos. Em 1902, foi nomeado, por Theodore Roosevelt, ministro da Suprema Corte dos Estados Unidos da América (posse em 1903), onde permaneceu por 30 anos (1903-1931). Sua primeira obra a receber certa notoriedade pela comunidade jurídica foi Kent's Commentaries. A principal obra de Holmes foi The Common Law, lançada em 1881. Outro texto seu de grande relevância para a teoria do direito foi The Path of the Law, publicado em 1897 (HORWITZ, 1992, p. 109). Foi qualificado por parte considerável da historiografia jurídica dos Estados Unidos como o "maior teórico do direito norte-americano" 123 (HORWITZ, 1978, p. 47) e "talvez o juiz norte-americano mais famoso" 124 (GREY, 1995, p. 19). Seu papel na definição da hermenêutica

realismo de Holmes consiste em rejeitar a visão de que a lei é uma entidade abstrata presente como um significado de uma determinada estrutura, esperando para ser encontrada por um juiz. Ao contrário, ela é, em uma grande extensão, feita pelo juiz. 4 - A contribuição mais séria de Beard ao padrão é um desenvolvimento e elaboração do ponto de vista de Madson no décimo documento federalista, segundo o qual a facção é o grande problema da sociedade democrática moderna. Beard, portanto, olha com Madson para forças econômicas subjacentes que determinam a aceleração da vida social e pede que o historiador represente o processo de civilização como um todo. 5 - James Havery Robson foi o representante americano culto do ponto de vista de que a história não é apenas uma crônica do passado, mas uma arma pragmática para explicar a presença e controlar o futuro do homem, uma doutrina que ele denominou como 'nova história' em contradição às recitações de intriga real e militar" (WHITE, 1961, pp. 7-8 - tradução livre). "Instrumentalism is Dewey's doctrine wich holds that ideas are plans of action, and not mirrors of reality; that dualisms of all kinds are fatal; that the method of intelligence is the best way of solving problems; and that philosophy ought to free itself to social engineering. 2. Veblen's institutionalism is a doctrine wich insists upon the importance of studying empirically the connections between economic institutions and other aspects of culture. It rejects classical political economy as abstract in a way that supposedly condemns it, and it offers instead a programmatic theory of economic development in terms of two fundamental institutions: the engineers and the price system. 3. Holmes' realism consists in rejecting the view that law is an abstract entity present as the meaning of a given structure, waiting to be found by a judge. On the contrary it is, in great measure, made by the judge. 4. Beard's most serious contribution to the pattern is a development and elaboration of Madison's view in the tenth Federalist paper, the view that faction is the great problem of modern democratic society and that is the source of faction. Beard, therefore, looks with Madson for underlying economic forces that determine the acceleration of social life, and urges the historian to chart the process of civilization as a whole. 5. James Harvey Robson was the literate American representative of the view that history is not merely a chronicle of the past, but rather a pragmatic weapon for explaining the present and controlling the future of man, a doctrine wich he named the 'new history' in contradistinction to recitations of royal and military intrigue” (WHITE, 1961, pp. 7-8 - original).

${ }^{122}$ Oliver Wendell Holmes Jr. era filho de Oliver Wendell Holmes, importante médico e escritor de seu tempo.

${ }^{123}$ Tradução livre.

124 Tradução livre. 
constitucional norte-americana foi determinante ${ }^{125}$. Holmes acreditava que o "significado daquilo que chamamos de 'Constituição' - apesar do fato de que as palavras, como marcas em pergaminho cuidadosamente preservado nos Arquivos Nacionais, permanecem inalteradas - tinha sido na realidade em parte reconstruído por cada uma das gerações de leitores" (TRIBE, 2007, p. 5).

De um modo geral, Oliver Holmes deixaria duas importantes heranças ${ }^{126}$ para a próxima geração de juristas: (i) de um lado, a ruptura com o modelo da Corte do laissez faire; (ii) de outro, sua crença no papel dos tribunais como principais definidores do direito, o que pode ser resumido por uma conhecida frase de seu texto The Path of the Law: "as profecias do que os tribunais farão de fato, e nada mais pretensioso, são o que eu considero como lei" ${ }^{127}$ (HOLMES, 1897, p. 461).

\footnotetext{
${ }^{125}$ Em Missouri v. Holland, Holmes teria dito: "quando nós estamos lidando com palavras que constituem atos, como é o caso da Constituição dos Estados Unidos, temos que nos conscientizar de que elas foram trazidas à vida para desenvolver alguma coisa que possivelmente não tenha sido completamente prevista pelos seus dedicados progenitores. Foi suficiente para eles... a esperança de criar um organismo; isso levou um século e custou ainda a seus sucessores mais sangue e suor para provar que a nação tinha sido criada" 252 U.S. 416 (1920) (TRIBE, 2007, p. 5).

${ }^{126}$ Além de Holmes, há outros autores que foram imprescindíveis para a concepção do Progressive Legal Thought, tais como: James B. Thayer, autor de The Origin and Scope of the American Doctrine of Constitutional Law (1893), Roscoe Pound, autor de Liberty of Contract (1909) e Law in Books and Law in Action (1910) e John Chipman Gray, autor de The Nature and Sources of the Law (1909).

127 "The prophecies of what the courts will do in fact, and nothing more pretentious, are what I mean by the law" (HOLMES, 1897, p. 461).
} 


\section{A SOCIOLOGICAL JURISPRUDENCE E O REALISMO JURÍDICO NORTE- AMERICANO}

A principal divisão das linhas que geraram o realismo jurídico norte-americano deu-se entre dois seguidores das idéias de Oliver Wendell Holmes Jr. de distintas gerações: o jovem Karl Llewellyn (KLRM) ${ }^{128}$ e o velho Roscoe Pound. Pound seguia Holmes na busca por substituir a lógica jurídica formalista pelos estudos empíricos e históricos. Enquanto Holmes inaugurara na Suprema Corte o ceticismo em relação à existência de um "direito natural" ou de qualquer idéia absoluta de justiça, Pound discordava do conceitualismo e da lógica jurídica formalista do Classical Legal Thought, bem como das técnicas de ensino jurídico fundadas em Harvard por Langdell, inaugurando a sociologia jurídica nos Estados Unidos.

Foi exatamente a partir desse debate que o Realismo tornou-se uma escola de pensamento jurídico nos Estados Unidos. Em abril de 1930, Karl Llewellyn, então jovem professor da Faculdade de Direito de Columbia, publicou na Columbia Law Review seu artigo "A Realistic Jurisprudence - The Next Step", cunhando o termo "Realismo". Meses depois, Jerome Frank publicou seu livro Law an the Modern Mind, formulando o termo "Realismo Jurídico" ${ }^{129}$. Um ano depois (março de 1931), Roscoe Pound, que não só já era diretor (dean 1916-1936) da Faculdade de Direito de Harvard, como possuía reputação internacional de maior teórico do direito norte-americano desde Holmes, publicou no vol. 44 da Harvard Law Review, "The Call for a Realistic Jurisprudence", uma crítica ao Realismo Jurídico (HORWITZ, 1992, pp. 171; DUXBURY, 1995, p. 72). No número seguinte da Harvard Law Review, Llewellyn publicaria sua resposta às criticas de Pound,

128 Em 1935, Llewellyn publicou um artigo na Columbia Law Review, chamado Holmes. O primeiro parágrafo do texto demonstra o objetivo de Llewellyn: "Os homens refletem as instituições. Os homens são feitos das instituições nas quais eles cresceram, que absorveram na totalidade ou em parte e que combinaram em uma personalidade individual. Mas alguns homens se transformam eles próprios em uma instituição. Holmes molda a América" (LLEWELLYN, 1935, p. 1 - tradução livre). "Men reflect institutions. Men are made of the institutions they have grown into, absorved in whole or in part, and recombined into an individual personality. But to some men it is given themselves to become an institution. Holmes molds América" (LLEWELLYN, 1935, p. 1 - original).

129 “'Se Llewellyn cunhou o termo 'Realismo' apenas alguns meses antes, Jerome Frank precisa ser creditado pelo primeiro uso do nome 'Realismo Jurídico' em um livro, Law and the Modern Mind” (HORWITZ, 1992, p. 175 - tradução livre). "If Llewellyn had coined the term 'Realism' only a few months before, Jerome Frank needs to be credited with first using the name 'Legal Realism' in his book, Law and the Modern Mind" (HORWITZ, 1992, p. 175 - original). 
em artigo denominado "Some Realism about Realism - Responding to Dean Pound" (1931).

Ressalto, com isso, que algumas das idéias realistas vinham justamente da sociological jurisprudence de Roscoe Pound. Foi Pound quem primeiro afirmou que a law in action seria diferente da law in books ${ }^{130}$. Durante os 20 anos (1916-1936) em que foi dean da Escola de Direito de Harvard, lutou para transformar o modelo educacional ortodoxo instituído por Langdell, buscando aplicar a interdisciplinaridade com a sociologia, a economia e a política (KALMAN, 2005, pp. 18-19). Assim, a fundamentação da decisão judicial não estaria circunscrita ao processo de dedução lógica decorrente dos critérios jurídicos positivos. A função judicial e a legislativa passavam a ser vistas como funções interligadas.

Muitos historiadores do direito norte-americano, como Edward White, têm dito que se for feita uma análise que contraste o contexto de desenvolvimento intelectual do início do século XX com o contexto intelectual do século XIX, é possível elaborar uma definição de Realismo que incorpore a sociological jurisprudence. Em suas fases sucessivas, o movimento realista teria sido uma crítica ao conceitualismo oitocentista. Em sua primeira fase, dominado pela Sociological Jurisprudence, criticava as consequiências políticas e sociais do conceitualismo. $\mathrm{Na}$ sua segunda fase, dominado pelos autodenominados "Realistas", criticava o aspecto filosófico do conceitualismo. O modelo inicial poderia ser resumido pelo artigo de Pound, "Mechanical Jurisprudence" (1908), enquanto o modelo tardio estaria sintetizado no artigo "A realistic Jurisprudence - The Next Step" (1930), de LLewellyn. Roscoe Pound não tinha uma premissa antiuniversalista. Seu problema não eram os princípios e as regras em si, mas as suas derivações (teoria da derivação de princípios). Já Llewellyn era contrário à teoria de Pound, pois a ausência de sentido das regras e dos princípios não estaria no seu método de derivação, mas sim se estes seriam seguidos na prática judicial (WHITE, 2003, p. 71).

No entanto, apesar de também criticar o formalismo jurídico da Classical Legal Thought, a Sociological Jurisprudence de Pound defendia que o juiz tinha o papel de

\footnotetext{
130 'O 'direito em ação' é, segundo Pound, aquele que é efetivamente aplicado pelas autoridades de aplicação, de administração, pelos corpos judiciários ou por outras autoridades oficiais, opondo-se, assim, ao 'direito no papel' (BILLIER, 2006, p. 285).
} 
elaborar constantemente o direito a partir de interpretação da lei e dos precedentes judiciais. De acordo com Pound:

\begin{abstract}
"O retrato que esbocei do juiz anglo-americano não é (...) o que traçaram nos últimos anos aqueles que se chamavam de realistas (...) o chamado realismo jurídico se relaciona mais ao realismo na arte do que ao realismo filosófico. Por igual ao realismo em arte, é culto do disforme. O realista em arte diz que o feio existe na natureza, sendo, portanto, verdadeiro. De sorte que, para ser verdadeiro, é preciso pintar o horrendo. Mas quando afirma que o feio é real pode querer dizer que existe, ninguém o nega, ou quer dizer que é significativo, o que é discutível (...). Tal acontece também com o realismo jurídico. Soubemos sempre que o processo judicial não está em absoluto de acordo, em todos os tempos e em todos os lugares e em todos os sentidos, com o ideal que dele formamos. Apesar de todos os controles com que o cercamos, não se mostra em todas as ocasiões inteiramente como o desejaríamos. Mas lutar pelo ideal - repito - muito contribui para que o realizemos. Reveste-se de importância a aproximação do ideal que dele formamos e não das deficiências que continuamente procuramos controlar e reduzir ao mínimo" (POUND, 1976, p. 98).
\end{abstract}

Essa diferença entre os realistas (pós-Llewellyn e Jerome Frank) e a sociological jurisprudence será sentida na teoria do direito brasileiro. Enquanto Roscoe Pound sobreviveu no discurso jurídico posterior à queda do Governo Vargas, os realistas propriamente ditos, como Karl Llewellyn, Frankfurter e mesmo Louis Brandeis ficaram circunscritos ao pensamento jurídico autoritário que se encerrou com o fim do Estado Novo ou com a morte daqueles que defendiam esse regime.

Nesse sentido, Roscoe Pound foi um dos grandes exemplos da transnacionalidade dos juristas durante a primeira metade do século XX. Muitos países da periferia do capitalismo passaram cada vez mais a ler Roscoe Pound e a adotar suas teorias. Um exemplo disso é que após a Segunda Guerra Mundial, Chiang Kai-shek (1887-1975) 
contratou Roscoe Pound como consultor jurídico para a construção do regime jurídico e do desenho institucional da República da China em Taiwan (KENNEDY, 2006, p.49).

O autor tinha um discurso que, apesar de antiformalista, possuía uma idéia forte de justiça. Foi exatamente essa a razão para suas divergências em relação aos autores do realismo jurídico norte-americano, como Karl Llewellyn. Esses juristas teriam, na visão de Pound, adotado "idéias absolutistas" em relação ao direito. Para Pound, a decisão judicial pode ser orientada, de tal modo que possa se torna previsível. Na obra, Minha Filosofia do Direito, Pound afirmou que:

\footnotetext{
"Se não podemos dar uma resposta que seja absolutamente demonstrável para todo mundo e totalmente convincente para o filósofo, não se conclui que não podemos ter um bom esquema viável daquilo que estamos tentando fazer, e sermos capazes de fazer uma boa aproximação prática daquilo que procuramos alcançar. Há muitas atividades práticas cujos postulados não resistirão a um exame lógico crítico se exigirmos deles uma correspondência absoluta dos fenômenos com a teoria, mas que, não obstante, servem muito bem a seus propósitos práticos (...). Se não podemos fazer uma demonstração inequívoca do fim para o qual a ordem legal está dirigida na prática, se não podemos alcançar esse fim por completo, a história da civilização mostra que podemos conseguir uma aproximação prática cada vez maior, e que é por causa dessa aproximação prática que a ordem legal e o conjunto de elementos autorizados ou guias para a decisão judicial têm sido capazes de se desenvolver e de se manter" (POUND, 2002, p. 543).
}

Essa preocupação do autor com a orientação racional da decisão judicial parece ser o principal motivo teórico para que esse jurista norte-americano fosse tão lido entre os autores brasileiros que participaram do debate sobre interpretação jurídica na primeira metade do Século XX. Ao contrário de seus adversários do realismo jurídico pós Llewellyn, Pound manteve-se como um autor influente no direito brasileiro mesmo após o fim da Era Vargas. Conforme analisarei, ao final deste trabalho, isso pode estar associado à 
relação que se estabeleceu entre o realismo jurídico norte-americano e o "absolutismo jurídico" que teria se consolidado após o debate entre Llewellyn e Pound.

Feita esta breve exposição sobre o Progressive Legal Thought norte-americano e as distinções gerais dentre os movimentos que o compuseram, passarei, no próximo capítulo, a estudar a forma como a crítica desenvolvida por esse conjunto de autores norteamericanos à estrutura do formalismo jurídico e ao conteúdo ortodoxo-liberal do direito preservados do século XIX, foi "intelectualmente deglutida" por parte da doutrina jurídica brasileira do período entre guerras. 


\section{CAPÍTULO IV - O REALISMO JURÍDICO BRASILEIRO}

"Só a antropofagia nos une. Socialmente. Economicamente. Filosoficamente.

Única lei do mundo. Expressão mascarada de todos os individualismos, de todos os coletivismos. De todas as religiões. De todos os tratados de paz.

Tupy, or not tupy, that is the question.

Contra todas as catequeses. E contra a mãe dos Gracos.

Só me interessa o que não é meu. Lei do homem. Lei do antropófago.

Estamos fatigados de todos os maridos católicos suspeitosos postos em drama,

Freud acabou com o enigma mulher e com outros sustos da psicologia impressa.

Nunca fomos catequizados. Fizemos foi Carnaval. $O$ índio vestido de Senador do Império. Figindo de Pitt. Ou figurando nas óperas de Alencar cheio de bons sentimentos portugueses. Já tínhamos o comunismo. Já tínhamos a língua surrealista. A idade de ouro.

Catiti Catiti

Imara Notiá

Notiá Imará

Ipejü $^{131}$.

Contra a realidade social, vestida e opressora, cadastrada por Freud - a realidade sem complexos, sem loucura, sem prostituições e sem penitenciárias do matriarcado de Pindorama.

Em Piratininga

Ano 374 da Deglutição do Bispo Sardinha

(Oswald de Andrade, Manifesto Antropófago)

${ }^{131}$ Lua nova/ Ó lua nova/ Assopra em fulano/ Lembranças de mim. 
No cenário brasileiro, as décadas de 1920 e 1930 caracterizaram-se como um período de intensa fermentação ideológica, refletindo a percepção de que a Primeira República havia esgotado as expectativas que envolviam sua fundação. O liberalismo foi associado às práticas oligárquicas, que pressupunham a fraude eleitoral, a escassa participação política da população e o controle do país pelos grandes estados, minando o poder da União (FAUSTO, 1991, p.14). A grande depressão mundial e, no plano interno, a revolução de 1930, provocaram nos intelectuais brasileiros da época a sensação de que era o momento de "explicar o Brasil".

Vários grupos diferentes da sociedade brasileira criticavam uma tendência enraizada do transplante de idéias estrangeiras, as "idéias fora de lugar". Essa era a tendência que dominava tanto o universo acadêmico, como o cultural, dos círculos intelectuais aos artísticos.

Nesse contexto, cem anos após a declaração brasileira de independência em relação ao domínio português, acontecia a Semana de Arte Moderna de 1922. Havia, na produção artística daquele período, duas tendências ideológicas: (i) de um lado, o Verde-amarelismo e a Escola da Anta, constituído por Paulo Menotti del Picchia (1892-1988), Plínio Salgado (1895-1975), Guilherme de Almeida (1890-1969) e Cassiano Ricardo Leite (1895-1974), cujos símbolos eram a anta e o índio tupi, defendendo um nacionalismo muitas vezes ufanista; (ii) de outro, os movimentos Pau-Brasil e Antropofagia, de artistas como Tarsila do Amaral (1886-1973), Oswald de Andrade (1890-1954), Raul Bopp (1898-1984) e Mário Raul de Moraes Andrade (1893-1945), cujo símbolo era o tamanduá, com o objetivo de produzir uma arte tipicamente brasileira, mas sem negar a arte estrangeira. Como os índios canibais devoravam seus inimigos, acreditando que assim assimilavam as suas qualidades, a Antropofagia ${ }^{132}$ propunha uma "devoração simbólica" da cultura estrangeira, aproveitando suas inovações artísticas sem perder a identidade cultural brasileira (CEREJA, 1995, p. 305).

Na década de 1930, também em uma tentativa de explicar o Brasil, Sérgio Buarque de Holanda (1902-1982) e Gilberto Freyre (1900-1987) analisaram a história da cultura

132 A Antropofagia tinha como porta-voz de suas idéias a Revista de Antropofagia, da qual participavam Antônio Alcântara Machado e Geraldo Costa (CEREJA, 1995, p. 305). 
brasileira. Era uma revisão do romantismo brasileiro e sua visão de identidade nacional. No século XIX, autores como José Martiniano de Alencar (1829-1877) e Francisco Adolfo de Varnhagen (1816-1878), haviam tentado definir a nação brasileira a partir de um foco eurocêntrico de civilização (submissão) dos índios pelos brancos. Nos anos 1930, Buarque de Holanda e Gilberto Freyre buscavam elaborar um novo olhar sobre a cultura brasileira. Buarque de Holanda tentou definir o tipo ideal brasileiro. Tratava-se do homem cordial, incapaz de separar a esfera pública da esfera privada. Já Gilberto Freyre tentou mostrar como europeus, africanos e índios dividiram seu papel na formulação da identidade brasileira.

Assim como a arte e a sociologia, o pensamento jurídico que se formou durante esse período também foi construído a partir de uma tentativa de explicar ${ }^{133}$ o Brasil a partir de uma perspectiva antropofágica. Os reflexos da crise de 1929 e do New Deal não atingiram o Brasil apenas nas esferas econômica e política. As teorias do direito norteamericano eram deglutidas pelos juristas brasileiros. Preocupados com o papel que seria exercido pelo direito no contexto da Revolução de 1930, os autores do direito brasileiro buscavam uma solução. Assim como a Columbia Law Review e a Harvard Law Review haviam se tornado um importante meio de difusão do embate entre os principais autores do pensamento jurídico norte-americano, as revistas jurídicas brasileiras, como a Revista Forense $^{134}$, tornaram-se importantes centros de debates sobre as reformas legislativas da Era Vargas.

\footnotetext{
${ }^{133}$ Ressalto que não estou a afirmar que autores tão distintos como Sérgio Buarque, Gilberto Freyre e os juristas autoritários, Alberto Torres, Oliveira Vianna e Francisco Campos, façam parte de uma mesma linha teórica ou de uma mesma tradição. Compreendo perfeitamente as diferenças de matriz teórica existentes entre Buarque e Freyre e os autoritários. Identifico, também, o fato de que, Torres e Vianna, em muitos momentos, associaram o atraso do povo e da cultura brasileira à sua mistura de raças, o que foi combatido por Freyre e Buarque. O que, no entanto, quero dizer, é que tanto os primeiros, como os últimos, fizeram parte de um mesmo contexto histórico e tinham preocupações comuns, ou seja, desenvolveram respostas diferentes para os mesmos problemas.

${ }^{134}$ Entre 1937 e 1939, inúmeros artigos jurídicos debatendo a questão social e o direito do trabalho foram publicados na Revista Forense. E embora tenhamos a visão de que os juristas brasileiros estavam isolados naquele período, a revista também publicava textos de uma série de outros países sobre os direitos trabalhistas. Só para ficar em um exemplo, em 1938 foi publicado na Forense parte do livro Evolutions et actualités (1936), de L. Josserand, sobre contratos de trabalho abusivos. No livro, Josserand analisou a jurisprudência da Corte de Cassação francesa sobre contratos de trabalho e cláusulas abusivas (JOSSERAND, 1938, p. 507).
} 
A antropofagia jurídica era crítica às idéias fora do lugar, ao liberalismo e ao individualismo, ao mesmo tempo em que apresentava um novo direito, mais próximo ao corporativismo e ao "solidarismo". Tentava inserir no ordenamento jurídico a questão social, mas para isso não seria suficiente tranformar as normas. Para um novo direito seria necessário elaborar um novo modelo de interpretação judicial, avesso ao conceitualismo e ao formalismo. Para um novo conteúdo jurídico, uma nova estrutura jurídica. O progressive legal thought norte-americano, seja na versão da sociological jurisprudence, seja na versão do realismo jurídico, parecia ser um alimento interessante para esse novo projeto. Surgia, assim, sem se transformar em uma escola de pensamento jurídico, o realismo jurídico brasileiro. 


\title{
CRÍTICA ÀS IDÉIAS FORA DO LUGAR - O PAPEL DA INTERDISCIPLINARIEDADE
}

\begin{abstract}
"Para copiar as instituições de um país e aplicá-las a outro, no todo ou em parte, é preciso, primeiro que tudo, conhecer seu todo e o seu jogo perfeita e completamente. Essas instituições, principalmente as inglesas, americanas e francesas, formam um todo sistemático e harmonioso... Cada uma de suas partes sustenta e é sustentada pelas outras e com elas se liga. É necessário muito estudo, muito critério, para separar uma parte dessas instituições e aplicá-la a outro país diverso, cuja organização, educação, hábitos, caráter e mais circunstâncias são também diversos” (URUGUAI, 2002, p. 468).
\end{abstract}

Os movimetos intelectuais brasileiros do período entre guerras tinham em comum a busca por elaborar, em suas áreas particulares, uma produção tipicamente brasileira. Havia uma aversão à mimese do estrangeiro. No entanto, esse projeto de produção autóctone foi apresentado sob diferentes matizes. De um lado, havia o nacionalismo puro (talvez ufanista e ingênuo), que rejeitava toda e qualquer contribuição estrangeira. De outro, havia o projeto antropofágico, que buscava deglutir a cultura estrangeira para elaborar uma produção propriamente brasileira. Houve, porém, dentro do ecletismo próprio da cultura jurídica brasileira, uma vertente que acabou por unir a antropofagia das idéias estrangeiras a um forte caráter nacionalista. Desse modo, enquanto no universo artístico o tamanduá tinha do outro lado da rua a anta, no universo jurídico, anta e tamanduá se misturavam. $\mathrm{O}$ resultado disso foi o surgimento do nacionalismo autoritário de autores como Alberto Torres, Oliveira Vianna e Francisco Campos. Se, de um lado, exacerbavam o nacionalismo da anta, de outro, bebiam, como o tamanduá, no mercado global de idéias jurídicas, com o objetivo de criar uma engenharia institucional propriamente brasileira ${ }^{135}$.

Os principais críticos da República Velha questionavam as tentativas de transplante de modelos estrangeiros que não se aplicariam à complexidade social brasileira. Os bacharéis da Primeira República seriam vistos como homens que tentavam instituir no

\footnotetext{
135 A partir dessa característica comum aos juristas do período, ainda mais exacerbada em Oliveira Vianna, alguns pesquisadores, como João Paulo Allain Teixeira, têm considerado que havia uma inerente contradição nessa forma de pensamento: "Ora, fica claro que o nacionalismo de Oliveira Vianna é um equívoco. Autoproclamando-se nacionalista e indo buscar em doutrinas alienígenas o embasamento para o seu discurso, cai em evidente contradição" (TEIXEIRA, 1997, pp. 104-105).
} 
Brasil modelos que não se adaptariam à estrutura periférica nacional. A ausência de uma nação e de uma sociedade ${ }^{136}$, na visão de Alberto Torres, ou de uma opinião pública, na visão de Oliveira Vianna, teriam sido elementos desconsiderados pelo pensamento liberal da República Velha durante a elaboração do projeto republicano a partir de 1889.

Uma importante característica desses autores que compuseram essa corrente crítica foi sua versatilidade intelectual. Enquanto a doutrina jurídica liberal (1870-1930) estava associada ao bacharelismo, os autores dessa corrente realista dos anos 1930 buscavam uma leitura interdisciplinar da realidade e, para tanto, aproximavam-se da sociologia, da economia e da psicologia. Essa interdisciplinariedade aproximava-os do realismo jurídico norte-americano e do sociologismo continental.

Esses autores liam e citavam a jurisprudência sociológica de Roscoe Pound (18701964, Sociological Jurisprudence) e o realismo jurídico norte-americano de Benjamin Nathan Cardozo (1870-1938, Suprema Corte), Karl Llewellyn (1893-1962), Louis Dembitz Brandeis (1856-1941, Suprema Corte) e Harlan Fiske Stone (1872-1946, Suprema Corte). Interessaram-se também por autores alemães e franceses do período, tais como Rudolf von Jhering (1818-1892), Raymond Salleilles (1855-1912), François Gény (1861-1959), León Duguit (1859-1928), Louis Josserand (1868-1941), Santi Romano (1875-1947), Maurice Hauriou (1856-1929) e Georges Gurvitch (1894-1965).

Entretanto, embora tivessem um permanente contato com a leitura de autores estrangeiros e, em especial com a grande questão global de seu tempo, a questão social, os autores brasileiros dos anos 1930 estavam preocupados em encontrar suas próprias soluções para os problemas brasileiros. Novamente, aparecia a idéia da antropofagia. A interdisciplinariedade dos realistas norte-americanos, a preocupação com a questão social de autores como Louis Brandeis e as novas formas de lidar com a interpretação da lei eram vistas por muitos como uma possiblidade de solucionar os problemas do Brasil, o que, no entanto, não poderia ocorrer em desarmonia com as características da sociedade brasileira.

\footnotetext{
136 A leitura da obra Os Donos do Poder, de Raymundo Faoro (1925-2003), parece referendar a idéia de que houve uma tentativa dos juristas brasileiros de assimilar antropofagicamente as idéias estrangeiras, quando analisou essa crítica de Alberto Torres à ausência de uma nação e de uma sociedade brasileiras: "Não se trata, agora, do nacionalismo antiluso, jacobino, dos dias de Floriano Peixoto. A perspectiva, mais larga e com base mais ampla, não se limita à defesa raivosa dos nativos contra o estrangeiro, mas sobre inspirações próprias, reconstruir, reorganizar, reformar o país, por meio do Estado" (FAORO, 2001, p. 751).
} 
Desse modo, buscavam encontrar um modo de aproximar o "país real" do "país legal". Era uma versão brasileira da separação de Roscoe Pound entre law in books e law in action. Acusavam os liberais da República Velha e seus seguidores de terem ignorado completamente o "país real". Os pais fundadores da república brasileira de 1891 teriam realizado uma série de transplantes institucionais, deixando de observar os problemas da sociedade brasileira e suas dificuldades, para assimilar modelos estrangeiros constituídos para sociedades bastante distintas. É exatamente nesse ponto que é possível medir o papel desempenhado pelas ciências não jurídicas (especialmente sociologia e psicologia) na elaboração desse pensamento jurídico dos anos 1930. A história, a sociologia e a antropologia passavam a ser intensamente utilizadas como instrumentos para se compreender as diferenças entre o "país legal” e o "país real”. Como resultado disso, as análises empíricas seriam elementos essenciais nessa tentativa de explicar o Brasil.

A crítica ao conceitualismo jurídico brasileiro de Rui Barbosa - O papel de Alberto Torres como precursor de um pensamento

No final da década de 1910, período que marcava o final da Primeira Guerra Mundial e o início do regime comunista soviético, a República Oligárquica começava a dar sinais de que o modelo político liberal e individualista entraria em crise. O Código Civil de 1916 havia sido a última grande manifestação jurídica daquele projeto. A propriedade privada e a teoria contratual da autonomia da vontade, garantidas por aquela legislação, deixavam de ser elementos absolutamente intocáveis, ao menos no discurso político e acadêmico. No centro desse debate estavam, do lado liberal, Rui Barbosa, e, do lado antiliberal, Alberto Torres.

Rui Barbosa (1849-1923) havia sido o principal nome na elaboração da Constituição de 1891. Era defensor do liberalismo e do conceitualismo jurídico que havia predominado por toda a Primeira República. Para o autor, o individualismo, a liberdade contratual e a propriedade privada eram medidas de civilização, de tal modo que a República deveria ensinar ao "povo" as "excelências do direito de propriedade" (SOUZA, 2007, p.124). De acordo com Rui Barbosa: 
"é o governo do povo senhor de si, mas limitado pelo direito, é a representação proporcional das minorias, o reconhecimento de que o direito, ainda que seja de um indivíduo só, não pode sacrificar-se aos interesses, ainda que seja do povo inteiro, é a sagração da propriedade individual, da liberdade" (BARBOSA, 1960, pp. 22-23).

Ademais, Rui Barbosa defendia que, na relação contratual, deveria haver a primazia da autonomia da vontade. Foi em defesa dessa doutrina da liberdade contratual, que Rui Barbosa argumentou no Senado, em 1898, contra a reapresentação de um projeto sobre a regulação do trabalho rural, baseando-se na intangibilidade do contrato. A regulamentação de serviços de qualquer ordem, segundo ele, implicaria a diminuição da liberdade individual, constrangendo de forma incompatível o trabalho livre. De acordo com o jurista, qualquer forma de regulamentação constituiria inclusive nova forma de escravidão, pois significaria o retorno a um regime em que não havia liberdade de celebração de contratos de trabalho, nem eram as partes consideradas iguais.

Do outro lado estava Alberto Torres, crítico do liberalismo e do conceitualismo da Primeira República. Alberto Torres ${ }^{137}$ (1865-1917) exerceu para a cultura jurídica brasileira, enquanto precursor de uma nova corrente, papel semelhante ao que Oliver Holmes havia exercido para a formação das escolas críticas norte-americanas. Embora não tenha promovido as transformações que o autor norte-americano realizou na cultura jurídica e tampouco obtido uma mísera parcela do reconhecimento que Holmes recebera, Alberto Torres foi o primeiro a apontar para as distorções dos métodos de análise das estruturas jurídicas brasileiras.

Para Alberto Torrres, as soluções políticas não poderiam ser apenas imaginadas. Pensar o desenho institucional de um país demandaria uma profunda análise de sua população e cultura. Era necessário compreender o "interesse público". Desse modo,

137 "De Alberto Torres, cuja vida fluminense e pensamento nacional mereceram um opulento livro de Barbosa Lima Sobrinho, bastaria recordar o precocínio da 'política das soluções', como expressão de uma terapêutica jurídico-social para o Brasil ou como um esquema de organização e direção; esquema que foi uma resultante direta da sua experiência à frente do governo do Estado do Rio. Ele próprio diz, por outras palavras, em A Organização Nacional, ao confiar à reflexão das elites da época seu projeto de Constituição Federal" (MADEIRA, 1993, p. 191). 
Alberto Torres criticava os transplantes das instituições européias e norte-americanas. Se não era possível transplantar a história, os costumes locais e as condições geográficas, também seria impossível fazer o mesmo com as instituições. Esse era o fundamento de Torres em suas críticas à Constituição de 1891, a seu ver, uma simples cópia das intituições inglesas e norte-americanas. Sob esse argumento, atacava o federalismo instaurado no país e defendia uma nova Constituição. Seu livro mais importante, $A$ Organização Nacional $^{138}$ (1914), é uma síntese de suas críticas às idéias fora de lugar que habitavam as instituições brasileiras e a imaginação dos juristas da República Velha.

Nessa crítica ao transplante de idéias e instituições dissonantes com a realidade social brasileira, Alberto Torres afirmou que:

\begin{abstract}
"Os países novos carecem de constituir artificialmente a nacionalidade. $\mathrm{O}$ nacionalismo, se não é uma aspiração, nem um programa, para povos formados, se de fato, exprime, em alguns, uma exacerbação mórbida do patriotismo, é de necessidade elementar para um povo jovem, que jamais chegará à idade da vida dinâmica, sem fazer-se 'nação', isto é, sem formar (...) o corpo estrutural da sociedade política" (TORRES, 1938, p. $95)$.
\end{abstract}

Assim como Holmes foi um precursor para os realistas norte-americanos, Alberto Torres foi um dos primeiros a recusar o modelo liberal da República Velha. O autor não só criticava a Constituição de 1891, como também contestava a forma como ela era interpretada. O projeto de intervenção dos $\operatorname{Estados}^{139}$ já era uma proposta de Alberto Torres, que a defendia com base na própria Constituição de 1891. Para o autor, o art. $6 .^{\circ}$ da Constituição de 1891 era:

\footnotetext{
${ }^{138}$ A obra A Organização Nacional sintetizou as principais idéias políticas e sociológicas de Alberto Torres (KUNTZ, 2000, p. 265).

139 Aliás, no plano político, o próprio governo Vargas, que surgiria anos após a morte de Torres, significou uma tentativa de "unificar" o país e construir um Brasil. Dentre essas medidas estão: a reunificação da produção legislativa processual com a Carta de 1937 e com o Código de Processo Civil de 1939; o modelo de interventores provindos de Estados diferentes para o quais foram indicados; e, talvez, o evento mais simbólico, o episódio da queima das bandeiras por Getúlio Vargas, na decretação do Estado Novo em 1937.
} 
"uma das grandes molas da política e da vida institucional do país. Sua interpretação, dada com a tendência estadoalista e critério da exegese jurídica dominante no espírito dos homens públicos, é causa de consolidação deste estado de coisas que fez dos nossos estados os vinte eixos da política do país, assim desmembrada em outras tantas tendências, opostas e em conflito. No terreno dos fatos, a prática do regime inverteu a hierarquia das instituições: a hegemonia pertence aos Estados e não à União. O pensamento do art. 6 tem sido entendido com exagerada restrição. A União tem funções permanentes e contínuas no território dos Estados e sobre seus poderes constitucionais comuns. Além dos 4 casos já previstos, o governo federal poderá intervir em negócios peculiares às províncias para tornar efetivas as garantias constitucionais à liberdade, à segurança e à prosperidade, assegurar aos cidadãos bemestar, prosperidade, educação e direito do trabalho; para harmonizar as leis dos Estados com a Constituição e leis federais; para garantir a liberdade comercial, apoiar a produção e assegurar aos consumidores a aquisição de todo quanto interessar à vida, à educação e à propriedade (...)" (LIMA, 1935, p. 261-262).

O papel de Oliveira Vianna como crítico dos clãs sociais e da ausência de opinião pública

O principal discípulo ${ }^{140}$ de Alberto Torres no exercício da crítica às "idéias fora do lugar" dos liberais da República Velha foi Oliveira Vianna. O projeto de Oliveira Vianna (1883-1951) era "corrigir" o Brasil por meio da lei e da força moral de mudança social do direito. O papel dos juristas seria observar as mudanças das sociedades contemporâneas e

140 Oliveira Vianna teve o primeiro contato com os textos de Alberto Torres a partir do artigo "Nacionalismo" por este publicado nas edições de outubro, novembro e dezembro de 1912 do jornal Vassourense. Após isso, Oliveira Vianna enviou uma resenha sobre o texto de Torres para as colunas do jornal $O$ Paiz. Esse fato teria chamado a atenção de Alberto Torres, que resolve procurar pessoalmente Oliveira Vianna, iniciando uma relação pessoal que perduraria até a morte do ex-ministro do Supremo Tribunal Federal (BRASIL, 2007, p. 115). O grupo de discípulos diretos e próximos de Alberto Torres era composto por Alcides Gentil, A. Sabóia Lima, Porfírio Netto, Antonio Torres, Carlos Pontes, Mendonça Pinto e Oliveira Vianna, que, como afirmou Vianna em prefácio de Alcides Gentil, As idéias de Alberto Torres, reuniam-se nos "serões semanais da sua casa de Copacabana, e depois, das Laranjeiras" (LIMA, 1935, p. 41). 
"a partir delas construir os parâmetros legais para a correção das desigualdades e desequilíbrios produzidos pela industrialização" (COSTA, 1993, p. 131). Desse modo, seria possível transformar, de forma ordenada e de acordo com a lei, as condições de injustiça e desigualdade, ao mesmo tempo em que se evitavam as revoluções (VIANNA, 1938, p.23).

O argumento central de Vianna em sua crítica à Constituição de 1891 era a ausência de uma opinião pública. A estrutura social do Brasil seria fragmentada, dividida por um regime de clãs. Por isso, não havia no Brasil opinião pública organizada, população consciente e participativa da vida política do país ${ }^{141}$. Segundo o autor, para os liberais, a opinião pública revelar-se-ia de dois modos: o sufrágio universal e os partidos políticos. Dessa maneira, opiniões individuais seriam aglutinadas em alguns grandes grupos, representados por partidos, tendo como resultado o regime de opinião, democrático e republicano. A opinião pública organizada, engajada e militante seria, então, o pressuposto do regime adotado pela Constituição de 1891. Desse modo, na visão de Oliveira Vianna, diante da inexistência de uma opinião pública organizada, o regime de democracia representativa não se sustentava.

141 De acordo com John French: "Ironicamente o suficiente, é o ideólogo da legislação trabalhista corporativista brasileira, Oliveira Vianna, quem declara mais claramente esta realidade objetiva na mesma página em que ele criou competentemente a tese da outorga em 1939. As iniciativas do governo após 1930, disse ele, não poderiam ter sido conquistas dos trabalhadores porque a classe trabalhadora era fraca e desunida. Os trabalhadores brasileiros no início da década de 1930, ele observou, estavam 'desagregados e desarticulados' e faltava até mesmo a unidade que deveria fluir da presença de uma ideologia dominante. Além disto, a classe trabalhadora daquela época não tinha solidariedade, regimentação e organização que poderiam ter 'imposto uma orientação a seu favor no Estado'. Tomada como uma observação empírica em um momento no tempo, a declaração de Oliveira Vianna pode, de fato, ser julgada como uma avaliação essencialmente precisa do nível real da consciência, coesão e organização da classe trabalhadora especialmente em São Paulo. Por razões ideológicas, é claro, Vianna ligará essa verdade à sua própria crença falsa na não existência da luta de classes no Brasil. Para ter sentido na história, entretanto, nós não devemos substituir avaliações moralistas ou ilusórias de força da classe trabalhadoras para julgamentos empíricos inflexíveis" (FRENCH, 1991, p. 19 - tradução livre). "Ironically enough, it is the ideologue of Brazilian corporatist labor legislation, Oliveira Vianna, who most clearly states this objective reality on the very page where he authoritatively advenced the outorga thesis in 1939. The government's initiatives after 1930, he said, could not have been worker's conquests because the working class was weak and disunited. The Brazilian workers in the early 1930s, he observed, were 'disaggregated and disarticulated' and lacked even the unity that might flow from the presence of a dominant ideology. Moreover, the working class at that time lacked the solidarity, regimentation, and organization that could have imposed an orientation in its favor upon the State'. Taken as an empirical observation at one moment in time, Oliveira Vianna's statement can indeed be judged to be an essentially accurate assessment of the actual level of working class counscioness, cohesion, and organization - especially in São Paulo. For reasons of ideology, of course, Vianna wil link this truth to his own false belief in the non-existence of class struggle in Brazil. To make sense of history, however, we must not substitute moralistic or wishful assesments of working-class strength for hard-headed empirical judgments" (FRENCH, 1991, p. 19 - original). 
Para Vianna, com a extinção do Poder Moderador, a Constituição de 1891 subordinou o Poder Executivo ao Poder Legislativo, de modo que vários atos do Executivo tinham de ser autorizados pelo Parlamento. O pressuposto era que o Parlamento representava a opinião pública (que os republicanos julgavam aqui existir) e que, portanto, ele devia ter primazia no cenário político do país. Porém, segundo Vianna, isso, além de ser uma ilusão, era extremamente "pernicioso" à vida política da nação. Partindo-se da premissa de que o Parlamento era dominado por interesses de grupos locais, qualquer mecanismo que significasse alguma forma de controle do Executivo pelo Legislativo seria equivalente à submissão do órgão representativo dos interesses da Nação (a Presidência da República) ao órgão representativo dos interesses dos clãs partidários.

Essa preocupação com o faccionismo político e a ausência de unidade em torno das questões centrais para a sociedade era comum a muitos pensadores do período. A democracia e, especialmente, os partidos políticos e a representação parlamentar eram examinados com desconfiança em diversas partes do mundo. $\mathrm{O}$ filósofo pragmatista norteamericano John Dewey demonstrou também se preocupar com esse tema, analisando com bastante pessimismo as possíveis conseqüências dos conflitos políticos para a harmômia social:

"A briga de interesses, partidos e facções é particularmente danosa porque o problema é um problema comum humano, a todos afetando os modos por que é tratado e os resultados daí advindos. A primeira necessidade é o estudo científico do tipo de sociedade cooperativa. Teoricamente é concebível que a disputa de interesses possa trazer maior clareza aos diferentes interesses envolvidos e aos modos como devem ser harmonizados por uma solução duradoura. Mas enquanto o conflito for conduzido na pressuposição, de cada lado, da posse de uma verdade já feita - pressuposição que importa em negar a necessidade de qualquer exame científico das condições, para o efeito de se determinarem as políticas que devem ser adotadas - a rivalidade dos partidos será uma fonte de divisão e confusão" (DEWEY, 1970, p. 163). 
De um modo geral, nos anos 1930, uma série de pensadores políticos, de diferentes países, difundia a idéia de que era necessário sobrepor o interesse comum aos interesses de grupos ou facções. Seja nos países que adotaram a solução autoritária, como o Brasil, seja naqueles que tentavam manter a democracia, como os Estados Unidos, o debate político era visto mais como a razão para o impasse e para a crise do que como um instrumento político para o exercício da democracia ${ }^{142}$.

No contexto brasileiro, as facções políticas eram vistas ainda com mais desconfiança pelos intelectuais da Era Vargas, pois haviam sido, em grande medida, os inimigos derrotados pelo regime. Os partidos estaduais, e, especialmente, os paulistas, legitimadores do coronelismo e da política dos governadores, durante a República Velha, eram os espantalhos do novo regime. A representação parlamentar, símbolo dos desentendimentos entre as elites durante o regime anterior, era apresentada como um elemento de distanciamento entre representantes e representados.

Aparecia, nesse contexto, os conceitos de Oliveira Vianna qualificadores da organização política em idealismo utópico e idealismo orgânico. Segundo Vianna, toda organização política deveria refletir, na sua estrutura, as particularidades e idiossincrasias do povo a que pertence. As organizações políticas que assim não o fizessem, não seriam adequadas à realidade de sua nação. Seriam organizações políticas contaminadas por um idealismo utópico, por um "conjunto de aspirações políticas em desacordo com as condições reais e orgânicas da sociedade que pretende reger e dirigir”. Já organizações políticas concebidas a partir da observação da evolução orgânica da sociedade, da observação de suas especificidades, seriam, para Vianna, organizações políticas baseadas em um idealismo positivo, um idealismo orgânico, conjunto de aspirações apoiadas em observações empíricas da realidade da nação.

A partir daí, utilizando esses dois conceitos, de idealismo utópico e de idealismo orgânico, Oliveira Vianna examinou as organizações políticas que foram projetadas nos

\footnotetext{
${ }^{142}$ John Dewey apontava para uma crise global que poderia resultar em risco para a própria democracia. Segundo Dewey: "o problema da democracia tomou uma nova forma, não havendo muita experiência disponível a respeito da relação dos fatores econômicos, como eles operam presentemente, com os fins e os métodos democráticos. Na ausência de experiência adequada, a tendência é a de armar teorias globais em oposição uma à outra; sendo, aliás, a própria colocação atual do problema humano - como individualismo versus socialismo - ao mesmo tempo, uma expressão reflexa das divisões dos fatores econômicos da sociedade presente e um exemplo desse tipo de oposição global" (DEWEY, 1970, pp. 162-163).
} 
regimes políticos brasileiros, classificando-as ora como organizações políticas utópicas, ora como organizações políticas orgânicas. Assim, para Vianna, eram utópicas tanto as organizações políticas propostas pelos liberais durante o Império (primeiro período) como a organização política republicana vigente até 1937 (segundo período). Contrariamente, a organização política desenvolvida a partir da instauração do Estado Novo (terceiro período) seria orgânica, uma vez que teria dado ao Executivo Federal a primazia sobre os demais poderes, extinguindo os partidos politicos e instituindo mecanismos de representação profissional (Conselhos, como o Conselho da Economia Nacional).

Desse modo, com uma obra extensa, Oliveira Vianna tratou de realizar uma leitura histórica estrutural, que lhe permitisse identificar o que seria a "verdadeira fisionomia do país" (FAUSTO, 2001, p. 30), desenvolvendo um estudo sobre as instituições jurídicas brasileiras que rompia com o discurso teórico dominado por autores como Rui Barbosa, Pedro Lessa (cujo modelo já havia sido contestado por Alberto Torres, 1865-1917) e Waldemar Martins Ferreira (1885-1964).

Assim, a leitura de Oliveira Vianna sobre o Brasil abria, ainda que sob uma perspectiva autoritária, caminho para a crítica à ortodoxia liberal da Primeira República. Essa ortodoxia liberal que se sustentava a partir da abstração de conceitos jurídicos garantidores da ordem privada, que por sua vez garantia a manutenção de um sistema político que havia eternizado no poder uma pequena elite aristocrática e tradicional. Nesse sentido, embora Oliveira Vianna não estivesse, de fato, preocupado com a redistribuição do poder e das riquezas, conseguia, por meio de suas críticas, atacar alguns dos sustentáculos da ordem excludente da Primeira República.

Como examinarei, na seqüência deste trabalho, essas críticas foram essenciais para o desenvolvimento de uma teoria social para o pensamento jurídico brasileiro, uma vez que romperam com as bases jurídicas que haviam legitimado a Primeira República e afatado do centro do debate a questão social. 


\section{A CULTURA JURÍDICA E A QUESTÃo SOCIAL}

Durante os anos 1920 e 1930, uma atenção especial foi dedicada à coordenação dos conflitos entre classes sociais. Em quase todos os sistemas jurídicos dos países de alguma forma inseridos no capitalismo industrial, havia a criação de novos campos jurídicos que tinham o objetivo de dialogar com a questão social. Era uma tentativa de reformar o pensamento substancialmente individualista que havia se consolidado na segunda metade do século XIX.

Naquele momento, a cultura jurídica brasileira precisava encontrar estruturas normativas aptas a suportar o desenvolvimento acelerado de um modelo de capitalismo industrial e, ao mesmo tempo, controlar o crescimento de demandas por direitos sociais. Como resultado disso, foram intensificados os debates entre a doutrina jurídica sobre a criação de campos jurídicos capazes de estruturar normativamente as relações de trabalho.

De acordo com Wanderley Guilherme dos Santos, entre 1930 e 1939, foram produzidas no Brasil "as mais argutas análises sobre o processo político nacional", elaborando-se "as principais hipóteses sobre a formação e funcionamento do sistema social" ${ }^{143}$ (SANTOS, 1978, p. 38). Além de ser uma das pautas centrais das políticas de Estado, a questão social passava a ser o principal eixo norteador do debate jurídico brasileiro.

Muitos autores sustentavam que o direito privado não era adequado para regular essas novas formas de relações. A estrutura individualista e liberal do direito privado não poderia solucionar conflitos tão relacionados com o planejamento político do Estado. Essa estrutura era avaliada como mais ineficiente à medida que se via inserida no contexto de um Estado de bem-estar social. Muitos desses pensadores do direito perguntavam-se qual

\footnotetext{
143 “Os debates se iniciam pela própria significação da revolução de 30, envolvem os militares e sua relação com as demais forças sociais, retoma-se a questão da centralização, investigam-se as origens da crise nas sociedades modernas, estuda-se o impacto das sociedades avançadas em sociedades de desenvolvimento retardado, louva-se e critica-se o papel das elites e das massas no desenvolvimento social, esmiúça-se o passado nacional, pesando-se a contribuição de cada agrupamento econômico e social, elaboram-se os mais variados prognósticos sobre a provável solução do sistema nacional. A emergência de movimentos autoritários, nacionalmente organizados, oferece novo material à especulação política sobre o papel dos partidos, das massas e das elites, enquanto, o imediato passado, com as rebeldias tenentistas e os surtos comunista e integralista, em 1935 e 1938, descobrirão a temática da violência no processo político" (SANTOS, 1978, p. 38).
} 
seriam o significado e o objetivo dessa tendência de reformas sociais que se potencializava nos anos 1930. Para Oliveira Vianna, o significado e o objetivo de tais reformas poderiam ser sintetizados como o progresso e a dignidade dos trabalhadores no interior do sistema capitalista (VIANNA, 1939a, p. 106).

Nas questões envolvendo as relações de trabalho, muitos autores brasileiros compartilhavam as críticas do realismo jurídico norte-americano contra o laissez-faire e a interpretação liberal da autonomia da vontade para os contratos que regulavam as relações de trabalho. Lembra-se aqui de que as relações de trabalho eram reguladas no Brasil por meio de contratos de locação de serviços. Desse modo, as críticas dos realistas norteamericanos contra a decisão da Suprema Corte no caso Lochner, bem como as defesas das políticas sociais do New Deal, foram recebidas e antropofogizadas pelo pensamento jurídico brasileiro. Nessa pauta, Louis Brandeis, ministro da Suprema Corte norteamericana e ex-advogado de sindicatos e associações trabalhistas, tornou-se um importante autor para alguns juristas brasileiros. Tanto Oliveira Vianna, membro do governo, como João Mangabeira, membro da oposição, buscavam nos votos de Brandeis inspiração para seus argumentos sobre a reformulação da regulação das relações de trabalho no Brasil.

Tanto a esquerda ${ }^{144}$, como a direita tinham a percepção de que seria necessário alterar o modelo liberal ${ }^{145}$ de regulação contratual. O contrato de trabalho, até então,

\footnotetext{
144 João Mangabeira, jurista e político de esquerda, em agosto de 1930, na Comissão de Justiça do Senado, em um voto divergente proferido em favor da viúva de um guarda civil, afirmou que: "O nosso Código, assim como o francês, também é o código dos patrões, o código da burguesia. Mas será possível que se continue, contra a evidência econômica, a classificar de contrato de locação, o ato jurídico entre o capital e o trabalho? Pode-se considerar objeto de contrato a força de trabalho, cujas relações com o capital, são a vexata questio, que agita o mundo e abala a sociedade nos seus fundamentos? O fato é que sob a forma atual da produção, a lei intervém, em todas as nações, cada vez mais, regulando as relações entre o capital e o trabalho, que deixam por isto de ser consensuais e se tornam legais” (BARBOSA, 1987b, pp. 26-27). Mesmo autores que mais tarde seriam mais reconhecidos por seus estudos de direito privado, como o professor catedrático de direito civil e de instituições de direito social nas Faculdades de Direito e de Ciências Econômicas da Universidade Federal da Bahia, Orlando Gomes (1909-1988), defendiam a criação do direito do trabalho como um novo campo do direito (A Democracia e o Direito Operário). Orlando Gomes citava Georges Gurvich e Gustav Radbruch para afirmar que o direito civil não seria capaz de incluir e solucionar os problemas dos trabalhadores, uma vez que não possuía instrumentos aptos a reconciliar os sindicatos de trabalhadores e as empresas. Seria necessário um direito do trabalho que reduzisse as possibilidades de negociação contratual, restringindo os limites da autonomia da vontade. Com isso, seria possível controlar o poder dos capitalistas (empresários). De acordo com o autor, "o Direito Operário restringe a liberdade de contratar. É restringindo-a que consegue debilitar o poder individual dos capitalistas, pois que à sombra dessa liberdade, eles haviam estabelecido, no mundo do trabalho, a ditadura do patronato. O contrato de trabalho convertera-se em ato de adesão. O vínculo que unia patrões e trabalhadores deixara de se formar democraticamente, para se estabelecer de modo despótico" (GOMES, 1938, p. 483).
} 
regulado como contrato de locação, tornava-se um dos principais temas dos debates jurídicos. O conceito contratual de autonomia da vontade, tido pelos juristas da Primeira República como uma garantia constitucional inviolável, passava a ser constantemente questionado. Assim, colocava-se em xeque o modelo liberal da Primeira República, apresentando-se um novo olhar jurídico sobre as relações entre capital e trabalho.

\section{Corporativismo e institucionalismo ${ }^{146}$}

Neste contexto de crise do liberalismo, o corporativismo ${ }^{147}$ apareceu como uma alternativa que toma conta do cenário político nacional com a Revolução de 1930, por meio das posições positivistas ${ }^{148}$ derrotadas na Constituinte de 1891 e que desde então

145 Wilson Martins explicou como, no início da Era Vargas, o nacionalismo de direita e de esquerda estiveram juntos no confronto com o modelo liberal da Primeira República: "Malgrado simplificações recentes que designam como burguesa a Revolução de 1930, o fato é que ela se definiu, na prática, como uma luta interna de tendências, na qual os grupos de Esquerda estiveram a um passo da vitória. Direita e esquerda, dizia Virgílio de Mello Franco (1897-1948) a Francisco de Assis Barbosa, definiram-se em nosso país após o movimento de Outubro. Nesse contexto, os que desejavam a restauração pura e simples da Constituição de 1891 estavam procurando desfazer, consciente ou inconscientemente, os efeitos do movimento revolucionário, sabido que o Partido Republicano fora essencialmente conservador (...) a reação instintiva dos meios católicos, como se sabe, foi opor-se à revolução, como se havia oposto à República quarenta anos antes: quanto a isso, a atitude de Alceu Amoroso Lima foi, ao mesmo tempo, exemplar e paradigmática. Mas vitorioso o movimento, como tinha sido vitoriosa a República, os dois nacionalismos, o de Direita e o de Esquerda, que de repente confluíram na estruturação do novo regime, procuram conformálo segundo as respectivas ideologias (...). Exageros polêmicos à parte, é inegável que a questão social entrava no vocabulário político e na realidade dos programas: tudo bem considerado, a Segunda República será uma república socialista, simples preparação para o Estado Novo (...)” (MARTINS, 1978, pp. 478-481).

146 Embora neste item não se trate da assimilação antropofágica do Progressive Legal Thought norteamericano pelos juristas brasileiros, ele será importante para a compreensão da forma como os brasileiros associaram o corporativismo europeu com o modelo norte-americano.

147 "No Brasil essa forma de representação tinha defensores à direita e à esquerda. Eram favoráveis à representação classista, entre muitos outros, Pontes de Miranda, Themistocles Cavalcanti, Oliveira Vianna, Agamenon Magalhães, João Mangabeira, Castro Nunes e Gilberto Amado” (LIMONGE, 1998, p. 122-123).

148 Durante a República Velha, algumas tendências político-ideológicas, derivadas do evolucionismo social de Hebert Spencer ou do positivismo de Augusto Comte marcaram o cenário político: (i) o republicanismo liberal; (ii) o jacobinismo; (iii) e o positivismo ortodoxo (CARVALHO 1990, pp. 23-29). Em São Paulo, desde a Convenção de Itu em 1873, já existia o partido republicano mais estruturado do país, formado especialmente por proprietários rurais beneficiados pela expansão do café e o sistema agroexportador. Antagonizavam diretamente com a monarquia centralizada, sustentando sua definição individualista de pacto social (definia o público como a soma dos interesses individuais) e o modelo americano de república (CARVALHO, 1990, p. 24; BOSI 1992, pp. 276 - 281). Entendiam que o uso da mão-de-obra escrava deveria ser assegurada até o momento em que a imigração européia a substituísse, vinculando uma eventual abolição ao pagamento de indenizações pelo Estado aos senhores. Tratava-se de uma composição ideológica que partia do evolucionismo social de Darwin, Haeckel e Spencer. Alberto Sales, irmão de Campos Sales, seria, ainda no período imperial, o principal teórico desse grupo, destacando-se pela incorporação do discurso do determinismo social de Hebert Spencer à defesa de um federalismo construído até mesmo com a 
haviam sido aprimoradas em sua aplicação prática no Rio Grande do Sul (CARVALHO, 1999, p. 126). O corporativismo vinha, assim, como portador da moralidade e da modernidade, partindo, no entanto, da premissa de que a democracia liberal seria uma via impossível para alcançar tais objetivos. A única maneira de se possibilitar uma efetiva representação dos diferentes interesses seria pela via não-parlamentar da representação corporativa.

A teoria do corporativismo é sustentada por dois pilares: (i) o corpo precede os membros; e (ii) o tudo é composto por todos, de forma holística. Uma confusão teórica comum é a de que corporativismo e fascismo são um mesmo sistema. $\mathrm{Na}$ verdade, o fascismo parte do modelo corporativista, mas o corporativismo não é necessariamente um modelo fascista. Para ser considerado fascista, um Estado tem necessariamente que adotar um modelo de Estado Total ${ }^{149}$, com um partido de massas único ${ }^{150}$. O Governo Vargas

separação de São Paulo do restante do país (SALES, 1887, pp. 88-118). Essa corrente foi vitoriosa nos enlaces políticos que dominaram a política nacional do início da República Oligárquica à Revolução de 1930. Os jacobinos, organizados a partir de setores da população urbana (formado especialmente por pequenos proprietários, profissionais liberais, jornalistas, professores e estudantes), localizavam como o principal entrave do Império a sua capacidade limitada de oferecer oportunidades de trabalho. Projetavam sobre a Monarquia brasileira os mesmos problemas do Antigo Regime francês, como o atraso, a corrupção e o privilégio. Não visualizavam na saída liberal uma solução, sendo atraídos por apelos abstratos de liberdade, igualdade e participação. Nutridos pelo discurso dos discípulos militares de Benjamin Constant (um dos principais nomes dessa linha política era Silva Jardim), os chamados radicais da Primeira República, foram marginalizados do sistema político pelas presidências liberais paulistas, a partir de 1894, com o fim do governo de Floriano Peixoto. A terceira variante eram os positivistas, que condenavam a Monarquia, uma fase por eles considerada teológico-militar, em nome do progresso. As idéias nucleares desse movimento eram a separação entre Igreja e Estado (o que atraía professores, estudantes e principalmente militares) e a ditadura republicana, com um Executivo forte e intervencionista. Dentro do próprio positivismo havia, porém, dissidências. O apostolado positivista, liderado por Miguel Lemos e Teixeira Mendes, e os ortodoxos gaúchos, liderados por Júlio de Castilhos, realizavam intensa militância comtiana. Esse programa reformista iria fundamentar o programa da Aliança Liberal que, em 1930, sob o comando de Getúlio Vargas, derrubaria o regime imposto pelos liberais na República Oligárquica.

${ }^{149}$ Hannah Arendt descreveu, em Origens do Totalitarismo, os meandros de uma nova forma de governo que sustentada na organização burocrática de massas e no emprego do terror e da ideologia constituiu um de seus principais traços: a destruição da condição humana. Expõe, assim, a chocante experiência da eliminação da própria espontaneidade ${ }^{149}$ como expressão da conduta humana e da transformação da personalidade humana em uma simples 'coisa'. A implementação do total passa, desse modo, necessariamente pelo estabelecimento de condições excepcionais, pois em "circunstâncias normais, isso nunca pode ser conseguido, porque a espontaneidade jamais pode ser inteiramente eliminada, uma vez que se relaciona não apenas com a liberdade humana, mas com a própria vida, no sentido da simples manutenção da existência" (ARENDT, 2004, p. 489).

${ }^{150}$ Embora alguns historiadores considerem que alguns dos principais auxiliares de Vargas, dentre os quais, Francisco Campos, foram defensores da construção de um Estado Totalitário. "É no livro O Estado Nacional que Francisco Campos elabora com minúcia de detalhes os fundamentos políticos e ideológicos que justificariam a criação de um Estado totalitário que deveria substituir o Estado liberal-democrático, uma 
adotou o modelo corporativista, mas não foi um regime fascista, uma vez que apesar de populista, seu governo não foi um governo de massas. Assim, o Governo Vargas foi nacionalista autoritário ${ }^{151}$, mas não foi um Estado Total.

Esse novo modelo de representação foi avaliado como uma solução para modernizar o país e controlar os conflitos sociais entre capitalistas e trabalhadores. Apesar dessa experiência do corporativismo ${ }^{152}$ em modelos políticos de direita como o fascismo italiano, o corporativismo foi defendido no Brasil tanto por autores de direita e de esquerda. Autores como Cavalcanti Pontes de Miranda (1892-1979), Themistocles Brandão Cavalcanti (1899-1980), Alberto Torres, Oliveira Vianna, Agamenon Sérgio de Godói Magalhães (1893-1952), João Mangabeira, José de Castro Nunes (1882-1959) e Gilberto Amado (1887-1969) foram defensores do corporativismo.

Alberto Torres sugeriu a criação de um novo Poder de Estado: o Poder Coordenador. Seu principal órgão seria o Conselho Nacional, responsável pela regulação da economia, das corporações e das relações de trabalho. Além disso, Alberto Torres propôs uma nova configuração para o Senado. Metade dos senadores seria eleita pelos sindicatos, associações e grupos ou categorias que representassem a sociedade brasileira. Apresentava-se, assim, a primeira visão brasileira de representação corporativa.

experiência, para o autor, em franco processo de decadência e desintegração. O pressuposto que acompanha essa justificação é o da falência da experiência liberal - democrática, o que resultaria na afirmação de que o totalitarismo seria como que um imperativo dos tempos modernos" (SCHWARTZMAN, 2000, p. 79).

${ }^{151}$ Em sua obra, Hannah Arendt buscou enfatizar as distinções terminológicas entre o autoritarismo, a tirania e o totalitarismo. Como síntese das diferenças tecnoestruturais dessas formas de governo, Arendt criou três modelos de representação: (i) uma pirâmide tradicional - para o governo autoritário (tipo cristão de governo autoritário); (ii) uma pirâmide em que "todos os níveis intervenientes entre o topo e a base fossem destruídos, de modo que o topo permanecesse suspenso, apoiado apenas pelas proverbiais baionetas, sobre uma massa de indivíduos cuidadosamente isolados, desintegrados e completamente iguais" - para o governo tirânico e (iii) uma cebola, "em cujo centro, em uma espécie de espaço vazio, localiza-se o líder; o que quer que ele faça integre ele o organismo político como em uma hierarquia autoritária, ou oprima seus súditos como um tirano -, ele o faz de dentro, e não de fora ou de cima" - para o governo totalitário (ARENDT, 2005, pp. 135-136).

${ }^{152}$ A primeira experiência corporativista brasileira teria acontecido no Rio Grande do Sul, sob os governos de Júlio de Castilhos, Borges de Medeiros e Getúlio Vargas (CARVALHO, 1999, p. 126). "A maior influência do positivismo ortodoxo no Brasil verificou-se no estado do Rio Grande do Sul. A constituição republicana gaúcha incorporou várias idéias positivistas. O fato de o chefe da revolução de 1930, Getúlio Vargas, e seu primeiro ministro do Trabalho, Lindolfo Collor, serem rio-grandenses, ajuda a explicar a ênfase que passou a ser dada à questão social. Lindolfo Collor, em sua justificação da nova orientação do governo revolucionário, mencionava explicitamente as diretrizes de Augusto Comte" (CARVALHO, 2007, pp. 111-112). 
Um dos mais importantes articuladores desse debate sobre a representação corporativa foi Oliveira Vianna. De acordo com a análise de Oliveira Vianna, a industrialização havia criado novos atores sociais - cartéis, associações, corporações e federações - que se organizavam e interagiam por meio de pautas de comportamento criados nesta interação. Essa forma de legislação viva adquiria imperatividade e coercitividade tal que passava a concorrer com a própria força legal do Estado (VIANNA, 1938, p. 23). Caberia ao direito responder a essas modificações, reconhecendo as novas fontes de normatividade social, absorvendo-as e concedendo-lhes unidade e estatuto jurídico. Para tanto, seria necessário repensar o próprio ordenamento jurídico para preservar a própria autoridade do Estado. O direito corporativo desenvolvia-se como uma alternativa capaz de incorporar essa normatividade advinda da esfera privada e dos novos atores sociais, "portadores de direitos também inteiramente novos, não mais de natureza individual, mas coletiva" (COSTA, 1993, P. 132).

Assim como Alberto Torres, Vianna também propunha a criação de conselhos técnicos, que deveriam regular a educação, a indústria e o trabalho (VIANNA, 1943, p. 206-207). O papel desses conselhos seria tanto o de regular as relações de trabalho, como o de adjudicar conflitos entre empresários e trabalhadores. Ademais, Oliveira Vianna propôs a criação de um Conselho Econômico Nacional, ligado tanto ao Poder Executivo, como ao Poder Legislativo. Tal proposta foi incoporada pela Constituição (Carta) de 1937 (artigos 57 a 63$)$.

A concepção de Oliveira Vianna de democracia estava, então, diretamente relacionada à representação corporativista por meio dos Conselhos Técnicos. Para Vianna, este é o modo mais eficaz de propiciar a participação popular nas decisões políticas, abrindo o caminho para a modernização do país (VIANNA, 1939, p. 163). Portanto, os Conselhos Técnicos expressavam, no pensamento de Oliveira Vianna, uma alternativa ao modelo falido da democracia liberal, forjado na Constituição de 1891, dentro do ideal de uma representação corporativa não-parlamentar.

A prática política do Estado Novo, sobretudo em seu início, correspondeu a essa perspectiva, tendo-se em conta o trabalho de construção do personagem Getúlio, o reforço de poderes em suas mãos, com apoio da elite militar e civil e a inexistência, na prática, de órgãos corporativos autônomos. Ressalve-se que a representação das "classes econômicas" 
existiu, mas sob a forma dos Conselhos Técnicos, alguns dos quais já criados antes do regime de 1937, como os órgãos de canalização de demandas, junto ao Executivo (FAUSTO, 2001, p.58).

Influenciado, por Mihail Manoilesco ${ }^{153}$, François Perroux e Sergio Panunzio (VIEIRA, 1981, p.31), Oliveira Vianna comparou diversas espécies de corporativismo, desenvolvendo a idéia de que o direito corporativo seria um novo conjunto de regras destinadas a codificar os direitos dos grupos e das coletividades. Segundo o autor, sua análise "documentaria para a história o primeiro choque visível entre nós" (VIANNA, 1938, p. 28) de duas concepções de direito: "uma individualista, tradicional e outra que nascia da crescente socialização do universo jurídico, cujo centro de gravitação vinha deslocando-se do indivíduo para o grupo em direção à nação como um todo" (COSTA, 1993, p. 133).

No entanto, não eram apenas os autores do nacionalismo autoritário que defendiam o modelo corporativista. João Mangabeira, em agosto de 1930, afirmara na Comissão de Justiça do Senado que:

\begin{abstract}
"As assembléias não se podem compor exclusivamente de representantes do povo, escolhidos por um eleitorado formado segundo o critério demográfico. Não, porque o Estado não se compõe somente de indivíduos, mas de indivíduos e corporações. Estas devem ter voz, nas questões que lhe interessam, e dizem, sobretudo, respeito à produção. $\mathrm{O}$ ponto delicado é ver como se representam. As assembléias políticas devem exercer, sobretudo, a função política. $\mathrm{Na}$ minha opinião, deveríamos ter apenas uma Câmara, não muito grande para não se
\end{abstract}

\footnotetext{
${ }^{153}$ No entanto, embora o próprio Vianna não tenha admitido, há algumas idiossincrasias significativas entre o seu modelo de corporativismo e o Estado Corporativo pensado por Manoilesco. Enquanto Vianna buscava um modelo de Estado centralizado, com o objetivo de reunir os poderes no Executivo federal, Manoilesco defendia que o Estado Corporativo não poderia "logicamente recusar o princípio de separação dos poderes" (MANOILESCO, 1938, p. 105). De acordo com o professor romeno, em seu livro O Século do Corporativismo, traduzido, em 1938, por Azevedo Amaral, "Corporativismo e descentralização do poder são sinônimos e a divisão dos poderes, no Estado liberal individualista representa, sem contestação, um certo carácter corporativo. É, pois, correto dizer que um Estado, pretendendo concentrar as funções legislativa, judiciária e executivo em um só órgão, seria contrário ao espírito corporativo" (MANOILESCO, 1938, pp. 105-106).
} 
enfraquecer, nem muito pequena para não se corromper. As assembléias muito numerosas dificilmente se organizam e resistem; as muito reduzidas facilmente se corrompem e cedem (...). Mas a lei exige uma técnica, para a qual uma assembléia não tem, nem pode ter o preparo especializado e indispensável. A função da Câmara deveria ser discutir e aceitar ou rejeitar as leis que as comissões técnicas fizessem. Competiria à assembléia política votar, por exemplo, pró ou contra o divórcio, porque não se trataria aí dum problema técnico jurídico, mas social, político, religioso, se o quiserem, que qualquer homem decidirá de acordo com as suas convicções, seus sentimentos ou sua religião. Mas uma lei de divórcio exige uma técnica, na qual um engenheiro, um militar ou um padre geralmente não podem ser peritos. Em resumo, uma assembléia política delibera e vota questões políticas ou sociais; mas não resolve, acertadamente, problemas de especialização ou de técnica" (BARBOSA, 1987b, pp. 29-30).

Portanto, o corporativismo era identificado como um importante instrumento para moralizar e modernizar a representação política. Em uma sociedade tão dividida e desprovida de consciência política, ganhava força, tanto na esquerda, como na direita, a idéia de que o corporativismo era o único meio possível para, ao mesmo tempo, identificar e representar o bem comum.

O próximo passo será analisar o modo como esse modelo de corporativismo esteve no centro do debate entre os juristas que buscavam legitimar os interesses de dois importantes pólos políticos do país: a burocracia estatal de Vargas e a elite empresarial paulista. De um lado, a tentativa de institucionalização da questão social, de outro, a defesa da ortoxia liberal. 
O corporativismo ${ }^{154}$, a questão social e os debates entre Oliveira Vianna e Waldemar

Ferreira

O discurso de Oliveira Vianna insere-se no debate político de forma intensa em dois momentos distintos: (i) em 1935, no debate com Waldemar Ferreira sobre o projeto de lei de organização da Justiça do Trabalho e (ii) em 1939, no debate com a Federação das Indústrias do Estado de São Paulo (FIESP) sobre o anteprojeto de Lei Orgânica da Sindicalização ${ }^{155}$. As idéias de Oliveira Vianna referentes ao embate de 1935 foram publicadas, em 1938, no livro Problemas de Direito Corporativo.

${ }^{154}$ A definição de "corporação" era polissêmica no discurso de Vianna. Muitas vezes, a palavra referia-se às
organizações do serviço público responsáveis pela administração dos conflitos coletivos de interesse, como
os tribunais do trabalho. Outras vezes, utilizava a palavra "corporação" para se referir às comissões e
conselhos técnicos norte-americanos, bem como às delegacias do trabalho marítimo, criadas no Brasil em
1934. Em outros momentos, Vianna referia-se ao Conselho Nacional do Café, ao Instituto do Açúcar e ao
Instituto do Café de São Paulo como corporações (COSTA, 1993, p. 136). Em todos os sentidos, no entanto,
o processo de corporativização "importa na constituição e na incorporação de organizações paraestatais (...)
mais ou menos autárquicas, dotadas de poderes complexos inclusive o de editar normas gerais dentro da
esfera peculiar de cada uma" (VIANNA, 1938, p. 63).

155 Na obra Problemas de Direito Sindical (1943), Oliveira Vianna retomou seu argumento baseado na mudança dos métodos de direito público e de interpretação judicial de acordo com os projetos da Sociological Jurisprudence e do Realismo Jurídico norte-americano. No entanto, dessa vez escreveu contra a oposição dos empresários paulistas, representados pela FIESP (Federação das Indústrias do Estado de São Paulo), ao projeto de lei de sindicalização apresentado pelo Ministério do Trabalho em 1939 (Decreto $1.402 / 1939)$.

O projeto, elaborado por Vianna, definia os critérios de sindicalização por meio de grupos profissionais homogêneos - ou seja, em sindicatos por categoria profissional conexa, similar ou afim, e não por empresa ou região. Esses critérios também deveriam ser estendidos às entidades de segundo grau, como é o caso das Federações, de âmbito estadual. Caso o projeto fosse aprovado, somente as confederações de caráter nacional poderiam congregar diferentes segmentos profissionais. Assim, a lei colocava em cheque a própria existência de associações como a FIESP, representante de todo o setor industrial paulista, e não apenas um segmento específico. Esse debate entre Oliveira Vianna e o empresariado paulista, representado pelo presidente da CNI (Confederação Nacional das Indústrias), o engenheiro Euvaldo Lodi, foi travado durante o ano de 1940 nas edições do Jornal do Commercio (12/05, 19/05, 26/05, 02/06, 09/06 e 16/06). A polêmica significou um profundo desgaste político e acadêmico para o consultor jurídico do Ministério do Trabalho. Em julho de 1941, a FIESP foi reconhecida como órgão consultivo do governo. Em 1942, o novo Ministro do Trabalho, Alexandre Marcondes Filho - advogado paulista e amigo íntimo de Roberto Simonsen, ou seja, ligado diretamente à elite empresarial de São Paulo - toma posse e aproxima os industriais paulistas do Estado Novo. A solução final do confronto ocorreria em 1943, por meio da Consolidação das Leis do Trabalho, que refletia o novo balanço de forças em favor dos grupos industriais em detrimento à elite burocrática do Ministério do Trabalho (BRASIL, 2007, p. 131). De acordo com Angela de Castro Gomes: "De um lado, a burguesia "ganha" a tutela do Estado sobre o movimento operário, desvinculando-se dos custos econômicos e "morais" de um confronto direto com os sindicatos, sobre cuja utilidade e eficácia pairavam poucas dúvidas (...). O controle do Estado sobre o movimento sindical reprimia seus "excessos políticos", exatamente em um momento crucial para a afirmação dos interesses da burguesia no cenário da economia nacional. Por outro lado, a burguesia consegue um tratamento diferenciado no que se refere a seu próprio 'enquadramento' sindical. Ou seja, a intervenção estatal nas associações de classe empresariais, motivo de forte reação a tal tipo de legislação, é contornada na medida em que permanece existindo, ao lado dos sindicatos patronais, outro esquema associativo, aceito e até reconhecido pelos poderes públicos. Efetivamente, a legislação 
Em sua obra Problemas de Direito Corporativo (1938), Oliveira Vianna retomava seu artigo Novos Métodos de Exegese Constitucional, publicado pela Revista Forense em 1937, para defender o anteprojeto da lei de organização da Justiça do Trabalho ${ }^{156}$ (por ele co-redigido quando era consultor jurídico do Ministério do Trabalho) das críticas que havia recebido de Waldemar Ferreira, tratadista de direito comercial e professor catedrático da Faculdade de Direito de São Paulo, no livro Princípios de Legislação Social e Direito Judiciário do Trabalho (1938).

O livro Problemas de Direito Corporativo, de Vianna, reuniu uma série de sete artigos publicados originalmente no Jornal do Commercio (GOMES, 1993, p. 48). O núcleo da divergência entre Oliveira Vianna e Waldemar Ferreira era que o projeto da lei de organização da Justiça do Trabalho atribuía competência normativa à Justiça do Trabalho (tal como a de estabelecer tabelas de salários e normas reguladoras das condições de trabalho). Tal delegação de poderes seria, na visão de Waldemar Ferreira, inconstitucional, pois violaria a separação dos poderes.

O conjunto de ensaios de Vianna não era apenas uma defesa do anteprojeto de lei, mas a fundamentação teórica de um "duplo movimento de centralização política e descentralização funcional" e a apresentação do "conceito-chave de corporations, entendidas como organizações com poderes coordenadores e reguladores que podiam ou não ter bases corporativistas" (GOMES, 1993, p. 49). Para o autor, a descentralização funcional somente ocorreria com uma delegação jurídica, compreendida como uma delegação de poderes legislativos a essas novas organizações, as corporations, que adotavam a condição de autarquias (VIANNA, 1983, p. 53). As corporations permitiam, para Vianna, a “assimilação, pelo Estado, das subestruturas privadas de 'tipo corporativo', que se constituíram extra-estatalmente pela força organizadora da própria vida econômica e social moderna" (VIANNA, 1983, p. 61). Desse modo, as corporações poderiam ser responsáveis por serviços fundamentais do Estado, como saúde e educação.

sindical não fora feita visando o controle das associações de classe patronais e não é de forma alguma surpreendente a constatação de um tratamento privilegiado aos interesses burgueses, tendo em vista o traçado de uma política social" (GOMES, 1979, p. 311).

${ }^{156}$ Projeto enviado à Câmara dos Deputados em 1935. 
Delinea-se, aqui, um novo aspecto da assimilação antropofágica de Oliveira Vianna sobre os autores do Progressive Legal Thought norte-americano. Trata-se de uma busca do autor brasileiro por compatibilizar o corporativismo de estado europeu com o modelo keynesiano implantado nos Estado Unidos. Embora naquele país, não houvesse sido adotado um modelo corporativista, essas corporations eram responsáveis por administrar parte significativa da economia e da sociedade norte-americana. As corporations não seriam assim "apenas possíveis nos regimes corporativos, mas podiam ajustar-se perfeitamente a regimes liberais e democráticos como o da Constituição de 1934 no Brasil e o do presidente Roosevelt nos Estados Unidos" (GOMES, 1993, p. 51).

As relações entre a Era Vargas e o New Deal é evidenciada pela leitura desse conjunto de ensaios de Oliveira Vianna, demonstrando mais uma vez a transnacionalidade da questão social para a cultura jurídica. Mais do que soluções políticas compartilhadas, havia um espectro de fundamentação jurídica (legitimação racional) comum. Ângela Castro Gomes, ao analisar a práxis corporativa de Oliveira Vianna, ressaltou a relação que o autor estabeleceu entre sua proposta corporativa e o New Deal norte-americano:

\footnotetext{
"Neste ponto, a exposição de Oliveira Vianna pode ser muito iluminadora do tipo de entendimento e de proposta corporativa que vinha articulando e que procurava defender naquele delicado momento da vida política nacional. De um lado, porque fica claro que o titulo do livro - Problemas de Direito Corporativo - referia-se à idéia das corporations norteamericanas do New Deal, isto é, ao processo de descentralização administrativa pelo qual os Estados modernos vinham passando independentemente de seus regimes políticos. Não se referia, portanto, à organização política do Estado sob forma corporativa, como agudamente apontou Alberto Venâncio Filho em sua introdução à segunda edição (VIANNA, 1983, p. 12). Este dado, contudo, não elimina a clara simpatia de Oliveira Vianna pelas corporations 'assimiladas' pelo Estado e organizadas de 'forma corporativa'. Aliás, este era o caso da Justiça do Trabalho instituída pelo artigo 122 da Constituição de 1934. Mas mesmo estas corporations de 'bases corporativas' que integravam a administração pública podiam existir em regimes liberais, embora fossem
} 
mais numerosas em 'regimes corporativos'. A flexibilidade e eficiência destas instituições derivam, inclusive, desta grande possibilidade de 'adaptação' mas exigiam que o jurista 'construísse' a lei” (GOMES, 1993, pp. 51-52).

Com isso, Ângela Castro Gomes mostra que Vianna pretendia defender que seu projeto não dependia de um determinado modelo de Estado autoritário, de tal modo que pudesse dissociar a delegação de poderes do Legislativo para outros órgãos de uma visão autoritária ou mesmo centralizadora e intervencionista de governo:

No processo de 'integração' as corporations poderiam colaborar com o Estado, mantendo sua autonomia e não se confundindo com o sistema institucional público, como na França e na Suíça; ou poderiam perder seu caráter privado, tornando-se 'parte integrante ou pelo menos subordinada ao Estado', como na Itália, Alemanha, Espanha, Portugal e Áustria. Tinha-se, no primeiro caso, o 'corporativismo de associação' e, no segundo, o 'corporativismo de Estado'. Em ambas as experiências ocorriam transformações nas instituições jurídico-politicas e o monopólio legislativo do Parlamento acabava sendo derrogado progressivamente pelo surgimento de novos órgãos administrativos (conselhos, comissões) e judiciais (tribunais) que elaboravam normas gerais, ao lado do Estado e mesmo dentro do Estado. A competência normativa das novas organizações decorria da própria estrutura dos problemas econômicos e sociais contemporâneos e, especificamente no campo do direito do trabalho, da natureza dos conflitos que passavam a ser coletivos. $\mathrm{O}$ fundamento dos poderes das corporations, desta forma, não derivava do regime político do país, que podia ser corporativista ou liberal. As nações anglo-saxônicas e os Estados Unidos, em especial, eram bem a evidência histórica que o autor sustentava para o Brasil" (GOMES, 1993, pp. 52$53)$. 
Conforme já exposto, a assimilação antropofágica do realismo jurídico norteamericano pelo pensamento jurídico brasileiro teve como eixo central a questão social. Essa assimilação foi feita tanto por autores de direita, dentre os quais se destacou Oliveira Vianna, como por autores de esquerda, dentre os quais se destacou João Mangabeira. Apesar dessa diferente matriz ideológica, as duas correntes tiveram como pontos comuns a repulsa ao individualismo liberal e a busca por uma organização política que privilegiasse o associativismo e a questão social. Esses pontos comuns foram também comuns a uma importante tendência da cultura jurídica norte-americana que tinha como principal liderança Louis Brandeis. Tratava-se do individualismo grupalista (rugged individualism).

Em 1934, João Mangabeira, relator geral do anteprojeto governamental apresentado à Assembléia Nacional Constituinte em 1933, escreveu o livro Em Torno da Constituição. Nessa obra, Mangabeira apresenta a relação entre a Suprema Corte norte-americana e a questão social, mostrando que estava bastante conectado com o debate norte-americano que lhe era contemporâneo. De acordo com o autor:

"seria interessante examinar as decisões da Suprema Corte diante da questão social; e, sobretudo, o variar de seus arestos, sob a pressão do ambiente aquecido, pela indignação popular. No caso Tyson v. Branton, dizia em 1926, o Justice Stone, chefiando a minoria, numa decição five to four, em que se averbava de inconstitucional uma lei de Nova York: 'Existe um conservantismo de espírito que põe em xeque cada inovação legislativa e a considera contrária à Constituição e perigosa, salvo quando ela se torna familiar; nossos anais estão cheios de casos onde, espécie a espécie, o exercício da regulamentação foi repelido e depois admitido'. É ver a fixação das horas de trabalho, declarada inconstitucional, em 1905, no caso Lochner v. New York e, em 1917, proclamada legal, em Sunting v. Oregon. É comparar as decisões contrárias sobre salário mínimo, em Stetler v. O'Hara e Children's Hospital v. Adkins. É confrontar, sobre operários sindicados, os julgamentos em Aldair v. United States, em 1908, e Prudential Insurence Co. V. Check e Chicago R.I. v. Perry, em 1922. É colocar face a face a jurisprudência firmada em 1921, por seis 
contra 3, no caso Duplex v. Deering e o aresto unânime de 1923, no caso Pennsilvania Railroad v. Railroad Labor Board. É ler, em quase todos esses julgados, os votos de Holmes, Brandeis, Clarke e Harlan. É por Taft diante dele mesmo, em Truax v. Corigan, em princípios de 21, e nos Coronodo Cases, em fins de 22, e no final do Pennsilvania Railroad, em começo de 23. E nos três é relator. É que vários Estados introduziram nas suas Constituições o recall dos juízes. Agitara-se a campanha pelo recall das decisões. Roosevelt, Bryan, Borah, Lê Follete não cessavam de bradar contra a atitude da Suprema Corte. Nos centros operários era enorme a agitação. A American Bar Association formara uma comissão dirigida por Brown para combater o recall. A American Academy of Political and Social Science abria um inquérito a tal respeito, no qual dois grandes juristas - Gilberto e Brown sustentaram as duas opiniões opostas - a favor e contra o recall. Por ele manifestara-se Draper - decano da Faculdade de Direito da Pennsilvania. A American Federation of Labor, dirigida, neste particular, por um jurista da ordem de Ralston, não cessava os seus ataques contra as decisões desumanas, comentando-as numa brochura distribuída pela Nação inteira. Foi ao rugir dessas ventanias que a Suprema Corte virou de proa, buscando lentamente as águas tranqüilas. Mas, ainda assim, de 15 anos retardaram as Cortes americanas as leis de acidente de trabalho, tendo sido alguns Estados, como Nova York, obrigados a reformar suas constituições, a fim de poderem ter essa legislação benemérita, geralmente adotada. Por fim, a Suprema Corte deu o golpe de morte na longa contenda, considerando constitucional as modificações introduzidas na Workmen's Compensation Laws de New York. O mesmo ocorreu com as leis contrárias ao truck system" (MANGABEIRA, 1934, pp. 123-124).

Nesse trecho, Mangabeira parece aderir à idéia vencedora na Suprema Corte norteamericana de que não seria possível enxergar a questão trabalhista e corporativa sob uma perspectiva formalista, que desconsiderava as forças sociais e políticas.

Em 8 de dezembro de 1944, João Mangabeira proferia em discurso aos formandos da Faculdade de Direito da Bahia (Oração aos Bacharelandos da Faculdade de Direito da 
Bahia), no qual evidenciava a desigualdade entre as partes do contrato laboral, com fundamento em voto de Brandeis:

\begin{abstract}
“o que não constitui 'império econômico' num grande e rico pais, pode assumir esta feição numa nação menor e mais pobre. E quando as empresas de tal sistema ultrapassam, na sua expansão, as raias do seu território nacional e vão exercer sua atividade em solo de outra nação, o imperialismo capitalístico se apresenta, em toda a sua evidência, no estado aparentemente soberano, mas de fato semicolonial. Mas o poder público não deve, sob nenhuma forma, ser transferido a uma entidade privada, que o exerça para enriquecimento privado e sob o objetivo exclusivo do lucro. A verdadeira Democracia impõe que o poder público só deva ser exercido em benefício geral da coletividade e jamais em favor de um grupo de privilegiados. Era o que proclamava, na Corte Suprema dos Estados Unidos, Brandeis, quando asseverava: 'A principal objeção contra as grandes empresas é que elas tornam possível, senão inevitável, a autocracia, industrial'. E a autocracia subiu de muito com o advento do capital financeiro, que é, na magistral definição de Hilferding, a fusão do capital industrial com o bancário (...). Há mais de 40 anos, no caso Lochner versus New York, Holmes, ante a Corte Suprema espantada e Wall Street estarrecida, sustentou num voto vencido imortal, a doutrina, àquela época singular e hoje corrente, pela qual sentenciava: - 'A liberdade de contratar implica a igualdade de condições na discussão do preço"” (BARBOSA, 1987c, pp. 31-32).
\end{abstract}

Outro autor cujas idéias também demonstram grande influência dos realistas, quando da abordagem das relações de trabalho, sob o ponto de vista do corporativismo, foi o já tantas vezes citado Oliveira Vianna. Em um livro, publicado postumamente, muito pouco conhecido dos juristas da atualidade, Problemas de Organização e Problemas de Direção (1952), Oliveira Vianna define o debate global sobre a questão social como "individualismo grupalista", identificando no ministro da Suprema Corte Louis Dembitz 
Brandeis um de seus principais defensores (Brandeis e seu Individualismo Grupalista ${ }^{157}$ ). De acordo com Oliveira Vianna:

"Na Corte Suprema Americana, ele (Brandeis) foi (...) um dos que mais vivamente reagiram contra a mecanização da aplicação da lei - contra aquilo que Morris Cohen, outro grande mestre, chama ironicamente 'a teoria fonográfica da função judicial', caricaturizando ironicamente a afirmação de Montesquieu - de que os juízes "não são senão a boca que pronuncia a palavra da Lei, seres inanimados que não lhe podem modificar nem a força, nem o rigor"” (VIANNA, 1952, p. 148) (...). “O princípio do laissez faire, característico do velho liberalismo, havia criado, segundo Brandeis, nos Estados Unidos, um sistema social e econômico onde não havia lugar para o povo-massa, para o common people, para o man in street, isto é, para a pequena propriedade, para a pequena indústria, para o pequeno comércio. Lá onde surgisse uma pequena empresa industrial ou comercial, para logo a grande empresa capitalista, o poderoso trust, disto ou daquilo, lançava-se sobre ela, a perseguia, a destruía, a matava, abrigado este trust justamente à sombra da exegese clássica da Constituição, dominante na Suprema Corte, toda ela impregnada das idéias individualistas do século XVIII (...). Ora, para Brandeis, nada mais contrário ao rugged individualism do americano, e ao seu fundo sentimento democrático. Daí a sua atitude combativa, rompendo contra os critérios tradicionais da interpretação da lei e reagindo contra a mecanização da função judiciária, donde haviam

157 "Homem do seu tempo, Brandeis também pensava assim: para preservar a pessoa do indivíduo e, especialmente, a pessoa do trabalhador e os seus direitos inalienáveis, ele sentiu que era preciso tomar como lawer (sic) ou como justice - uma posição diametralmente oposta à em que se havia colocado o pensamento político no século XVIII. Daí a sua atitude na Suprema Corte, pondo-se corajosamente ao lado do sindicato de classe (trade-union) e não do sindicato de empresa (company-union), e da convenção coletiva de trabalho como norma reguladora da categoria - e não apenas da empresa. Estas duas instituições de Direito Social eram então, uma e outra, como ainda hoje, mal vistas pelos patrões americanos, isto é, por toda poderosa oligarquia ali constituída e que - como se sabe - dos seus escritórios da Wall Street, move, através de molas secretas, todo o mecanismo do governo e da administração americana. Na opinião de Brandeis, o sindicato é o meio mais eficaz e seguro que o trabalhador americano tem para não sucumbir diante da onipotência - até há pouco bem incontrastável - de um patronato senhor de fábricas e capitais gigantescos e, invocando, para justificar o seu arbítrio, o 'direito divino da empresa'. Dentro do seu sindicato de classe, amparado nele e na sua força, o trabalhador poderá se assegurar - usando o admirável expediente das convenções coletivas (de empresa ou de categoria) (VIANNA, 1952, pp. 162-163). 
resultado o predomínio das grandes corporations (sociedades anônimas), o capitalismo implacável e insaciável de Wall Street e o arbítrio, senão a onipotência, dos patrões na determinação das condições do trabalho. Brandeis bateu-se por um intervencionismo do Estado, com a latitude revolucionária e socializadora que lhe deu Roosevelt, ao lado de quem se colocou resolutamente. Não era, por certo, um liberal - à maneira clássica, dentro de um espírito anti-grupalista - à russa, à fascista ou à nazista. Não obstante todo o seu amplo intervencionismo, não deixou ele, um minuto sequer, de ser um americano típico - um old american, nutrido do individualismo grupalista e do espírito dos Pirigrim Fathers e dos velhos "pioneiros"” (VIANNA, 1952, pp. 152-153).

Desse modo, Oliveira Vianna buscava no individualismo grupalista de Louis Brandeis uma resposta para as comparações de seu modelo corporativista com o corporativismo nazi-fascista. No entanto, isso não era apenas uma tentativa de legitimação de sua obra a partir de autores democráticos, como disseram muitos de seus críticos (cf. CARVALHO, 1987). Mesmo que essa tentativa de legitimação tenha ocorrido, não é possível, apenas por isso, desconsiderar a relação que se estabeleceu na obra de Vianna com as teorias de Brandeis. Essa relação se fez tanto a partir da introdução do conteúdo da questão social, como também a partir das propostas de mudança estrutural de Brandeis.

A obra de Brandeis estava intimamente ligada às mudanças na forma como a Suprema Corte decidia os casos envolvendo a questão social. Tais transformações passavam necessariamente pela crítica ao conceitualismo jurídico da Corte do caso Lochner. Desse modo, ao mesmo tempo em que buscava transformar o conteúdo decisório da Suprema Corte, Brandeis também tinha que contestar sua forma de decidir. Foi essa dupla crítica ao liberalismo e ao conceitualismo que foi a base para assimilação de Brandeis por Vianna. Foi trambém essa dúplice crítica que fundamentou o pensamento de Oliveira Vianna, tornando-se uma pedra basilar de sua teoria.

Assim, embora tivessem posições ideológicas quase que opostas, Oliveira Vianna, um autor de direita, e João Mangabeira, um autor de centro-esquerda, defendiam a regulação da questão social e do direito do trabalho e tinham métodos de trabalho 
semelhantes. Mais do que isso, ambos bebiam no individualismo grupalista de Louis Brandeis, o grande nome da mudança na forma como a questão social foi tratada nos Estados Unidos.

O fundador do Partido Comunista Brasileiro, João Mangabeira, teria em sua tendência centro-esquerda e na crítica à ortodoxia-liberal, certa semelhança com Louis Brandeis. Outro aspecto, no entanto, aproximava mais o autoritário Vianna de Brandeis do que Mangabeira de Brandeis. Trata-se da relação intrínseca que esses autores estabeleceram entre conteúdo e estrutura, ou, posso dizer, entre a questão social e o método jurídico. Ambos desenvolveram seus argumentos jurídicos a partir de elementos externos ao direito, como estudos sociológicos e históricos. Além disso, tanto Vianna como Brandeis, buscavam examinar os problemas de seus países a partir da leitura comparada das diversas soluções dadas pelos mais diversos países, mesmo que isso significasse estudar modelos de Estado que fossem ideologicamente divergentes dos seus. Nesse sentido, o pensamento jurídico defendido por Brandeis e Vianna foi absolutamente transnacional. 


\section{NOVOS MÉTODOS DE DIREITO PÚBLICO (ANTICONCEITUALISMO) - A QUESTÃO SOCIAL E A INTERPRETAÇÃO JURÍDICA - CONTEÚDO E ESTRUTURA}

A transnacionalidade da questão social também estava associada a outro debate, o da redefinição dos métodos jurídicos e a superação do modelo liberal conceitualista. As idéias anticonceitualistas estavam relacionadas com as fortes críticas contra o formalismo e ao modelo mecânico de decisão judicial. Para os anti-conceitualistas, explicar o significado da lei envolveria elementos externos ao direito (law in action era diferente do law in books). Desse modo, o raciocínio jurídico não deveria estar limitado ao processo lógicodedutivo. De acordo com essa visão, a adjudicação e a produção legislativa precisariam se tornar processos mais conexos. Seria necessário transformar o papel do juiz, que nem deveria ser um dedutivista, nem um legislador (neither an abuser of deduction neither a rational law maker). Como resultado disso, a interpretação judicial foi um elemento crucial na reformulação da pauta de debates da cultura jurídica. No entanto, não é possível analisar esse debate metodológico desassociado do debate sobre a questão social. Tanto nos Estados Unidos como no Brasil, pelo menos em um primeiro momento, foram debates conjugados. Foi assim que essa questão foi apresentada por Oliveira Vianna e, de certo modo, foi assim que ela continuou a ser analisada por Alípio Silveira, ao examinar o papel do fator social na hermenêutica jurídica.

Percebe-se que, nesse período, ainda não havia uma especialização (ou feudalização) do estudo do direito brasileiro. Havia uma questão que predominava no discurso jurídico: a questão social. Essa questão era examinada por civilistas, comercialistas e constitucionalistas. Talvez porque ainda não se houvesse consolidado uma disciplina de direito do trabalho, as relações de trabalho eram analisadas sob seus aspectos constitucionais ou sob sua regulação pelas regras de direito privado, em especial pelo Código Civil. 
A questão social e o "método jurídico" ${ }^{158}$ : direito público ou direito privado?

Nos Estados Unidos, a dicotomia entre direito público e direito privado estava associada ao Classical Legal Thought do final do século XIX. O Progressive Legal Thought, de Holmes a Llewellyn, havia sido extremamente crítico a essa divisão rígida do direito. No Brasil, tratou-se também da dicotomia entre direito público e direito privado, porém com um enfoque um pouco diferente.

Durante os anos 1930, alguns juristas brasileiros tentavam estabelecer novos contornos diferenciadores entre métodos do direito público e métodos de direito privado. Mesmo porque, se as relações trabalhistas fossem consideradas relações de direito privado, nas quais prevalecesse a relação contratual, entendiam alguns que deveriam ser examinadas pelo "método de direito privado". Por outro lado, se fossem consideradas relações de direito público, deveriam ser examinadas pelos "métodos de direito público".

Oliveira Vianna foi um desses juristas que examinou a dicotomia entre direito público e direito privado. O autor apresentou suas idéias sobre essa questão, em 1937, em Novos Métodos de Exegese constitucional. O jurista fluminense defendia uma ruptura com

158 José Reinaldo de Lima Lopes diferencia método e técnica de pesquisa. Para o autor: "O método pode ser definido como o procedimento teórico, pelo qual se estabelecem os conceitos e suas relações entre si, ou, dito de outra forma, pelo qual se constrói um objeto teórico. Há uma relação de correspondência entre o método e o objeto (...). Cada campo do saber, ou ciência se quisermos facilitar a linguagem, determina-se por um objeto teórico e pelo método pelo qual esse objeto é construído. Os objetos teóricos não se confundem com os objetos empíricos e, por isso mesmo, muitas vezes os iniciantes não se dão conta de que estão de fato usando algum objeto teórico. Objetos teóricos são como 'tipos', 'conceitos': são artefatos intelectuais, não são coisas, nem eventos, nem relações naturais. Duas pessoas se apaixonam e fazem 'promessas' de viver juntas, de serem felizes juntas, até morrer. Acontece com muita gente, com a maioria talvez. Esta paixão, este amor, esta atração, esta inclinação para o outro pode ser objeto de análise de muitas disciplinas. Cada uma delas constrói, para compreendê-la, um 'objeto teórico'. O direito vai transformar este fato natural em uma 'relação', que poderá ser tratada como relação de fato ou relação de direito, e, sendo de direito pode transformar-se quiçá em casamento, ou união estável, ou parceria civil, ou sociedade de fato. O que às vezes engana os mais incautos é que o objeto teórico parece confundir-se com o objeto natural e isto chega a tal ponto que já não distinguimos bem um do outro: assim, esta relação entre duas pessoas será sempre chamada de 'casamento', assim como o fato natural da 'atração dos corpos' será às vezes chamado de simples manifestação da 'lei da gravidade'. Mas a natureza, para ser objeto da ciência da física, não 'obedece' a uma lei, pois 'obedecer' é comportamento de sujeitos, e a natureza não tem subjetividade na ciência. Fernando Pessoa tem um belo verso que expressa poeticamente esta idéia: "Eu compreendo a natureza por fora, / porque a natureza não tem dentro/ senão, não era a natureza” (...). O método (procedimento teórico) pressupõe a causalidade (um conceito, uma relação, não uma coisa); isola um possível fenômeno que possa ser a causa de outro (hipótese) e, sendo isto verdade, deduz as conseqüências possíveis (previsíveis). Se algum evento desviar-se da hipótese, ela é invalidada (falseada, na linguagem de Karl Popper). Deve-se começar tudo de novo. O método científico exclui explicações pela intenção, pela liberdade ou pela finalidade: as coisas se explicam pelas suas causas. A ciência moderna começou a nascer quando se abandonaram as explicações da natureza pela sua suposta finalidade” (LOPES, 2005, pp. 9-11). 
o modelo formalista de interpretação constitucional brasileiro e a adoção de um método de interpretação judicial semelhante ao processo construtivo norte-americano. Segundo ele, os juristas brasileiros de seu tempo tratavam todos os textos constitucionais como se estivessem diante de um texto de Direito Comercial, Civil ou Processual. Essa atitude derivava de questões que envolviam desde a atividade estritamente forense da maior parte dos juristas brasileiros até a inexistência de verdadeiros publicistas em nosso país. Esses juristas eram, em sua maioria, civilistas, comercialistas, processualistas ou grandes advogados, não incorporando o espírito de "verdadeiros publicistas" ${ }^{159}$ (VIANNA, 1938, p.28). As técnicas de interpretação ${ }^{160}$ que aplicavam às normas de Direito Constitucional eram as mesmas que utilizavam para o direito privado $^{161}$.

\footnotetext{
${ }^{159}$ De acordo com o próprio Oliveira Vianna, sua obra teria influenciado autores como Castro Nunes (18821959), Levi Carneiro (1882-1971), Orlando Gomes (1909-1988) e Nestor Duarte (1902-1970), o primeiro, ministro do Supremo Tribunal Federal e, os tres últimos, renomados advogados e professores de direito: "Note-se que estas modernas tendências do direito público e constitucional, essa inclinação para a objetividade, pelo menos, esta preocupação do dado concreto - do fato (econômico, social, culturológico, demográfico ou etnográfico) - na interpretação dos textos constitucionais já se deixa entrever na obra de dois modernos constitucionalistas brasileiros: Castro Nunes e Levi Carneiro, o primeiro ministro hoje do Supremo Tribunal e o segundo grande advogado militante do nosso Fórum. Deste v. - Federalismo e Judiciarismo (1930), Pela Nova Constituição (1937), Problemas Municipais (1931), O Direito Internacional e a Democracia (1945), O Livro de um Advogado (1943). Daquele v. A Jornada Revisionista (1924), O Estado Federado e sua Organização Municipal (1920), Teoria e Prática do Poder Judiciário (1943), O espírito público fora dos partidos (Publicações do DIP $\mathrm{n}^{\circ}$ 9). Fluminenses ambos e dotados, por isso mesmo, do senso político - quero dizer, desta preocupação de construção e direção política, que é o traço peculiar aos publicistas e homens de pensamento da velha Província - são dois espíritos abertos, arejados pelas leituras e pelo contato com o estrangeiro, recebendo de primeira mão essas lufadas de realismo e de objetividade, que estão renovando a atmosfera intelectual do mundo. Nesta mesma direção, embora um tanto presos ainda como publicistas - aos velhos estereótipos juricivilistas, caminham também dois novos juristas do Norte: Orlando Gomes e Nestor Duarte. Deste v. O Direito-noção e norma, Rio, 1933; A ordem privada na organização política nacional, São Paulo, 1939. Daquele v. - A crise do Direito, Rio, 1945" (VIANNA, 1974, p. 50).
}

160 "Ninguém ignora que a constituição não é igual às leis ordinárias. Isso não é novidade alguma. Na Suprema Corte Norte-Americana isso é lugar-comum há quase dois séculos. Até mesmo Forsthoff, um ácido crítico de métodos de interpretação exclusivamente constitucional, não deixava de reconhecer que uma constituição 'contém elementos que a diferenciam dos outros tipos de leis'. No entanto, quando se analisam os princípios e métodos que são propostos, percebe-se que muitos não passam dos métodos civilistas rebatizados, ou de meras reações a situações históricas passadas ou, por fim, de máximas sem maiores significados além daqueles que o simples bom senso do intérprete já requeria” (SILVA, 2005, p. 140).

${ }^{161}$ Ou seja, "ao terem que descobrir o sentido íntimo dos preceitos de uma Constituição, aplicam os mesmos métodos que usam habitualmente para descobrir o sentido de uma regra de Direito Civil ou Comercial" (VIANNA, 1938, p.28). 
No primeiro volume de Instituições Políticas Brasileiras ${ }^{162}$, publicado pela Editora José Olympio $^{163}$, Oliveira Vianna parte das idéias de Huntington Cairns para explicar sua proposta metodológica diferenciada para o estudo do direito, afirmando que:

\begin{abstract}
"a nova metodologia coloca o problema do estudo de direito em geral e, em particular, o estudo do direito público e constitucional e o da ciência política. É somente este método comparativo dos comportamentos sociais que dará à ciência do direito a possibilidade de entrar na categoria das ciências sociais - pensa Cairns. Porque, para ele, as ciências sociais podem ser definidas como um grupo de ciências, cujo objetivo é 'o estudo do comportamento humano, tal como se manifesta em ações na sociedade'. Daí concluir-se que, se a ciência do direito pretende elevar-se à condição de uma ciência social, ela não pode deixar de ter - como o seu objetivo fundamental - o estudo do comportamento humano neste domínio (...). Em vez de um problema de hemenêutica constitucional, torna-se, assim, o estudo do nosso direito público e constitucional um problema de culturologia aplicada" (VIANNA, 1974, pp. 38-39).
\end{abstract}

Assim, embora, de modo semelhante ao Classical Legal Thought norte-americano, os juristas brasileiros e, em especial, Oliveira Vianna, realçassem as dicotomias existentes entre o direito público e o direito privado, não o faziam com o fim de neutralizar politicamente o direito, como o haviam feito os norte-americanos oitocentistas. Ao contrário, buscavam com isso politizar a hermenêutica jurídica, em um sentido similar ao objetivo do Progressive Legal Thought norte-americano. No caso brasileiro, esses juristas dos anos 1930 combatiam a neutralização do direito público que, segundo eles, havia sido praticada pelos privatistas da Primeira República. Diante disso, ampliava-se a crítica àquilo que Oliveira Vianna chamava de marginalismo político e de idealismo utópico.

\footnotetext{
162 "Instituições políticas brasileiras é um fruto temporão do grande movimento de idéias antiliberais que varreu o Ocidente nas décadas de 1920 e 1930 e, no Brasil, se condensou na crítica às instituições e práticas políticas da Primeira República (1889-1930)"(ALMEIDA, 2004, p. 295).

${ }^{163}$ Após 1937, a Livraria José Olympio tornar-se-ia a editora do Estado Novo e seus "corifeus" (Castro Faria, 1993, p. 284).
} 


\section{A hermenêutica jurídica de Oliveira Vianna e a crítica ao marginalismo político}

No segundo volume de Instituições Políticas Brasileiras, Oliveira Vianna analisou o debate entre Rui Barbosa ${ }^{164}$ (1840-1923), o espantalho de seu discurso, e Alberto Torres. A partir da análise desse diálogo, e, em especial, pelo debate construído por Oliveira Vianna, é possível identificar a sua crítica ao marginalismo político dos liberais por meio do instrumental do realismo jurídico norte-americano.

O autor considerava que suas idéias eram similares ao pensamento jurídico norteamericano progressista (American Progressive Legal Thought), representado pelo realismo jurídico e pela jurisprudência sociológica (American legal realism e sociological jurisprudence ${ }^{165}$ ). Para Vianna, o behaviorismo, o funcionalismo, o anticonceitualismo e o método jurídico empírico presentes no pensamento jurídico norte-americano dos anos 1930 era compatível com o modelo de interpretação judicial que deveria ser utilizado no Brasil. E, mais importante do que isso, a crítica daquela geração de juristas norte-americanos em relação ao mecanicismo judicial das gerações anteriores fundamentaria a crítica de Vianna ao mecanicismo dos juristas brasileiros. Em função disso, Oliveira Vianna buscava incorporar os métodos de interpretação constitucional norte-americanos, em especial, o que chamava de "método construtivo" de interpretação constitucional da "new jurisprudence $^{, 166}$ de Holmes, Cardozo, Brandeis, Stone e Llewellyn. De acordo com Vianna:

\footnotetext{
${ }^{164}$ Rui Barbosa era um admirador do direito anglo-americano.

165 Apresenta-se aqui a new school/sociological jurisprudence e o realismo jurídico/funcionalismo como correntes diferentes inseridas em um mesmo movimento de crítica ao modelo conceitualista. "Para a Escola de Jurisprudência Sociológica, as premissas de silogismo legal devem ser preenchidas, não por um raciocínio prioritário nem por preceitos autoritários indicados arbitrariamente, mas por conceitos forjados na chama da vida em sociedade (ARONSON, 1938, p. 12)". "For the School of Sociological Jurisprudence the premises of legal syllogism should be filled in, not by a priori reasoning, nor by authoritarian precepts arbitrarily indicated, but by concepts forged at the fire of life in society" (ARONSON, 1938, p. 12).

166 Percebe-se que, na maioria das vezes, Oliveira Vianna não distinguia a sociological jurisprudence do realismo jurídico norte-americano, incluindo todos em uma mesma corrente: "os renovadores da escola sociológica americana - com a new jurisprudence school, ao lado de Holmes, Pound, Cardozo, Brandeis, Freund, Franfurter e tantos outros que abandonaram - na interpretação do direito e na aplicação dos textos legais - o velho texto dedutivista" (VIANNA, 1974, pp. 50-51).
} 
"Para os construtores americanos, a Constituição é um sistema permanente, uma estrutura eterna, dentro da qual a sociedade evolui, cresce, desenvolve-se, diferenciando-se e progredindo. Todo trabalho 'construtivo' do intérprete está em procurar ajustar o sistema da Constituição e a estrutura político-administrativa a esta sociedade em evolução, de maneira que essa encontre nesse sistema ou nessa estrutura um instrumento (...) facilitador desta evolução" (VIANNA, 1938, p.13). “Por meio da 'construção', A Constituição americana não se imobiliza, não se fixa num sistema de regras ou princípios invariáveis e rígidos, a que as realidades sociais, bem ou mal, têm que se submeter; ao contrário, torna-se flexível, dinâmica, viva, aderindo à sociedade e evoluindo com ela" (VIANNA, 1938, p. 13).

O realismo jurídico norte-americano era funcionalista/instrumentalista e, portanto, finalístico. Desse modo, compreendia o direito como meio para satisfazer as políticas governamentais de alocação dos recursos disponíveis (BILLIER, 2005, pp. 252-253). Assim, não parece ter sido apenas coincidência que (i) as preocupações com a interpretação constitucional de Oliveira Vianna tivessem sido fruto de sua defesa por formas diferentes de organização do trabalho e que (ii) o Progressive Legal Thought norteamericano tivesse sido desencadeado a partir da oposição que alguns juristas daquele país fizeram à Lochner decision, que também abordava questões relativas às relações de trabalho. Eram simetrias que ligavam o processo de crise do hemisfério norte à industrialização forçada do hemisfério sul. Havia algo de comum entre o New Deal e o Varguismo. Tratava-se de um período em que se percebia a necessidade de repensar os fundamentos da sociedade do século XX e de suas instituições (ainda vinculados ao século XIX).

A síntese do debate sobre hermenêutica jurídica em torno da estrutura da questão social e “reprivatização" do debate sobre interpretação judicial

A síntese de boa parte do debate sobre interpretação judicial nas décadas de 1920 e 1930 e que, portanto, incluía a relação entre a interpretação judicial e a questão social, foi 
feita por Eduardo Espínola e seu filho, Eduardo Espínola Filho. No Tratado de Direito Civil Brasileiro, composto por dez extensos volumes, os autores analisaram muitos dos modelos de interpretação judicial existentes no mundo e examinaram o uso que vinha sendo feito desses modelos pelos juristas brasileiros. No volume 4 dessa obra, O Método Positivo na Interpretação e na Integração das Normas Jurídicas, os autores estudaram o debate norte-americano entre o Progressive Legal Thought e o Classical Legal Thought, a consolidação da Sociological Jurisprudence e do Realismo Jurídico. Analisaram também a crise entre Roosevelt e a Suprema Corte durante a implementção no New Deal.

Além desse estudo sobre o debate norte-americano, os Espínola examinaram os reflexos dessas transformações na cultura jurídica norte-americana sobre a cultura jurídica brasileira, em especial no discurso de Oliveira Vianna sobre a interpretação das leis do trabalho. No capítulo A interpretação das leis do trabalho e as opiniões de Castro Nunes, Oliveira Vianna e Waldemar Ferreira. As observações de Carvalho Mourão, os Espínola contrapõem os argumentos desses quatro autores na definição do papel institucional da Justiça do Trabalho ${ }^{167}$ e na existência ou não de uma diferença na forma como a legislação social deveria ser interpretada pelos juristas brasileiros. O interessante é que são estudados autores com papéis sociais bastante distintos: Oliveira Vianna era membro da burocracia do Governo Vargas; Waldemar Ferreira era advogado e havia sido deputado federal pelo Partido Democrático, opositor do regime; e Castro Nunes (1882-1959) e João Martins de Carvalho Mourão (1872-1951) haviam sido ministros do Supremo Tribunal Federal de gerações distintas.

Como era uma tendência dos autores da época, especialmente nos "Tratados", os Espínola, muitas vezes, apenas citavam longos trechos dos textos dos autores que pretendiam estudar. Desse modo, de Castro Nunes, analisaram um trecho do texto

\footnotetext{
${ }^{167}$ Em Waldemar Ferreira, analisaram trechos do livro Princípios de Legislação Social e Direito Judiciário do Trabalho, publicado em 1938 (FERREIRA, 1938, p. 121), destacando o fato de que, para Ferreira, não seria possível descartar a equiidade e o contrato de trabalho, de tal modo que, embora a Justiça do Trabalho devesse ser mais ágil e simples que as demais, não poderia tratar as parte de forma diferente. Os autores concluíram o capítulo com um trecho de um voto do ministro do Supremo Tribunal Federal (Suprema Corte) Carvalho de Mourão, publicado em 1936 pela Revista Arquivo Judiciário. Nesse trecho, o ministro descaracterizava o papel judicial da Justiça do Trabalho no interior da Constituição de 1934, qualificando-a de tribunal arbitral, o que significaria que suas decisões "não consubstanciam uma sentença" (MOURÃO, 1936, p. 346).
} 
publicado na Revista Arquivo Judiciário, em 1937, cujo título era Da justiça do trabalho no mecanismo jurisdicional do regime. No texto, o autor defendia que na Justiça do Trabalho deveria ser mitigada a "igualdade processual dos litigantes" em prol da "paz social" e de evitar-se a "luta de classes" (NUNES, 1937, p. 8). Em relação a Oliveira Vianna, foram estudados trechos ds texto "Justiça do Trabalho", publicado, em 1937, no livro Direito Aplicado (VIANNA, 1937, pp. 332-333) e Problemas de Direito Corporativo, de 1938 (VIANNA, 1938, p. 21), destacando-se a concordância de Vianna com Castro Nunes sobre o papel da Justiça do Trabalho e a defesa de que a interpretação judicial que envolvesse os setores da economia e do trabalho deveria ser feita pelos “critérios do método sociológico e dos standards legais, à maneira de Brandeis e Holmes na Suprema Corte Americana" (VIANNA, 1937, p. 333). Além da influência dos ministros da Suprema Corte norte-americana, os Espínola destacaram as influências de Eugène Ehrlich, François Gény e Carl Schmitt (1888-1985), na obra de Vianna. Por fim, os Espínola criticam algumas das conclusões de Oliveira Vianna:

\footnotetext{
"O notável jurista peca, entretanto, quando, encarecendo a necessidade de fazer-se a interpretação ampla, livre, adiantada, em assuntos de direito público, e, particularmente, nas questões trabalhistas, acha que a pura exegese, acanhada e tradicionalista, manietando o direito e subordinando as realidades da vida às regras impassíveis e retrógradas dos códigos, é adequada em matéria de direito privado, é própria do direito privado" (ESPÍNOLA, 1940, pp. 52-53).
}

Nessa crítica à Oliveira Vianna fica evidente a proposta dos Espínola de recuperar para o campo do direito privado o debate sobre hermenêutica jurídica. De certa forma, tinham ao seu lado o fato que de o Código Civil de 1916 possuia mais tempo de vigência que qualquer uma das Constituições promulgadas ou outorgada no período republicano (1891, 1934 e 1937). O Código Civil também tinha mais aceitação perante a comunidade jurídica, uma vez que, por ser apresentado como neutro e apolítico, não trazia consigo qualquer risco de contágio ideológico, nem com Vargas, nem com seu opositores, exceto 
por sua defesa intrínseca da ortoxia liberal da Primeira República, o que, de modo algum, preocupava a tradicional cultura jurídica brasileira.

O golpe fatal para essa "reprivatização" do debate sobre a interpretação jurídica seria dado pela Lei de Interpretação ao Código Civil de 1942. A LICC não só incorporou o discurso sobre a hermenêutica jurídica como também pretendeu internalizar no direito civil a principal pauta jurídica daqueles tempos: a questão social. A forma como essa mudança da legislação brasileira refletiu sobre a cultura jurídica e sobre o modo como os juristas iriam enfrentar a questão social será o tema abordado na seqüência deste trabalho. Antes disso, no entanto, farei uma breve análise sobre as continuidades e rupturas que estiveram presentes nos discursos do principais autores brasileiros que escreveram sobre a interpretação jurídica até a Era Vargas.

Os novos modelos de interpretação judicial e os "fins sociais" da lei

No início do século XX, o Brasil se inseria definitivamente no debate sobre a interpretação judicial. Desde o final do século XIX, o Estado Legislador e a subordinação da interpretação autêntica da lei aos parlamentos eram questionados ${ }^{168}$. Além disso, a interpretação literal e mecânica da lei era substituída por novos modelos de interpretação.

\footnotetext{
${ }^{168}$ Durante o período imperial, o tema provocou intensos debates no Conselho de Estado. Uma parcela dos conselheiros defendia a atribuição da interpretação por forma geral e regulamentar ao Supremo Tribunal. Outros, como Pimenta Bueno, entendiam que a interpretação autêntica era função indelegável do Poder Legislativo. Havia ainda, aqueles que entendessem que a interpretação autêntica deveria ser mantida provisoriamente sob a competência do Conselho de Estado (Nabuco de Araújo). Essa percepção de delegação provisória da interpretação autêntica ao Conselho de Estado, condicionada a uma posterior transmissão desse poder ao Judiciário pode ser verificada a partir da análise da circular de 7 de fevereiro de 1856 emitida por Nabuco, enquanto Ministro da Justiça. Estabelecia-se um sistema provisório em que o governo exerceria o direito de interpretação até dele que fosse encarregado o Supremo Tribunal de Justiça. Defendia essa posição com base nas transformações na divisão funcional do modelo francês: "Em França, não obstante as dúvidas de legitimidade e competência, o Conselho de Estado exerceu esse direito até que a lei do $1^{\circ}$ de setembro de 1837 o conferiu ao Tribunal de Cassação. Se essa interpretação, que o governo tem exercido por via de autoridade, é, posto que dependente da hermenêutica, a mesma interpretação autêntica que ao Poder Legislativo compete, a consequiência é que o mal que todos deploramos, essas dúvidas de todos os dias e sobre tudo não tem remédio por ser praticamente impossível que o Poder Legislativo as decida, e tão inconstitucional é que a decisão compita ao Poder Executivo como a qualquer outro poder, que não o Legislativo. Seja como for, o governo tem exercido esse direito de interpretação por meio de decretos, instruções, regulamentos, até por avisos. O que tenho de dizer, porém, não significa que entendo que seja mantido esse direito. Na reforma judiciária eu o atribuía o Supremo Tribunal de Justiça, como centro da jurisprudência e maior categoria na hierarquia judiciária, porque reconheço os inconvenientes e o perigo de que esse direito que ao Poder Executivo compete, se estenda às leis judiciárias, as quais dizem respeito à
} 
Durante o Brasil Império, os poucos trabalhos significativos sobre hermenêutica jurídica foram os de Francisco de Paula Baptista, Compêndio de Theoria e Prática (1855) e Hermenêutica Jurídica (1860), e de Joaquim Ignácio Ramalho, o Barão de Ramalho, Postilas de Prática (1865). O estudo de Paula Baptista foi uma tentativa de sistematizar em alguns parágrafos regras de interpretação para o direito brasileiro. Tratava-se de conjunto de preceitos definidores da postura do juiz perante o texto legal. De acordo com o autor, "Interpretação é a exposição do verdadeiro sentido de uma lei obscura por defeitos de sua redação, ou duvidosa com relação aos fatos ocorrentes, ou silenciosa. Por conseguinte, não tem lugar sempre que a lei, em relação aos fatos sujeitos ao seu domínio, é clara e precisa" (BAPTISTA, 1860, nota 1 , do $\S 3 .^{\circ}$ ). Desse modo, Baptista limitava o papel da interpretação ao preenchimento das lacunas do texto legal, na busca por encontrar o sentido pretendido pelo legislador. Já o texto de Ramalho consubstanciou-se em um conjunto de comentários aos artigos de Paula Baptista. Divido em cinco "Lições", o estudo do Barão de Ramalho preocupou-se, especialmente, com o que se convencionou como método de interpretação histórica. Para o autor "não deve o intérprete interpretar as palavras da lei conforme o sentido que elas têm na época da interpretação, mas sim de conformidade com a significação que elas tinham na época em que escreveu o legislador, porquanto só nesse sentido poderá ele ter empregado as palavras" (RAMALHO, 1865, p. 114-115).

Durante a Primeira República, o principal autor dedicado ao estudo dos modelos de interpretação ${ }^{169}$ havia sido Carlos Maximiliano Pereira dos $\operatorname{Santos}^{170}$ (1873-1960). Era um

propriedade, liberdade, honra e vida do cidadão, sendo que, desde que se trata de qualquer desses objetos sagrados, começa a competência do Poder Judiciário. Enquanto, porém, não encarregais esse direito ao Supremo Tribunal de Justiça, o governo não pode deixar de exercê-lo, porque, como já vos disse, alguma autoridade o deve exercer, porque não é possível sacrificar a lei à controvérsia, ao sofisma e à anarquia. Pressupondo esse direito, julgou o governo imperial conveniente fazer cessar o seu abuso, o qual aliás não dissimulo poderia importar gravíssimos conflitos, provocando contra ele uma reação funesta e prejudicial à divisão e harmonia dos poderes políticos. Assim que pela circular que se segue providenciou o governo sobre esta matéria, impondo-se as regras que deveria seguir no exercício daquele direito, em quanto lhe competir e não for atribuído, como aliás convém que seja, ao Supremo Tribunal” (sic NABUCO, 1997, pp. 259-260).

169 O autor diferenciava hermenêutica de interpretação. Segundo ele, interpretação seria a aplicação da hermenêutica, que descobre e fixa os princípios que regem a interpretação. Desse modo, "A Hermenêutica é a teoria científica da arte de interpretar" (MAXIMILIANO, 2006, p. 1).

170 Carlos Maximiliano Pereira dos Santos (1873-1960) foi Deputado Federal, Deputado Constituinte em 1933/34, Ministro da Justiça e Negócios Interiores, Consultor Jurídico do Ministério da Justiça, ConsultorGeral da República, Procurador-Geral da República e Ministro do Supremo Tribunal Federal (1936-1941). 
dos poucos juristas que já vinha escrevendo sobre o tema nos anos que tinham se seguido ao Código Civil de 1916, ou seja, bem antes da tomada do poder por Vargas. Em 1924, lançou a obra Hermenêutica e Aplicação do Direito. No prefácio à primeira edição de sua obra, Maximiliano afirma ter analisado o tema em função "dos erros de interpretação

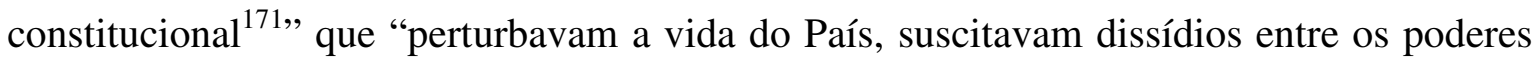
públicos e comprometiam o prestígio das instituições" (MAXIMILIANO, 2006, p. IX). No entanto, nesses primeiros textos, Maximiliano não estabelecia qualquer conexão entre a interpretação judicial e a questão social ou qualquer "fim social da lei".

O primeiro brasileiro a estabelecer relações entre a interpretação e os chamados “fins sociais da lei” foi Alberto Torres. Alberto Torres (descrito por Oliveira Vianna em Instituições Políticas Brasileiras como um autor realista) escreveu em A Organização Nacional que juízes e legisladores precisariam comprender a interpretação judicial de acordo com o fim prático da sociedade. Para o autor, o elemento prático da interpretação judicial precisaria estar relacionado ao bem comum. Como ministro do Supremo Tribunal Federal (1900-1909), Alberto Torres dizia que a lei era uma expressão da vida social e, sob essa fundamentação, não baseava seus votos, como fazia a maioria dos outros ministros, na jurisprudência e doutrina de outros países. Desse modo, introduzia a idéia de que para se aplicar a lei, deveria se considerar as peculiaridades da sociedade brasileira, "as suas necessidades, a marcha da sua evolução social, os problemas especiais da sua política, o conjunto das suas idéias morais, a sua situação econômica, as peculiaridades criadas pela sua história, pelo meio físico, e pelos vários fatores da individualização dos povos” (LIMA, 1935, p. 33).

Com isso, introduzia-se no debate brasileiro sobre a interpretação judicial o elemento "fim social” da lei. Em 1914, Alberto Torres afirmava que:

\footnotetext{
171 Ao analisar a interpretação constitucional, Maximiliano utiliza-se da obra Commentaries on the Constitution of the United States de Joseph Story. De acordo com Maximiliano: "Forte é a presunção da constitucionalidade de um ato ou de uma interpretação, quando datam de grande número de anos, sobretudo se foram contemporâneos da época em que a lei fundamental foi votada. 'Minime sunt mutanda, quoe interpretationem certam semper habuerunt'. Todavia o princípio não é absoluto. O estatuto ordinário, embora contemporâneo do Código supremo, não lhe pode revogar o texto, destruir o sentido óbvio, estreitar os limites verdadeiros, nem alargar as fronteiras naturais. Recorda Story várias interpretações e plausíveis conjecturas triunfantes nos primeiros anos da prática constitucional e totalmente abandonados depois. Observou-se no Brasil o mesmo fato: 'exempli gratia' - por quantos estágios passou entre nós, até a vitória da doutrina sã e definitiva, a inteligência do dispositivo que assegura as imunidades parlamentares" (MAXIMILIANO, 2006, p. 250).
} 
"Na interpretação da Constituição e das leis, devem os juristas, legisladores e todos aqueles a quem competir a sua aplicação, ter em vista os seguintes princípios, de preferência a outras regras jurídicas de interpretação: I. A Constituição é uma lei política, de fins práticos, fundada em objetos sociais concretos, e destinada principalmente a manter ligados, harmônica e organicamente, os interesses gerais e permanentes do país; II. A base de sua interpretação é o fim prático e social que seu conjunto e seus princípios se destinam a realizar; III. Nem o sentido literal do texto, nem a fonte, origem, escola ou tradição doutrinária, a que estiver ligado, servirá de argumento a qualquer interpretação contrária a seu destino prático e seu fim social; IV. Por elemento histórico da interpretação deve entender-se, não somente, nem principalmente, os debates, pareceres, discursos legislativos e mais atos preparatórios da elaboração da lei, mas, sobretudo, a razão de legislar e os interesses, relações e fatos inspiradores dos princípios legislativos, e seus fins permanentes e gerais; V. Sendo objeto da Constituição e das leis promover os fins da sociedade e da vida individual, seus princípios devem ser entendidos no sentido mais favorável a tais fins; ao desenvolvimento e progresso da sociedade e ao interesse e prosperidade dos indivíduos; VI. O elemento prático da interpretação deve ser entendido com relação ao bem-estar geral e permanente da sociedade e do indivíduo, ao desenvolvimento e sucessão progressiva dos fatos e fenômenos sociais e jurídicos, e jamais aos acidentes, fatos isolados e interesses parciais e momentâneos" (TORRES, 1914, pp. 418-419).

No entanto, apesar de Alberto Torres já abordar o tema em 1914, os "fins sociais" da lei somente entrariam definitivamente na pauta jurídica nacional no final da década de 1930, quando se iniciavam as discussões em torno da elaboração de uma nova lei de introdução ao Código Civil. 


\section{O debate em torno da Lei de Introdução ao Código Civil e os "fins sociais" da lei}

Essa relação entre a questão social e o anticonceitualismo na interpretação judicial durante os anos 1930 foi visível ainda no debate em torno da Lei de Introdução ao Código Civil de 1942. Inserida em um contexto que visava desconstruir o projeto liberal do Código Civil de 1916, a LICC reproduzia na literalidade do texto legislativo o discurso doutrinário em torno da reformulação do método de interpretação judicial.

Ao determinar que o juiz levasse em consideração os "fins sociais" a que se destinava a norma jurídica, o art. 5. ${ }^{\circ}$, do Decreto n. 4.657, de 4 de setembro de 1942 (Lei de Introdução ao Código Civil), instituía uma mudança na interpretação judicial e, como conseqüência, expunha os juristas a um debate necessário sobre a questão social. É isso o que percebem autores como Alípio Silveira e Eduardo Espínola. Por mais legalista que fosse o corpo de juristas, teriam de considerar a questão social como elemento central da interpretação judicial.

Já às vésperas da promulgação da Lei de Introdução ao Código Civil de 1942, houve uma grande preocupação de parte da doutrina jurídica brasileira sobre a relação entre interpretação judicial e a questão social. Em 1940, Cesarino Júnior ${ }^{172}$ (1906-1992) publicava seu livro Direito Social Brasileiro. Nesse texto, o autor fez algumas críticas ao uso do realismo jurídico norte-americano e da jurisprudência sociológica. No entanto, Cesarino Júnior não diferenciou os dois movimentos e demonstrou desconhecer os debates traçados entre Pound e Llewellyn sobre a interpretação judicial.

172 Bacharel em Ciências e Letras (Colégio Culto a Ciência, Campinas, 1923), bacharel em Direito (Faculdade de Direito de São Paulo - USP, 1928), doutor em Direito (Faculdade de Direito da Universidade de São Paulo - USP, 1938), médico (Escola Paulista de Medicina, 1952), doutor em Economia (Faculdade de Ciências Econômicas da USP, 1960), médico Sanitarista (Faculdade de Higiene e Saúde Publica da USP, 1965), professor Catedrático do Ginásio do Estado (Campinas, 1929, São Paulo, 1934), professor Catedrático da Faculdade de Direito da USP (1938 - Primeiro professor concursado de 'Legislação social' no país), professor Visitante da Universidade de Wisconsin, (EUA, 1953), professor Honorário da Universidade Central da Venezuela (1955), professor Catedrático da Faculdade de Economia da USP (1960), onde já era professor desde 1948, professor Titular da Faculdade de Medicina da Pontifícia Universidade Católica de São Paulo (Sorocaba, 1962), ex-Membro da Comissão de Peritos da Organização Internacional do Trabalho (Genebra, 1976), professor Emérito da Faculdade de Direito da USP (1978), membro Honorário da Sociedade de Medicina do Trabalho (Strasbourg, 1954), presidente da Sociedade de Medicina Social e do Trabalho (São Paulo, 1955), membro da Academia Nacional de Letras Jurídicas - Co-fundador, Presidente Honorário e Presidente Efetivo da Société Internationale de Droit du Travail et de la Sécurité Sociale (Genebra, 1958 e 1982), co-Fundador e Primeiro Presidente da Associação Nacional de Medicina do Trabalho ANAMT (São Paulo, 1968), membro Honorário da ANAMT (São Paulo, 1977). Presidente de Honra da Academia Nacional de Direito do Trabalho (1978) (www.institutocesarinojunior.org.br). 
"Esta escola sociológica de Pound e Llewellyn, esta interpretação realista das leis, entretanto, levada às suas últimas consequências, seria perigosa, às vezes mesmo anárquica, pois se 'a preocupação do intérprete não é o texto em si e nas suas relações com os outros textos', corre-se o risco de um completo desprezo pela lei escrita, desaparecendo assim a segurança que ela visa assegurar e, dando-se ao juiz um arbítrio exagerado, com o permitir-lhe 'construir' o texto de acordo com a sua fantasia. Pensamos, portanto, que deve haver muita moderação no emprego deste método, devendo-se reservá-lo quase exclusivamente para os casos da repressão da fraude à lei” (CESARINO, 1940, pp. 104-105).

No mesmo período, Eduardo Espínola, outro ministro do Supremo nomeado por Vargas, tornar-se-ia o principal nome brasileiro dos estudos sobre a interpretação judicial. Em 1939, foi publicado o seu Tratado de Direito Civil Brasileiro, e o terceiro livro do tratado, Da Interpretação e da Aplicação do Direito Objetivo, era dedicado exclusivamente ao tema da interpretação.

Um outro autor significativo para o período, mas completamente esquecido pela maioria dos juristas da atualidade, foi Alípio Silveira. Seus dois principais livros, O Fator Político-social na Interpretação das Leis e A Hermenêutica Jurídica segundo a atual Lei de Introdução ao Código Civil, foram publicados em 1946, apenas um ano após o fim do Estado Novo varguista. Além de criticar o regime autoritário, Silveira estava preocupado com a influência dos elementos políticos e sociais sobre a interpretação judicial. Partindo da premissa de que o juiz não estaria impedido de interpretar amplamente o texto da lei, Silveira argumentava que a aplicação mecância da lei teria sido substituída por um processo. Nesse sentido, o juiz poderia preencher o significado da lei de acordo com o bem comum (SILVEIRA, 1946, pp. 358-359). Essa explicação estaria fundamentada pelo artigo 5. ' da Lei de Introdução ao Código Civil (1942): "Na aplicação da lei, o juiz atenderá aos fins sociais a que ela se dirige e às exigências do bem comum". 
De acordo com o autor, a inserção do art. $5 .^{\circ}$ da LICC no ordenamento jurídico brasileiro significava:

“1 $1^{\circ}$ ) Repulsa à interpretação literal, dedutivista e à aplicação mecânica da lei; $2^{\circ}$ ) Repulsa ao sistema interpretativo da intenção ou vontade do legislador, de cunho subjetivista, substituído por aquele da intenção ou fim da lei, de caráter objetivista; $3^{\circ}$ ) Repulsa ao in claris cessat interpretatio, já que toda e qualquer aplicação de lei deverá conformar-se aos seus fins sociais e às exigências do bem comum, sem embargo de sua aparente ou superficial clareza; $4^{\circ}$ ) Predomínio do caráter valorativo, político-social, da interpretação e conseqüente alargamento desse conceito, como desenvolvimento vivo, quase uma segunda criação da regra já estabelecida pelo legislador; $5^{\circ}$ ) Atenuação do liberalismo individualista abstrato e do absolutismo dos direitos individuais" (SILVEIRA, 1946, p. 67).

Para fundamentar as relações entre o regime político-social e a interpretação das leis, Alípio Silveira buscava definir as finalidades para o Estado e para a sociedade das diversas áreas do direito. Considerava que "a finalidade do direito do trabalho, e a sua natureza, estão inteiramente ligada à filosofia político-social imperante na Constituição" (SILVEIRA, 1946, p. 138). Para o autor, a filosofia política brasileira que dominava a Constituição seria a mesma nos Estados Unidos: “o individualismo temperado pelo bem comum" (SILVEIRA, 1946, p. 138). Para confirmar essa semelhança, Silveira citou $A$ Natureza do Processo e a Evolução do Direito, de Benjamin Cardozo.

No entanto, apesar de sua preocupação em estabelecer uma relação entre o regime político e a interpretação judicial, Alípio Silveira analisava os limites do poder de interpretação da lei pelo juiz. De acordo com o autor:

“A interpretação é um instrumento para a aplicação e execução da lei. Nesta qualidade, não pode deixar de respeitar a finalidade da lei. A 
interpretação deve mover-se dentro do círculo traçado pela suprema finalidade da lei interpretada. E esta suprema finalidade da lei tem íntimas relações com a estrutura político-social, com os fins do Estado. E assim podemos concluir que estes últimos influem sobre a interpretação, por meio do conteúdo ou finalidade da lei” (SILVEIRA, 1946, p. 128).

Ao tratar sobre o tema da hipossuficiência do trabalhador em relação ao empregador, Alípio Silveira defendeu que a interpretação da lei não deveria favorecer necessariamente ao empregado. De acordo com Silveira:

"ao harmonizarem os interesses da empresa e dos empregados, na aplicação da lei, os juízes devem sempre fazer prevalecer o interesse coletivo ou bem comum, sobre qualquer interesse de classe ou particular. Se, depois de utilizados os recursos comuns da hermenêutica, ainda persistem dúvidas, deve o juiz proceder a uma delicada pesquisa de valoração entre os interesses de ambas as partes. Os interesses da empresa, às vezes, poderão prevalecer, já que o Direito do Trabalho os tem na devida conta (...), desde que não sejam contrários ao bem comum. O mesmo se diga dos interesses do trabalhador. Em conclusão: o brocardo 'na dúvida, pró-trabalhador' é falso, como princípio geral do direito. $\mathrm{Na}$ realidade, entre os casos de dúvida que significam praticamente algumas dezenas ou centenas de cruzeiros para o trabalhador de uma próspera empresa, e aqueles outros que significam a própria vida da empresa, se escalona uma vasta série de casos intermédios (...)" (SILVEIRA, 1946, pp. 140-141).

Assim, Alípio demonstra seu aspecto mais conservador. Eram os ares de um novo tempo que se iniciava com a queda de Vargas. A questão social havia sido definitivamente incluída na pauta jurídica, mas teria que ceder espaço novamente para a ordem liberal. Nesse sentido, Silveira assume que os "fins sociais da lei" do art. $5^{\circ}$ da LICC teriam servido para reformar o liberalismo, mas sob uma perspectiva que se afastava do Welfare 
State da década de 1930 e se aproximava de um modelo neo-liberal ${ }^{173}$ (SILVEIRA, 1946, p. 68).

Um autor de um período um pouco posterior, Oscar Accioly Tenório (1904-1979), publicou o livro Lei de Introdução ao Código Civil (1955), no qual realçou o caráter anticonceitual e empírico da lei:

\begin{abstract}
"O mérito da doutrina aceita pela Lei de Introdução, a contrabalançar o inconveniente de uma concepção incerta, é de considerar a lei como realidade viva, variável com as condições de cada época e de cada meio, libertando o juiz da servidão da letra da norma. Na falta de uma conceituação legal do fim social da lei, cabe ao intérprete, em cada caso, ver se a norma a aplicar atende ao fim social. Anticonceitual o critério, por força do empirismo que o domina" (TENÓRIO, p. 164).
\end{abstract}

Também de um período posterior ao de Alípio Silveira, Wilson de Souza Campos Batalha publicou a obra Lei de Introdução ao Código Civil (1957), o único livro que aborda a Exposição de Motivos da LICC e fala sobre a Comissão responsável pela elaboração da lei ${ }^{174}$. Ao analisar a expressão fins sociais no art. $5^{\circ}$., o autor discutiu os possíveis sentidos da lei e reduziu seu conteúdo, afirmado que:

\footnotetext{
${ }^{173}$ De acordo com o autor: "o critério dos fins sociais e das exigências do bem comum veio corresponder à renovação do liberalismo - ao neo-liberalismo. Por outro lado, a aplicação desses critérios dos fins sociais e das exigências do bem comum não permitirá ao intérprete postergar precisas disposições de lei. O princípio da legalidade, salvaguarda da segurança e da certeza do direito, mantém toda a sua força dentro dos quadros do neo-liberalismo" (SILVEIRA, 1946, p. 68).

${ }^{174}$ Os textos contemporâneos sobre a Lei de Introdução ao Código Civil de 1942, como o de Maria Helena Diniz, Caramuru Afonso Francisco e Norberto de Almeida Carride são quase sempre recortes sobre a aplicação da lei pelos tribunais. No que se refere ao tema deste trabalho, nenhum livro contemporâneo trata da história da elaboração da lei. Dentre os autores pesquisados, Wilson de Sousa Batalha, em 1956, foi o único que abordou o tema, analisando a Comissão constituída pelo Ministério da Justiça para reformar o Código Civil, mas que acabou apenas reformando a Lei de Introdução.
} 
"A referência aos fins sociais da lei pode ter, apenas, dois sentidos: a) consagrar uma filosofia individualista-social, ou uma filosofia supraindividualista, contrastando com a filosofia individualista-liberal; b) consagrar o critério teleológico ou finalista na interpretação da lei, colocando em plano subalterno os demais critérios de Hermenêutica. Não se nos afigura tenha sido a primeira a intenção do art. ora comentado. $\mathrm{O}$ que distingue o individualismo-social do individualismo-liberal é a circunstância de que, naquele, o Direito encara o indivíduo concreto e socializado, preso a círculos sociais determinados, ao passo que o individualismo liberal encara o indivíduo abstratamente, como simples sujeito de direito, consagrando uma liberdade e uma igualdade meramente formais. Parece-nos óbvio que a transposição do individualismo-liberal para o individualismo-social só pode ser obra da lei e não da simples tarefa interpretativa, porque ao juiz não é dado estabelecer diferenciações quanto à aplicação da regra de direito, tendo em vista a posição social ou econômica dos que lhe são sujeitos, desde que a lei não os tenha diferenciado (...). Seja como for, embora ganhe grandes desenvolvimentos à teoria do abuso do direito em nosso país, não paira dúvida que o legislador brasileiro não pretendeu estabelecer flagrante insegurança nas relações jurídicas, tendo em vista considerações de ordem social, sempre suscetíveis de serem deturpadas através de pontos de vista individualíssimos e puramente subjetivos" (BATALHA, 1957, pp. 545-547).

Desse modo, apesar de ter sido pensada e inserida no ordenamento jurídico brasileiro durante a Era Vargas, a Lei de Introdução ao Código Civil (1942) foi interpretada e re-interpretada por autores que escreveram predominantemente após o fim do Estado Novo. Aliás, talvez seja a razão de essa lei ter sobrevivido sob o viés liberal do direito privado brasileiro que retomaria seu espaço após a queda de Vargas. A presença da questão social no art. 5. ${ }^{\circ}$ da LICC é evidente, mas seu papel foi bastante minimizado pelos juristas e, em especial, pelos privatistas. 


\section{A BUROCRACIA ESTATAL E O ESTADO DE DIREITO (RULE OF LAW ${ }^{175}$ )}

Tenho repetidamente afirmado, nesta dissertação, que no período entre guerras, o conteúdo questão social trazia consigo o debate sobre a reformulação da estrutura do direito. No entanto, até aqui, apenas analisei os reflexos dessa tentativa de transformação da estrutura do direito na redefinição da aplicação da lei. Passarei, a partir de agora, a examinar os resultados dessa proposta de revisão estrutural sobre a própria organização do desenho institucional e, por conseqüência, do modelo de Estado de Direito.

\section{Novas expertises para a burocracia estatal}

Após a Revolução de 1930, o Governo Vargas teria que organizar sua burocracia estatal. As novas necessidades trazidas com o aumento da complexidade social e econômica exigiriam novos profissionais. O país dos bacharéis que haviam governado o Brasil a partir do sistema de oficialato desde o Império até o final da República Velha precisava constituir uma burocracia tecnocrata capaz de lidar com as novas transformações. Não havia no país um sistema de ensino universitário. O planejamento econômico havia sido feito até então por bacharéis do direito como Rui Barbosa. Não havia economistas. Somente em 1934, são criadas as primeiras universidades de grande porte $^{176}$ : Universidade do Distrito Federal e Univesidade de São Paulo.

${ }^{175}$ De acordo com Danilo Zolo, o rule of law "não é, senão muito indiretamente, uma teoria jurídica do Estado, uma sua 'judicialização' ou constitucionalização'. Esse se distancia nitidamente do 'Estado legislativo’ alemão (e, em geral, continental), no qual os juízes são funcionários públicos que aplicam a lei do Estado e os próprios direitos individuais são 'postos' pelo Parlamento. Sob esse perfil, o rule of law, como escreveu Dicey, é a distinctive characteristic of the English constitution" (COSTA, 2006, p. 19).

176 "No plano do ensino superior, o governo procurou criar condições para o surgimento de verdadeiras universidades, dedicadas ao ensino e à pesquisa. Até aquela data, elas eram apenas uma junção de escolas superiores. A Universidade do Rio de Janeiro, por exemplo, criada em setembro de 1920, consistia na verdade em uma agregação de três escolas: a Faculdade de Direito, a Faculdade de Medicina e a Politécnica. Por decretos de abril de 1931, o governo baixou o Estatuto das Universidades Brasileiras e reorganizou a Universidade do Rio de Janeiro, procurando estabelecer as bases do sistema universitário (...) as primeiras medidas de criação das universidades surgiram no Distrito Federal e em São Paulo, neste último caso à margem da participação federal. Assim, nasceram em 1934 a Universidade de São Paulo (USP) e, em 1935, a Universidade do Distrito Federal; esta graças à iniciativa do secretario da Educação Anísio Teixeira. A Universidade do Distrito Federal foi instituída sem contar com as escolas superiores que já existiam e preocupou-se, sobretudo, com a formação de educadores em sua Faculdade de Educação. Seus propósitos inovadores não resistiram ao regime autoritário implantado em 1937. Em 1939, foi extinta e incorporada à Universidade do Brasil, na qual se transformara a Universidade do Rio de Janeiro, desde 1937. Mais abrigada 
$\mathrm{O}$ arquiteto de boa parte dessas mudanças na forma como o Estado brasileiro formaria uma expertise profissional ${ }^{177}$ que deveria compor a nova burocracia estatal foi Francisco Campos, o mais emblemático nome do que se veio chamar de nacionalismo autoritário brasileiro. De acordo com Campos:

\begin{abstract}
“A evolução que sofreu o governo e a concepção das suas funções nestes últimos cinqüenta anos ainda não está terminada. Sob a pressão das situações e emergências criadas pela revolução industrial, em pleno processo de desenvolvimento, o governo procura adaptar a sua máquina, ainda a pouco tempo simples e rudimentar, às complexas operações administrativas indispensáveis ao controle, que se lhe impõe do ponto de vista do interesse público, sobre as novas forças, cuja crescente utilização constitui um dos característicos dominantes da civilização dos nossos dias. De uma agência política, que era no século XIX, o governo passou a ser uma agência administrativa, de funções as mais intrincadas e complexas" (CAMPOS, 1934, p. 187).
\end{abstract}

Francisco Campos também foi um dos autores brasileiros que participaram da deglutição intelectual do realismo jurídico norte-americano. Interessado na reformulação do modelo de cooptação das elites que fariam parte de uma nova burocracia administrativa, que fosse capaz de atuar em um Estado com diferentes funções, Francisco Campos buscava nos realistas sustentáculos que legitimassem uma formação técnica, interdisciplinar e funcionalista, oposta ao bacharelismo liberal e conceitualista. Dentre os autores norte-americanos do Progressive Legal Thought, o que mais interessou Francisco

das tempestades políticas e implantada com maior solidez pela elite paulista, a USP não só sobreviveu como se tornou o principal centro de ensino e pesquisa do país. Sua criação decorreu, por um lado, da existência na capital paulista, desde a Primeira Guerra Mundial, de um vivo debate das principais questões educacionais, com propósitos reformadores; por outro, do fato de os princiapais participantes desses debates, com Fernando de Azevedo à frente, terem firmado posições no aparelho de ensino paulista até o golpe de 1937 (FAUSTO, 2003, pp. 337-338).

177 Outro importante nome para a idealização do novo modelo de ensino e formação do Estado varguista foi Gustavo Capanema, que, no entanto, não se enquadra no objeto de estudo deste trabalho e, portanto, não foi abordado. 
Campos quanto a essa readequação dos papéis do Estado e de seus agentes foi Félix Frankfurter, razão pela qual esse jurista foi diversas vezes citado pelo autor brasileiro, como neste trecho do livro The public and its government ${ }^{178}$ :

"No dia-dia da política contemporânea, as organizações industriais, o controle de utilidades públicas, o bem-estar da agricultura, a repressão ao crime e ao descaso - são profundamente vinculados e intrincados a fatos técnicos e precisam ser libertos de preconceitos e partidarismos. Essas matérias demandam um esforço sistemático para a redução da área de conflito e emoção e ampliação da área de conhecimento reconhecida como base de ação".

\section{A reafirmação do Estado de Direito - a soberania do contencioso judicial}

Apontados os principais fatores que levaram à necessidade de formação da burocracia estatal, passarei a estudar as tentativas de reconfiguração do desenho institucional sob a vertente jurisdicional. A crise da hermenêutica jurídica, atrelada ao formalismo jurídico, tinha como pano de fundo um debate ainda mais complexo, que passava pelo questionamento sobre a adequação do modelo de diferenciação dos poderes $^{179}$. Sob esse aspecto, tanto Estados Unidos, como Brasil, foram observados por seus juristas a partir de uma perspectiva ora questionadora ora conservadora de elementos do Estado consolidados no final do século XIX, tal como o foi a separação de poderes. Esse tema apareceu de modo intenso no debate sobre a possibilidade de ampliação dos

\footnotetext{
178 "For the staples of contemporary politics the organization of industry, the control of public utilities, the well being of agriculture, the mastry of crime and descase - are deeply enmeshed and intricate in technical facts, and must be extricated from pressupposition and partisanship. Such matters require systematic effort to contract the area of conflict and passion and widen the area of acredited knowledge as the bases of action" (FRANKFURTER, pp. 151-152 apud CAMPOS, 1934, p. 188).

${ }^{179}$ De acordo com o professor da Universidade de Florença, Danilo Zolo, a diferenciação do poder é um elemento característico do Estado de Direito e apresenta dois aspectos essenciais: "1) o da autodiferenciação do subsistema político-jurídico em relação aos outros subsistemas funcionais; 2) o da diferenciação interna ao subsistema político, em um processo que aumenta a sua complexidade, especialização e eficiência, dando vida a uma pluralidade de estruturas e modalidades diversas de exercício do poder. Esse processo, como é notório, foi interpretado (e vulgarizado) pela estratégia de 'divisão dos poderes' intencionalmente objetivada ao equilíbrio entre os órgãos do Estado(...)” (COSTA, 2006, p. 43).
} 
poderes da burocracia estatal para adjudicar conflitos sem o controle do contencioso judicial, fortalecendo-se, assim, um contencioso administrativo. Tratava-se de um problema até então novo para a tradição anglo-saxã, mas já conhecido dos países que, como o Brasil, já haviam adotado, em um momento não tão longinqüo de sua história, o modelo francês de contencioso administrativo (Conselho de Estado ${ }^{180}$ ). Para explicar melhor essa questão, passarei a analisar os contornos desse debate nos Estados Unidos e no Brasil dos anos 1930.

\section{Contexto norte-americano}

Durante o período do New Deal, e, em especial, após 1935, quando a Suprema Corte declarou a inconstitucionalidade do National Industrial Recovery Act, no caso Schecter Poultry, ressurgiu ${ }^{181}$ nos Estados Unidos o debate entre duas diferentes tradições acerca da divisão de funções reguladoras e adjudicatórias entre o Governo e o Judiciário. De um lado, James M. Landis, a vertente cientificista e, de outro, Roscoe Pound e a American Bar Association, a vertente legalista (HORWITZ, 1992, pp. 213-221).

James M. Landis aposentou-se, em 1937, da presidência da Securities and Exchange Commission, para se tornar o mais jovem Dean da história da Faculdade de Direito de Harvard. Seu livro mais famoso, The Administrative Process, é uma defesa do contencioso administrativo norte-americano. James Landis defendia a tradição cientificista, cujos antecessores tinham sido John Dickson, em 1927, e Frank Goodnow, em 1905.

180 O Conselho de Estado recriado pela Lei $\mathrm{n}^{\circ} 234$, de 23 de novembro de 1841 e organizado por seu regimento provisório, o Regulamento $\mathrm{n}^{\circ} 124$, de 5 de fevereiro de 1842, foi uma das mais importantes instituições durante o Segundo Reinado, tanto devido ao seu papel político, como ao seu papel de contencioso administrativo. A Lei $\mathrm{n}^{\circ} 234$, de 1841, que recriou o Conselho de Estado, estabeleceu em seu art. $7^{\mathbf{o}}$ as suas competências. Assim, "incumbe ao Conselho de Estado consultar em todos os negócios em que o imperador houver por bem ouvi-lo para resolvê-los; e principalmente: $1^{\circ}$ ) Em todas as ocasiões em que o Imperador se propuser exercer qualquer das atribuições do Poder Moderador, indicadas no art. 101 da Constituição; $2^{\circ}$ ) Sobre declaração de guerra, ajustes de paz e negociações com as nações estrangeiras; $3^{\circ}$ ) Sobre questões de presas e indenizações; $4^{\circ}$ ) Sobre conflitos de jurisdição entre as autoridades administrativas e entre estas e as judiciárias; $5^{\circ}$ ) Sobre abusos das autoridades eclesiásticas; $6^{\circ}$ ) Sobre decretos, regulamentos e instruções para a boa execução das leis e sobre propostas que o Poder Executivo tenha de apresentar à Assembléia Geral" (grifo meu).

${ }^{181}$ O mesmo debate já havia surgido com o Interstate Commerce Act, em 1887, e com o Federal Trade Commission Act, em 1914 (HORWITZ, 1992, pp. 222-223). 
Para Landis, os juízes eram ideológica e administrativamente inábeis para solucionar os problemas regulatórios de uma sociedade industrial cada vez mais complexa e interdependente. Para o autor cientificista, especialmente nas áreas relacionadas à regulação econômica, como regulação da concorrência e das relações de trabalho, "não havia confiança na habilidade dos tribunais para estabelecer conceitos funcionais aptos a dirigir as forças econômicas envolvidas nesses problemas" ${ }^{182}$ (LANDIS, 1938, pp. 32-33). A solução para essa inaptidão dos tribunais para solucionar casos de natureza regulatória estaria, na visão desse autor, na expansão do processo de ampliação da regulação administrativa federal iniciada desde 1887 com a criação da Comissão de Comércio Interestadual (Interstate Commerce Comission) (HORWITZ, 1992, p. 214).

Roscoe Pound, por outro lado, era um defensor do Estado de Direito (rule of law). Seguia a tradição de Albert Venn Dicey ${ }^{183}$, o famoso professor de Oxford e autor do clássico Introduction to the Study of the Law of the Constitution (1885), no qual distinguia o sistema de direito administrativo francês do sistema de determinação de poder judicial sobre os administradores (regular law), demonstrando como o modelo francês favorecia a arbitrariedade e o modelo inglês privilegiava o regular law ${ }^{184}$. Dicey enfatizava a unicidade da legislação e da jurisdição, que não só eram fundamentais para o seu conceito de rule of law, como também eram também instrumentais no embate contra o direito administrativo (SANTORO, 2006, p. 220). Essas premissas de Dicey foram imensamente utilizadas por Pound em sua crítica ao que chamava de "absolutismo da administração" (“administrative absolutism") (HORWITZ, 1992, p. 220). Pound, portanto, era totalmente contrário à idéia de regulação administrativa, com a quebra da unicidade da jurisdição.

Nessa crítica aos tribunais administrativos, Roscoe Pound reafirma sua tentativa de aproximar as teorias da justiça do sentido prático do direito. Fica evidente, nesse ponto, que a crítica de Pound aos tribunais administrativos passava por sua crença no rule of law e

\footnotetext{
182 "There was widespread distrust of the courts' ability to evolve workable concepts to direct the economic forces which had posed these problems" (LANDIS, 1938, pp. 32-33).

${ }^{183}$ Law and Public Opinion (1905).

${ }^{184}$ Esse ataque ao que os legalistas chamavam "absolutismo administrativo" teve ainda o apoio do Chief Justice da Inglaterra, Lord Hewart, autor de New Despotism, publicado em 1929 (HORWITZ, 1992, pp. 225227).
} 
por sua idéia forte de justiça. Em um texto publicado em português em 1976, Justiça Conforme à lei, Pound afirmou que:

"não se exige dos juristas que proclamem greve de braços cruzados até que os filósofos se ponham de acordo, se algum dia o conseguirem, a respeito de uma teoria de valores ou definição de valores ou definição de justiça. A experiência resultante da razão verificada pela experiência ensinaram-nos como prosseguir em busca da realização da tarefa prática, que permita aos homens viverem juntos, em comunidades politicamente organizadas (...) mediante a orientação de uma idéia atuante, mesmo que tal idéia não seja convicententemente ideal pela metafísica, pela lógica ou pela moral (...). Dicey assinalou-o há muito (...) nas questões trabalhistas, certa tolerância da desordem constitui necessidade prática, mesmo quando a lógica recomenda aplicação rigorosa de regras fixadas pela lei. Mas nem por isso se conclua que nosso recurso único está na expressão arbitrária da vontade do legislador, por um lado, ou na determinação arbitrária de algum órgão administrativo, por outro. É possível aproximar-nos, para fins práticos, de ajustamentos sistemáticos e regulações razoáveis de conformidade com certa técnica de autoridade. Denominei tal processo de engenharia social" (POUND, 1976, pp. 31$32)$.

Assim, apresentei como foi traçado o debate sobre o redesenho institucional norteamericano a partir de dois pontos de vista bastante distintos. De um lado, James Landis e a defesa da legitimidade de órgãos administrativos com função adjudicatória e, de outro, Roscoe Pound e a defesa do rule of law como única forma de se efetivar a engenharia social do modo mais próximo possível de um conceito aberto, mas não arbitrário, de justiça. O próximo passo será estudar como se deu a discussão em torno da mesma temática no Brasil dos anos 1930. Apesar de a vertente legalista de Pound ter sido muito mais difundida, argumentos semelhantes ao cientificismo norte-americano também apareceram. Apresentarei, a partir de agora, os deslindes desse embate entre os juristas brasileiros. 


\section{Contexto brasileiro}

Assim como nos Estados Unidos houve o debate entre o legalismo de Roscoe Pond e o administrativismo de James Landis, no Brasil também houve o confronto entre a possibilidade de existir um contencioso administrativo ao lado de um contencioso judicial. Tratava-se de uma das discussões em torno da reformulação do desenho institucional brasileiro após a Revolução (ou golpe) de 1930 e tinha como núcleo a necessidade de criação de novos órgãos administrativos capazes de enfrentar os novos desafios econômicos e sociais (questão industrial e questão social), o que fazia com que os juristas tivessem que reler o conceito de separação de poderes.

O interessante, aqui, é que justamente Francisco Campos, um dos principais pensadores e articuladores políticos do Governo Vargas, foi um dos maiores defensores da supremacia do contencioso judicial. Para Campos, na verdade, as Constituições republicanas somente admitiam a existência do contencioso judicial, marginalizando o contencioso administrativo. Mesmo admitindo a possibilidade de se conferir a determinados departamentos de Estado, como o Conselho Nacional do Trabalho e as Caixas de Pensões e Aposentadorias, a função de decidir determinados conflitos, tais decisões estariam sempre sob a possibilidade de revisão do Judiciário.

Em seu parecer, Exercício, pela Administração, de Funções de Natureza Judicial, escrito em 1934, mas publicado em 1943, Francisco Campos utilizou-se das soluções da Suprema Corte para o problema da concorrência entre função contenciosa administrativa e judicial. Para tanto, o autor citou os casos Bates \& Guild C. v. Payne ${ }^{185}$ e New York v. Mc. Call, bem como a posição de Freund sobre o tema, para concluir que, mesmo nos Estados Unidos, a função contenciosa havia sido preservada como uma prerrogativa do Judiciário:

"Se, portanto, ainda nas questões de fato, com o declarar a lei serem conclusivas e finais as decisões da Administração a elas relativas, o Poder Judiciário não se julga inibido de entregar na sua apreciação, revendo-se

${ }^{185} 194$ U.S. 106 
não só quanto às evidências, mas também quanto ao processo por que foram obtidas ou constituídas tais evidências e ao critério que presidiu a sua aferição, inútil se torna acentuar que sobre as questões de direito se estende, em toda a sua latitude, e sem limitação de espécie alguma, a competência do Judiciário" (CAMPOS, 1943, p.21).

Francisco Campos ainda acrescentou ao seu parecer a citação de um longo trecho do levantamento de Roscoe Pound, publicado no Journal of the American Judicature Society, de outubro de 1927 (pp. 69-70), sobre o mapa da jurisdição dos tribunais americanos, comparando seus limites com a área de atuação do Governo norte-americano:

"Ao mesmo tempo, nós desenvolvemos um sistema de interferência judicial com a administração. A lei paralisando a administração era um espetáculo diário. Quase todas as medidas importantes de polícia ou administração encontravam uma proibição. Nós nos baseamos em demandas tributárias para prevenir o desperdício de fundos públicos e o uso inadequado dos recursos de impostos. Em muitas jurisdições não era incomum ver a cobrança de taxas necessárias para a condução diária dos negócios públicos ser restrita por proibição. Em caso de perturbação da paz, o indivíduo e até mesmo, em um único caso, a Nação, tinham que apelar para a proteção de sua propriedade e de seus negócios, não à polícia ou às autoridades administrativas, mas aos tribunais de eqüidade (...). Parece que nós atingimos na realidade um Rechstaat. Nosso governo era um governo de lei e não de homens. A administração havia se tornado 'apenas subordinada ao processo de governo como um todo'. A eliminação completa do fator pessoal em todos os assuntos que afetam a vida, liberdade, patrimônio ou fortuna do cidadão parece ter sido atingida. O que em outros locais estava atribuído à administração, à inspeção e à supervisão executiva, nós deixamos para os tribunais (...). Nada é tão característico da lei pública americana da última metade do século XIX quanto a integridade com a qual a ação do Executivo é 
vinculada pela responsabilidade legal e revisão judicial"186 (POUND, 1927, pp. 69-70; CAMPOS, 1943, pp. 22-23).

Assim, apesar de Francisco Campos ser um dos principais homens da burocracia do Estado varguista, defendia o fortalecimento do Judiciário, em posição completamente contrária ao que defendia, nos Estados Unidos, James M. Landis, o burocrata por excelência do governo FDR. A razão disso pode estar relacionada ao fato de que, o Judiciário brasileiro, diferentemente do que ocorreu nos Estados Unidos, não representou um problema para o Governo, nem para a implantação de suas políticas.

Destaco que a visão de Francisco Campos em relação aos conflitos de atribuição entre Executivo e Judiciário era bastante diferente daquela defendida por Oliveira Vianna em relação aos conflitos de poder entre Executivo e Legislativo no caso da lei de organização da Justiça do Trabalho. Ao defender uma mudança na forma como os tribunais interpretavam a lei, Oliveira Vianna buscava uma ampliação dos poderes do juiz ao aplicar a lei. Provavelmente, os motivos para essa diferença de postura em relação ao Judiciário e ao Legislativo estejam na desconfiança que os homens de Vargas tinham com a representação parlamentar. O Judiciário não representava, como havia representado em vários momentos durante a República Velha ${ }^{187}$, uma força política de oposição ao governo. Além disso, assim como o Executivo, o Judiciário era composto por um corpo burocrático, recrutado a partir de instrumentos meritocráticos. O Legislativo representava o poder dos

\footnotetext{
186 "At the same time, we have developed a system of judicial interference with administration. Law paralyzing administration was an every-day espetacle. Almost every important measure of police or administration encountered an injunction. We relied on taxpayers' suits to prevent waste of public founds and misure of the proceeds of taxation. In many jurisdictions it was not uncommon to see collection of taxes needed for every-day conduct of public business retrained by injunction. In case of disturbance of the peace, the individual and even, in one single instance, the nation had come to appeal, for the protection of property and business, on to the police or to the administrative authorities, but to courts of equity (...). We seemed to have achieved in very truth a Rechtstaat. Our government was one of laws and noto $f$ men. Administration had become 'only a very subordinated in the whole processo of government'. Complete elimination of the personal equation in all matters affecting the life, liberty, property or fortune of the citizen seemed to have been attained. What in other lands was committed to administration and inspection and executive supervision, we left to courts (...). Nothing is so characteristic of American public law of the last half of the nineteenth century as the completeness with wich executive action is tied down by legal liability and judicial review" (POUND, 1927, pp. 69-70 - original; CAMPOS, 1943, pp. 22-23).

${ }^{187}$ Durante a República Velha, o Judiciário, em especial na primeira instância, tendia a decidir contra o Estado e a favor dos particulares nas questões envolvendo a regulação econômica.
} 
"clãs regionais", associados ao sistema de poder da República Velha combatido pelo nacionalismo autoritário de Vargas.

Além de citar autores do realismo norte-americano para contestar o formalismo jurídico, Vianna também buscou nas críticas da sociological jurisprudence de Pound à mechanical jurisprudence respostas para a sua defesa dos tribunais administrativos. De acordo com o autor brasileiro:

\footnotetext{
"Procurando a razão íntima (...) desta evolução, Pound vê nella - nesta evasão ao formalismo e ao direito estricto, ao 'cumbrous, ineffective and unbusinesslike legal procedure', como elle mesmo diz - uma reversão aos regimes da 'justiça sem lei' (justice withou law). Para elle, esta ‘justiça sem lei’ é própria aos períodos agitados, em que as sociedades entram em phase de desequilíbrio e instabilidade. Os períodos estáveis, de ajustamento e equilíbrio, só estes se compadecem com um regime de formalismo jurídico, de direito estricto - de justiça de acordo com a lei (justice acording to law). Nas sociedades modernas, todas ellas atravessando uma phase de desequilíbrios e desajustamentos profundos, principalmente no campo econômico, a administração da justiça, isto é, a solução jurisdiccional dos conflitos suscitados por estes mesmos desajustamentos tem que se fazer por processos fora dos ritos rígidos e complexos dos tribunais de direito comum. Ora, somente os tribunais administrativos, justamente por estarem libertos deste formalismo e da applicação mechanica das regras de direito (mechanical jurisprudence), tem plasticidade e adaptabilidade para relaizar estes objectivos" (VIANNA, 1938, pp. 56-57).
}

Nesse trecho do texto Problemas de Direito Corporativo (1938), Oliveira Vianna cita o livro The administrative application of legal standarts (1930), de Roscoe Pound (POUND, 1930, p. 113), para legitimar a criação de tribunais administrativos. Conforme analisei, a posição de Pound quanto a esse tema era bastante diferente daquilo que defendia Vianna. Ao contrário do autor brasileiro, Pound acreditava na supremacia do Estado de 
Direito e era absolutamente contrário à ampliação do contencioso administrativo. Nesse sentido, diferentemente do papel de Brandeis na obra de Vianna, Pound acaba sendo utilizado apenas como elemento de legitimação de seu discurso. No próprio texto de Vianna, acima transcrito, evidencia-se o fato de que Pound associava a ausência do due process of law aos períodos de instabilidade constitucional de modo descritivo e não prescritivo como pretendia o autor brasileiro. Desse modo, Oliveira Vianna atribuiu à descrição de Pound sobre a relação entre o devido processo legal e a estabilidade constitucional caráter propositivo, gerando um resultado incongruente com as idéias do autor norte-americano.

Esse excerto também é ilustrativo de uma grande diferença entre Pound e Vianna. Ao contrário de Pound, Vianna era cético quanto ao resultado justo e previsível do devido processo legal. Nesse sentido, o autor brasileiro aproximar-se-ia mais do adversário norteamericano do velho Pound: o jovem Karl Llewellyn. Assim, ao contrário de outros nacionalistas autoritários, como Alberto Torres e Francisco Campos, Oliveira Vianna desenvolveu um ceticismo exacerbado que o aproximou bastante do realismo jurídico norte-americano, mesmo que, dentro de seu ecletismo muitas vezes pouco rigoroso, Vianna se utilizasse do discurso da sociological jurisprudence para vencer suas contendas políticas.

Entretanto, esse debate a respeito da atribuição da função de adjudicação das leis ultrapassou a Era Vargas e a antropofagia realista foi além dos juristas do período entre guerras. Em 1959 (ano da Revolução Cubana), quase 15 anos após o final da Era Vargas, Francisco Sá Filho, professor da Pontifícia Universidade Católica do Rio de Janeiro e procurador-geral da Fazenda Pública, escreveu o livro Relações entre os Poderes do Estado. Nessa obra, Francisco Sá analisou o debate norte-americano a respeito da relação entre Judiciário e Executivo, reconstruindo alguns dos embates protagonizados por prérealistas, como Oliver Wendell Holmes e Roscoe Pound, e realistas como Louis Brandeis. Além disso, Sá, ao analisar os métodos de interpretação, apontou o papel do método sociológico/pragmatista. Ressalto, entretanto, que, em nenhum desses momentos, Sá falou sobre a Escola Realista (no entanto, falou de autores realistas norte-americanos), mas em vários deles identificou a existência de um grupo de autores preocupados com modelos de 
interpretação constitucional "mais vivos", menos formais e mais voltados para a realidade social e econômica (SÁ, 1959, pp. 314-315).

Ao final de seu texto, Sá retomou o debate entre Oliveira Vianna e Waldemar Ferreira sobre a natureza judicial ou administrativa da Justiça do Trabalho. No entanto, não reorganizou os termos do debate, nem apresentou o uso que Oliveira Vianna fez dos realistas. Desse modo, apenas se utilizou desse debate como pano de fundo para tratar do caráter regulamentar da Justiça do Trabalho. Sá defendia que sobreposição entre Executivo e Judiciário não era um problema em si, criticando o que no Brasil foi definido como "o princípio de que nenhuma questão pode ser subtraída ao julgamento do Judiciário" e a "indelegabilidade de poderes"188, que teriam como fundamentação o "temor da ditadura presidencial", de tal modo que seriam "concessões ao regime, que assim, se mostra obstáculo ao progresso jurídico" (SÁ, 1959, p. 257).

Roscoe Pound e Alípio Silveira - a condensação do diálogo entre Brasil e Estados Unidos sobre interpretação e desenho institucional

Os reflexos do discurso do conteúdo questão social sobre a estrutura do direito apareceram condensados na obra de Roscoe Pound. Esse autor estudou tanto a aplicação do direito sob a perspectiva da Escola Livre e da Sociologia de Geny e Ehrlich ${ }^{189}$, como se dedicou à análise da organização do desenho institucional norte-americano, atentando-se, especialmente, para as propostas de expansão da atribuição da administração para

\footnotetext{
${ }^{188}$ No entanto, em um parecer de 27 de julho de 1940 (Processo $n^{\circ}$ 90.849-36), em processo que tratava sobre a regulação orçamentária, Sá escreveu sobre a incompetência da administração para julgar a inconstitucionalidade das leis. De acordo com o autor: "a superlegalidade constitucional ou o controle de constitucionalidade das leis atribuído exclusivamente ao Judiciário, iniciado nos Estados Unidos, transplantado para o Brasil, só em data recente, se vem ampliando a outros países (...). Arrogar-se qualquer outro órgão público, o julgamento da constitucionalidade das leis, seria o tumulto, a desordem, a anarquia. Mesmo na América do Norte, que se orgulha dessa criação, têm surgido autorizadas críticas, à sua execução, no que toca às leis sociais e aos regulamentos do New Deal. Jamais se cogitou de ampliar, senão de restringir, a faculdade exclusivamente judiciária, de apreciar da constitucionalidade das leis. A Administração não pode, pois, deixar de cumprir o dispositivo orçamentário que reduziu os vencimentos do requerente, cuja pretensão não merece acolhida" (SÁ, 1942, pp. 399-400).

189 Embora Pound tenha sido considerado a versão anglo-saxônica da sociologia jurídica de Ehrlich, é importante perceber que há diferenças significativas entre os dois autores. De acordo com Clarence Morris, a “"sociologia do direito' de Ehrlich possui uma base social mais ampla do que a 'engenharia social' de Pound, mais pragmática" (MORRIS, 2002, p. 1).
} 
adjudicar conflitos. No Brasil, Alípio Silveira, também influenciado por Geny e Ehrlich, tentava compreender a aplicação do direito a partir de qual regime de governo se encontra no poder, examinando, para tanto, o papel da interpretação da lei dentro de diferentes organizações institucionais.

Alípio Silveira foi especialmente influenciado por Roscoe Pound, a principal liderança da Sociological Jurisprudence. O mais interessante é que Silveira, de fato, estabeleceu um diálogo com Roscoe Pound. Foi o único autor brasileiro que teve sua obra analisada por Roscoe Pound. O prefácio do livro de Silveira, O Fator Político-Social na Interpretação das Leis (1946), foi escrito por Roscoe Pound. Para que isso ocorresse, Silveira fez uma versão síntese de seu livro em inglês, texto que serviu de base para os comentários de Pound. A versão final do livro de Silveira traz o prefácio de Pound em inglês e a sua tradução para o português.

De um modo geral, Silveira e Pound compartilhavam a mesma visão sobre as transformações nos métodos jurídicos, já amplamente expostas nos itens anteriores. Ambos, ainda, parecem discordar da instituição de órgãos administrativos de adjudicação, defendendo que tanto o Brasil como os Estados Unidos tinham como premissa de seu ordenamento jurídico a unicidade da jurisdição. De acordo com o prefácio de Pound ao livro de Silveira:

"Não existia no sistema legal anglo-americano direito público no sentido em que o direito Romano moderno (isto é, os sistemas de codificação) entende este termo. Nos Comentários de Blackstone (1765) o direito relativo aos agentes do governo foi colocado como um ramo do direito privado - a parte do direito das pessoas que tratava das pessoas investidas de autoridade governamental, sujeitas à lei da terra, como o eram todas as pessoas em suas múltiplas atividades. Estamos precisando fazer uma revisão de nossas idéias em face da transformação de uma sociedade pioneira, rural e agrícola, em outra, urbana e industrial. Mas esta transformação tem se processado em proporções variáveis nas diferentes partes dos Estados Unidos e de nenhum modo está completa em todo o país. Seu efeito sobre a interpretação exerce-se principalmente sobre a 
interpretação e aplicação dos textos constitucionais e neste ponto levantam-se questões semelhantes àquelas de que trata Alípio Silveira. Entre nós, havia a princípio a idéia de que o fim do direito era assegurar as espectativas razoáveis (direitos) dos indivíduos, os 'direitos naturais'. Posteriormente, surgiu a idéia de que o fim da lei era tornar possível um máximo de livre iniciativa individual. Era esta a idéia dos juristas metafísicos da Europa continental do século passdo. Outras idéias, de elaboração menos clara, têm sido sustentadas ultimamente. A que tem sido mais claramente exposta e vigorosamente defendida, é a de que o fim do direito é simplesmente manter a ordem social assegurando a ordem política e econômica do tempo e do lugar. Não redunda a tese de Alípio Silveira naquela da influência do ideal predominante quanto ao fim da ordem legal, sobre o procedimento administrativo e judicial, no que toca ao modo em que se aplica o direito considerado como o conjunto dos fundamentos admitidos ou recebidos e das diretivas da decisão? O surgir de tribunais administrativos como um incidente do desenvolvimento da idéia que concebe o Estado antes como uma instituição para serviço do que simplesmente um instrumento para manter a segurança geral, está a exigir que repensemos muitos pontos sobre os quais nossas idéias jurídicas anglo-americanas já se tinham estratificado. Isto é especialmente notável no que toca a nossa doutrina fundamental da supremacia do direito" ${ }^{190}$ (POUND, 1949, pp. XXII-XXIII - tradução de Alípio Silveira).

\footnotetext{
190 "There was in the Anglo-American legal system no public law as the modern Roman law understood that term. In Blackstone's Commentaries (1765) the law as to public officers was put as a branch of private law that part of the law of persons which had to do with persons invested with governmental authority subjected to the law of the land as all persons were in their several activities. We are having to revise our ideas in face of the change from a pioneer, rural, agricultural society to an urban, industrial society. But that change has gone on at varying rates in different parts of the United States and is by no means complete for the whole country. Its effect upon interpretation is chiefly as to interpretation and application of constitutional texts and as to them raises much of the sort of questions to which Sr. Silveira addresses himself. With us, there was at first an idea of the end of law as securing the reasonable expectations (rights) of individuals as "natural rights'. Later, there was an idea of the end of law as making possible a maximum of free individual selfassertion. This was the idea of the metaphysical jurists of Continental Europe in the last century. Other ideas not so clearly worked out have been urged of late. One which has been most clearly put and vigorously urged is that the end of law is simply to maintain the social order by securing the political or the economic order of the time and place. Does not Sr. Silveira's question get down to one of the influence of the received ideal of the end of the legal order upon the judicial and administrative process in the way in which they apply law in the sense of the body of received or established grounds of our guides to decision? Rise of administrative tribunals as an incident of development of the idea of the state as an institution for service rather than merely an agency of maintaining the general security is requiring us to rethink many points on which our Anglo-
} 
Do mesmo modo, Alípio Silveira e Roscoe Pound também compartilhavam uma visão crítica a respeito da influência do governo sobre as decisões judiciais e da função da lei como instrumento de atuação do Estado. De acordo com Pound:

"Seria ocioso referirmo-nos hoje em dia à idéia da administração da justiça a modo dessas máquinas automáticas: ponham-se os fatos no orifíco de entrada, puxe-se uma alvanca, e retire-se a decisão predeterminada. Houve o vão empenho, no século dezenove, em todos os sistemas, de conformar o procedimento judiciário a esta teoria. Uma natural reação veio exigir uma mudança radical no procedimento judiciário: a substituição daquele sistema pela norma pessoal e subjetiva do juiz guiado, quando muito, por um conceito geral do bem comum. Mas a teoria mecânica tinha o bem comum em vista. Acreditavam seus autores que o bem comum consistia em manter as liberdades individuais. Não é fácil dizer exatamente em que consiste o bem comum, tal como existe na consciência dos homens de hoje. Muitas vezes parece que os que denominam a si próprios realistas supõem-no ser um poder absoluto dos agentes do governo, exercido como um fim em si. Seja como for, nos absolutismos políticos de hoje, o ideal consiste, não em agirem os governos de acordo com o direito, ideal esse do direito anglo-americano, mas em governarem eles através do direito. Tais absolutismos concebem o direito como instrumento da ação governamental e não como a diretriz dos poderes estatais ${ }^{191}$ (POUND, 1949, p. XXIII - tradução de Alípio Silveira).

American juristic ideas has become settled. This specially notable as to our fundamental doctrine of supremacy of law" (POUND, 1949, pp. XXVIII-XXIX - original).

191 "Nothing need be said nowadays of the idea of a slot machine administration of justice; put the facts in the slot, pull a lever, and pull out the pre-appointed decision. There was a vain endeavor in the nineteenth century in all systems to make the judicial process conform to this theory. A not unnatural reaction has been calling for a turning of the judicial process entirely at large; for substituting the person, subjective standard of the individual judge guided at most by a general notion of the public good. But the mechanical theory had the public good in view. Its proponents believed that the public good consisted in maintaining individual liberties. Exactly in what the public good is to be taken to exist as men think today is not easy to say. Often it seems as if the self-styled realists assume it to be absolute power of officials for its own sake instead of absolute freedom of individual action for its own sake. At any rate, in recent political absolutism the ideal is not officials governing according to law, which has been the ideal of Anglo-American law, but officials 
Dessa forma, Roscoe Pound responde às críticas que havia recebido dos realistas norte-americanos pós-Llewellyn e Frankfurter denominando esse movimento de absolutismo jurídico. Defende, assim, a autonomia dos juízes em relação à Administração e o controle das decisões desses juízes pela fundamentação de seu raciocínio jurídico.

De igual modo, no primeiro ano após o fim do Estado Novo, Alípio Silveira associa as mudanças no discurso brasileiro sobre a hermenêutica jurídica durantes os 15 anos que antecederam sua principal obra às transformações nos regimes políticos. Embora tenha dado ao seu trabalho um caráter universal, explicando como os regimes politicos ${ }^{192}$ totalitários (soviético, fascista e nazista) e liberais (norte-americano) tiveram influência sobre a teoria da interpretação judicial, também converte em crítica local essa abordagem global, ao concentrar seu objeto de análise na Lei de Introdução ao Código Civil de 1942, ao associar o Estado de Vargas com a questão social e as mudanças da LICC de 1942 com o modo como se pretendeu impor esse conteúdo à decisão judicial.

Portanto, tanto Pound como Silveira convergiam no sentido de que os mecanismos de adjudicação dos conflitos e de interpretação da lei deveriam ser mantidos de modo independente do controle do regime político que estivesse no poder. Esse processo, no entanto, não ocorreria de modo natural, uma vez que os regimes político-sociais necessariamente exerceriam algum tipo de influência sobre os juízes. Torna-se, então, necessário compreender tais processos de interferência, com o objetivo de circunscrevê-los dentro de uma lógica que preserve o equilíblio de forças entre os poderes.

governing through law. It conceives of law as the instrument of official action, not as the guide of official action" (POUND, 1949, p. XXIX - original).

192 "Vimos que, no regime liberal, o fim do Estado é a proteção dos direitos individuais. Quer dizer, os direitos individuais estavam situados acima do Estado, que não passava de mero instrumento para sua realização. Nos Estados Totalitários somos surpreendidos por característica e completa inversão: o Estado supera ou suprime os direitos individuais, ao mesmo tempo que altera a própria concepção do Direito. Como conseqüência, a função do direito, em sua nova concepção, quer se trate do direito substantivo, quer do adjetivo, é realizar os fins do Estado (...). A interpretação da lei há de, por força, seguir essa mudança de concepção ou conteúdo da lei, mudança essa essencialmente conexa ao regime politio-social. Em conseqüência, a função máxima ou suprema da interpretação, nos regimes totalitários, é realizar os novos fins do Estado fins esses divergentes dos do Estado liberal” (SILVEIRA, 1946, p. 265). 
O próximo e último passo deste trabalho será examinar o que restou da antropofagia brasileira ao Progressive Legal Thought norte-americano com a queda do regime político-social instaurado durante a Era Vargas. 


\section{A QUEDA DO ESTADO NOVO E A ANTROPOFAGIA REALISTA}

Não há uma ou duas razões que expliquem a descontinuidade da leitura do realismo jurídico norte-americano no Brasil. Algumas hipóteses, contudo, podem ser apresentadas. A redemocratização de 1945 significou também a exortação de toda e qualquer idéia que representasse o Estado autoritário de Getúlio Vargas. A leitura de Oliveira Vianna e por consequiência, a de Alberto Torres, passou a ser associada ao autoritarismo e ao fascismo. O mesmo ocorreria com Francisco Campos. Preconizava-se um Estado democrático de direito, que tivesse uma idéia pré-moldada de justiça. $\mathrm{O}$ realismo jurídico perdera sua função no direito constitucional brasileiro.

A própria questão social sofreu um processo de refração, ao menos da forma como esta havia sido tratada durante o período entre guerras. Tendo sido incorporada ao direito, como queriam os "realistas brasileiros", acabou se transformando em mais uma especialidade repleta de formalismos do que uma temática da pauta constitucional. A partir da década de 1950, o direito do trabalho no Brasil passou a ser visto de maneira bastante independente da Constituição. Nesse ponto, a autonomização da Justiça do Trabalho, cujo embrião está certamente em Oliveira Vianna, pode ter tido um papel decisivo. Ao contrário do que se pretendia, essa separação da Justiça do Trabalho em relação à Justiça comum procedimentalizou as relações entre o capital e o trabalho, criando uma expertise jurídica muito mais próxima ao conceitualismo do que ao realismo jurídico.

Nesse sentido, a antropofagia realista do período entre guerras fracassou. Diferentemente dos Estados Unidos, onde o debate central da transformação da posição da Suprema Corte em relação ao Estado de bem-estar-social (Welfare State) deu-se em torno da regulamentação das relações de trabalho (de Lochner a Parrish), esse processo, no Brasil, acabou reproduzindo a lógica formalista que já acompanhava o direito privado. Em vez de se submeter o Código Civil (1916) da Primeira República e o contrato de locação de serviços a uma ótica que envolvesse o debate constitucional sobre a regulação das relações de trabalho, acabou-se por se submeter a questão social à lógica dos Códigos e do conceitualismo. Mesmo que a identificação de um pólo hipossuficiente na relação contratual trabalhista tenha significado uma parcial ruptura com o individualismo liberal do Código Civil de 1916, manteve-se, com a Consolidação das Leis do Trabalho (CLT), o 
mesmo legalismo formalista que havia gerado a oposição de Alberto Torres a Rui Barbosa, de Oliveira Vianna a Waldemar Ferreira, de João Mangabeira aos liberais.

Dos norte-americanos, sobreviveria Roscoe Pound, na leitura dos autores preocupados com o tema da interpretação/ hermenêutica. Se os realistas, completamente céticos em relação à possibilidade de identificação de um conteúdo interpretativo para o direito, foram deixados de lado com o fim do Estado Novo, a sociologia jurídica de Roscoe Pound ainda permaneceria como uma teoria do direito no processo antropofágico brasileiro. 


\section{CONCLUSÃO}

A questão social foi o grande tema do período entre guerras. Assim como os movimentos de trabalhadores das mais variadas vertentes políticas, tais como os anarquistas, anarco-sindicalistas, comunistas e socialistas e que desejavam romper com a ordem econômica capitalista, internacionalizavam-se (a Internacional Socialista), também se tornavam transnacionais os debates entre aqueles que buscavam preservar o sistema capitalista a partir de novos mecanismos de controle e regulação. Dentre esses últimos estavam os juristas, legitimadores por excelência do status quo. Percebia-se que as formas tradicionais de regulação das relações entre empregadores e empregados, bem como a ausência de garantias aos trabalhadores quando não estivessem mais aptos a trocar sua força de trabalho por salário, eram falhas do sistema e poderiam gerar a sua falência. As externalidades negativas do capitalismo industrial poderiam causar sua superação e, para que isso não ocorresse, as teias sociais e econômicas teriam que ser redefinidas, assim como teriam que ser redefinidos os aparatos jurídicos de legitimação do sistema.

Diante desse quadro, o direito oitocentista, garantidor da ordem liberal, passava a ser visto como um instrumento ultrapassado e ineficiente para regular as novas relações. $\mathrm{O}$ privatismo e o individualismo sustentados por uma ordem jurídica liberal teriam que ser substituídos por uma mentalidade associativa e corporativa, bem como o laissez-faire e o Estado liberal (o que não significa que esse Estado liberal não interviesse constantemente na regulação econômica) deveriam ser substituídos por um Estado mais presente na regulação das relações sociais.

No centro do capitalismo mundial estavam os Estados Unidos da América. Ao mesmo tempo em que geravam um crescimento econômico impressionante, o fordismo/taylorismo e a Segunda Revolução Industrial também promoviam um esgarçamento das relações entre capitalistas e a mão-de-obra. Um país marcado pelo trágico histórico da escravidão teria que enfrentar novamente um esfacelamento do motor do sistema de produção: a mão-de-obra. A solução encontrada pelo concerto de elites que governava o país era a repressão policial. Foi em Chicago a mais marcante de todas. Não 
por acaso, foi a partir daí que se instituía o dia $1 .^{\circ}$ de maio ${ }^{193}$ como símbolo dos movimentos em defesa dos trabalhadores. A repressão policial como política de controle das greves e dos sindicatos era referendada pelos tribunais e em especial pela Suprema Corte. A mesma Suprema Corte vetava as medidas dos estados em prol da regulamentação das horas e condições de trabalho, qualificando-as como inconstitucionais. Era o período do paradigmático caso Lochner em 1905. Prevalecia no meio jurídico o mecanicismo, legitimado no universo acadêmico pelas teorias de Langdell. A voz dissonante na Suprema Corte era a de Oliver Wendell Holmes, crítico à legitimação jurídica do liberalismo econômico e ao mecanicismo judicial. A voz dissonante na Academia era Roscoe Pound, o principal autor da Sociological Jurisprudence.

A crise de 1929, deflagrada pelo crash da bolsa de New York, atingiu em cheio a economia norte-americana e fragilizou ainda mais a situação dos trabalhadores. A repressão policial e o liberalismo econômico, ainda conservados pela Suprema Corte, pouco a pouco teriam que ceder às medidas sociais e intervencionistas de FDR. O realismo jurídico de Karl Llewellyn e Jerome Frank buscava, nas revistas jurídicas e na Academia, radicalizar as críticas de Roscoe Pound em relação ao mecanicismo judicial. Os ministros progressistas Benjamin Cardozo e Louis Brandeis lideravam os votos pela reformulação da Corte em prol de uma atitude mais deferente em relação às medidas de proteção social do New Deal. Em West Coast Hotel Co. v. Parrish, finalmente, o New Deal sairia vencedor.

$\mathrm{Na}$ periferia do capitalismo mundial, estavam os Estados Unidos do Brasil. A industrialização tardia, associada a uma abolição tardia do regime escravocrata, também havia relegado a questão social à repressão policial. Muitos dos presidentes da República Velha haviam governado sob estado de sítio ${ }^{194}$. A crise de 1929, as dificuldades para manter os altos níveis de lucratividade com a exportação de café e as novas políticas industriais de Getúlio Vargas fariam com que houvesse um acelerado crescimento industrial no país. Os vários grupos que levaram Vargas ao poder teriam que se acomodar em um concerto político que permitisse a harmonia social.

\footnotetext{
193 O dia $1^{\text {o }}$ de maio foi instituído em homenagem aos "Oito de Chicago", mártires do proletariado na luta pela jornada de oito horas de trabalho.

${ }^{194}$ O caso mais evidente foi o de Arthur Bernardes que realizou boa parte de seu governo sob estado de sítio.
} 
Assim como o realismo jurídico apresentava-se (i) em Yale University e Columbia University, como crítica à escola mecanicista de Langdell (KALMAN, 1986, p.67; LEITER, 2003, p. 3), (ii) na Suprema Corte, como oposição ao laissez-faire, e (iii) no governo Roosevelt, como aparato implementador do New Deal e defensor de um contencioso administrativo, construía-se no Brasil uma forte oposição do pensamento jurídico dos anos 1930 em relação ao pensamento liberal que havia se consolidado na República Velha (1889/1930).

Esquerda e direita estavam de acordo que o modelo liberal havia fracassado. Tanto João Mangabeira, como Oliveira Vianna defenderam a elevação da questão social ao centro do novo Estado. Era necessário redefinir as relações no núcleo da produção capitalista. Era preciso construir um aparato jurídico capaz de regular relações cuja natureza era diferente das relações comerciais e civis. As relações de trabalho não poderiam mais ser reguladas por contratos de locação de serviços. E tanto Mangabeira, como Vianna foram buscar no mercado global de idéias soluções que legitimassem o novo modelo de relação jurídica. Dentre muitos desencontros, ambos buscaram nos votos de Louis Brandeis tanto as críticas ao modelo liberal, como a defesa pelo Welfare State.

Desse modo, a escola realista, enquanto uma teoria do direito, ao vincular o direito aos fins do Estado, permitia uma abertura valorativa tal que dependia da "boa vontade" de quem governasse. Assim, poderia estar a serviço tanto de um governo democrático como o governo norte-americano de Franklin Roosevelt, como poderia instrumentalizar um regime ditatorial/autoritário como o de Getúlio Vargas. Essa parece ser a razão que justifica a utilização dos textos e votos de Louis Brandeis, um jurista de centro-esquerda, por Oliveira Vianna, um jurista de tendências conservadoras.

A questão social não se restringiu ao debate sobre a legislação trabalhista e social. A questão social também estava presente no debate sobre o desenho institucional. $\mathrm{O}$ diagnóstico comum dessa literatura crítica desde as propostas de reforma constitucional de Alberto Torres era a necessidade de uma releitura da concepção clássica de divisão dos poderes. Enquanto nos Estados Unidos da América a tradição cientificista de James Landis disputava espaço com a tradição legalista de Roscoe Pound sobre a divisão de papéis adjudicatórios da Administração e do Judiciário, Oliveira Vianna defendia a ampliação do poder dos tribunais administrativos. Para não falar sobre o debate entre Vianna e 
Waldemar Ferreira sobre a criação da Juntas Trabalhistas. No entanto, essa disputa entre Administração e Judiciário não foi tão determinante no debate jurídico brasileiro como foi nos Estados Unidos, conforme ficou evidente na análise dos textos de Francisco Campos em defesa do contencioso judicial. A razão está no fato de que: (i) no Brasil, o Supremo não havia se consolidado como uma instituição suficientemente sólida para disputar espaço com a Administração e (ii) na atuação de Vargas, que, desde o início do Governo Provisório, neutralizou o Supremo Tribunal Federal com o Decreto de 1931.

No entanto, apesar dessa neutralização do Supremo, alguns de seus ministros foram fundamentais para o debate sobre a elaboração de um novo método de direito público e para a formulação, ainda que tímida, de uma crítica ao conceitualismo que havia se consolidado na República Velha. A própria comissão que elaborou a Lei de Introdução ao Código Civil de 1942 era composta por dois ministros do Supremo, Orozimbo Nonato e Philadelpho Azevedo. Além disso, o principal comentador da lei também era ministro do Supremo, Eduardo Espínola.

Independentemente de qual tenha sido a interpretação posterior da lei, o seu artigo 5. ${ }^{\circ}$ determinava que o juiz deveria, ao aplicar a lei, seguir seu fim social. De acordo com as evidências históricas recolhidas nesta pesquisa, parece que se tratava de uma inserção da questão social na própria interpretação legislativa. Era a influência do regime político na definição do papel do intérprete da lei, descrita por Alípio Silveira. O Decreto-lei de 1942 foi feito no interior da onda temática da questão social e não poderia escapar de sua influência. A Era Vargas deixava seus reflexos em uma área de enorme resistência do liberalismo e do conceitualismo, o direito civil. E, aqui, o diálogo dos autores brasileiros com a jurisprudência sociológica de Roscoe Pound foi determinante para a construção de um debate sobre a interpretação judicial.

Enfim, o pensamento jurídico brasileiro que se formou durante a Era Vargas tinha como principal objetivo encontrar soluções para um Brasil que se via diante de novos desafios. A periferia do capitalismo enfrentava os problemas gerados pelo capitalismo industrial. Dentre os muitos diálogos que se traçaram, os juristas também olharam para o centro da economia mundial e se alimentaram de suas idéias. São os fragmentos perdidos de uma parte da história do direito brasileiro. 


\section{BIBLIOGRAFIA}

ACKERMAN, Bruce. (2006), Nós, o Povo Soberano - Fundamentos do Direito Constitucional, trad. Mauro Raposo de Mello, Belo Horizonte, Del Rey.

AGAMBEN, Giorgio. (1998), Homo Sacer, Lisboa, Presença. (2004), Estado de Exceção, São Paulo, Boitempo.

ALEXANDER, Gregory S.. (2002), "Comparing the two legal realisms - American and Scandinavian", The American Journal of Comparative Law, vol. 50, 2002, pp. 131174.

ALONSO, Angela. (2002), Idéias em Movimento - A geração de 1870 na crise do Brasil-Império, São Paulo/Rio de Janeiro, Paz e Terra.

ALVES, Maria Helena Moreira. (1985), State and Opposition in Military Brazil, Austin, University of Texas Press.

AMARAL, Francisco. (2005), "O Código Civil brasileiro e o Problema metodológico de sua realização. Do paradigma da aplicação ao paradigma judicativodecisório", Revista Brasileira de Direito Comparado, Rio de Janeiro, Instituto de Direito Comparado Luso-Brasileiro.

ANDERSON, Benedict. (1983), Imagined Communities - reflections on the origin and spread of nationalism, New York, Verso.

ANDRADE, Christiano José de. (1991), Hermenêutica Jurídica no Brasil, São Paulo, Editora Revista dos Tribunais.

ARAÚJO, Rosa Maria Barbosa de. (1981), O batismo do trabalho - a experiência de Lindolfo Collor, Rio de Janeiro, Civilização Brasileira.

ARENDT, Hannah. (1989) [1951], Origens do Totalitarismo, Trad. Roberto Raposo, São Paulo, Companhia das Letras. 
(2004) [1959], A condição humana, Trad. Roberto Raposo,

$10^{\mathrm{a} e d}$., Rio de Janeiro, Forense Universitária.

(2005) [1954], Entre o passado e o futuro, Trad. Mauro

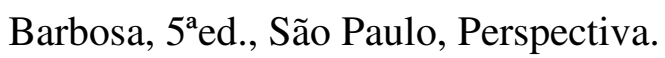

ARRUDA, Hélio Mário de. (2007), Oliveira Vianna e a Legislação do Trabalho no Brasil, São Paulo, LTr.

ASCARELLI, Tullio. (1999), Problemas das sociedades anônimas e direito comparado, Campinas, Bookseller.

ATIENZA, Manuel. (2001), Cuestiones Judiciales, Cidade do México, BÉFDP.

BALEEIRO, Aliomar. (1968), O Supremo Tribunal Federal, êsse outro desconhecido, Rio de Janeiro, Forense.

BAPTISTA, Francisco de Paula. (1910), Compendio de Theoria e Pratica do Processo Civil Comparado com o Comercial e de Hermeneutica Juridica, Lisboa, Livraria Classica Editora de A.M.Teixeira \& C..

BARBALHO, João Uchôa Cavalcanti. (1902), Constituição Federal Brasileira, Rio de Janeiro, Litho-Typographia.

BARBOSA, Francisco de Assis. (1987a), Idéias Políticas de João Mangabeira, Brasília/Rio de Janeiro, Senado Federal/Casa Rui Barbosa, 3v.

. (1987b), Idéias Políticas de João Mangabeira,

Brasília/Rio de Janeiro, Senado Federal/Casa Rui Barbosa, 3v.

. (1987c), Idéias Políticas de João Mangabeira,

Brasília/Rio de Janeiro, Senado Federal/Casa Rui Barbosa, 3v.

BARBOSA, Rui. (1928), Collectaneas Jurídicas - O hábeas corpus. A amnistia. O Supremo no nosso mecanismo político. Cessões de Clientela. As condecorações. A posse de direitos pessoais, Rio de Janeiro, Nacional. 
(1956a) [1890], Obras completas de Rui Barbosa, v. XVII,

Tomo I, Rio de Janeiro, Ministério da Educação e Cultura.

(1956b) [1892], Obras completas de Rui Barbosa, v. XIX, Tomo

III, Rio de Janeiro, Ministério da Educação e Cultura.

(1956c) [1893], Obras completas de Rui Barbosa, v. XX, Tomo

V, Rio de Janeiro, Ministério da Educação e Cultura.

(1960), Escritos e discursos seletos, Rio de Janeiro, J. Aguilar.

BATAlHA, Wilson de Souza Campos. (1957), Lei de Introdução ao Código Civil - Fontes e Interpretação do Direito, vol. 1, São Paulo, Max Limonad.

e BATALHA, Silvia Marina Labate. (1994),

Sindicatos, Sindicalismo, $2^{\mathrm{a}}$. Ed., São Paulo, LTr.

BENDER, Thomas. (2006), A Nation among Nations - America's Place in World History, New York, Hill and Wang.

BERCOVICI, Gilberto. (2003), Instabilidade constitucional e direitos sociais na Era Vargas, In BITTAR, Eduardo C. B., História do Direito Brasileiro, São Paulo, Atlas. (2004), Constituição e Estado de Exceção Permanente, São

Paulo, Azougue.

BILLIER, Jean-Cassien e MARYOLI, Aglaé. (2005), História da Filosofia, Barueri, Manole.

BOSCHETTI, Ivanete. (2006), Seguridade Social e Trabalho - Paradoxos na Construção das Políticas de Previdência e Assistência Social no Brasil, Brasília, Letras Livres/UnB.

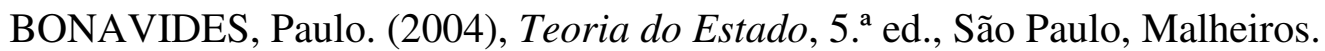

BOSI, Alfredo (1992), “A Arqueologia do Estado Providência”, Dialética da Colonização. $3^{\mathrm{a} e d ., ~ S a ̃ o ~ P a u l o, ~ C o m p a n h i a ~ d a s ~ L e t r a s . ~}$ 
BRANCO, Rodrigo Castelo. (2006), A “Questão social” na origem do capitalismo - pauperismo e luta operária na teoria social de Marx e Engels, Dissertação de mestrado apresentada ao Centro de Filosofia e Ciências Humanas da Universidade Federal do Rio de Janeiro sob a orientação do Professor Carlos Nelson Coutinho, Rio de Janeiro, UFRJ.

BRANDÃO, Gildo Marçal. (2007), Linhagens do Pensamento Político Brasileiro, São Paulo, Aderaldo e Rothschild/Hucitec.

BRASIL, Antonio Silveira Jr. (2007), Uma Sociologia Brasileira da Ação Coletiva - Oliveira Vianna e Evaristo de Moraes Filho, Dissertação de mestrado apresentada ao programa de pós-graduação em sociologia e antropologia do Instituto de Ciências Sociais da Universidade Federal do Rio de Janeiro, sob a orientação da Professora Glaucia Kruse Villas Bôas, Rio de Janeiro, UFRJ.

BRINKLEY, Alan. (2004), The Unfineshed Nation - A concise history of the United States, New York, McGraw Hill.

. (2005), "The Debate over the Constitutional Revolution of 1937”, The American Historical Review, Oct/2007, vol. 110, n. 4.

BRITO, Miguel Nogueira de. (2005), Originalismo e Interpretação Constitucional, In SILVA, Virgílio Afonso da (org.), Interpretação Constitucional, São Paulo, Malheiros.

BROWN, R. Blake e KIMBALL, Bruce A. (2001), "When Holmes borrowed from Langedell - The 'ultra-legal' formalism and public policy of nothern security (1904)", American Journal of Legal History, $\mathrm{n}^{\circ}$ 45, 2001.

CAMPOS, Francisco. (1956), Direito Constitucional, São Paulo, Freitas Bastos, $2 \mathrm{v}$. . (1943), Direito Administrativo, Imprensa Nacional, Rio de Janeiro.

CAPPELLETTI, Mauro. (2001), O processo civil no direito comparado, trad. Hiltomar Martins, Belo Horizonte, Cultura Jurídica/Líder, 2001. 
CARDOZO, Benjamin Nathan. (1991), The nature of the judicial process, New Haven/London, Yale University Press.

(2004), A natureza do processo judicial, trad.

Silvana Vieira e Álvaro de Vita, São Paulo, Martins Fontes.

CARONE, Edgar. (1978), A Segunda República (1930-1937), 3ª Ed., Rio de Janeiro, Difel.

CARRIDE, Norberto de Almeida. (2004), Lei de Introdução ao Código Civil Anotada, São Paulo, Juarez de Oliveira.

CARVALHO, José Murilo de. (2007), Cidadania no Brasil - o longo caminho, $9^{\mathrm{a}}$. Ed., Rio de Janeiro, Civilização brasileira.

- (2003), A Construção da Ordem: a elite política imperial. Teatro de Sombras: a política imperial, Rio de Janeiro, Civilização Brasileira.

(org.) (2002), Visconde do Uruguai, São Paulo, Editora

34. (1999), Pontos e bordados - escritos de história e política, Belo Horizonte, Editora UFMG. (1990), A formação das almas - o imaginário da República do Brasil, São Paulo, Companhia das Letras. (1987), Os Bestializados - o Rio de Janeiro e a República que não foi, São Paulo, Companhia das Letras.

CASALINI, Brunella. (2006), Soberania popular, governo da lei e governo dos juízes nos Estados Unidos da América, in COSTA, Pietro e ZOLO, Danilo (org.). (2006), O Estado de Direito - História, teoria, crítica, trad. Carlos Alberto Dastoli, São Paulo, Martins Fontes.

CASTEL, Robert. (1998), As metamorfoses da questão social - uma crônica do salário, $4^{\mathrm{a}}$. Ed., Petrópolis, Vozes. 
CASTRO, Augusto Olympio Viveiros de. (1920), A questão social, Rio de Janeiro, Editora Conselheiro Cândido de Oliveira S.A.

CAVALCANTI, Themistocles Brandão. (1957), Do mandado de segurança, $4^{\mathrm{a}} \mathrm{ed}$. São Paulo, Freitas Bastos.

CEREJA, William Roberto e MAGALHÃES, Thereza Cochar. (1995), Literatura Brasileira, São Paulo, Atual.

CESARINO, A. F. Jr. (1970), Direito social brasileiro, São Paulo, Saraiva.

CHACON, Vamireh. (1985), História dos Partidos Brasileiros - discurso e práxis dos seus programas, $2^{\mathrm{a}}$ ed., Brasília, UnB.

COELHO, Inocêncio Mártires. (2003), Interpretação Constitucional, 3. a ed., Porto Alegre, Fabris.

COHEN, Morris. (1927), "Property and Sovereignty”, Cornell L. Q., 13 (1927), 830.

COHN, Amélia. (2000), A questão social no Brasil: a difícil construção da cidadania, in MOTA, Carlos Guilherme (org.), Viagem Incompleta - A grande transição, $2^{a}$. Ed., São Paulo, Senac.

COLLOR, Lindolfo. Org. Mário de Almeida Lima (1991), Origens da Legislação Trabalhista Brasileira, Porto Alegre, Fundação Paulo do Couto e Silva.

CORWIN, Edward S.. (1932), "Social planning under the Constitution - A study in perspectives", American Political Science Review, vol. 28.

- (1986), A Constituição Norte-americana e seu significado atual, trad. Lêda Boechat Rodrigues Rio de Janeiro, Jorge Zahar.

COSTA, Edgard. (1964), Os grandes julgamentos do Supremo Tribunal Federal1929-1948, v. 2, Rio de Janeiro, Civilização Brasileira.

COSTA, Emília Viotti da Costa. (2006), O Supremo Tribunal Federal e a construção da cidadania, $2^{\mathrm{a}}$ ed., São Paulo, UNESP. 
Histories, Chicago, University of Chicago Press.

COSTA, Pietro e ZOLO, Danilo (org.). (2006), O Estado de Direito - História, teoria, crítica, trad. Carlos Alberto Dastoli, São Paulo, Martins Fontes.

DANTAS, San Tiago. (1962), Figuras do Direito, Rio de Janeiro, José Olympio.

DEWEY, John. (2004 - 1920), Reconstruction in Philosophy, Mineola, Dover. . (2002 - 1922), Human Nature and Conduct, Mineola, Dover. (1970), Liberalismo, Liberdade e Cultura, títulos originais: Liberalism and Social Action (1935) e Freedom and Culture (1939), Trad. Anísio Teixeira, São Paulo, Editora Nacional/EDUSP.

DICEY, A.V. (1965), Introduction to the study of the law of the constitution, $10 .^{\mathrm{a}}$ ed. London, Macmillan.

DULLES, John W. F.. (1985), O Comunismo no Brasil - 1935-1945 - Repressão em meio ao cataclismo mundial, trad. Raul de Sá Barbosa, Rio de Janeiro, Nova Fronteira.

DUXBURY, Neil. (1995), Patterns of American Jurisprudence, Oxford, Clarendon Press.

ECO, Umberto. (2007), "O cuidado com os nomes", Entre Livros, n. 32, dezembro/2007, São Paulo, Duetto.

ELLUL, Jacques. (1993), Histoire des Institutions, Vol. 5, 12 ${ }^{\mathrm{a}}$ ed., Paris, Presses Universitaires de France.

ELSTER, Jon. (1994), Peças e Engrenagens das ciências sociais, Tradução de Antônio Trânsito, Rio de Janeiro, Relume-Dumará.

ENGELS, Friedrich. (1981) [1844], Esboço de uma crítica da economia política, Friedrich Engels - política, José Paulo Netto (org.)/Florestan Fernandes (coord.), São Paulo, Ática. 
ESPÍNOLA, Eduardo e ESPÍNOLA, Eduardo Filho. (1940), “O Método positivo na interpretação e na integração das normas jurídicas - com prévia exposição do direito livre e dos métodos ecléticos sugeridos", Tratado de Direito Civil Brasileiro, vol. IV, Rio de Janeiro/São Paulo, Freitas Bastos.

FAORO, Raymundo. (2001), Os donos do poder - Formação do patronato político brasileiro, $3^{\mathrm{a}}$. Ed., São Paulo, Globo.

FARIA, José Eduardo Campos de Oliveira. (1978), Poder e Legitimidade. São Paulo, Perspectiva.

(2002), Qual o futuro dos direitos?

Estado, mercado e justiça na reestruturação capitalista, São Paulo, Max Limonad.

(1999), A Cultura e as Profissões

Jurídicas, In NALINI, José Renato (org.), Formação Jurídica, São Paulo, RT.

FAUSTO, Boris. (2001), O pensamento nacionalista autoritário, Rio de Janeiro, Jorge Zahar.

FERRARA, Francesco. (1978), Interpretação e Aplicação das Leis, trad. Manuel A. Domingues de Andrade, $3^{\mathrm{a}}$ ed., Coimbra, Armênio Amado.

FERRAZ Jr., Tércio Sampaio. (1994), O Judiciário frente à divisão dos poderes: um princípio em decadência?, In Revista USP n 21: Dossiê Judiciário. São Paulo, USP, pp. 12-21.

FERREIRA, Francisco José Calheiros Ribeiro. (1993), Juiz classista no poder judiciário - uma forma de participação popular na administração da justiça, São Paulo, dissertação de mestrado apresentada à Faculdade de Direito da Universidade de São Paulo.

FERREIRA, Waldemar. (1983) (1939), Princípios de legislação social e direito judiciário do trabalho, São Paulo.

FISHER III, William W.. (1996-1997), “Interpreting Holmes”, Harvard Law Review, v. 110, 1997, pp. 1010-1012. 
(1996-1997), “Texts and Contexts: The Application to American Legal History of Methodologies of Intelectual History”, Stanford Law Review, vol. 49, 1997, pp. 1065-1110.

FISS, Owen. (2004), Um novo processo civil - estudos norte-americanos sobre jurisdição, constituição e sociedade, Trad. Carlos Alberto de Salles, São Paulo, Revista dos Tribunais.

FRANCISCO, Caramuru Afonso. (2005), Lei de Introdução ao Código Civil, São Paulo, Juarez de Oliveira.

FRANCO, Afonso Arinos de Melo. (1960), Curso de Direito Constitucional Brasileiro, Rio de Janeiro, Forense.

FREUND, Paul A.. (1979), "Foreword: Homage to Mr. Justice Cardozo", Cardozo Law Review, vol. 1, 1979, pp. 1-4.

FRENCH, John. (1991), "The Origin of Corporatist State Intervention in Brazilian Industrial Relations, 1930-1934: A Critique of the Literature", Luso-Brazilian Review, vol. 28, N. 2, Winter/1991, pp. 13-26.

GALBRAITH, John Kenneth. (1982), O Novo Estado Industrial, trad. Leônidas Gontijo de Carvalho, $3^{\mathrm{a}}$ ed., São Paulo, Abril Cultural.

GARTH, Brian e STERLING, Joyce. (1998), "From Legal realism to Law and Society - Reshaping law for the last stages of the social activist State", Law \& Society Review, vol. 32, n. ${ }^{\circ}$ 2, 1998, pp. 409-472.

GIACOMUZZI, José Guilherme. (2005), “As Raízes do Realismo Americano breve esboço acerca de dicotomias, ideologia, e pureza no Direito dos USA”, Direito $e$ Justiça, ano XXVII, vol. 31, n. 2, pp. 155-190.

GILISSEN, J. (1988) Introdução Histórica ao Direito. Lisboa, Calouste Goulbenkian.

GILMORE, Grant. (1977), The ages of American Law, New Haven/London, Yale University Press. 
GOMES, Ângela Maria de Castro et al. (2007a), Sindicalismo e classe operária (1930-1964) - Capítulo X, In História Geral da Civilização Brasileira, Tomo III - O Brasil Republicano, vol. 10 - Sociedade e Política (1930-1964), Rio de Janeiro, Bertrand Brasil.

. (2007b) Autoritarismo e corporatvismo no

Brasil - intelectuais e construção do mito Vargas, In MARTINHO, Francisco Carlos Palomanes e PINTO, António Costa, O Corporativismo em português - Estado, política e sociedade no salazarismo e no varguismo, Rio de Janeiro, Civilização brasileira. (1993), A práxis corporativa de Oliveira Vianna, In BASTOS, Elide Rugai e MORAES, João Quartim de (org.), O pensamento de Oliveira Vianna, Campinas, Unicamp.

(1979), Burguesia e trabalho: política e legislação social no Brasil (1917-1937), Rio de Janeiro, Ed. Campus.

GOMES, Orlando. (2006), Raízes históricas e sociológicas do Código Civil brasileiro, $2^{\mathrm{a}}$. Ed., São Paulo, Martins Fontes.

e GOTTSHALK, Elson. (1963), Curso de Direito do Trabalho, Rio de Janeiro/São Paulo, Forense, 2v.

GORDLEY, James. (1991), The Philosophical Origins of Modern Contract Doctrine, Oxford, Oxford University.

GORDON, Robert W..(1997), “The Path of the Lawyer", Harvard Law Review, vol. 110, pp. 1013-1018.

GREENAWALT, Kent. (2000), "Variations on some themes of a 'disporting gazelle' and his friend: Statutory interpretation as seen by Jerome Frank and Felix Frankfurter", Columbia Law Review, vol. 100, 2000, pp. 177-214.

(1997), "Interpretation and Judgement", Yale Journal of Law and the Humanities, vol. 9, 1997, pp. 415-436. 
GREY, Thomas C. (1995), "Molecular Motions - The holmesian judge in theory and practice", Wm. \& Mary Law Review, n³7, 1995.

GROSSI, Paolo. (2004), Mitologias jurídicas da modernidade, Florianópolis, Fundação Boiteux.

GURVICH, Georges. (1932), Le temps present et l'idée du Droit Social, Paris, Librarie Philosophique J. Vri.

HALL, Kermit L. (1989), The Magic Mirror - Law in America History, New York/Oxforf, Oxford University Press.

HAMILTON, Alexander, MADISON, James, JAY, John. (1984), O Federalista. Brasília, UnB.

HART, Hebert L. A.. (1994), O Conceito do Direito, trad. A. Ribeiro Mendes, Lisboa, Calouste Gulbenkian.

HEKMAN, Susan J. (1986), Hermenêutica e Sociologia do Conhecimento, trad. Luis Manuel Bernardo, Lisboa, Edições 70.

HESPANHA, Antônio M. (1982), História das Instituições - Épocas Medieval e moderna, Coimbra, Almedina.

(1994), As Vésperas do Leviatã. Coimbra,

Almedina.

(1998), Panorama Histórico da Cultura Jurídica Européia, $2^{\mathrm{a}}$ ed., Lisboa, Forum da História.

(2003), Pequenas repúblicas, grandes Estados.

Problemas de organização política entre antigo regime e liberalismo, In István Jancsó (org.), Brasil: Formação do Estado e da Nação, São Paulo, Unijui, Hucitec, Fapesp, pp. 93-108. 
HIRSCHL, Ran. (2005), "The question of case selection in comparative constitutional law", The American Journal of Comparative Law, vol. 53, 2005, pp. 125156.

HOLMES, Oliver Wendell Jr. ([1881] 2004), The Common Law, New York, Barnes and Nobel. . (1897), "The path of the Law", Harvard Law Review, v. 10, 1897, pp. 457-478.

HOPKINS, James D.. (1883-1884), "The development of Realism in law and literature during the period 1833-1933: the cultural resemblance", Pace Law Review, vol. 4, 1983, pp. 29-60.

HORWITZ, Morton J. (1998), The Warren Court and the Pursuit of Justice, New York, Hill and Wang. (1992), The transformation of American Law - The Crisis of Legal Orthodoxy 1870-1960, New York, Oxford University Press. , FISHER III, William W., REED, Thomas A. (1993), American Legal Realism, New York, Oxford University Press. (1978), “Ages of American Law”, Buffalo Law Review, $\mathrm{n}^{\circ}$ 27, 1978.

HULL, N. E.H. (1990), "Restatement and Reform: A New Perspective on the Originsof the American Law Institute", Law and History Review, vol. 8, 1990.

IRONS, Peter. (1999), A peoples history of Supreme Court, New York, Penguin Books.

JAMES, William. (1967), Pragmatismo e outros ensaios, trad. Jorge Caetano da Silva, Rio de Janeiro, Lidador.

JOHNSON, Paul. (1999), A History of the American People, New York, Harper. 
KALMAN, Laura. (2005), Yale Law School and the Sixties - revolt and reverberations, North Carolina, The University of North Carolina Press.

. (2000), “Does character affect judicial performance?", University of Colorado Law Review, vol. 71, 2000, pp. 1385-1420.

. (1998-1999), "Law, politics and the New Deal (s)", The Yale Law Journal, vol. 108, 1999, pp. 2165-2214.

. (1997-1998), "Border Patrol: Reflections on the turn to history in legal scholarship", Fordham Law Review, vol. 66, 1997, pp. 87-124.

. (1996-1997), "Eating spaghetti with a spoon”, Stanford Law Review, vol. 49, 1996, pp. 1547-1582.

. (1995), “To hell with Langdell”, Law and Social Inquiry, vol. 20, 1995, pp. 771-776.

. (1986), Legal Realism at Yale, North Carolina, The University of North Carolina Press.

KAREPOVS, Dainis. (2006), A classe operária vai ao parlamento - o bloco operário e camponês do Brasil (1924-1930), São Paulo, Alameda.

KAUFMAM, Andrew L. (1979), “Cardozo's appointment to the Supreme Court”, Cardozo Law Review, vol. 1:23, 1979, pp. 23-54.

KEYNES, John Maynard. (1936), The General Theory of Employment, Interest and Money, New York, Harcourt.

KOERNER, Andrei. (1998), Judiciário e Cidadania na Constituição da República brasileira, São Paulo, USP, Departamento de Ciência Política.

(1999), Habeas-Corpus e Controle Social no Brasil (18411920), São Paulo, IBCCrim. 
KOSELLECK, Reinhart. (2006), Futuro Passado - Contribuição à semântica dos tempos históricos, trad. Wilma Patricia Maas e Carlos Almeida Pereira, Rio de Janeiro, PUC-Rio.

KUNTZ, Rolf. (2002), Alberto Torres - A Organização Nacional, in MOTA, Lourenço Dantas (org.), Introdução ao Brasil - Um Banquete no Trópico, São Paulo, Senac.

LAMONIER, Bolívar. (2006), Formação de um pensamento político autoritário na Primeira República. Uma interpretação, in PINHEIRO, Paulo Sérgio et al. História Geral da Civilização Brasileira, Tomo III - O Brasil Republicano, Vol. 9 - Sociedade e Instituições (1889-1930), $8^{\mathrm{a}}$ ed., Rio de Janeiro, Bertrand Brasil.

LANGDELL, Christopher Columbus. (1880), A Summary of the Law of Contracts, Boston, Little Brown and Company.

LASKI, Harold J.. (1930-1931), “The Political Philosophy of Mr. Justice Holmes”, Yale Law Journal, vol. XL, n. ${ }^{\circ}$ 5, 1931, pp. 683-695.

LASSER, Mitchel. (2002), "Comparative Readings of Roscoe Pound's Jurisprudence", The American Journal of Comparative Law, vol. 50, 2002, pp. 719-752.

LEAL, Vitor Nunes. (1975), Coronelismo, enxada e voto. $2^{\mathrm{a} e d ., ~ S a ̃ o ~ P a u l o, ~ A l f a-~}$ Omega.

(1964), "Palestra sobre a Súmula Vinculante", Revista Forense, n. ${ }^{\circ} 208$, out-dez., pp. 15-18.

LEITER, Brian. (2003), American Legal Realism, in EDMUNDSON, W.; GOLDING, M (ed.). The Blackwell Guide to Philosophy of Law and Legal Theory, Oxford, Blackwell.

LERNER, Max. (1931), "The social thought of Mr. Justice Brandeis", Yale Law Journal, vol. XLI, 1931, pp. 1-32. (1932-1933), “The Supreme Court and American capitalism”, Yale Law Journal, vol. 42, 1933, pp. 668-701. 
LESSA, Pedro Augusto Carneiro. (1915), O Poder Judiciário. Rio de Janeiro, Francisco Alves.

"O Direito no Século XIX”, Revista do Instituto

Histórico, vol. LXVIII.

LEUCHTENBURG, William E. (1963), Frankiln D. Roosevelt and the New Deal, New York, Harper \& Row.

LEVINE, Robert M. (2002), Pai dos Pobres? O Brasil e a Era Vargas, São Paulo, Companhia das Letras.

LIMA, Ângela Maria de Sousa. (2003), "Uma reflexão sobre Oliveira Vianna, sua culturologia do Estado", http://www.fanorpi.com.br/web/atividades/artigos.

LIMA, A. Sabóia. (1935), Alberto Torres e a sua obra, São Paulo, Companhia Editora Nacional.

LIMA, Heitor Ferreira. (1976), História Político-Econômica e Industrial do Brasil, Coleção brasiliana, vol. 347, São Paulo, Companhia Editora Nacional.

LIMA, Hermes. (1987), Introdução, in BARBOSA, Francisco de, Idéias Políticas de João Mangabeira, Brasília/Rio de Janeiro, Senado Federal/Casa Rui Barbosa.

LIMONGE, Dante Braz. (1998), O Projeto Político de Pontes de Miranda - Estado e Democracia na Obra de Pontes de Miranda, Rio de Janeiro, Renovar.

LLEWELlYN, Karl N. (1935), "Holmes”, Columbia Law Review, vol. XXXV, Abril, $\mathrm{n}^{\circ} 4,1935$.

. (1931). "Some realism about realism - responding to Dean Pound", Harvard Law Review, v. 44, 1931, pp. 1222-1256.

. (1930-1931), "What a price contract? - An essay in perspective", Yale Law Journal, vol. 40, 1931, pp. 704-751. 
(1930), "A realistic jurisprudence - the next step", Columbia Law Review, v. 431, ano 30, pp. 432-465.

LOPES, José Reinaldo de Lima. (1994), "Justiça e Poder Judiciário", Revista USP, $n^{\circ} 21$, Dossiê Judiciário, São Paulo, USP, pp. 22-33.

(1997), Direito e Transformação Social - ensaio interdisciplinar das mudanças no Direito, Belo Horizonte, Nova Alvorada.

(2002a), O Direito na História - Lições Introdutórias, $2^{\text {a }}$ ed., São Paulo, Max Limonad.

(2002b), "Processo e Justiça (Social, Distributiva, Política)", Revista dos Procuradores da República, Ano V - nº 55 - novembro, pp. 12-19

(2003), Iluminismo e jusnaturalismo no ideário dos juristas da primeira metade do século XIX, In JANCSÓ, István (org.), Brasil - Formação do Estado e da Nação, São Paulo, Unijui, Hucitec, Fapesp, pp.195-218.

(2004), As Palavras e a Lei - Direito, ordem e justiça na história do pensamento jurídico moderno, São Paulo, Editora 34.

(2005), Régua e Compasso - ou Metodologia para um trabalho jurídico sensato, São Paulo, cópia traduzida do autor do texto Reglás y compás, In COURTS, Christian (org). (2006), Observar la ley, Madrid, Editorial Trotta, v. 1. (2006), Direitos Sociais - Teoria e prática, São Paulo, Método.

LUCCA, Tânia Regina de. (2001), Indústria e Trabalho no Brasil, São Paulo, Contexto.

MACCORMICK, Neil. (2006), Argumentação jurídica e teoria do direito, São Paulo, Martins Fontes.

(1981). H. L. Hart, Stanford, Stanford Univ. Press.

MACEDO, Ronaldo Porto. (1998), Contratos Relacionais e Defesa do Consumidor, São Paulo, Max Limonad. 
MALTA, Octavio. (1969), Os Tenentes na Revolução Brasileira, Rio de Janeiro, Civilização Brasileira.

MANGABEIRA, João. (1934), Em torno da Constituição, Companhia Editora Nacional, São Paulo.

MANNHEIM, Karl. (1976), Ideologia e Utopia, trad. Sérgio Magalhães Santeiro, 3. ${ }^{\text {a }}$ ed., Rio de Janeiro, Zahar.

. (1962), O Homem e a Sociedade, trad. Waltensir Dutra, Rio de Janeiro, Zahar, 301.24 M282h e.4.

MANOILESCO, Mihail. (1938), O Século do Corporativismo - Doutrina do corporativismo integral e puro, trad. Azevedo Amaral, Livraria J., Rio de Janeiro.

MARX, Karl e ENGELS, Friedrich. (1998) [1844], Manifesto Comunista, São Paulo, Boitempo.

MARTINS, Ana Lúcia Nina Bernardes. (2002), "Florida Vote”: Direito e Política na perspectiva do "Legal Realism", In VIEIRA, José Ribas (org.), Temas de Direito Constitucional Norte-americano, Rio de Janeiro, Forense.

MARTINS, Wilson. (1978), História da Inteligência Brasileira (1915-1933), vol. IV, São Paulo, Cultrix/EDUSP.

MAUK, David e OAKLAND, John. (2005), American Civilization - An Introduction, $4^{\mathrm{a}}$. Ed., New York, Rouldge.

MAXIMILIANO, Carlos. (1925), Hermeneutica e Applicação do Direito, Porto Alegre, Barcellos, Bertaso e Cia.

MEDINA, Diego Eduardo López. (2004), Teoria impura del derecho - La transformación de la cultura jurídica latinoamericana, Bogotá, Legis.

MELLO, Augusto Cordeiro de. (1964), O processo no Supremo Tribunal Federal, Rio de Janeiro, Freitas Bastos. 
MERICLE, Kenneth S. (1977), Corporatist Control of the Working class Authoritarian Brazil since 1964, in MALLOY, James M., Authoritarianism and Corporatism in Latin America, Pittsburgh, University of Pittsburgh Press.

MIRANDA, Francisco Cavalcanti Pontes de. (1972), Sistema de Ciência Positiva do Direito, Rio de Janeiro, Borsoi. - (1938), "Visão Sociológica da Constituição de 1937”, Revista Forense, vol. LXXIV, Ano XXXV, fascículo 418, junho de 1938, Rio de Janeiro, Forense, pp. 19-22.

. (1932), Fundamentos Atuais do

Direito Constitucional, Rio de Janeiro, Freitas Bastos.

MORAIS FILHO, Evaristo de. (1956), Introdução ao Direito do Trabalho, vols. 1 e 2, Rio de Janeiro, Forense.

MORRIS, Clarence (org.). (2002), Os Grandes Filósofos do Direito, trad. Reinaldo Guarany, São Paulo, Martins Fontes.

MORTARI, Vincenzo Piano. (1976), Dogmática e Interpretazione - I Giuristi Medievali, Napoli, Jovene.

MOURÃO, Carvalho. (1936), "Voto da decisão do agravo de petição n. 6.374 de 19 de junho de 1935", Revista Arquivo Judiciário.

NIEMEYER, W. (1936), Curso de Legislação Brasileira do Trabalho, Rio de Janeiro, A. Coelho Branco Filho.

NÓBREGA, Flavianne Fernanda Bitencourt. (2006), "Por uma metodologia do direito de base pragmatista - o raciocínio abdutivo do direito", Anais do XV CONPEDI, Manaus, CONPEDI.

NONATO, Orosimbo, AZEVEDO, Philadelpho e GUIMARÃES, Hahnemann. (1941), Exposição de Motivos do Anteprojeto de Código das Obrigações (1941), in RANGEL, Leyla Castello Branco (org.). (1989), Código Civil - Anteprojetos, Brasília, Senado Federal. 
NUNES, Castro. (1937), "Da justiça do trabalho no mecanismo jurisdicional do regime", Revista Arquivo Judiciário, vol. 41.

O’DONNELL, Guillermo. (1991), “Democracia Delegativa?”, Novos Estudos CEBRAP, n. ${ }^{\circ} 31$, out/91.

e SCHMITTER, Philippe. (1988), Transições do Regime Autoritário - primeiras conclusões, trad. Adail U. Sobral, São Paulo, Vértice.

(1987), Reflexões sobre os estados burocráticoautoritários, trad. Cláudia Schilling, São Paulo, RT.

(1986), Contrapontos - autoritarismo $e$

democratização, São Paulo, Vértice.

OAKESHOTT, Michael. (2003), Sobre a História e outros Ensaios, Rio de Janeiro, Topbooks.

ODÁLIA, Nilo (1997), As formas do mesmo - Ensaios sobre o pensamento historiográfico de Varnhagen e Oliveira Vianna, São Paulo, UNESP. (2002), A Economia e o pensamento historiográfico de Oliveira Vianna, In SZMRECSÁNYL, Tamás e LAPA, José Roberto do Amaral (org.), História Econômica da Primeira República, São Paulo, EDUSP.

OLIVEIRA, Maria Lúcia de Paula. (1995), Oliveira Vianna e o Direito - Oliveira Vianna, Sua invocação do Realismo Jurídico americano e sua contribuição para a edificação do poder normativo da Justiça do Trabalho: atualidade face à Constituição de 1988, Dissertação de mestrado defendida no Departamento de Ciências Jurídicas da Pontifícia Universidade Católica do Rio de Janeiro, Rio de Janeiro, PUC.

OSÓRIO, Joaquim Luis. (1981), Constituição Política do Estado do Rio Grande do Sul: comentários. Brasília, UnB/Câmara dos Deputados.

PAULA, Felipe de. (2006), Direito e Política - a Decisão Judicial sob a Ótica de Duncan Kennedy, prelo. 
PINHEIRO, Paulo Sérgio de M.S..(1975), Política e Trabalho no Brasil - dos anos vinte a 1930, Rio de Janeiro, Paz e Terra.

PINTO, António Costa. (2007), Estado Novo português e a vaga autoritária dos anos 1930 do século XX, in MARTINHO, Francisco Carlos Palomanes e PINTO, António Costa, O Corporativismo em português - Estado, política e sociedade no salazarismo e no varguismo, Rio de Janeiro, Civilização brasileira.

PIVA, Luiz Guilherme. (2000), Ladrilhadores e semeadores - A modernização brasileira no pensamento político de Oliveira Vianna, Sérgio Buarque de Holanda, Azevedo Amaral e Nestor Duarte (1920-1940), São Paulo, Editora 34.

POLENBERG, Richard. (1997), The World of Benjamin Cardozo - Personal Values and the Judicial Process, Cambridge/ London, Harvard University.

POSNER, Richard A. (1993), Cardozo - A study in reputation, Chicago/London, The University of Chicago Press.

POUND, Roscoe. (1976), Justiça conforme a lei, Rio de Janeiro, Ibrasa. (1931), "The call for a realist jurisprudence", Harvard Law Review, v. 44, 1931, pp. 697-711. . (1909), "Liberty of contract", The Yale Law Journal, v. 18, 1909, pp. 454-470. . (1910), "Law in books and Law in action", American Law Review, v. 44. 1910, pp. 15-36. . (2002), Minha Filosofia do Direito, In MORRIS, Clarence (org.), Os Grandes Filósofos do Direito, trad. Reinaldo Guarany, São Paulo, Martins Fontes.

PRADO, Caio Júnior. (1979), História Econômica do Brasil, 12 a ed., São Paulo, Brasiliense. 
PURCELL, Edward A. Jr. (2003), Caseload burdens and jurisdictional limitations: some observations from the history of the federal courts, New York Law School Law Review, vol. 46, 2002, pp. 7-28.

. (2000), Brandeis and the Progressive Constitution, New Haven/London, Yale University Press.

(1999), "Reconsidering the Frankfurterian Paradigm:

reflections on histories of lower federal courts", Law and Social Inquiry, vol. 24, 1999, pp. 679-750.

. (1994), "Rethinking constitutional change", Virginia Law Review, vol. 80, pp. 279-290.

(1988), American Jurisprudence between the Wars - Legal Realism and the Crises of Democratic Theory, in FRIEDMAN, Lawrence M. e SCHEIBER, Harry N. (coord.), American Law and the Constitutional Order - Historical Perspectives, Cambridge, Harvard University Press.

. (1976), "Alexander M. Bickel and the Post-realist Constitution", Harvard Civil Rights Civil Liberties Law Review, v. 11, 1976, pp. 521-564.

PURDY, Sean. (2007), O Século Americano, in KARNAL, Leandro (et al.), História dos Estados Unidos - das origens ao século XXI, $2^{\mathrm{a}}$ ed., São Paulo, Contexto.

RAUH Jr., Joseph L.. (1979), “A personal view of Justice Benjamin Cardozo: recollections of four Cardozo law clerks", Cardozo Law Review, vol. 1, 1979, pp. 5-22.

ROCHA, Jean Paul Veiga da (2004). "Estudo de Casos", A Capacidade Normativa de conjuntura no Direito Econômico - O Déficit Democrático da Regulação Financeira, São Paulo, Tese de doutorado do Departamento de Direito Econômico e Financeiro da Universidade de São Paulo.

RODRIGES, Leda Boechat. (2002), História do Supremo Tribunal Federal - 19301963. Rio de Janeiro, Civilização Brasileira, v.4. 
Americano, $2^{\text {a }}$. Ed., Rio de Janeiro, Civilização Brasileira. (1991), História do Supremo Tribunal Federal. Rio de Janeiro, Civilização Brasileira, v.1.

RODRIGUES, José Honório. (1978), O Conselho de Estado: o quinto poder?, Senado Federal, Editora do Senado.

ROSANVALLON, Pierre. (1998), A nova questão social, Brasília, Instituto Teotônio Vilela.

ROSS, Alf. (2003), Direito e Justiça, trad. Edson Bini, São Paulo, Edipro.

SÁ, Francisco Filho. (1959), Relações entre os Poderes do Estado, Rio de Janeiro, Borsoi.

, MACHADO, J.G. Neto e SOUZA, J. Ferreira de. (1942), Pareceres de 1940, Rio de Janeiro, Imprensa Nacional.

SALDANHA, Nelson. (2003), Ordem e Hermenêutica, 2. ${ }^{\text {a }}$ ed., Rio de Janeiro/ São Paulo, Renovar.

SANTORO, Emílio. (2006), Rule of law e 'liberdade dos ingleses'. A interpretação de Albert Venn Dicey, in COSTA, Pietro e ZOLO, Danilo (org.). (2006), O Estado de Direito - História, teoria, crítica, trad. Carlos Alberto Dastoli, São Paulo, Martins Fontes.

SANTOS, Wanderley Guilherme dos. (1999), Paradoxos do liberalismo - Teoria e história, $3^{\mathrm{a}}$. Ed., Rio de Janeiro, Revan.

- (1978), Ordem burguesa e liberalismo

político, São Paulo, Duas Cidades.

SCHLESINGER, Arthur M. Jr.. (2003), The Coming of The New Deal (18331835), Coleção The Age of Roosevelt - vol. II, Boston/New York, Mariner. 
SCHWARTZ, Bernard. (1966), Direito Constitucional Americano, trad. Carlos Nayfeld, Rio de Janeiro, Forense. Obra original: (1955), American Constitutional Law, Londres, Cambridge University Press.

SILVA, Hélio. (1969), “1934 - A Constituinte”, In O ciclo de Vargas, Rio de Janeiro, Civilização Brasileira, v.7. (1969a), 1935 - A Revolta Vermelha, Rio de Janeiro, Civilização Brasileira.

SILVA, José Afonso da. (1990), Curso de Direito Constitucional Positivo, São Paulo, Editora Revista dos Tribunais.

SILVA, Francisco Carlos Teixeira da. (2007), Os tribunais da ditadura - o estabelecimento da legislação de segurança nacional no Estado Novo, in MARTINHO, Francisco Carlos Palomanes e PINTO, António Costa, O Corporativismo em português Estado, política e sociedade no salazarismo e no varguismo, Rio de Janeiro, Civilização brasileira.

SILVA, Virgílio Afonso da. (org.). (2005), Interpretação Constitucional, São Paulo, Malheiros.

(2006), "Interpretação conforme a constituição: entre a trivialidade e a centralização judicial", Revista Direito GV, v. 2, n. ${ }^{\circ} 1$, jan-jun/2006, São Paulo, FGV.

SILVEIRA, Alípio. (1946), O Fator Político-social na Interpretação das Leis, São Paulo, Tipografia Paulista.

SIMÃO, Azis. (1981), Sindicato e Estado - suas relações na formação do proletariado de São Paulo, São Paulo, Ática, 320.9816 s588s.

SKIDMORE, Thomas E.. (1975), Brasil - de Getúlio Vargas a Castelo Branco (1930-1964), trad. Ismênia Tunes Dantas, Rio de Janeiro, Paz e Terra.

SMITH, Richard J.. (1929-1930), "The Judicial Interpretation of public utility franchises”, Yale Law Journal, vol. 39, 1930, pp. 957-979. 
SOUSA, Maria do Carmo Campello de (1976), Estado e Partidos Políticos no Brasil - 1930 a 1964, São Paulo, Alfa-Omega.

SOUZA, Letícia Godinho de. (2007), “As origens da discussão do componente social da democracia brasileira - a querela entre Rui Barbosa e Oliveira Vianna", Estudos de Sociologia, Araraquara, vol. 12, n. 22, pp. 117-136.

SOUZA, Daniel Coelho de. (1946), Interpretação e Democracia, Belém, Dissertação para o concurso da cadeira de Introdução à Ciência do Direito da Faculdade de Direito do Pará.

SOUZA NETO, Francisco de Andrade. (1938), Da Justiça do Trabalho e sua Organização e Competência, São Paulo, Livraria Acadêmica Saraiva e Cia. Editores.

STRECK, Lênio Luís. (2002), Jurisdição Constitucional e Hermenêutica, Porto Alegre, Livraria do Advogado.

(1999), Hermenêutica Jurídica e(m) - Uma exploração hermenêutica da construção do Direito, Porto Alegre, Livraria do Advogado.

TEIXEIRA, J. H. Meirelles (org. Maria Garcia). (1991), Curso de Direito Constitucional, Rio de Janeiro, Forense Universitária.

TEIXEIRA, João Paulo Allain. (1997), "Idealismo e realismo constitucional em Oliveira Vianna - análise e perspectiva", Revista de Informação Legislativa, a. 34, n. 135, jul/set, Brasília, Senado.

TOCQUEVILLE, Alexi de. (1850), De la Démocratie en Amérique, Paris, Pagnere.

TORRES, Alberto. (1914), A Organização Nacional. Rio de Janeiro, Imprensa Nacional.

. (1938), O Problema Nacional Brasileiro, $3^{\mathrm{a}}$. Ed., São Paulo, Companhia Editora Nacional.

TRIBE, Laurence e DORF, Michael. (2006), Hermenêutica Constitucional, Brasília, Del Rey. 
TRIBE, Laurence. (1978), American Constitutional Law, Mineola, Foundation.

TRUBECK, David M., DEZALAY, Ives e outros. (1993), Global restruturing and the law - the internationalization of legal fields and creation of transnational arenas, Madison, University of Wisconsin Law School.

TWINING, William. (2007), Globalisation and Comparative Law, in ORÜCÜ, Esin e NELKEN, David, Comparative Law, Portland, Hart.

. (1994), "The Idea of Juristic Method - A Tribute to Karl Llewellyn, Miami Law Review, Vol. 48, 1993-1994, pp. 119-158.

(1985a), Karl Llewellyn and the Realist Movement, Oklahoma, University of Oklahoma. . (1985b), “Talk About Realism", New York University Law Review, Vol. 60, June/1985, N. 3, pp. 329-384. . (1968), "Two works of Karl Llewellyn - II", The Modern Law Review, Vol. 31, 1968, pp. 165-182.

URUGUAI, Paulino José Soares de Sousa, Visconde do (org. José Murilo de Carvalho). (2002), Ensaio sobre o direito administrativo, São Paulo, Editora 34.

VIANNA, Luiz Werneck (org.). (2003), A Democracia e os três poderes no Brasil. Belo Horizonte/Rio de Janeiro, UFMG/IUPERJ/FAPERJ. . (1976), Liberalismo e Sindicato no Brasil, $2^{\mathrm{a}}$. Ed.,

Rio de Janeiro, Paz e Terra.

VIANNA, Francisco José de Oliveira. (1920), Pequenos estudos de psicologia social, São Paulo, Monteiro Lobato e C. Editores. - (1936), Prefácio ao livro de Luís Pereira dos Santos, Consolidação das Leis Trabalhistas, Rio de Janeiro. (1937a), "Novos métodos de exegese constitucional”, Revista Forense 72 (1937), pp. 5-14. 
. (1937b), "Justiça do Trabalho", Direito Aplicado, vol. 2.

- (1938), Problemas de Direito Corporativo, Rio de Janeiro, José

Olympio.

. (1939), O idealismo da Constituição, Rio de Janeiro, Companhia Editorial Nacional.

. (1943a), Problemas de Direito Sindical, Rio de Janeiro, Max Limonad.

- (1943b), Problemas de Política Objetiva, São Paulo, Companhia

Editora Nacional.

. (1951), Direito do Trabalho e Democracia Social - o problema da incorporação do trabalhador no Estado, Rio de Janeiro/São Paulo, José Olympio.

. (1952), Problemas de Organização e Problemas de Direção, Rio de Janeiro, José Olympio.

. (1956), Evolução do Povo Brasileiro, 4a ed., Rio de Janeiro, José Olympio. . (1973), Populações Meridionais do Brasil, Rio de janeiro, Paz e Terra v.1. (1974), Instituições Políticas Brasileiras, Rio de Janeiro, Record, v.1 e

2. . (1991), “Individualismo e Solidarismo", In Ensaios Inéditos, Campinas, UNICAMP.

VIEIRA, Evaldo. (1981), Autoritarismo e Corporativismo no Brasil, 2a . Ed., São Paulo, Cortez.

VIEIRA, Oscar Vilhena. (2006), Direitos Fundamentais, São Paulo, Melhoramentos. 
(2003), A Moralidade da Constituição e os Limites da Empreitada Constitucional, ou entre Beethoven e Bernstein, in SILVA, Virgílio Afonso da (org.), Intepretação Constitucional, São Paulo, Malheiros.

(2002), Supremo Tribunal Federal: jurisprudência política, 2. ${ }^{a}$ ed., São Paulo, Malheiros.

VILLEY, Michel. (2005), A formação do pensamento jurídico moderno, São Paulo, 2005.

WHITE, G. Edward. (2003), Tort Law in America - An Intellectual History, New York, Oxford University.

WHITE, Morton. (1961), Social Thought in America - The Revolt against Formalism, $3^{\text {a }}$ ed., Boston, Beacon.

ZINN, Howard. (2005), A peoples history of the United States, 5 ed., New York, Harper Perennial.

\section{FONTES DE ÉPOCA}

Archivo Judiciário.

O Direito (Revista de Legislação, Doutrina e Jurisprudência), Rio de Janeiro.

Revista Forense.

Revista dos Tribunais. 


\section{RESUMO}

O objetivo desta dissertação de mestrado é analisar a assimilação "antropofágica"195 do debate jurídico norte-americano produzido em torno da questão social durante a Era Roosevelt por parte do pensamento jurídico brasileiro da Era Vargas. Desse modo, estudar-se-á a forma como os autores norte-americanos da Sociological Jurisprudence e do Realismo Jurídico foram utilizados pela doutrina jurídica brasileira do período entre guerras na formação de um pensamento jurídico antiliberal e anticonceitualista.

No centro da crise do capitalismo mundial, as universidades (Roscoe Pound, 18701964, e Karl Nickerson Llewellyn, 1893-1962), a Suprema Corte (Benjamin Nathan Cardozo, 1870-1938, e Louis Dembitz Brandeis, 1856-1941) e o corpo burocrático do governo (1933-1945) Franklin Delano Roosevelt (1882-1945) (James MacCauley Landis, 1899-1964) produziam alternativas ao mecanicismo judicial e ao modelo liberal. $\mathrm{Na}$ periferia do capitalismo mundial, o corpo burocrático de Vargas (Oliveira Vianna, Francisco Campos e Francisco Sá Filho) e as revistas e debates jurídicos (João Mangabeira e Alípio Silveira) questionavam o liberalismo da República Velha (1889-1930) e buscavam, no mercado global de idéias, modelos institucionais que pudessem ser "antropofagizados", substituindo as "idéias fora do lugar" implantadas pelo bacharelismo utópico da República Velha. Era o momento de explicar o Brasil, encontrar o desenho institucional mais adequado à realidade nacional, construir uma opinião pública e descobrir as soluções para converter o "atraso" em modernização.

Assim, nos principais palcos do debate jurídico dos dois países e, em especial, na Suprema Corte norte-americana e na doutrina jurídica brasileira, percebia-se essa tentativa de revisão do método jurídico, como uma forma de se adequar o direito a um novo quadro de relações do capitalismo industrial. Desse modo, não só se via a necessidade de implantação de um aparato jurídico apto a tratar a questão social (como a regulação das relações do trabalho), como também se observava a necessidade de se reconstruir a forma

\footnotetext{
${ }^{195}$ Utilizarei, nesta dissertação a metáfora da expressão Antopofagia realizada pelo Movimento Modernista basileiro. Assim como os índios canibais devoravam seus inimigos, acreditando que assim assimilavam as suas qualidades, os artistas Modernistas propunham uma "devoração simbólica" da cultura estrangeira, aproveitando suas inovações artísticas sem perder a identidade cultural brasileira.
} 
como se aplicava o direito. O modelo formalista e conceitualista que havia se consolidado sob uma perspectiva privatista e liberal durante o século XIX, mostrava-se ineficiente para atender as novas demandas da sociedade. Esse aspecto de integração entre a questão social e o antiformalismo é essencial para compreender o paralelo entre o pensamento jurídico norte-americano e brasileiro durante o período entre guerras, uma vez que é por meio desse eixo comum que se estabeleceram os principais canais de leitura antropofágica do pensamento jurídico norte-americano pelo pensamento jurídico brasileiro. 


\section{ABSTRACT}

The objective of this Master's Degree dissertation is to analyze the "anthropophagical"196 assimilation of the North-American legal debate, arising from the social issue during the Age of Roosevelt, by the Brazilian legal thought of the Age of Vargas. Therefore, one will study the way how the North-American authors of the Sociological Jurisprudence and of the Legal Realism have been used by the Brazilian legal doctrine of the interwar period, in the formation of an anti-liberal and anti-conceptualist legal thought.

In the core crisis of the worldwide capitalism, Universities (Roscoe Pound, 18701964, and Karl Nickerson Llewellyn, 1893-1962), Supreme Court (Benjamin Nathan Cardozo, 1870-1938, and Louis Dembitz Brandeis, 1856-1941) and bureaucratic body of the Franklin Delano Roosevelt (1882-1945) government (1933-1945) (James MacCauley Landis, 1899-1964) produced alternatives to the legal mechanicism and to the liberal model. At the periphery of the world capitalism, the bureaucratic body of Vargas (Oliveira Vianna, Francisco Campos and Francisco Sá Filho) and the legal magazines and debates (João Mangabeira e Alípio Silveira) questioned the liberalism of the Old Republic (18891930) and searched, in the global market of ideas, for institutional models that could be "anthropophagized", replacing the "out-of-place ideas" implemented by the utopic bachelorism of the Old Republic. That was the time of explaining Brazil, finding the institutional drawing that is the most proper to the national reality, building a public opinion and discovering the solutions to convert the "delay" into modernization.

Thus, in the main background legal debate of the two countries' legal debate, and especially in the United States Supreme Court and in the Brazilian legal doctrine could be perceive such attempt of review of the legal method, as a way of fitting the law to a new picture of relations of the industrial capitalism. Therefore, it would be seen not only the need of implementation of a legal apparatus proper to treat the social issue (such as the

${ }^{196}$ I will use, in this dissertation, the metaphor of the word Anthropophagy made by the Brazilian Modernist Movement. Like the cannibal Indians used to devour their enemies, with the belief that, as such, they would assimilate their qualities, the Modernist artists used to propose a "symbolic devouring" of the foreign culture, taking advantage of their artistic innovations without losing the Brazilian cultural identity. 
regulation of the work relations), as well as one would observe the need of rebuilding the way how the law was applied. The formalist and conceptualist model that would be consolidated under a privativistic and liberal perspective during the 19th Century showed to be ineffective to deal with the new demands of the society. This aspect of integration between the social issue and the anti-formalism is essential to understand the parallel between the North-American and Brazilian legal thought during the interwar period, since the main channels of anthropophagic reading of the North-American legal thought by the Brazilian one have been established by means of this common axis. 